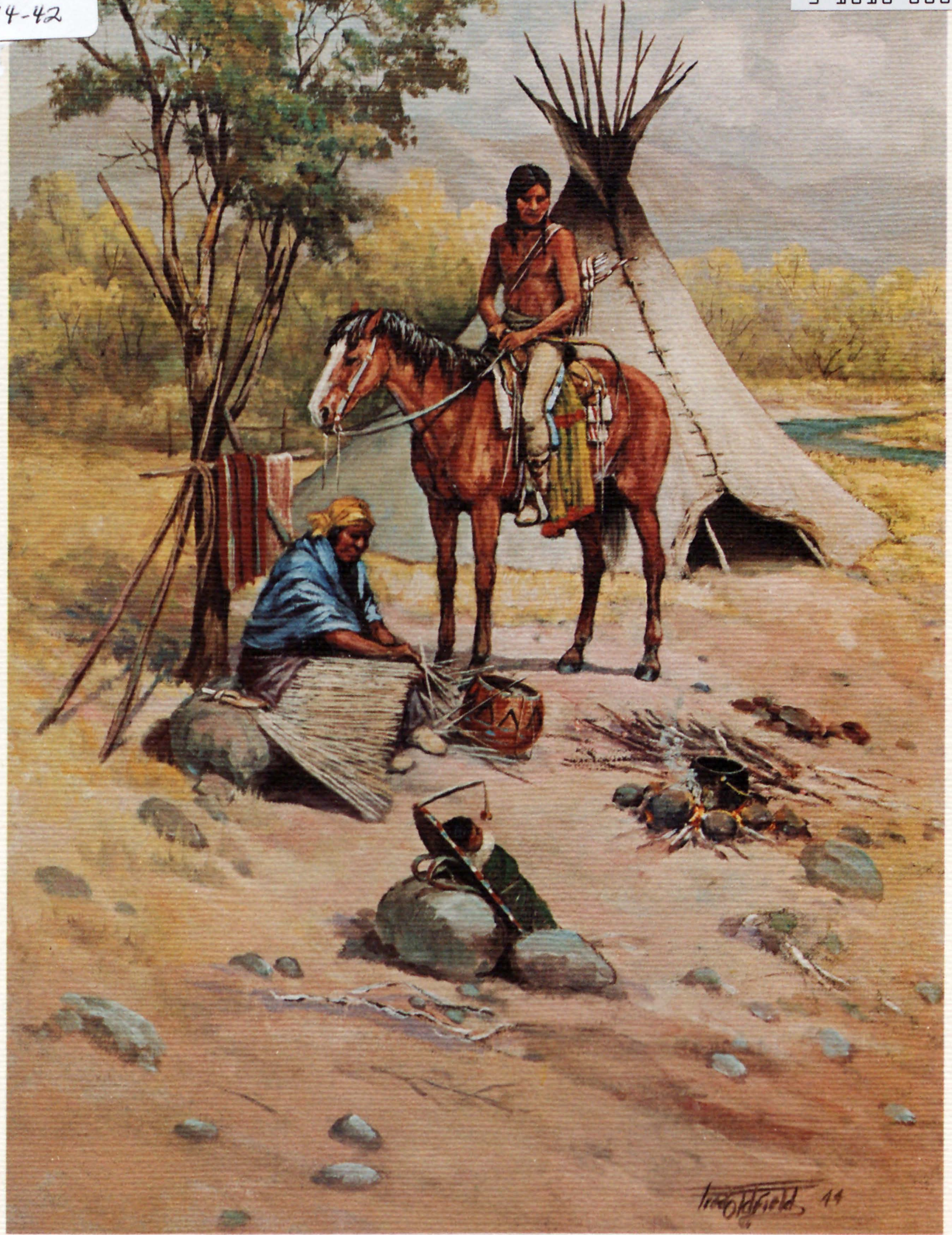

\title{
WATER RESOURCES OF THE TOPPENISH CREEK BASIN YAKIMA INDIAN RESERVATION, WASHINGTON
}

U.S. GEOLOGICAL SURVEY

Water-Resources Investigations $42 \cdot 74$ 
WATER RESOURCES OF THE TOPPENISH CREEK BASIN, YAKIMA INDIAN RESERVATION, WASHINGTON

U.S. GEOLOGICAL SURVEY

Water-Resources Investigations 42-74

Prepared in cooperation with the Yakima Tribal Council

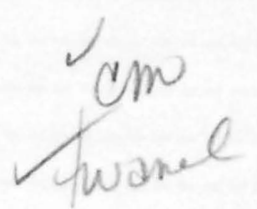




\title{
UNITED STATES DEPARTMENT OF THE INTERIOR \\ Rogers C. B. Morton, Secretary
}

GEOLOGICAL SURVEY

V. E. McKelvey, Director

\author{
Cover Painting By Fred Oldfield \\ Covers Furnished by Yakima Tribal Council
}

For additional information write to:

U.S. Department of the Interior

Geological Survey

Water Resources Division

1305 Tacoma Avenue

Tacoma, Washington 98402 
Abstract-

Introduction-....... 4

Location and extent of the basin-..- 5

Purpose and scope-- 7

Previous studies-- 7

Acknowledgments-... 8

Well- and spring-numbering system-_... 9

The hydrologic environment- 10

Climate and precipitation-- 10

Geology and physiography 10

Surface-water resources-_... 13

Available surface-water data-................... 14

Streamflow characteristics-_. 17

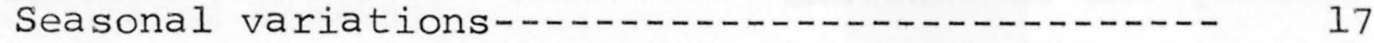

Areal variations-_...... 19

Flow duration-... 21

Frequency of low flows-...... 23

Floods-........ 26

Surface-water irrigation-.... 28

Development and diversions-................ 28

Inflow and outflow of irrigation water-..-..- 32

Ground-water resources-_... 33

Data availability and methods of analysis-.-.-.-.-. 33

Young valley fill-... 37

Aquifer characteristics-_... 37

Water levels...... 40

Recharge to the aquifer-........ 44

Discharge from the aquifer-....... 47

Present ground-water development-..-...- 50

Potential for further development--.-.-.- 50

Old valley fill-...-...... 52

Aquifer characteristics-_...- 52

Water levels-... 53

Recharge to the aquifer................. 53

Discharge from the aquifer-....... 58

Present ground-water development-_.-.-..-.-. 58

Potential for further development-..... 59

Basalt_.............. 59

Aquifer characteristics-_-........-. 60

Water levels..... 62 
Ground-water resources--Continued

Basalt--Continued

Page

Recharge to the aquifer.

Discharge from the aquifer-...

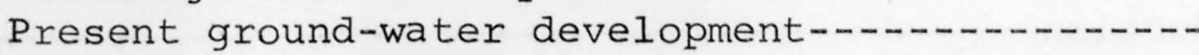

Potential for further development

68

70

70

71
75

75

77

77

78

78

79

79

79

79

81

82

85

Appendix I. Reduced copies of U.S. Geological Survey 7.5-minute topographic quadrangles, showing areas largely inundated by the flood of January 1974 in the Toppenish

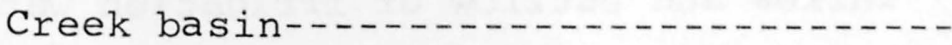

II. Monthly and annual surface-water discharges at selected sites in the Toppenish Creek basin as shown in figure 4 and listed in table 1......

III. Records of selected wells in the

Toppenish Creek basin-.................

IV. Logs of selected wells in the Toppenish

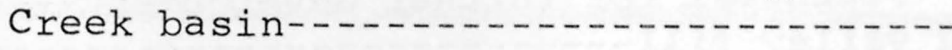




\section{ILLUSTRATIONS}

Page

FIGURE 1. Map of Toppenish Creek basin, showing topo-

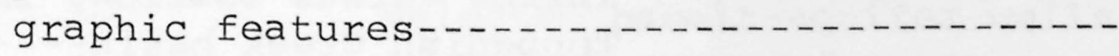

2. Map of Toppenish Creek basin, showing average annual precipitation....................

3. Graph showing percentage monthly of average annual precipitation-..................-

4. Map of Toppenish Creek basin, showing surfacewater data-collection sites-......-.-.--

5. Hydrograph of daily flows of North Fork Simcoe Creek near Fort Simcoe, and daily temperature extremes and daily precipitation at Rimrock Tieton Dam for 1971............

6-13. Graphs showing:

6. Average monthly precipitation and average monthly runoff at selected stations, Oct. 1, 1970-Sept. 30, $1972 \ldots \ldots \ldots$

7. Flow-duration curves for Toppenish Creek near Fort Simcoe and Simcoe Creek below Spring Creek, near Fort Simcoe-........................

8. Low-flow-frequency curves for Toppenish Creek near Fort Simcoe-......-

9. Low-flow-frequency curves for Simcoe Creek below Spring Creek, near Fort Simcoe-....................

10. Annual flood-frequency curves for Toppenish Creek near White Swan, near Fort Simcoe, and for Simcoe Creek below Spring Creek, near Fort

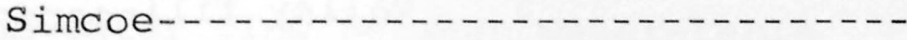

11. Annual diversion from the Yakima

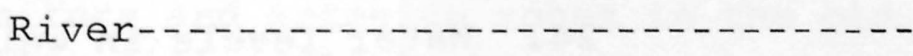

12. Annual diversions from Toppenish and Simcoe Creeks.................... 
FIGURES 6-13. Graphs showing--Continued

13. Accumulated total surface-water inflow versus outflow, in the Toppenish Creek basin-.....-.

14-17. Maps of Toppenish Creek basin showing:

14. Locations of selected wells, seepage-data sites, and areas of various groups of wells tapping the basalt aquifer----

15. Hydrogeologic units-........ 35

16. Schematic logs of selected wells in the young and old valley fills_.................... 38

17. Contours of average water-table altitudes in wells tapping unconfined aquifers in the young and old valley fills----

18. Graphs showing seasonal water-level changes in the young valley fill......

19-25. Maps of Toppenish Creek basin showing:

19. Annual range in water-table fluctuations in the young and old valley fill..................

20. Generalized differences between heads in the artesian zones of the old valley fill and average water-table contours--

21. Water levels in artesian zones in the old valley fill.......

22. Head differences between aquifers in the basalt and the old valley fill................

23. Contours of the basalt surface---

24. Water levels in wells tapping basalt aquifers.............

25. Decline of water levels in wells in the basalt aquifer........ 
FIGURES 26-29. Graphs showing:

26. Relationship of water levels in selected basalt-aquifer wells to annual rates of pumpage-.-- 66

27. Seasonal water-level fluctuations in basalt-aquifer wells-.-.-.--

28. Relationship of potential evapotranspiration to land-surface

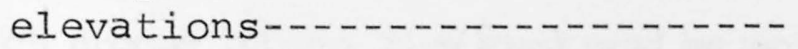

29. Average annual drawdown by groups of wells in the basalt aquifer-

30. Nomograph for projecting average annual water-level declines in basalt-aquifer

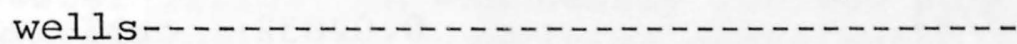

31. Graph showing relationship between average pumping cost and pumping lift-..--.-- 74

32. Schematic hydrologic budget of the Toppen-

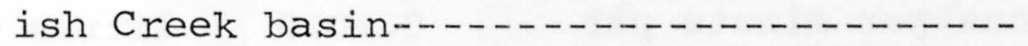

\section{TABLES}

TABLE 1. Periods of surface-water data collection at sites in the Toppenish Creek basin as shown in figure 4.................. 16

2. Stratigraphic relationships and hydrologic characteristics of the geologic units in the Toppenish Creek basin........ 36

3. A comparison of types of wells constructed in the young valley fill...........

4. Ground-water flow between water-table zones in the young and old valley fill aquifers and artesian zones in the old valley fill aquifer, by areas--------- 48

5. Ground-water flow between the old valley fill and basalt aquifers, by areas--.--- 
In recognition of a worldwide trend to adoption of the metric system of measurements (SI or System Internationale), the following factors are provided for conversion of English values used in this report to metric values:

\begin{tabular}{|c|c|c|}
\hline Multiply & By & To obtain \\
\hline Inches & $\begin{array}{l}25.4 \\
2.54 \\
0.0254\end{array}$ & $\begin{array}{l}\text { millimetres }(\mathrm{mm}) \\
\text { centimetres }(\mathrm{cm}) \\
\text { metres }(\mathrm{m})\end{array}$ \\
\hline Feet $(\mathrm{ft})$ & 0.3048 & metres $(\mathrm{m})$ \\
\hline Miles (mi) & 1.609 & kilometres $(\mathrm{km})$ \\
\hline Square miles $\left(\mathrm{mi}^{2}\right)$ & 2.590 & square kilometres $\left(\mathrm{km}^{2}\right)$ \\
\hline Acres & 4047 . & square metres $\left(\mathrm{m}^{2}\right)$ \\
\hline Acre-feet (acre-ft) & 1233. & cubic metres $\left(\mathrm{m}^{3}\right)$ \\
\hline $\begin{array}{l}\text { Cubic feet per second } \\
\left(\mathrm{ft} \mathrm{t}^{3 / \mathrm{s})}\right.\end{array}$ & $\begin{array}{l}28.32 \\
0.02832\end{array}$ & $\begin{array}{l}\text { litres per second }(1 / \mathrm{s}) \\
\text { cubic metres per second } \\
\left(\mathrm{m}^{3} / \mathrm{s}\right)\end{array}$ \\
\hline $\begin{array}{l}\text { Gallons per minute } \\
\text { (gal/min) }\end{array}$ & 0.06309 & litres per second $(1 / \mathrm{s})$ \\
\hline $\begin{array}{l}\text { Gallons per minute per } \\
\text { foot }[(\mathrm{gal} / \mathrm{min}) / \mathrm{ft}]\end{array}$ & 0.2070 & $\begin{array}{l}\text { litres per second per } \\
\text { metre }[(1 / \mathrm{s}) / \mathrm{m}]\end{array}$ \\
\hline Feet per second $(\mathrm{ft} / \mathrm{s})$ & 0.3048 & metres per second $(\mathrm{m} / \mathrm{s})$ \\
\hline $\begin{array}{l}\text { Feet squared per day } \\
(\mathrm{ft} 2 / \mathrm{d})\end{array}$ & 0.0929 & $\begin{array}{l}\text { metres squared per day } \\
\left(\mathrm{m}^{2} / \mathrm{d}\right)\end{array}$ \\
\hline $\begin{array}{l}\text { Feet per second per } \\
\text { square foot }\left[(\mathrm{ft} / \mathrm{s}) / \mathrm{ft}^{2}\right]\end{array}$ & 0.3048 & $\begin{array}{l}\text { metres per second per } \\
\text { square metre }\left[(\mathrm{m} / \mathrm{s}) / \mathrm{m}^{2}\right]\end{array}$ \\
\hline $\begin{array}{l}\text { Pounds per square inch } \\
\text { (1bs/in })\end{array}$ & 0.07031 & $\begin{array}{l}\text { kilograms per square } \\
\text { centimetres }\left(\mathrm{kg} / \mathrm{cm}^{2}\right)\end{array}$ \\
\hline
\end{tabular}


WATER RESOURCES OF THE TOPPENISH CREEK BASIN, YAKIMA INDIAN RESERVATION, WASHINGTON

\section{ABSTRACT}

The Yakima River, which flows along the eastern margin of the Yakima Indian Reservation, provides about 93 percent of the irrigation water for the eastern part of the Toppenish Creek basin--the major agricultural area in the basin. During 1972, the total surface water diverted from all streams and from ground-water irrigation was nearly 700,000 acre-feet (863 million cubic metres); the quantities contributed from each source are as follows:

\begin{tabular}{|c|c|c|}
\hline Source & $\begin{array}{l}\text { Thousands } \\
\text { of } \\
\text { acre-feet }\end{array}$ & $\begin{array}{l}\text { Percent } \\
\text { of } \\
\text { total }\end{array}$ \\
\hline $\begin{array}{l}\text { Surface water: } \\
\text { Yakima River: } \\
\text { (a) Main Canal } \\
\text { (b) Wanity Slough }\end{array}$ & $\begin{array}{r}647.2 \\
8.4\end{array}$ & $\begin{array}{r}92.5 \\
1.2\end{array}$ \\
\hline $\begin{array}{l}\text { Toppenish Creek via } \\
\text { Toppenish Feeder Canal- } \\
\text { Simcoe Creek via Simcoe } \\
\text { Creek flume- }\end{array}$ & 19.8 & 2.8 \\
\hline $\begin{array}{l}\text { Ground water: } \\
\text { (a) from wells in the basalt } \\
\text { (b) from wells in the valley } \\
\text { fill } \\
\text { Total (rounded) }\end{array}$ & $\begin{array}{r}17.5 \\
3.5 \\
700.0\end{array}$ & $\frac{2.5}{100.0}$ \\
\hline
\end{tabular}


The streams in the uplands of the basin have greatly variable flows throughout the year. Flow-duration curves for gaging stations on Toppenish Creek near Fort Simcoe and Simcoe Creek below Spring Creek, near Fort Simcoe, show that at the Toppenish Creek station streamflow was equal to or greater than 16 cubic feet per second ( 0.45 cubic metres per second) 90 percent of the time during 1944-72, and the flow of Simcoe Creek was 1.3 cubic feet per second ( 0.037 cubic metres per second) or greater 90 percent of the time for the same period. Present diversions from the Yakima River and from Toppenish Creek and its tributaries provide an excess of about 465, 000 acre-feet (573 million cubic metres) of water that leave the basin each year.

The Toppenish Creek basin has three major aquifers: the basalt aquifers, which overlies the entire basin; the old valley fill, which overlies the basalt in the lower parts of the basin; and the young valley fill, which overlies the old valley fill in the eastern parts of the basin. Each aquifer is capable of yielding more than 1,000 gallons per minute (63 litres per second) to individual wells that are open to significant thicknesses of saturated aquifer material. Specific capacities of wells in the young valley fill range from about 2 to 58 gallons per minute per foot (0.4 to 12 litres per second per metre) of drawdown and average about 10 gallons per minute per foot (2.1 litres per second per metre) of drawdown.

During the period 1910-31 about 1.3 million acre-feet ( 1.6 billion cubic metres) of water entered into storage in the young valley fill. Although the annual-high water levels in the young valley fill have not changed significantly in recent years, there are considerable areal variations in the amplitude of annual water levels. Present (1974) pumpage from this aquifer is about 6,000 acre-feet $(7.4$ million cubic metres) per year, but as much as 120,000 acre-feet (150 million cubic metres) per year could be pumped. Properly constructed wells could pump about 1,350 gallons per minute (85 litres per second) with about 30 feet ( 9.1 metres) of drawdown. With minimum spacing of about 0.5 mile ( $0.8 \mathrm{kilometre})$ they should have minimal interference.

The old valley fill is composed primarily of sedimentary deposits of the Ellensburg Formation. The distribution of the components of this unit differs widely both vertically and horizontally. Where the aquifer is within 50 feet 
(15 metres) of the land surface the upper part of the aquifer is under water-table conditions, whereas water in deeper zones is under artesian pressure. Specific capacities range from about 3 to 300 gallons per minute per foot $(0.6$ to 60 litres per second) of drawdown. There have been some declines in the heads in the artesian zones of this aquifer within the last 1.5 years, most likely due to the pumping from the underlying basalt aquifer. The old valley fill yields approximately 6,500 acre-feet ( 8 million cubic metres) per year to wells in the basin. Currently, an estimated 10,000 acre-feet (12 million cubic metres) of water per year is discharged from this aquifer as underflow beneath the southeastern corner of the basin; a large part of this discharge could be developed by wells.

Yields of wells tapping the basalt range from about 45 to 2,200 gallons per minute (2.8 to 140 litres per second), with specific capacities ranging from less than 1 to 400 gallons per minute per foot ( 0.2 to 83 litres per second per metre) of drawdown and averaging about 16 gallons per minute per foot ( 3.3 litres per second per metre) of drawdown. Water levels have declined substantially since the mid-1950's because of increased development of irrigation water from wells tapping the aquifer. About 1,400 acre-feet ( 1.7 million cubic metres) has been lost from storage; this is less than 1 percent of the total water pumped from the basalt. As much as 118,000 acre-feet (145 million cubic metres) of water may enter the basalt aquifer each year from recharge in the mountainous western highlands and from the overlying old valley fill. Present (1974) ground-water pumpage from the basalt aquifer totals about 16,000 acre-feet ( 20 million cubic metres) per year. However, this pumpage is inequitably distributed, and water-level declines in excess of 100 feet (30 metres) have occurred in some of the more heavily pumped areas. The potential for increased future pumpage from the aquifer and the probable impact of that pumpage on the heads in the basalt is presented in this report. Near Ahtanum and Toppenish Ridges the development of large withdrawals will result in large drawdowns. In Medicine Valley and in the remainder of the western lowland, expanded development will not result in drawdowns as great as near the ridges. In the eastern part of the lowlands the basalt aquifer has not been tapped. In the southeastern part of the valley, where the potentiometric surface may be as much as 150 feet (46 metres) above land surface, the basalt aquifer offers a potential for additional large supplies of water. 
An annual water budget of the basin shows an input of about 683,000 acre-feet ( 842 million cubic metres) to the basin from precipitation and about 651,000 acre-feet (802 million cubic metres) from diversions from the Yakima River. Ajout 719,000 acre-feet ( 887 million cubic metres) of the total is consumed by evapotranspiration, and the remainder drains back into the Yakima River, except for a small quantity of ground water that flows eastward beneath the river. Changes in management of the hydrologic system in the basin would allow capture of some or even most of the ground-water outflow.

\section{INTRODUCT ION}

The Toppenish Creek basin of the Yakima Indian Reservation is on the eastern slope of the Cascade Range. The mountains form a partial barrier to the eastward movement of moistureladen air from the Pacific Ocean, and, as a result, most of the basin has a semiarid climate. Owing to the dry climate, agricultural development of the abundant arable soils in the basin relies heavily on irrigation for crop production. Sufficient water is available for present needs, with about 651,000 acre-feet ( 802 million cubic metres) being diverted annually from the Yakima River, about 22,000 acre-feet (27 million cubic metres) from Toppenish Creek and its tributaries, and about 27,000 acre-feet ( 33 million cubic metres) from ground-water sources. Although sufficient water is generally available for the basin there are problems of distribution and supply within the basin; overpumping of basalt aquifers has produced a marked decline in the hydraulic heads in some areas and has also produced interference between large irrigation wells. Increasing demands for water supplies, plans for irrigating new lands, ground-water problems, and proposals to divert from the Yakima River by water users downstream from the reservation have made an accounting of water availability very important for present-day water management in the basin. The Tribal Council of the Yakima Indian Nation entered into a cooperative study with the U.S. Geological Survey to determine the general amount of water available and to provide information to aid the Tribe in the regulation, management, and protection of this resource.

This report summarizes the results of the study and presents technical information on the water resources of the basin for hydrologists, engineers, planners, and water managers who need 
this knowledge to guide their endeavors. A brief lay-reader report describing this study is also in preparation for those who may be interested in the general findings and highlights of the investigation without the detail and data compilations contained in this report.

Similar studies are also being conducted on the water resources of the Satus Creek and Klickitat River basins, the two other major drainages of the Yakima Indian Reservation.

\section{Location and Extent of the Basin}

The Toppenish Creek basin is the northernmost of three major river basins in the Yakima Indian Reservation. The basin has a drainage area of $627 \mathrm{mi}^{2}\left(1,620 \mathrm{~km}^{2}\right)$ in Yakima County of south-central Washington (fig. 1). With its western one-third forming an upland plateau along the eastern flanks of the Cascade Range. The Toppenish Creek basin descends to the east, from about $5,000 \mathrm{ft}(1,520 \mathrm{~m})$ above mean sea level to about $1,000 \mathrm{ft}(300 \mathrm{~m})$ in the first $15 \mathrm{mi}(24 \mathrm{~km})$. In the remaining $21 \mathrm{mi}(34 \mathrm{~km})$ to its eastern border at the Yakima River, the basin descends another $270 \mathrm{ft}(82 \mathrm{~m})$ eastward, between Ahtanum Ridge on the north and Toppenish Ridge on the south. 


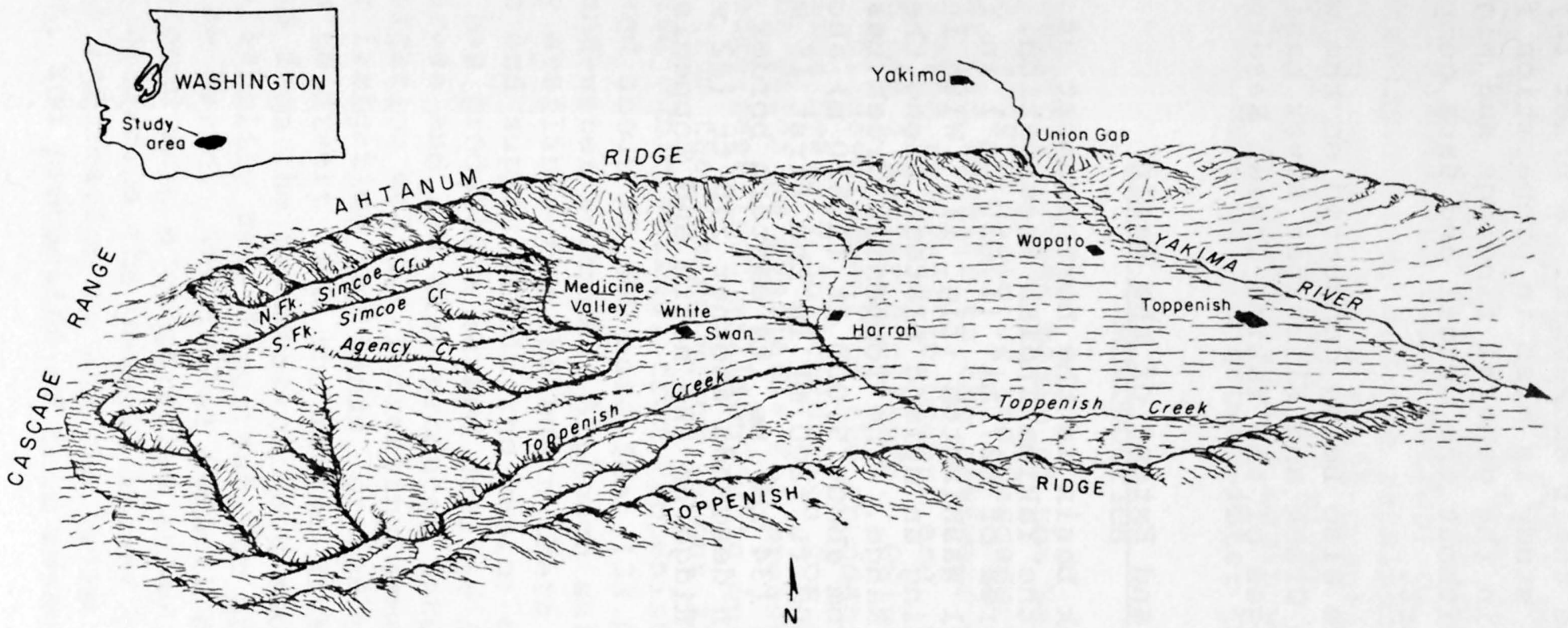

FIGURE 1.--Oblique-view sketch of major topographic features in Toppenish Creek basin. 


\section{Purpose and Scope}

Toppenish Creek basin is an agricultural area whose productivity is dependent on irrigation. To develop plans for the regulation and management of the basin's water resources, the Yakima Indian Nation needs basic information on the following aspects of the hydrology of the basin:

1. The seasonal and areal distribution of natural streamflow.

2. The location and extent of geologic units relative to their capacity to store and yield water.

3. The degree to which the surface- and ground-water systems are interrelated.

4. The effects of the present and potential development on the hydrologic system.

This report compiles available data on surface and ground water in the Toppenish Creek basin and provides interpretations to satisfy the foregoing objectives.

\section{Previous Studies}

Many geologic studies have been made in and adjacent to the Yakima Indian Reservation since the earliest report by Russell (1893). Other early geologic reports covering central Washington are by Smith (1901, 1903) and Waring (1913). These reports discussed the general occurrence of ground water and described some of the earliest wells in the region.

More recent studies that include the reservation lands deal almost exclusively with the geology, and the resulting reports differ considerably in emphasis. Few intensive studies concerned principally with the water resources, such as that of the Ahtanum Valley by Foxworthy (1962), have been made in areas on or adjacent to the reservation. Kinnison and Sceva (1963) utilized limited gaging-station records of tributary streams in the Yakima Reservation in their study of streamflow records of the Yakima River. Numerous unpublished reports and administrative letters concerned with well-site appraisals, damsite proposals, drainage problems, and incomplete well inventories have been made since the late 1950's. Data and results of these earlier studies have been used where applicable in this study. 


\section{Acknowledgments}

The U.S. Geological Survey is indebted to present and former personnel of the U.S. Bureau of Indian Affairs (BIA) for their considerable help in coding well forms, measuring water levels in wells, servicing water-stage recorders, and many other services. Appreciation is gratefully extended to Dick Anderson of the Yakima Agency Staff of BIA for the data and assistance provided and to Judd Allsop, Project Engineer, and J. B. Caruthers of the Wapato Irrigation Project Office of BIA, for providing data on the project's surface-water diversions. The cooperation of G. D. Black and H. L. Sexton of the Fort Simcoe Job Corps Center in installing gaging stations and servicing the Agency Creek gaging station is acknowledged. Special thanks are due the many well owners, including the cities of Wapato and Toppenish, for permitting their wells to be measured or tested. Without their cooperation this study would have been much more limited in scope.

D. O. Gregg and R. J. Burt collected the ground-water and geologic data and prepared the water-level-contour maps for this report, E. G. Nassar collected the surface-water data and performed most of the analyses of these data, and R. D. Mac Nish and G. G. Parker, Jr., prepared the report. Technical review of the manuscript by B. L. Foxworthy and H. H. Tanaka of the U.S. Geological Survey enhanced the final report. 


\section{WELL- AND SPRING-NUMBERING SYSTEM}

In this report wells and springs are designated by symbols that indicate their locations according to the official rectangular public land survey. For example, in the well symbol 10/20-3Ml, the part preceding the hyphen indicates successively the township and range (T.10 N., R.20 E.) north and east of the Willamette base line and meridian. Because the report area lies entirely north and east of the base Iine and meridian, the letters indicating the directions north and east are omitted, except in the computer printout of well records (appendix III, end of report). The first number following the hyphen indicates the section (sec.3), and the letter "M" gives the 40-acre $\left(162,000 \mathrm{~m}^{2}\right)$ subdivision of the section, as shown in the diagram below. The numeral " 1 " indicates that this well is the first one listed within subdivision "M."

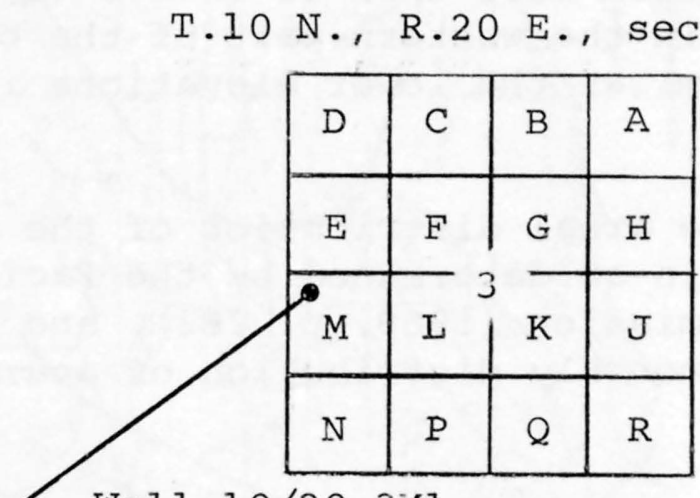

Well 10/20-3i1

As listed in appendix III, which is a computer printout of selected wells in the study area, this well is designated by the number loN20E03M0l. In the table, the wells are also given numbers designating their latitude and longitude locations. 


\section{THE HYDROLOGIC ENVIRONMENT}

The hydrologic environment is controlled naturally mainly by climate, slope and shape of the land surface, and the types of rock materials that occur beneath the land. Below are discussed these various characteristics--and the activities of man--as they apply to the water resources of the Toppenish Creek basin.

\section{Climate and Precipitation}

Hot, dry summers and cold, dry winters characterize the climate in the Toppenish Creek basin. Daytime temperatures generally range from $25^{\circ}$ to $40^{\circ} \mathrm{F}\left(-4.0^{\circ}\right.$ to $\left.4.5^{\circ} \mathrm{C}\right)$ in winter to $75^{\circ}$ to $95^{\circ} \mathrm{F}\left(24^{\circ}\right.$ to $\left.35^{\circ} \mathrm{C}\right)$ in summer. Because the basin lies in the rain shadow of the Cascade Range, the annual precipitation ranges from more than 50 inches $(1,270 \mathrm{~mm})$ at the higher elevations in the western part of the basin to about 7 inches $(178 \mathrm{~mm})$ at the lower elevations in the eastern part.

Figure 2 shows the areal distribution of the annual precipitation in the basin as determined by the Pacific Northwest River Basins Commission (1969, p. 282), and figure 3 shows the percentage monthly distribution of average annual precipitation.

\section{Geology and Physiography}

The Toppenish Creek basin is the western half of an eastwest oval-shaped geologic trough formed by folded basaltic rocks and is partially filled with unconsolidated sediments ranging from clay to coarse gravel. The major physiographic features of the basin are shown in figure 1 .

The geologic origin of the basin can be traced back about 20 million years to the Miocene Epoch. At that time, what is now central Washington was a large plain extending from the present position of the Cascade Range eastward into Idaho and southward into Oregon. The plain resulted from millions of years of fissure-type eruptions of basaltic lavas that today make up the Yakima Basalt of the Columbia River Group. Near the end of the volcanic activity, the area was deformed by compression and the basalt flows were folded into ridges 


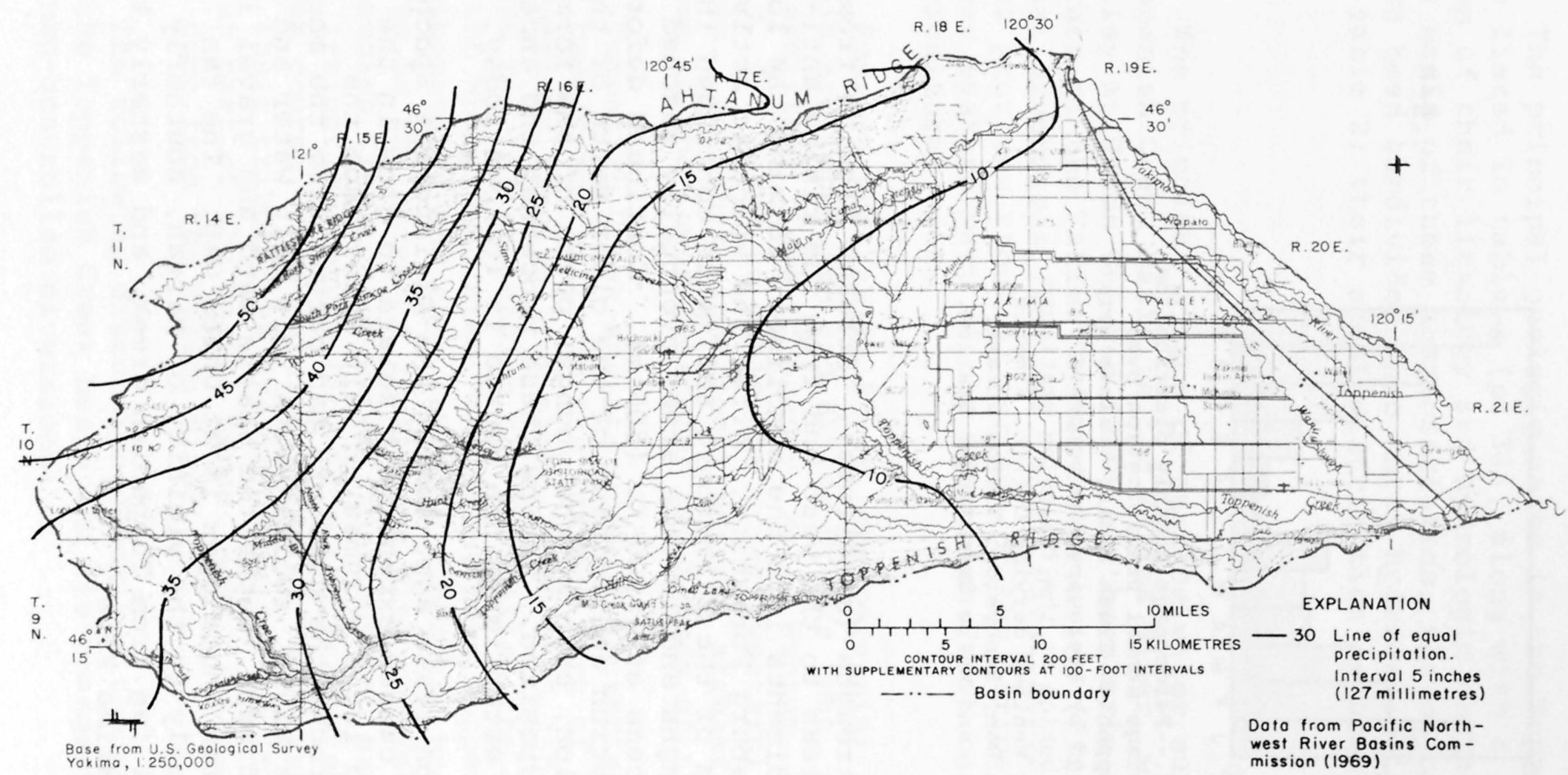

FIGURE 2.--Average annual precipitation in the Toppenish Creek basin. 


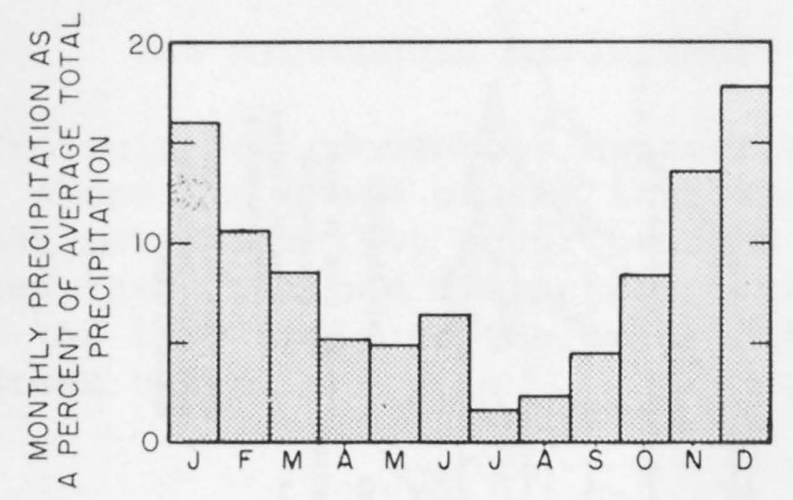

FIGURE 3.--Percentage monthly distribution of average annual precipitation over the Toppenish Creek basin. Values were obtained by averaging the percentage distribution at the following stations: Yakima Weather Service Office, Rimrock Tieton Dam, Sunnyside, Tieton Intake, Wapato, and White Swan Ranger Station.

(anticlines) and troughs (synclines). Streams flowing from the mountainous areas to the west and from the rising anticlines carried sediments into the synclines, forming the lower part of the Ellensburg Formation. After the volcanic activity ceased, deposition of the Ellensburg sediments continued in the deepening troughs and in some areas eventually reached thicknesses in excess of $1,000 \mathrm{ft}(300 \mathrm{~m})$. Continued deformation caused disruption and folding of the older parts of the Ellensburg Formation, even as the younger parts of the formation were being deposited. During these processes the ancestral Yakima River established the course it follows today.

About 1 million years ago, during the Pleistocene Epoch, a cooling climate caused extensive glaciers to grow in the Cascade Range, and large volumes of melt water from the glaciers carried rocks the glaciers had carved from the mountains. The Yakima River, swollen with this melt water and overladen with sediment, deposited coarse sand and gravel in a broad alluvial fan whose apex is at Union Gap. The fan extends southwesterly to the vicinity of Harrah, southerly to a similar alluvial fan from Toppenish Creek, and easterly to the present-day Yakima River. 
The principal geologic units in the Toppenish Creek basin are listed in table 2 ( $p .36$ ), along with a general summarization of their lithology and hydrologic characteristics. On the basis of these characteristics, the major geologic units have been subdivided into three hydrogeologic units as listed in table 2; their areal distribution is shown in figure 15.

\section{SURFACE-WATER RESOURCES}

The principal source of surface water supplying the Toppenish Creek basin is the Yakima River, which enters the valley at Union Gap and flows southeasterly along the eastern margin of the Yakima Indian Reservation (fig. 1). Gravitycanal diversions from the Yakima River supply a ditch system that provides about 93 percent of the irrigation water for the lower eastern part of the Toppenish Creek basin--its major agricultural area.

Besides the Yakima River, the perennial streams in the basin are Toppenish and Simcoe Creeks that, combined with the intermittent flows of Agency, Mill, Wahtum, and Hunt Creeks (fig. 4), serve to drain the upper (western) one-third of the basin. No other significant natural streamflow enters Toppenish Creek in the lower (eastern) two-thirds of the basin.

Toppenish Creek and its upper tributaries originate in the basalt foothills in the western part of the basin, at elevations ranging from about 3,500 to $5,250 \mathrm{ft}(1,070$ to $1,600 \mathrm{~m})$. After leaving the foothills, the streams converge in the White Swan area, and from there Toppenish Creek flows southeasterly and then easterly along the base of Toppenish Ridge to the stream's confluence with the Yakima River. Toppenish Creek gains water from abundant ground-water seepage and irrigation return flow from the irrigated areas along its lower course. The natural flows of Toppenish and Simcoe Creeks and their tributaries are insufficient to irrigate most of the lower part of the basin; hence, most of the irrigation water has come from the Yakima River.

The following discussion describes the natural streamflow in the Toppenish Creek basin and the changes in flow caused by man-controlled diversions. 


\section{Available Surface-Water Data}

Basic data of varying lengths of record and quality are available for streamflow gaging sites in the Toppenish Creek basin. Figure 4 shows the locations of some of the sites and indicates the type of data collected. Table 1 lists the sites by downstream order number, and the periods of record for each site are shown by bars. For those sites to which no downstream order number has been assigned, the sites are alphabetically coded. Appendix II (end of report) lists monthly and annual discharge data for many of the sites for entire periods of record.

By use of a computer statistical-analysis program the long-term gaging-station record for the Toppenish Creek site (12506000) was used to extend the shorter term record for the gaging station on Simcoe Creek (12506500). These two stations provide the nucleus for evaluating the natural streamflow characteristics of the basin. For supplemental streamflow data on smaller tributary streams flowing directly from the uplands, four gaging stations were operated at the following numbered sites (shown in fig. 4):

\section{North Fork Simcoe Creek near Fort Simcoe 12506330. South Fork Simcoe Creek near Fort Simcoe 12506600. Agency Creek near Fort Simcoe 12507100. Mill Creek near White Swan}

As shown in figure 4, three crest-stage gages also were operated in the basin to record peak flood stages in small drainage areas. 


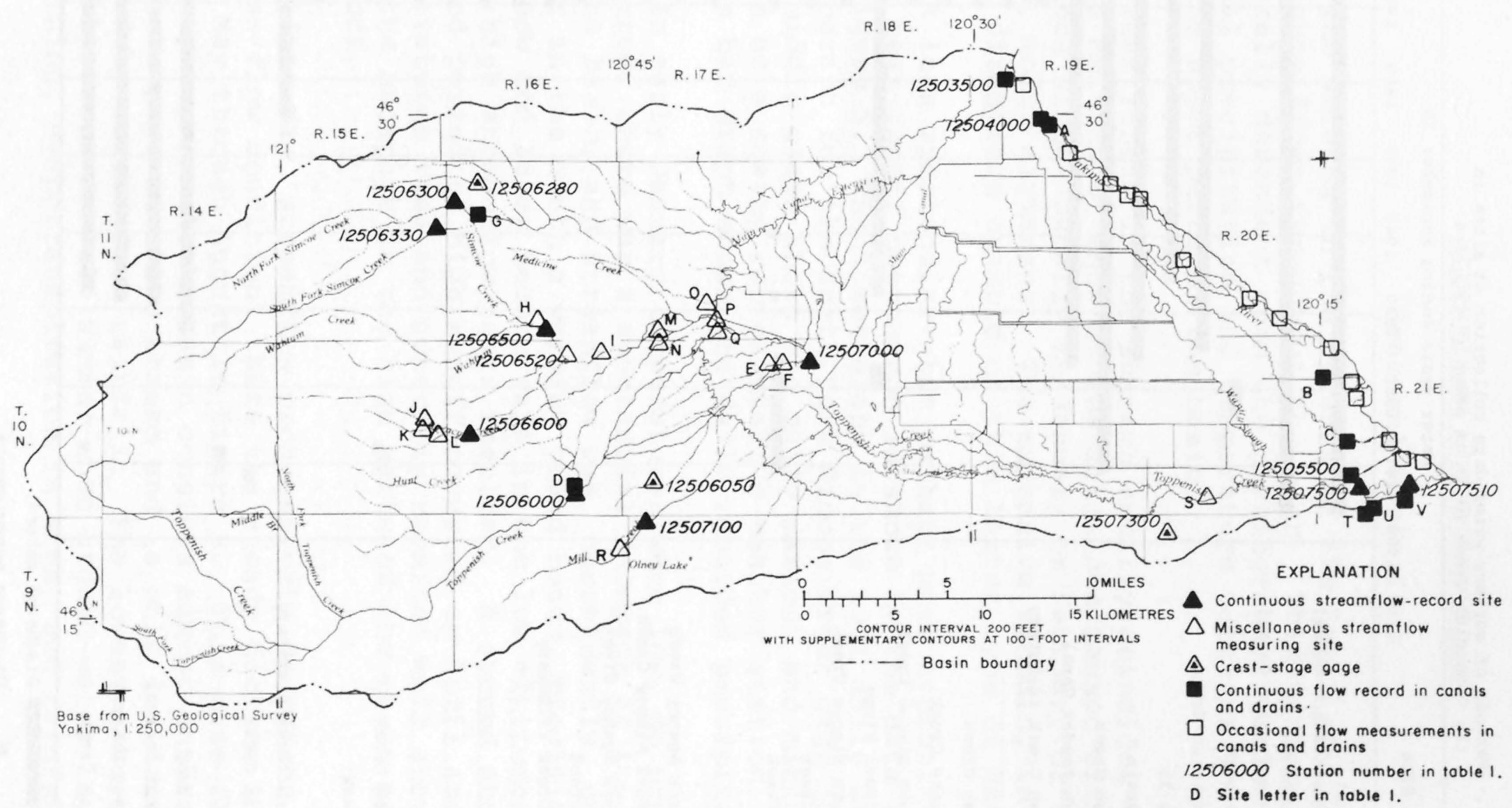

FIGURE 4.--Locations of surface-water data-collection sites in the Toppenish Creek basin. 
TABLE 1.--Periods of surface-water data collection at sites in the Toppenish Creek basin as shown in figure 4

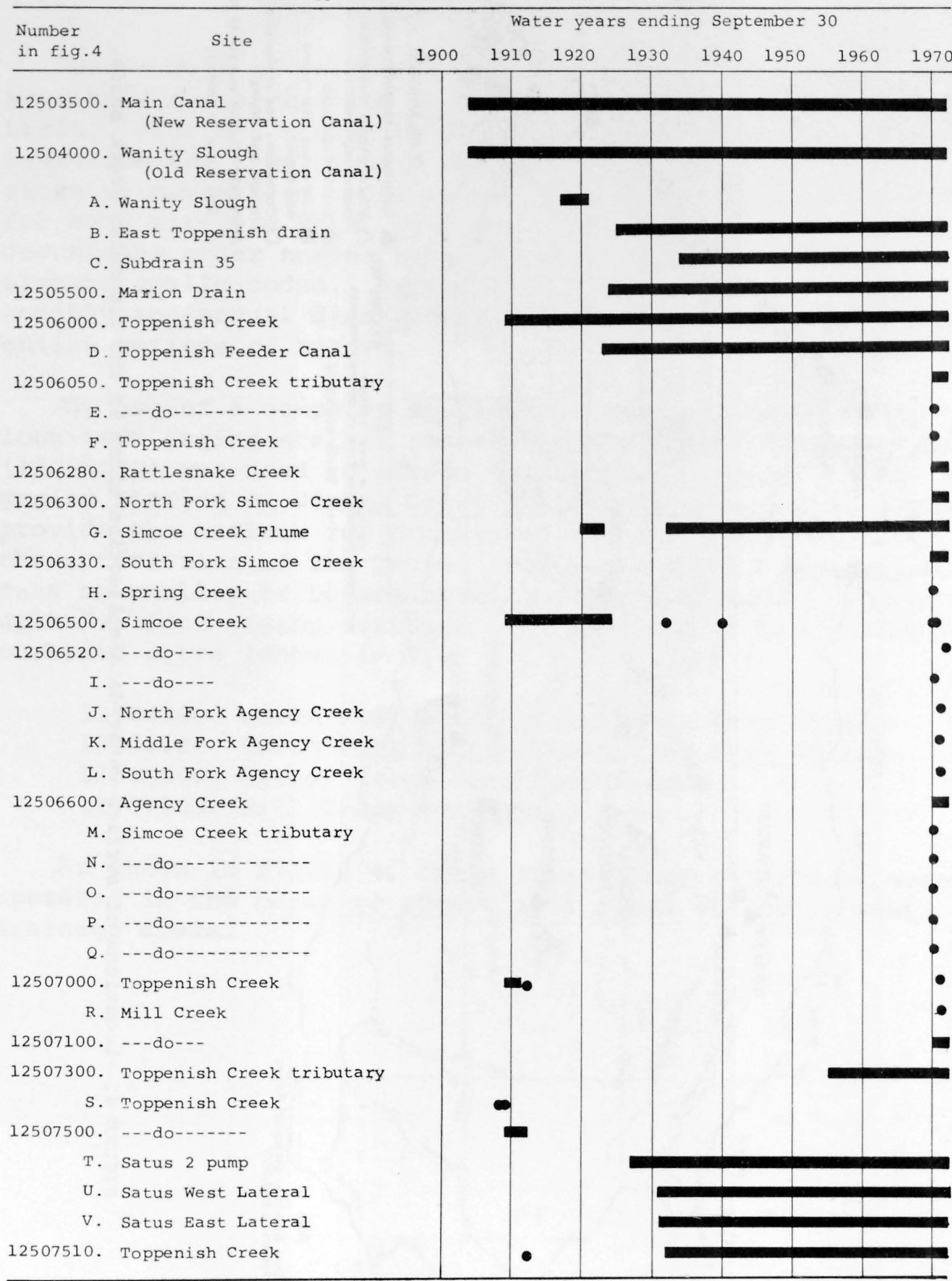

Explanation: Discharge record.

- Discharge measurements.

Note: Occasional flow measurements were made at some sites not listed--discharge measured was direct return flow to the Yakima River. 


\section{Streamflow Characteristics}

\section{Seasonal Variations}

The streams in the uplands of the basin may have highly variable flows throughout the year. This variability is generally dependent upon the physiography, geology, and the annual precipitation and temperature patterns that prevail in the upper parts of the basin.

Peak runoff in the streams usually coincides with the rapid melting of snow at low altitudes caused either by warm Chinook winds--usually in January or February or by inflow of warm, moist airmasses. The extensive flooding in January 1974 is a disastrous example of this latter type of snowmelt.

A less spectacular--but perhaps more typical--example of this peak-runoff phenomenon is shown by the data presented in figure 5. The lower graph is the 1971 daily streamflow hydrograph for the North Fork Simcoe Creek gage (12506300). The middle graph shows the daily maximum and minimum temperatures at a nearby representative weather station, and the upper bar graph shows the daily recorded precipitation.

In early January temperatures were low, no precipitation occurred, there was a substantial snowpack at low elevations in the basin, and streamflow was, consequently, quite low. Later in the month a warming trend began, precipitation began as snow and later became rain in the low altitudes, and two very high streamflow peaks resulted. A second and more prolonged period of high runoff occurred in April and May when temperatures rose and generally remained well above freezing, and the snowpack in the high parts of the basin melted and ran off.

After May, streamflow progressively decreases, and approaches a base-flow condition. Note the steady decline in streamflow from May through August in figure 5. This base flow in the upper part of the basin consists almost entirely of groundwater seepage into the stream and is only incidentally supplemented by runoff from rainfall. The lowest natural streamflows usually occur in late summer when ground-water levels are declining, evapotranspiration is high, and rainfall is sparse. 

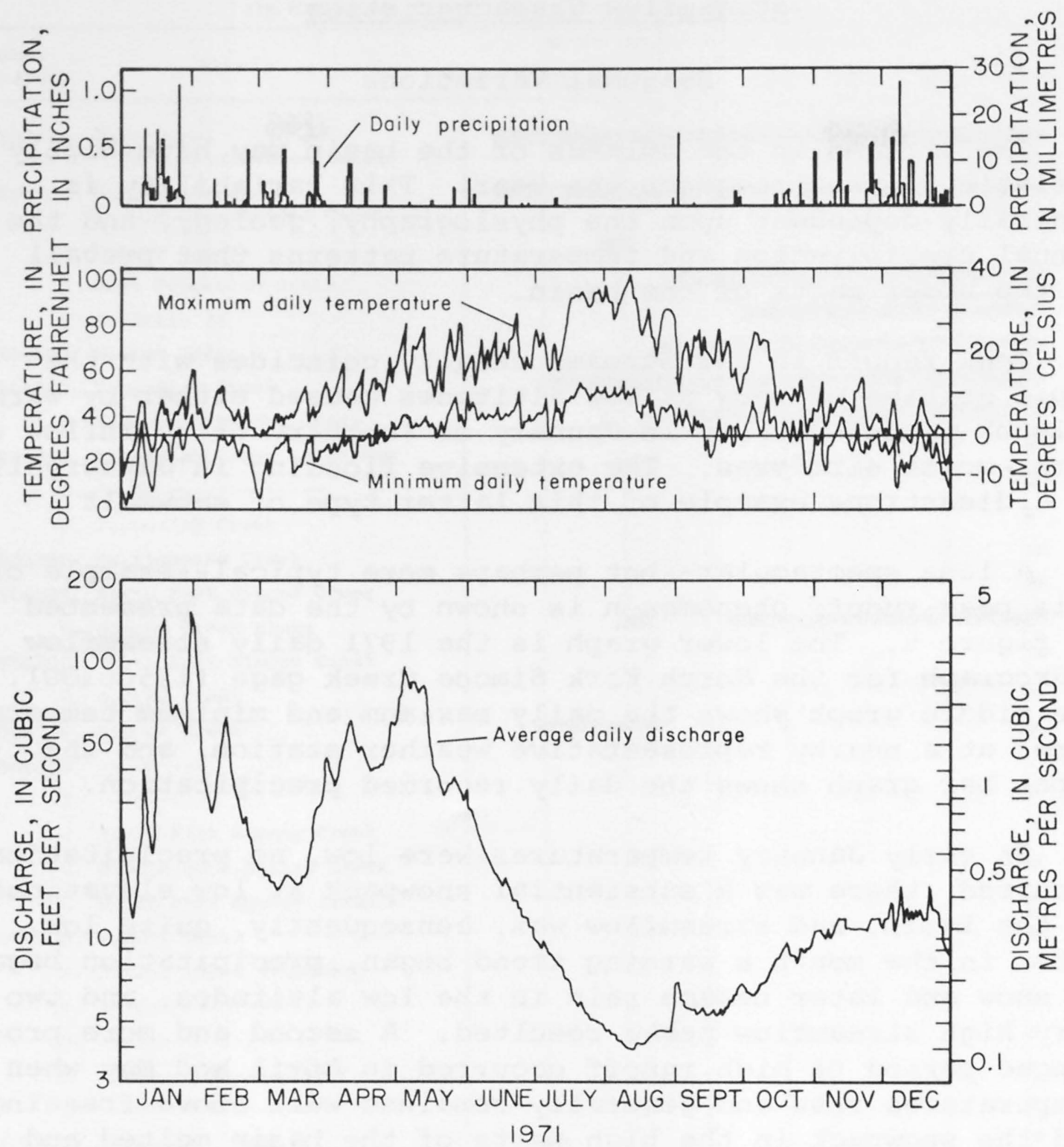

FIGURE 5.--Daily flows of North Fork Simcoe Creek near Fort Simcoe (12506300), and maximum and minimum daily temperatures and daily precipitation at Rimrock Tieton Dam. 
In the fall, as temperatures begin to drop, evapotranspiration also declines owing to plant maturity or killing frosts, and precipitation begins to increase. Thus, the long streamflow recession is checked, and the streams again begin to rise. This general trend toward increasing discharge from September into the fall is demonstrated by the hydrograph in figure 5 .

\section{Areal Variations}

Natural streams in adjacent basins generally have similar but not identical flow patterns throughout the year. This occurs because those factors which most affect streamflow characteristics--physiography, geology and climate--are similar.

Figure 6 illustrates this concept by comparing a 2 -year average monthly runoff per square mile of drainage area from Toppenish Creek (station 12506000, which includes diversions into Toppenish Feeder Canal) to that from the combined drainage areas for the two gaged sites on the North and South Forks of Simcoe Creek (stations 12506300 and 12506330). The bar graphs show that the runoff per square mile of drainage area from the Simcoe Creek basin consistently equals or exceeds that of the Toppenish basin, because the mean annual precipitation over the Toppenish Creek basin is only about 30 inches $(760 \mathrm{~mm})$ as compared to about 43 inches $(1,090 \mathrm{~mm})$ over the Simcoe Creek basin. However, the monthly streamflow pattern for both basins is similar. (Note that for both basins the highest monthly averages shown in figure 6 occur in May and the second highest are in March.) Although the average streamflow at the Toppenish Creek station during the 2-year period used for preparation of figure 6 exceeded the long-term average at that station, the relative distribution of runoff by months is demonstrated and is considered representative.

For comparison, figure 6 includes data for the 2-year average monthly precipitation at the White Swan ranger station (elevation $970 \mathrm{ft}$ or $296 \mathrm{~m}$ ) and at Tieton Dam (elevation $2,730 \mathrm{ft}$ or $832 \mathrm{~m}$ ) near Rimrock. The precipitation differences due to elevation are evident. The Tieton Dam data were used because no high-elevation precipitation data were available from the Toppenish Creek basin for that period, and, by virtue of similarities in altitude and terrain, the Tieton Dam values should be generally representative of the precipitation in the 


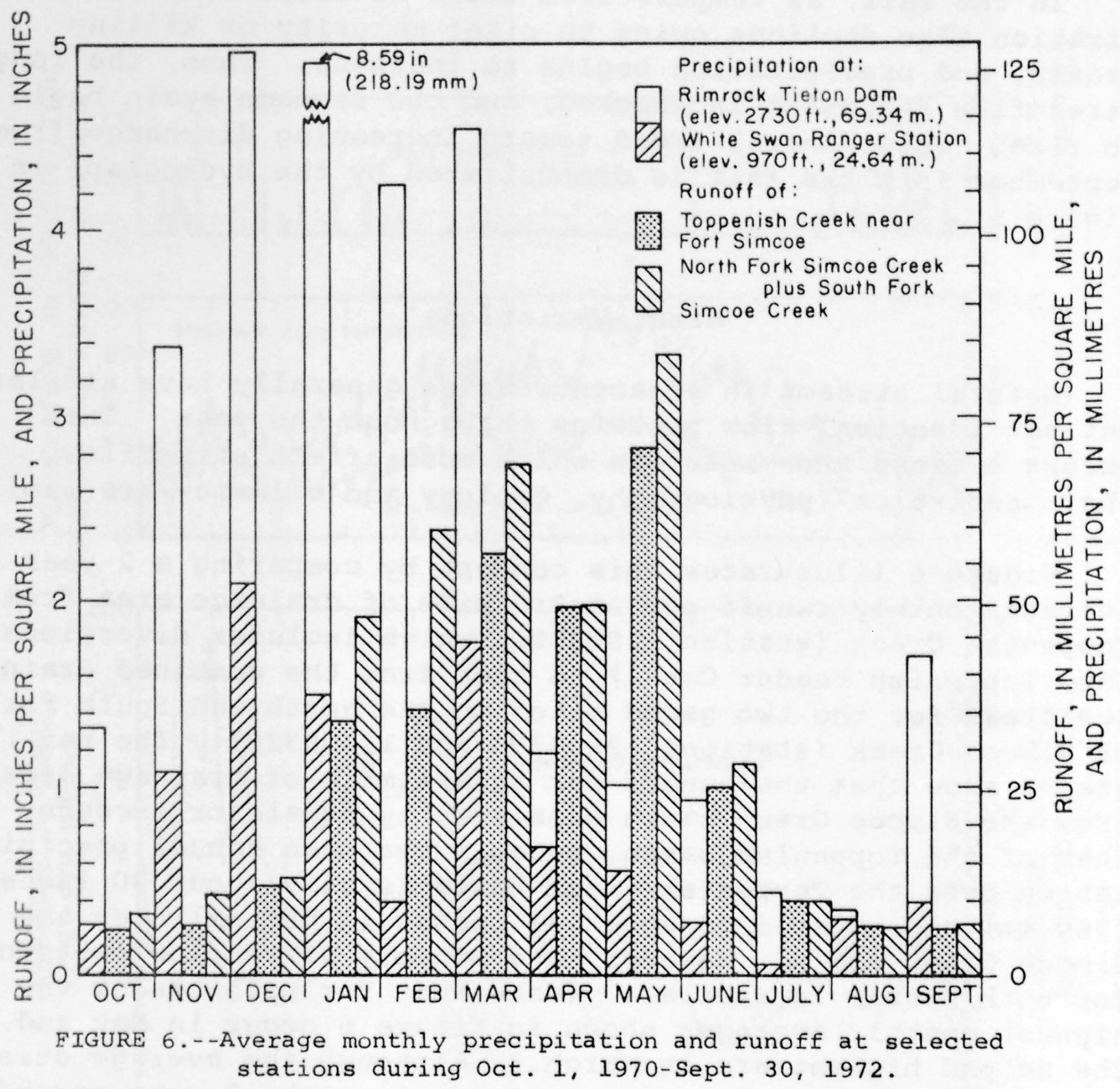


upper Toppenish and Simcoe Creek basins. Note that five consecutive months (November through March) had the highest precipitation, but the highest monthly streamflows did not occur until May--after the high-elevation snowpack melted.

The average precipitation at Tieton Dam for the 2-year period ending september 30, 1972, was about 125 percent of normal. If the normal 30 inches $(760 \mathrm{~mm})$ of precipitation in the upper Toppenish Creek basin above the gaging station is increased by 25 percent to about 38 inches ( $965 \mathrm{~mm}$ ), then the basin runoff for the 2 -year period was about 33.4 percent of total precipitation compared to about 29.6 percent expected during years of "normal" precipitation. In that 2-year period, about 104,000 acre-ft (128 million $\mathrm{m}^{3}$ ) of precipitation in excess of the average fell in the basin upstream from the gage site and about 49,000 acre-ft ( 60 million $\mathrm{m}^{3}$ ) of this excess water left the basin as surface-water runoff. Apparently because of the time of year when most of the precipitation occurred, much of the above-average precipitation could not be used by vegetation as evapotranspiration nor did it enter the ground-water reservoir.

\section{Flow Duration}

A streamflow-duration curve graphically portrays flow variability at a stream site for a specific period of past time. For that period, it shows the percentage of time that various flows were equaled or exceeded. The lower part of the flow-duration curve is a significant indicator of the quantity of water available in unregulated streams. Also, the slope of the lower part of the curve is a good index of basin storage, including ground-water storage--the flatter the slope, the more abundant the storage in the basin.

Flow-duration curves for the stations on Toppenish Creek near Fort Simcoe (12506000) and Simcoe Creek below Spring Creek, near Fort Simcoe (12506500), are shown in figure 7 . These curves show, for example, that at the Toppenish Creek station streamflow was equal to or greater than $16 \mathrm{ft}^{3} / \mathrm{s}$ $\left(0.45 \mathrm{~m}^{3} / \mathrm{s}\right) 90$ percent of the time during the period 1944-72. Conversely, the flow was less than $16 \mathrm{ft}^{3} / \mathrm{s}\left(0.45 \mathrm{~m}^{3} / \mathrm{s}\right) 10$ percent of the time during the same period. 


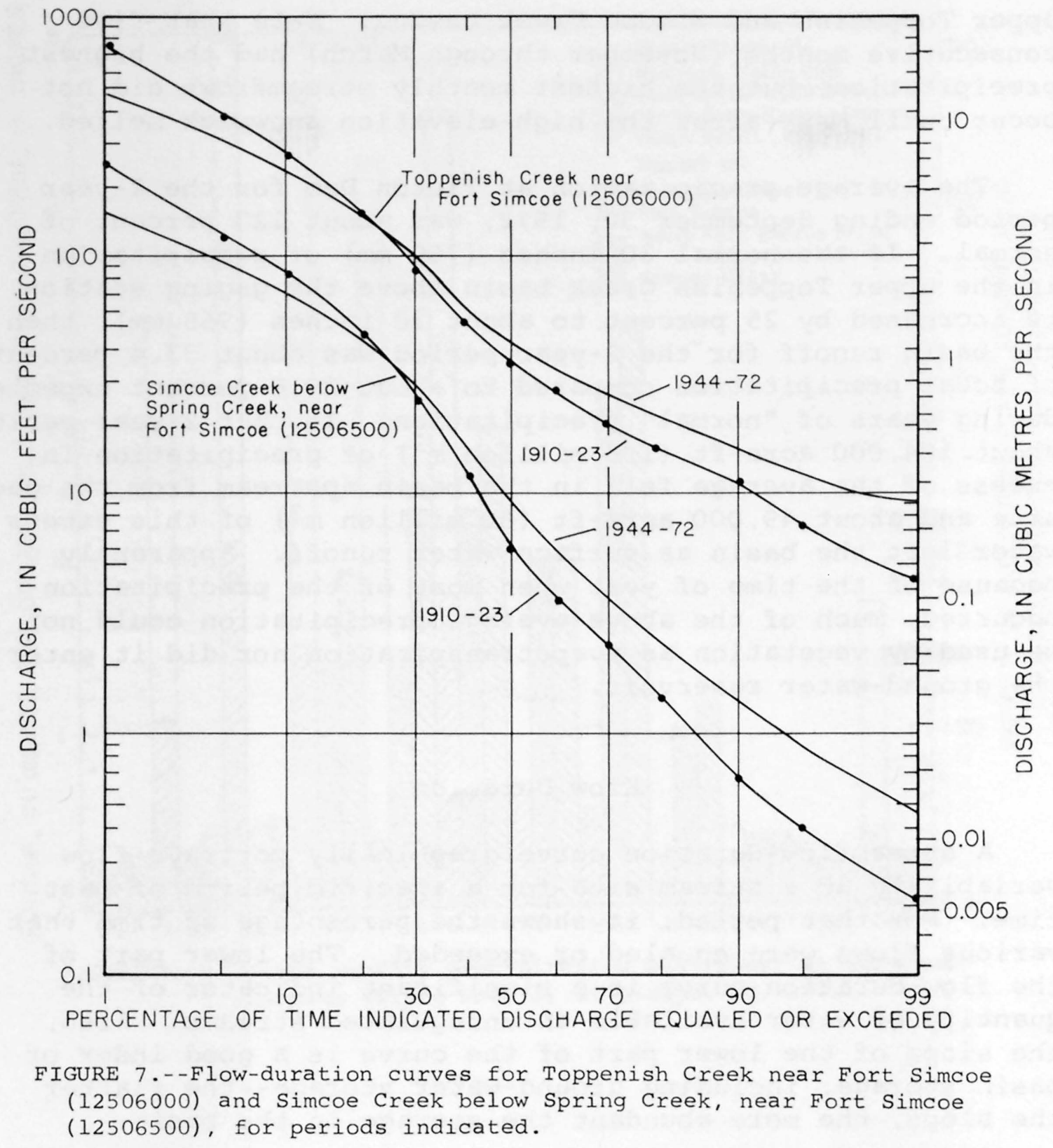


The figure contains two curves for each stream--one labeled 1910-23, and the other 1944-72. As mentioned on page 14, the long-term record for the Toppenish Creek gaging station was used to synthetically extend the Simcoe Creek record period to 1944-72. Also, the streamflow data for Simcoe Creek included water diverted through the Simcoe Creek flume.

The flow-duration curve for 1944-72 for the Simcoe Creek station indicates that about 90 percent of the time the flow was equal to or greater than $1.3 \mathrm{ft}^{3} / \mathrm{s}\left(0.037 \mathrm{~m}^{3} / \mathrm{s}\right)$ or, conversely, was less than $1.3 \mathrm{ft} 3 / \mathrm{s}\left(0.037 \mathrm{~m}^{3} / \mathrm{s}\right)$ about 10 percent of the time. The relatively steep slopes of the lower parts of the flow-duration curves for both streams indicate that there is relatively little ground-water contribution to flow in this part of the basin.

\section{Frequency of Low Flows}

The flow-duration curve, useful as it is for water-availability studies, does not indicate the sequence or frequency of flows. This deficiency is overcome by flow-frequency curves that show the average frequency, in years, at which specific average discharges may be expected to occur. Thus, the lowflow-frequency curve for a particular stream site shows how often the average discharge for specific time increments may be expected to be less than a selected discharge.

Families of low-flow-frequency curves for Toppenish Creek near Fort Simcoe (fig. 8) and Simcoe Creek below Spring Creek, near Fort Simcoe (fig。9), were developed for five selected time increments ranging from 7 to 183 days. In figure 8 for Toppenish Creek, the 2-year recurrence interval intersects the 7 -day low-flow curve at $14.5 \mathrm{ft}^{3} / \mathrm{s}\left(0.411 \mathrm{~m}^{3} / \mathrm{s}\right)$. This means that the average natural stream discharge may be expected to be less than $14.5 \mathrm{ft}^{3} / \mathrm{s}\left(0.411 \mathrm{~m}^{3} / \mathrm{s}\right)$ during any 7 -day period at intervals averaging 2 years. The probability of such an event occurring in any future year is 0.5 (one chance in two) which is the reciprocal of the recurrence interval. 


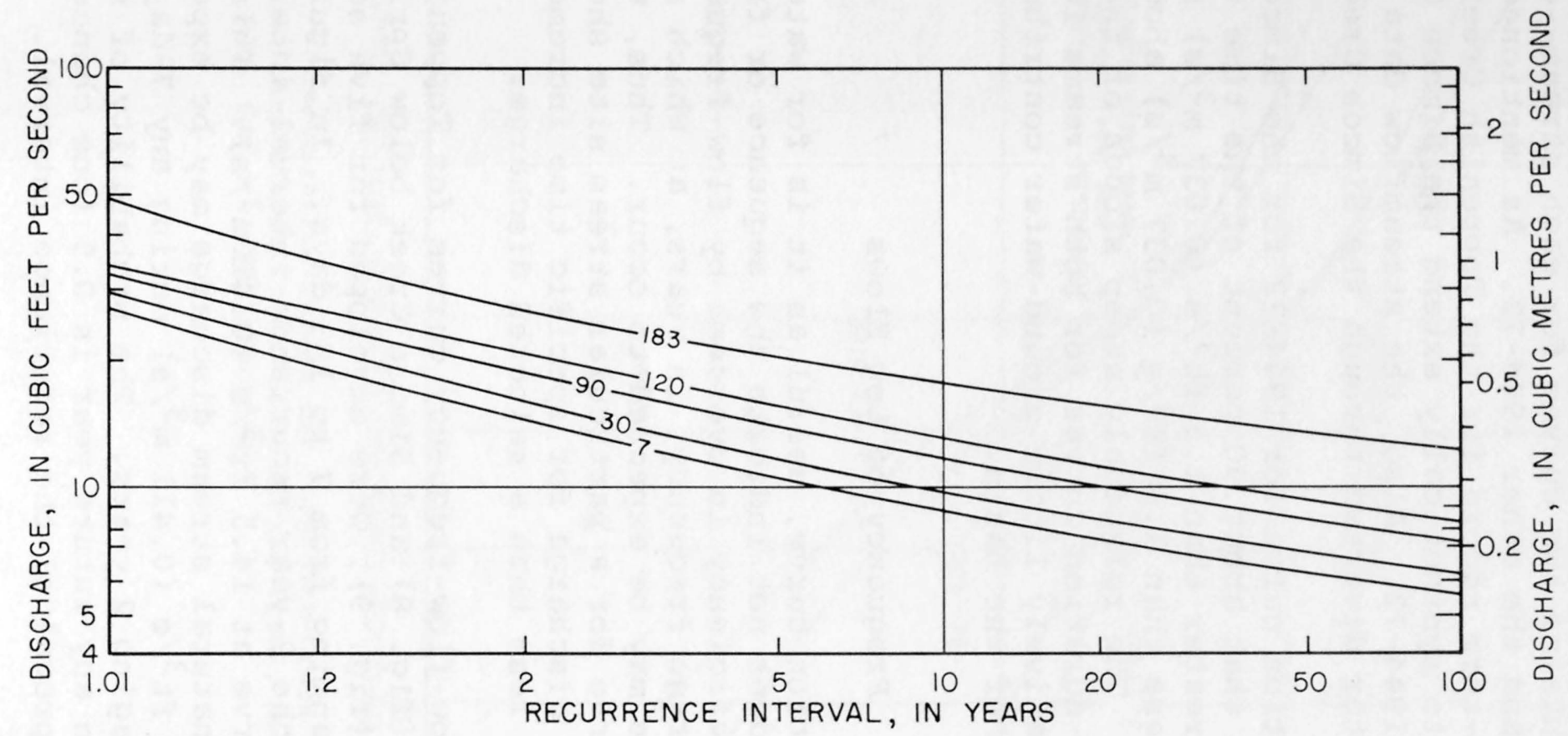

FIGURE 8.--Low-flow-frequency curves of annual lowest mean discharges for indicated numbers of consecutive days, Toppenish Creek near Fort Simcoe (12506000). 


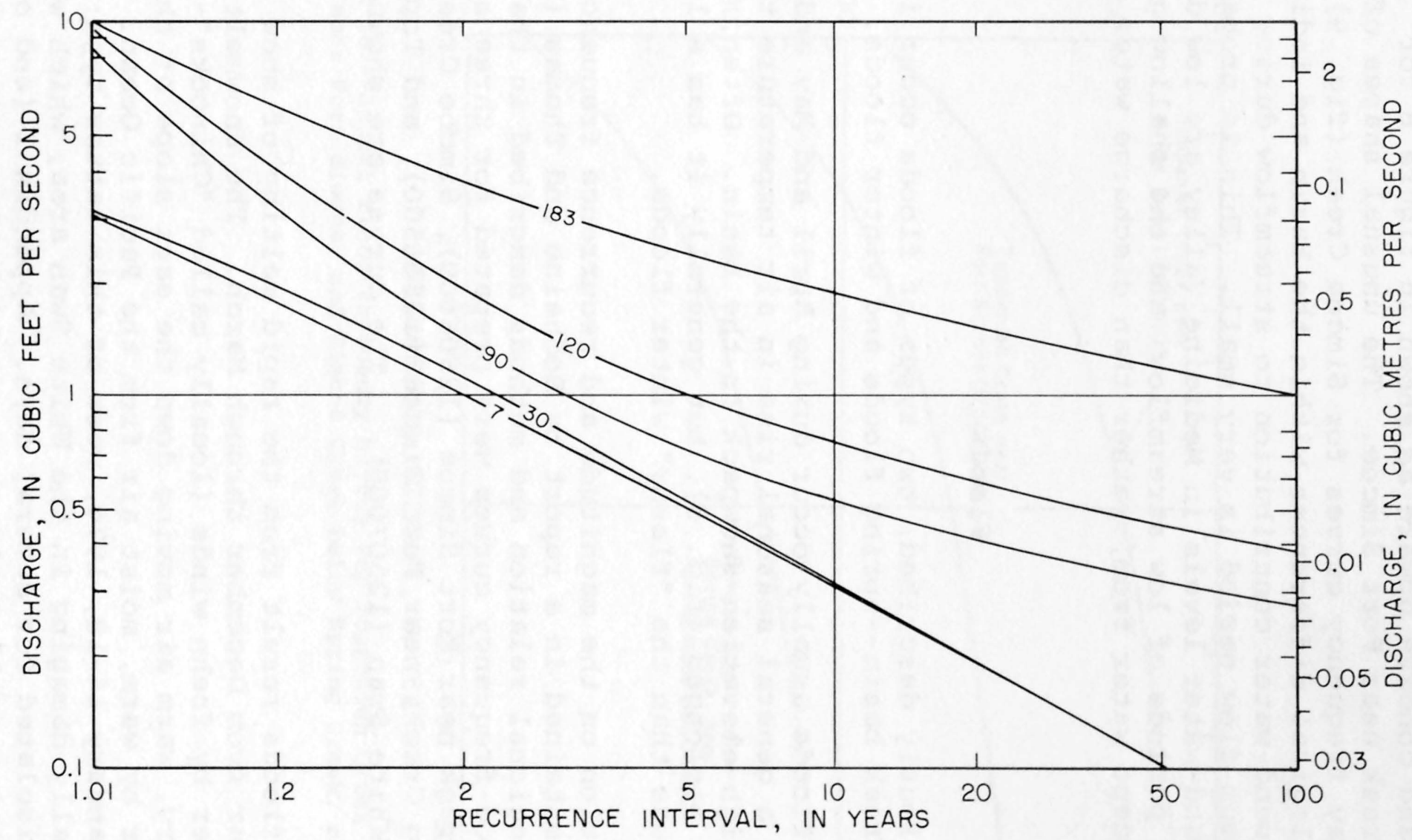

FIGURE 9.--Low-flow-frequency curves of annual lowest mean discharges for indicated numbers of consecutive days, Simcoe Creek below Spring Creek, near Fort Simcoe $(12506500)$. 
Usually, low-flow-frequency curves for perennial streams are smooth and concave upward as shown in figure 8 for Toppenish Creek near Fort Simcoe. The unusual shapes of the 7- and 30-day frequency curves for Simcoe Creek (fig. 9) reflect geological differences within the basin and indicate that the ground-water contribution to streamflow during the annual minimum-flow period is very small. This is probably because ground-water levels in Medicine valley are low during late-summer periods of low streamflow, and the shallow gravels probably accept water from, rather than discharge water to, the stream.

\section{Floods}

As previously described, two types of floods occur in the Toppenish Creek basin--spring floods and winter floods.

Spring floods usually occur during April and May and are a result of a general seasonal rise in air temperature that melts the high-elevation snowpack in the basin. Often, this flooding is prolonged (fig. 5), but generally it has a lower peak magnitude than the "flashy" winter floods.

Information on the magnitude and recurrence frequency of floods is contained in a report by Bodhaine and Thomas (1964). Using the regional relation and methods described in that report, flood-frequency curves were prepared for three sites: Toppenish Creek near Fort Simcoe (12506000), Simcoe Creek below Spring Creek, near Fort Simcoe (12506500), and Toppenish Creek near White Swan (12507000). The curves are shown in figure 10.

Winter floods result from the rapid melting of snow and usually occur from December through March. The snowmelt is caused either by foehn winds (locally called "Chinooks"-formed of dry, warm air moving down the east slope of the Cascades) or by warm, moist air from the Pacific Ocean. The floods of January 14-18, 1974, were of this latter type; they were especially damaging in the White Swan area, which was completely isolated for several days. Appendix I (end of report) contains small-scale maps on which the maximum extent of the 1974 flooding in the basin has been approximately delineated. Because the flooding was so extensive, the exact area of inundation and the maximum discharge are unknown. However, based on the maximum discharge of about $33,900 \mathrm{ft}^{3} / \mathrm{s}$ $\left(960 \mathrm{~m}^{3} / \mathrm{s}\right)$ determined for Satus Creek near Toppenish (12508500), the Toppenish Creek flood peak may have exceeded 28,300 ft $3 / \mathrm{s}$ $\left(793 \mathrm{~m}^{3} / \mathrm{s}\right)$. 


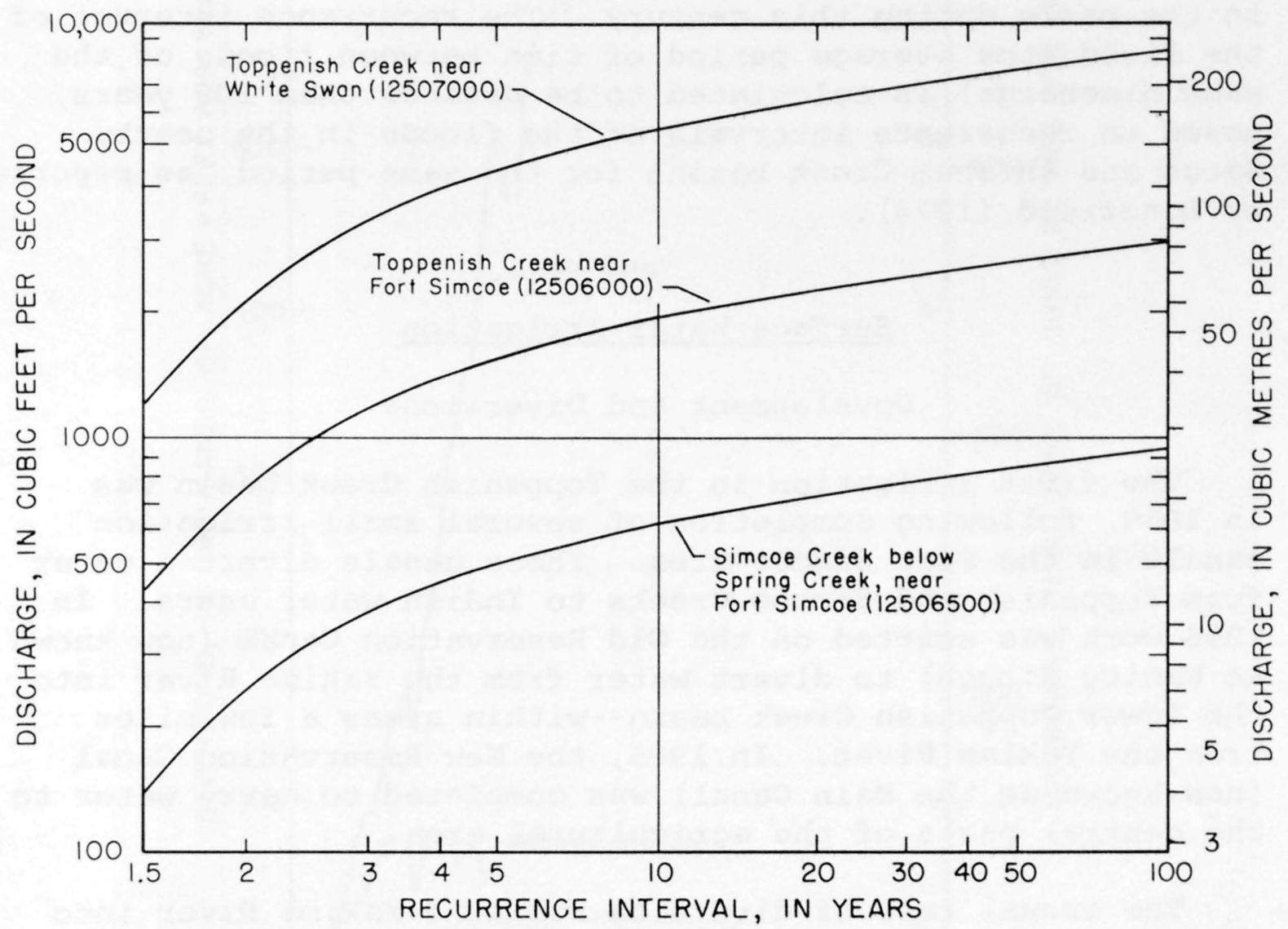

FIGURE 10.--Annual flood-frequency curves for Toppenish Creek near white Swan and near Fort Simcoe, and Simcoe Creek below Spring Creek, near Fort Simcoe. 
Note on figure 10 that a flood on Toppenish Creek at White Swan with an average recurrence interval of 100 years would have a peak discharge of about $8,400 \mathrm{ft}^{3} / \mathrm{s}\left(238 \mathrm{~m}^{3} / \mathrm{s}\right)--a$ discharge much less than that of January 1974. Undoubtedly, the magnitude of that flood was much greater than any other flood in the basin during this century. The recurrence interval of the flood (the average period of time between floods of the same discharge) is calculated to be greater than 100 years, based on recurrence intervals of the floods in the nearby Satus and Ahtanum Creek basins for the same period, as reported by Longfield (1974).

\section{Surface-Water Irrigation}

\section{Development and Diversions}

The first irrigation in the Toppenish Creek basin was in 1859, following completion of several small irrigation canals in the Fort Simcoe area. These canals diverted water from Toppenish and Simcoe Creeks to Indian water users. In 1896 work was started on the old Reservation Canal (now known as Wanity Slough) to divert water from the Yakima River into the lower Toppenish Creek basin--within areas a few miles from the Yakima River. In 1905, the New Reservation Canal (now known as the Main Canal) was completed to carry water to the central parts of the agricultural area.

The annual rate of diversion from the Yakima River into the Toppenish basin increased rapidly in the early 1900's. As shown in figure 11. diversion into the Main Canal increased from about 25,000 acre-ft $\left(30.8\right.$ million $\left.\mathrm{m}^{3}\right)$ in 1905 to about 647.000 acre-ft (798 million $\mathrm{m}^{3}$ ) in 1935. Thereafter until 1972, the diversion averaged about 633,000 acre-ft (780 million $\left.\mathrm{m}^{3}\right)$, but fluctuated between extremes of 687,200 acre-ft (847 milition $\mathrm{m}^{3}$ ) in 1947 and 588,100 acre-ft (725 million $\mathrm{m}^{3}$ ) in 1963.

The average annual diversion through wanity slough prior to 1924 was 67,100 acre-ft $\left(82.7\right.$ million $\left.\mathrm{m}^{3}\right)$. However, the yearly average was only 17.900 acre-ft (22.1 million $\mathrm{m}^{3}$ ) from 1925-72 and only 9,860 acre-ft (12.2 million $\mathrm{m}^{3}$ ) from 1960-72. In recent years, Wanity slough has been used mainly during the post-irrigation season as a carrier of water from irrigation drains. During the irrigation season, this water is used to irrigate land, both north and south of the city of Toppenish, and the excess is allowed to flow into Marion Drain. 


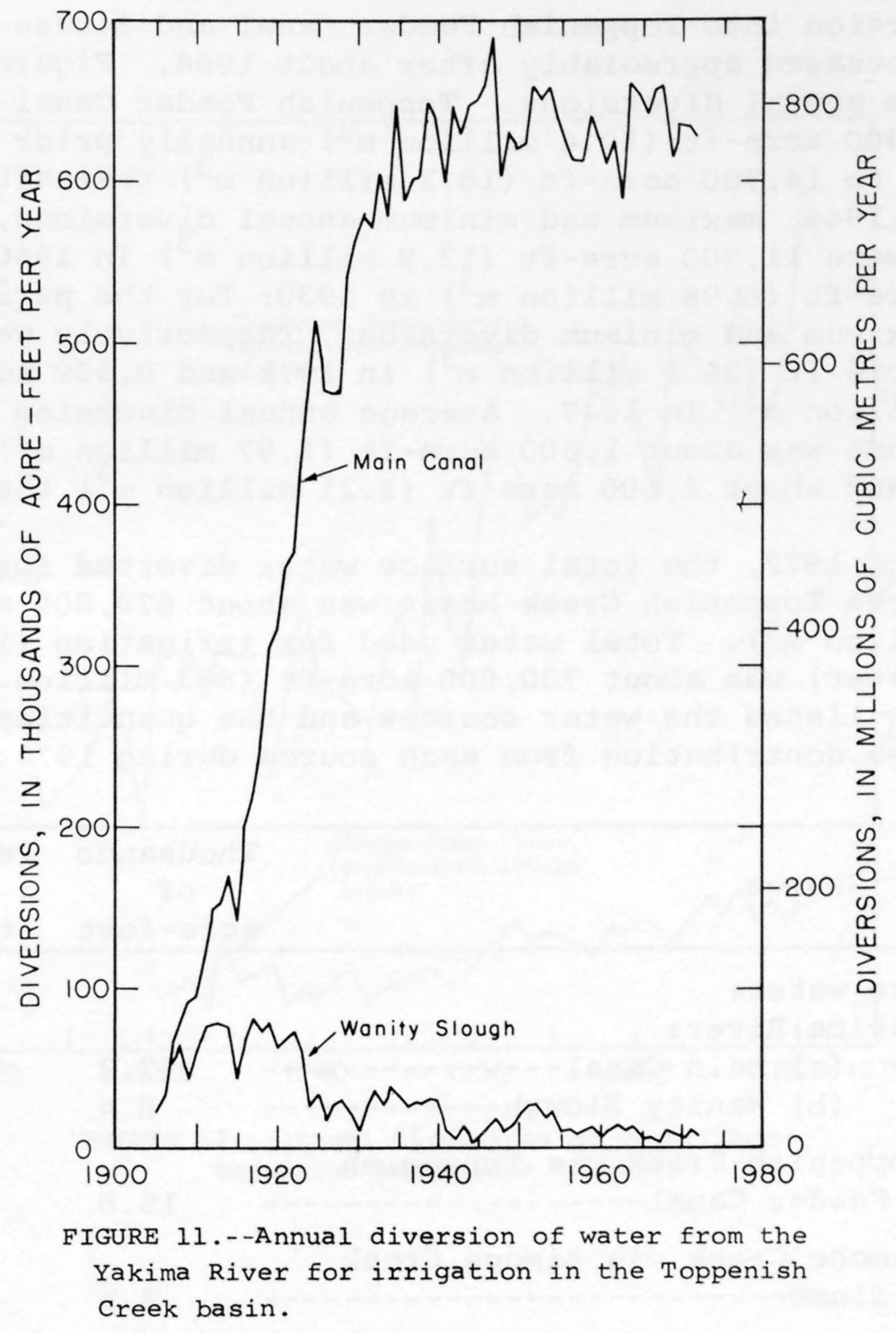


Diversion into Toppenish Feeder Canal and Simcoe Creek flume increased appreciably after about 1944. Figure 12 shows the annual diversions. Toppenish Feeder Canal averaged about 8,400 acre-ft ( 10.4 million $\mathrm{m}^{3}$ ) annually prior to 1944 compared to 14,780 acre-ft $\left(18.2\right.$ million $\mathrm{m}^{3}$ ) thereafter. Prior to 1944, maximum and minimum annual diversions, respectively, were 11,300 acre-ft $\left(13.9\right.$ million $\mathrm{m}^{3}$ ) in 1940 and 5,660 acre-ft $\left(6.98\right.$ million $\left.\mathrm{m}^{3}\right)$ in 1930; for the period after 1944, maximum and minimum diversions, respectively were 21,210 acre-ft $\left(26.2\right.$ million $\left.\mathrm{m}^{3}\right)$ in 1971 and 8,309 acre-ft $\left(10.2\right.$ million $\mathrm{m}^{3}$ ) in 1947. Average annual diversion in Simcoe Creek flume was about 1,600 acre-ft ( $1.97 \mathrm{million} \mathrm{m}^{3}$ ) prior to 1944 and about 2,600 acre-ft $\left(3.21\right.$ million $\left.\mathrm{m}^{3}\right)$ thereafter.

During 1972, the total surface water diverted for irrigation in the Toppenish Creek basin was about 679,000 acre-ft $\left(837\right.$ million $\mathrm{m}^{3}$ ). Total water used for irrigation (including ground water) was about 700,000 acre-ft $\left(863\right.$ million $\left.\mathrm{m}^{3}\right)$. Below are listed the water sources and the quantities and percentage contribution from each source during 1972:

\begin{tabular}{|c|c|c|}
\hline Source & $\begin{array}{l}\text { Thousands } \\
\text { of } \\
\text { acre-feet }\end{array}$ & $\begin{array}{l}\text { Percent } \\
\text { of } \\
\text { total }\end{array}$ \\
\hline $\begin{array}{l}\text { Surface water: } \\
\text { Yakima River: } \\
\text { (a) Main Canal } \\
\text { (b) Wanity Slough }\end{array}$ & $\begin{array}{r}647.2 \\
8.4\end{array}$ & $\begin{array}{r}92.5 \\
1.2\end{array}$ \\
\hline $\begin{array}{l}\text { Toppenish Creek via Toppenish } \\
\text { Feeder Canal- } \\
\text { Simcoe Creek via Simcoe Creek } \\
\text { flume-1. }\end{array}$ & 19.8 & 2.8 \\
\hline $\begin{array}{l}\text { Ground water: } \\
\text { (a) from wells in the basalt-.. } \\
\text { (b) from wells in the valley } \\
\text { fill- }\end{array}$ & $\begin{array}{r}17.5 \\
3.5\end{array}$ & $\begin{array}{r}2.5 \\
.5\end{array}$ \\
\hline Total (rounded)-- & 700.0 & 100.0 \\
\hline
\end{tabular}




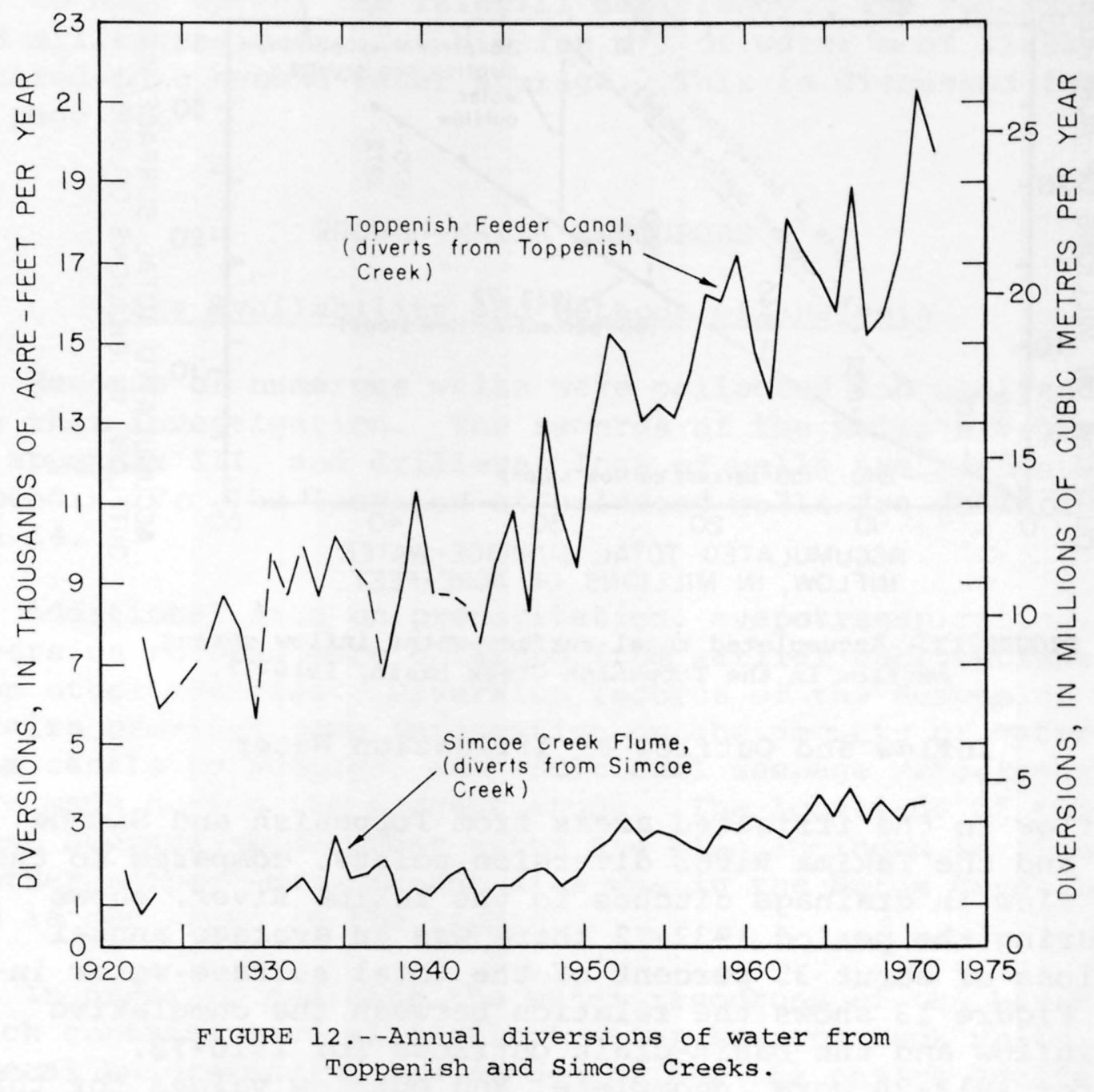




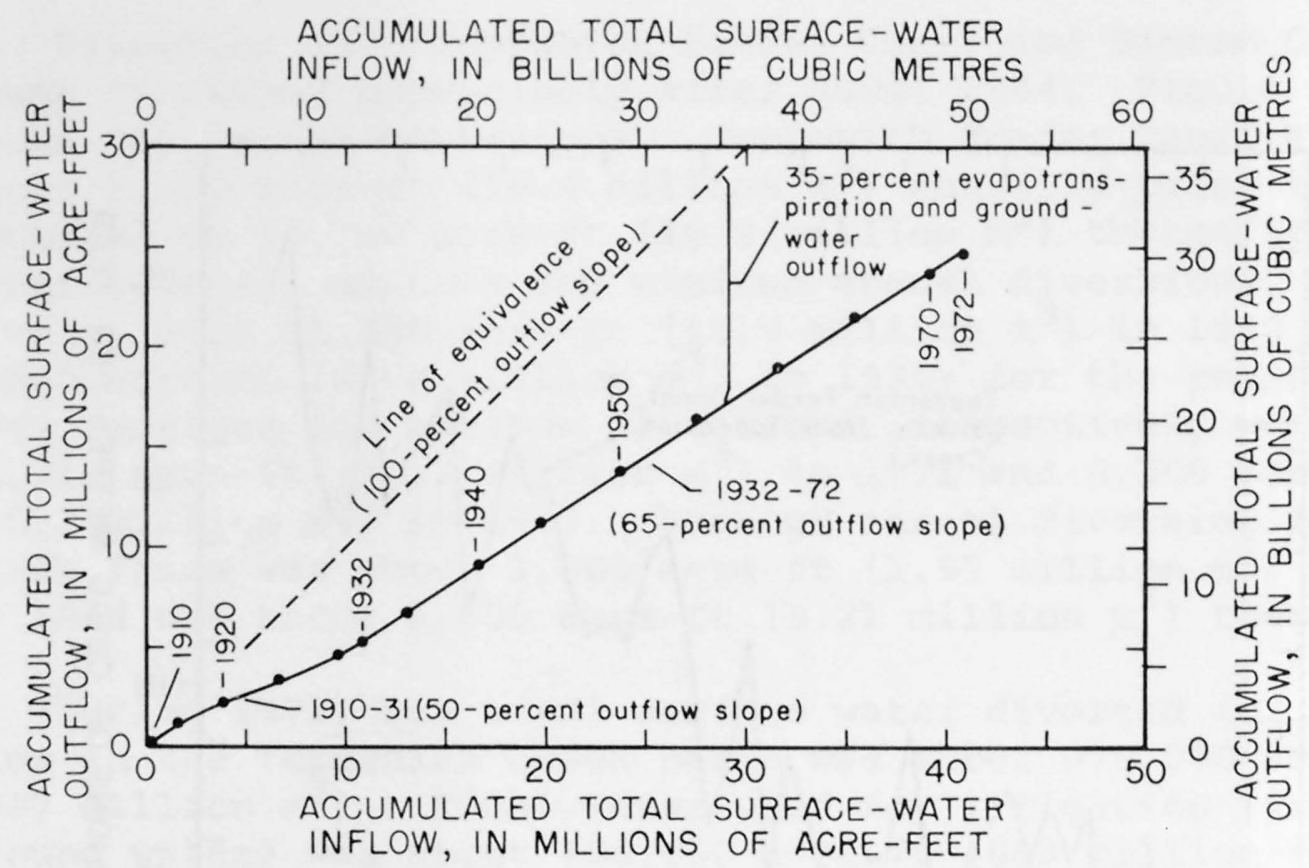

FIGURE 13.--Accumulated total surface-water inflow versus outflow in the Toppenish Creek basin, 1910-72.

\section{Inflow and Outflow of Irrigation Water}

Inflow to the irrigated areas from Toppenish and Simcoe Creeks and the Yakima River diversion points, compared to the return flow in drainage ditches to the Yakima River, shows that during the period 1932-72 there was an average annual water loss of about 35 percent of the total surface-water inflow. Figure 13 shows the relation between the cumulative basin inflow and the basin-drain outflows for 1910-72.

(Data for 1913-24 were incomplete, and outflow values for this period were estimated.) Figure 13 shows that for 1910-31 the average annual loss was considerably greater--about 50 percent. The difference in annual water-loss rates for the two periods may be partly attributed to ground-water recharge in the early years when excess water went into ground-water storage, raising ground-water levels to new, shallower positions.

From 1910 to 1931 about 10.3 million acre-ft (12.7 billion $\mathrm{m}^{3}$ ) of water flowed into the basin, and about 5.2 million acre-ft $\left(6.4\right.$ billion $\mathrm{m}^{3}$ ) returned to the Yakima River. Of the $5.1 \mathrm{mil}-$ lion acre-ft $\left(6.3\right.$ billion $\left.\mathrm{m}^{3}\right)$ remainder, about 3.8 million acre-ft ( 4.7 billion $\mathrm{m}^{3}$ ) is estimated to have been lost to evapotranspiration and ground-water seepage to the Yakima River. Rainfall for 
1920-31 was nearly 1 ft $(0.3 \mathrm{~m})$ deficient, and the estimated evapotranspiration includes 0.2 million acre-ft $(0.2$ billion $\mathrm{m}^{3}$ ) to make up for the rainfall deficiency. The remaining 1.3 million acre-ft ( 1.6 billion $\mathrm{m}^{3}$ ) of water most likely entered into ground-water storage. This is discussed further on page 40 .

\section{GROUND-WATER RESOURCES}

\section{Data Availability and Methods of Analysis}

Records of numerous wells were collected and analyzed during this investigation. The records of the wells are given in appendix III, and drillers' logs of wells are presented in appendix IV. The location of selected wells are shown in figure 14 .

Additional data on precipitation, evapotranspiration, and diversion records were obtained from earlier publications and from other agencies. Diversion records of the Bureau of Indian Affairs provided some information on the amounts of water lost from canals by seepage, and additional seepage measurements were made during the present study. The locations of two of these seepage-measurement sites are also included in figure 14. Another seepage-measurement site was in the Satus Creek basin and is not shown in the figure.

In order to evaluate the water resources of the basin, which contains several distinct water-bearing rock units, a general understanding was needed of how the entire aquifer system functions and the quantities of water moving through the system. As an aid to understanding the flow system, a detailed water budget was developed. The development of this water budget involved using measured and calculated or estimated values of water movement to construct a flow-system model that was internally consistent and reasonable in terms of established hydrologic principles and hydraulic characteristics of the types of rocks present.

In the following pages the individual water-bearing rock units are described in terms of their areal distribution (shown in fig. 15), their hydraulic characteristics, water levels, the movement of water they contain, and their present. state of development. For a summary of these characteristics see table 2 . 


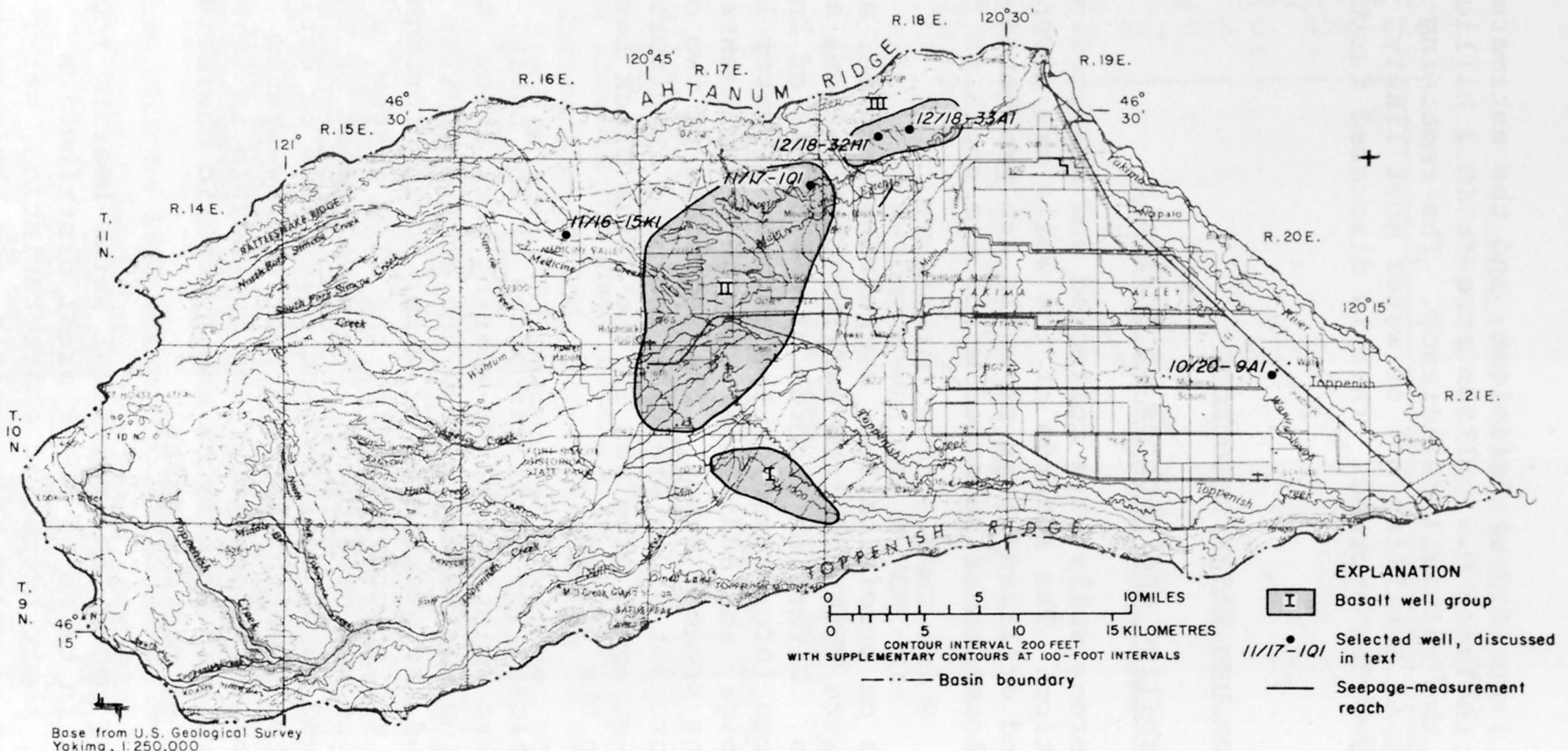

FIGURE 14.--Toppenish Creek basin showing locations of selected wells, seepage-data sites, and areas of various groups of wells tapping the basalt aquifer. 


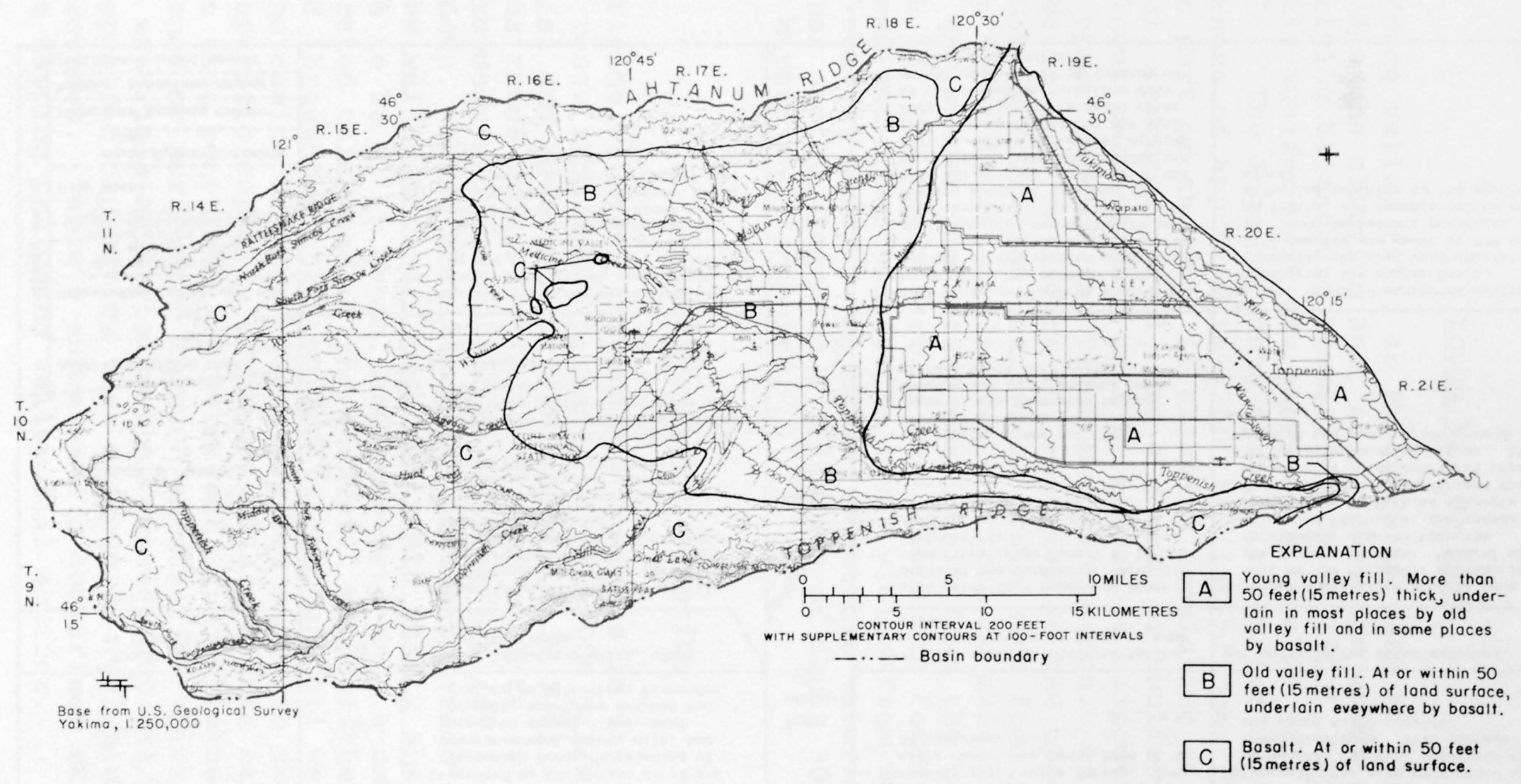

FIGURE 15.--Areal distribution of hydrogeologic units in the Toppenish Creek basin. 
TABLE 2.--Stratigraphic relationships and hydrologic characteristics of the geologic units in the Toppenish Creek basin

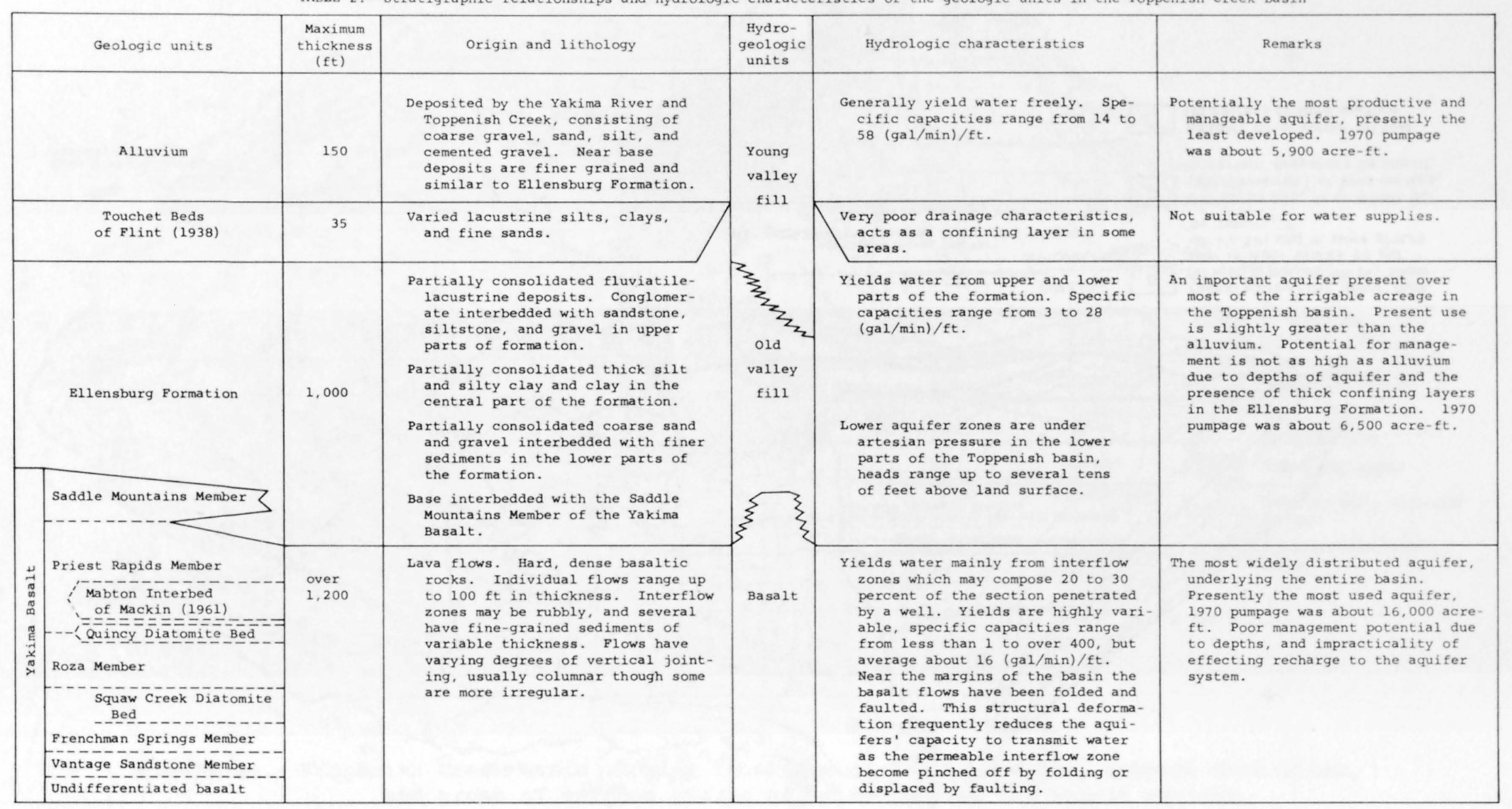




\section{Young Valley Fill}

Young valley fill, as the term is used in this report, includes the alluvium and, at places, the upper part of the underlying Ellensburg Formation (Smith 1903). Typical sections of this aquifer unit are shown by schematic well logs in figure 16. The logs indicate that this aquifer unit reaches a thickness of approximately $500 \mathrm{ft}(150 \mathrm{~m})$ near Wapato. The upper part of the unit is alluvium consisting of silt, sand, gravel, cemented gravel, and a coarse or bouldery basal gravel. The lower part of this unit at places is composed of the permeable upper part of the Ellensburg Formation. As shown by the schematic logs in figure 16, material in the upper part of the Ellensburg Formation differs in grain size from place to place; about the only generalization that can be made is that in areas near the border separating the basalt from the old valley fill (fig. 15) the upper part of the Ellensburg Formation is fine grained and not conducive to large yields from wells. In the east-central part of the basin, permeable materials extend to greater depths, reaching a thickness of about $300 \mathrm{ft}(90 \mathrm{~m})$ near Wapato and Toppenish.

\section{Aquifer Characteristics}

Yields of wells tapping the aquifers in the young valley fill range from about 5 to more than $1,000 \mathrm{gal} / \mathrm{min}(0.3$ to $63 \mathrm{l} / \mathrm{s})$ and average about $30 \mathrm{gal} / \mathrm{min}(1.9 \mathrm{l} / \mathrm{s})$. Specific capacities range from about 2 to 58 (gal $/ \mathrm{min}) / \mathrm{ft}[0.4$ to $12(1 / \mathrm{s}) / \mathrm{m}]$ of drawdown and average about $10(\mathrm{gal} / \mathrm{min}) / \mathrm{ft}[2(1 / \mathrm{s}) / \mathrm{m}]$ of drawdown. These statistics are somewhat biased due to the nature of the wells sampled. Most wells are fairly shallow, 20 to 60 ft $(6$ to $18 \mathrm{~m})$ in depth, and penetrate only a small part of the saturated thickness of the aquifer. Many of these wells are cased throughout their entire length, and all water has to enter at the casing bottom. These factors serve to reduce the yield and specific capacity of these wells. On the other hand, several wells that penetrate a greater saturated thickness and are screened or perforated through substantial thicknesses of permeable materials have yields that average $700 \mathrm{gal} / \mathrm{min}(44 \mathrm{l} / \mathrm{s})$ and specific capacities that average $39(\mathrm{gal} / \mathrm{min}) / \mathrm{ft}[8(1 / \mathrm{s}) / \mathrm{m}]$ of drawdown. Table 3 summarizes a comparison of the types of wells tapping the young valley fill aquifer. 


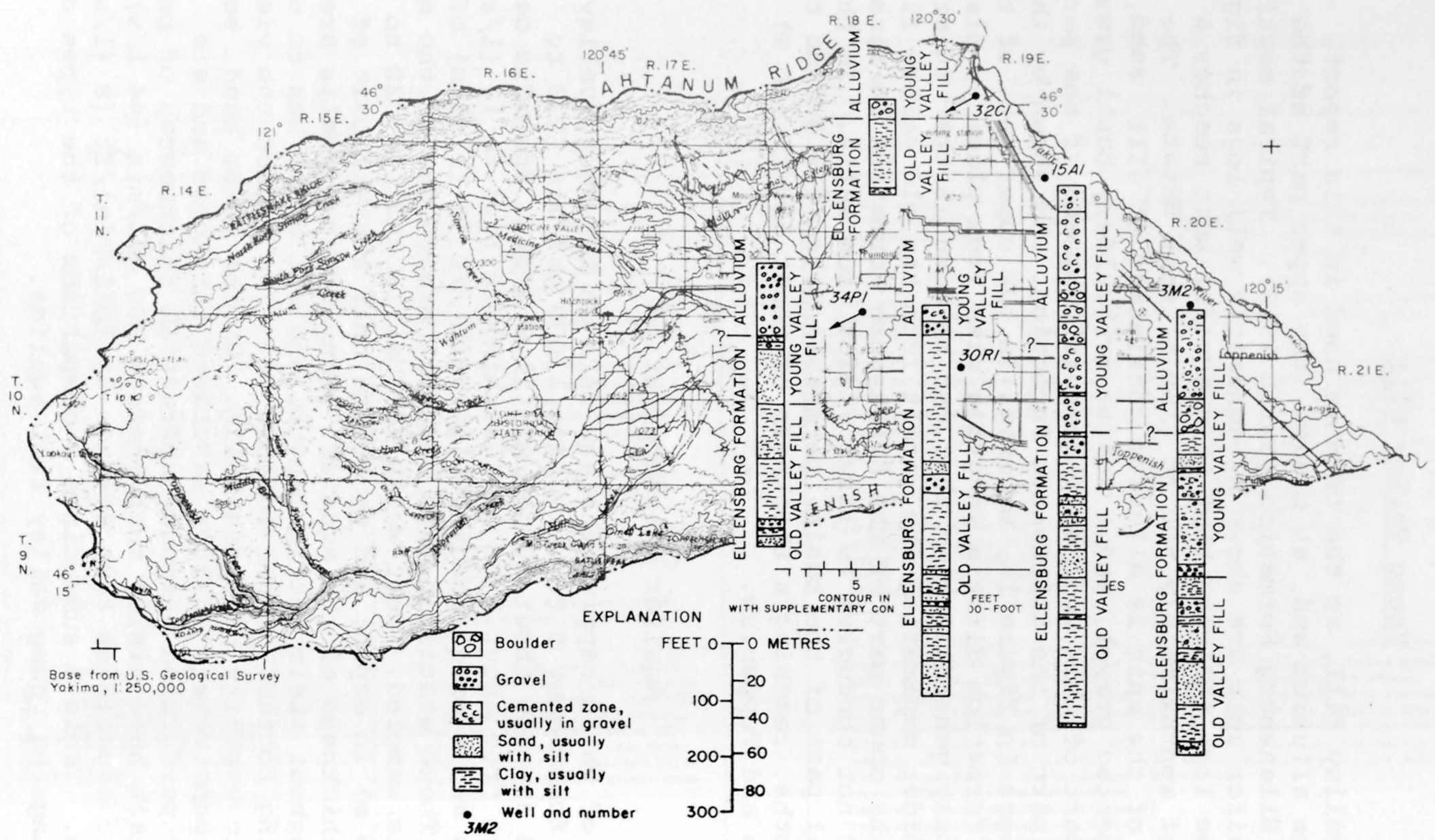

FIGURE 16.--Schematic logs of wells penetrating the young valley fill and partially penetrating the old valley fill. 
TABLE 3.--A comparison of types of wells constructed in the young valley fill

\begin{tabular}{|c|c|c|c|c|}
\hline well type & Common use & Method of construction & $\begin{array}{l}\text { Typical } \\
\text { specific } \\
\text { capacities } \\
{[(\text { gal/min)/ft }} \\
\text { of drawdown] }\end{array}$ & Remarks \\
\hline $\begin{array}{l}\text { Concrete ring } \\
\text { well (dug) }\end{array}$ & $\begin{array}{l}\text { Sumps, irriga- } \\
\text { tion, and fire } \\
\text { protection }\end{array}$ & $\begin{array}{l}\text { Concrete rings } 36 \text { to } 60 \text { inches } \\
\text { in diameter form the well } \\
\text { casing, usually the wells are } \\
\text { dug by a "clam shell" to an } \\
\text { average depth of } 22 \text { feet. }\end{array}$ & 58 & $\begin{array}{l}\text { Low cost of construction. Depth is } \\
\text { limited, usually wells do not pene- } \\
\text { trate any cemented materials. Since } \\
\text { cemented zones commonly occur at } 20- \\
\text { to } 30 \text {-foot depths in this aquifer } \\
\text { this restricts the areas in which } \\
\text { this type of well construction is } \\
\text { feasible to those in which the water } \\
\text { table is fairly close to land surface } \\
\text { during the periods the well is in use. } \\
\text { High potential for contamination from } \\
\text { surface water. }\end{array}$ \\
\hline $\begin{array}{l}\text { Screened or per- } \\
\text { forated-casing } \\
\text { wells (drilled) }\end{array}$ & $\begin{array}{l}\text { Municipal and } \\
\text { industrial } \\
\text { supplies }\end{array}$ & $\begin{array}{l}\text { A steel casing } 6 \text { to } 24 \text { inches } \\
\text { in diameter lines the well } \\
\text { bore. Adjacent to permeable } \\
\text { water-bearing materials, the } \\
\text { casing may be perforated or } \\
\text { slotted so that water may enter } \\
\text { the well, or a screen whose } \\
\text { openings are sized to match the } \\
\text { grain size of the water-bearing } \\
\text { material may be installed. }\end{array}$ & 34 & $\begin{array}{l}\text { Expensive construction. May obtain water } \\
\text { from many zones at greater depths. } \\
\text { Generally safe from contamination by } \\
\text { surface water if the casing is not per- } \\
\text { forated or screened in the first } 50 \text { to } \\
60 \text { feet, and the surface casing is grouted. }\end{array}$ \\
\hline $\begin{array}{l}\text { Open-end casing } \\
\text { wells (drilled) }\end{array}$ & Domestic & $\begin{array}{l}\text { A steel casing, usually } 6 \text { to } 8 \\
\text { inches in diameter lines the } \\
\text { entire well bore. The well } \\
\text { obtains water only through the } \\
\text { open bottom of the casing. } \\
\text { Usually less than } 100 \text { feet deep. } \\
\text { but may be drilled to consid- } \\
\text { erably greater depths. }\end{array}$ & 2 & $\begin{array}{l}\text { Low to moderate cost of construction } \\
\text { depending on depth. Can obtain water } \\
\text { from only one water-bearing zone. } \\
\text { Generally safe from contamination from } \\
\text { surface water if greater than } 50 \text { or } 60 \\
\text { feet deep, and the surface casing is } \\
\text { grouted. }\end{array}$ \\
\hline
\end{tabular}




\section{Water Levels}

The upper surface of the ground water in the young valley fill in late July and early August in recent years is shown by the water-table contours in figure 17. Hydrographs in figure 18 indicate that water levels annually return to approximately the same upper limit at this time of the year. This occurs when the water tables reaches the level of the drains. Although the annual-high water levels in the young valley fill have not changed significantly in recent years, there is considerable areal variation in the amplitude of annual-high water levels. Figure 19 shows the areal distribution of annual water-level fluctuations in the aquifer.

One significance of the annual fluctuation is that it can be used to estimate the amount of water that annually enters and leaves this aquifer under present conditions. Aquifers composed of sand and gravel commonly have about 20 percent of their volume occupied by water. Calculations made using this typical value (storage coefficient of 0.2) indicate that 120,000 acre-ft ( 148 million $\mathrm{m}^{3}$ ) of water annually enters and leaves the aquifer.

Data were insufficient to permit determining the water levels in wells tapping the aquifer prior to irrigation in the early $1900^{\circ} \mathrm{s}$. Some evidence exists for a substantial rise in water levels resulting from irrigation, but this evidence is highly subjective. When the Toppenish city well (10/20-3MI) was originally drilled in 1922 to a depth of $167 \mathrm{ft}(50.9 \mathrm{~m})$, water-bearing material was reported first at the $67-\mathrm{ft}(20.4 \mathrm{~m})$ depth; now, summer water levels are within $16 \mathrm{ft}(4.9 \mathrm{~m})$ of land surface. More convincing evidence is that shown by the historic relations of inflow to outflow in the diversion and drains during the development of the present irrigation system. During the period 1910-31, about 1.3 million acre-ft (1.6 billion $\mathrm{m}^{3}$ ) of water ( $\left.\mathrm{p} .33\right)$ apparently entered into storage in the young valley fill, though some of this total probably entered irrigated areas underlain by the old valley fill. If a storage coefficient of 0.2 is assumed, this quantity of water would be equivalent to an average water-level rise of approximately $50 \mathrm{ft}(15.2 \mathrm{~m})$ over about 130,000 acres (526 million $\mathrm{m}^{2}$ )-the approximate area presently irrigated. Although these calculations are not precise, they nevertheless account for a substantial rise in water levels that apparently took place during this time. 


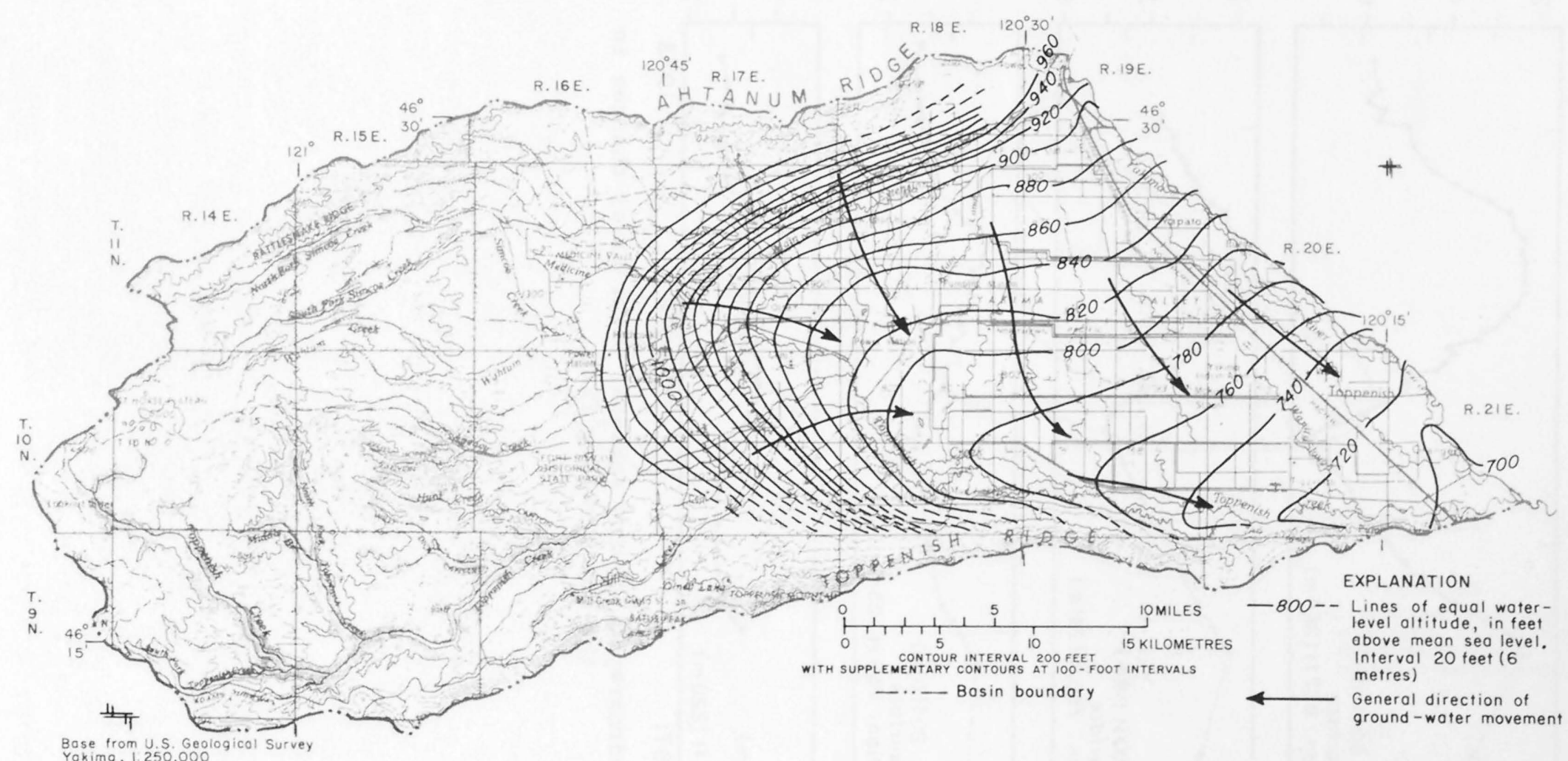

FIGURE 17.--Average July and August water-table altitudes in wells that tap the unconfined aquifers in the young and old valley fills. 


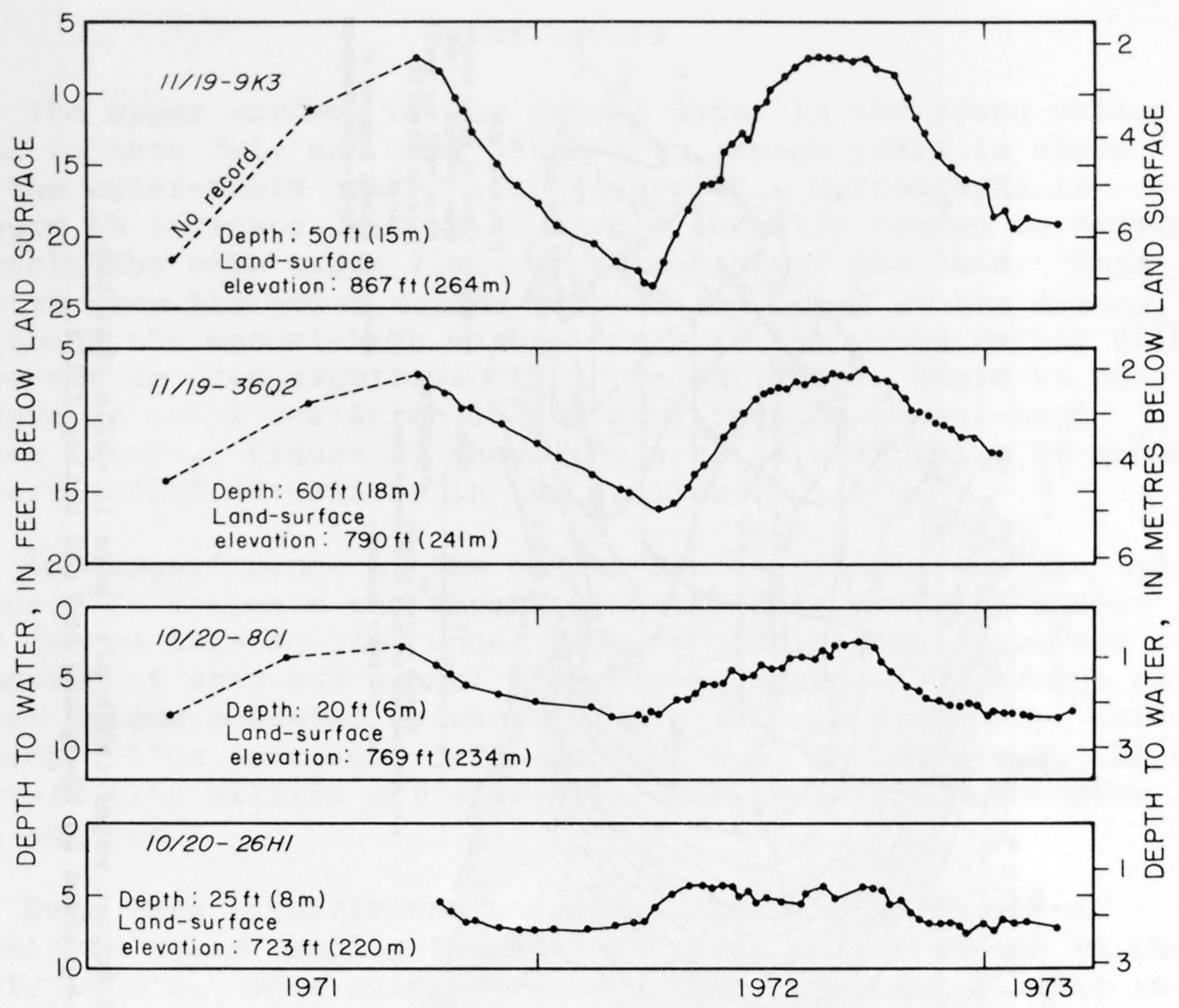

FIGURE 18.--Hydrographs showing seasonal water-level changes in the young valley fill. 


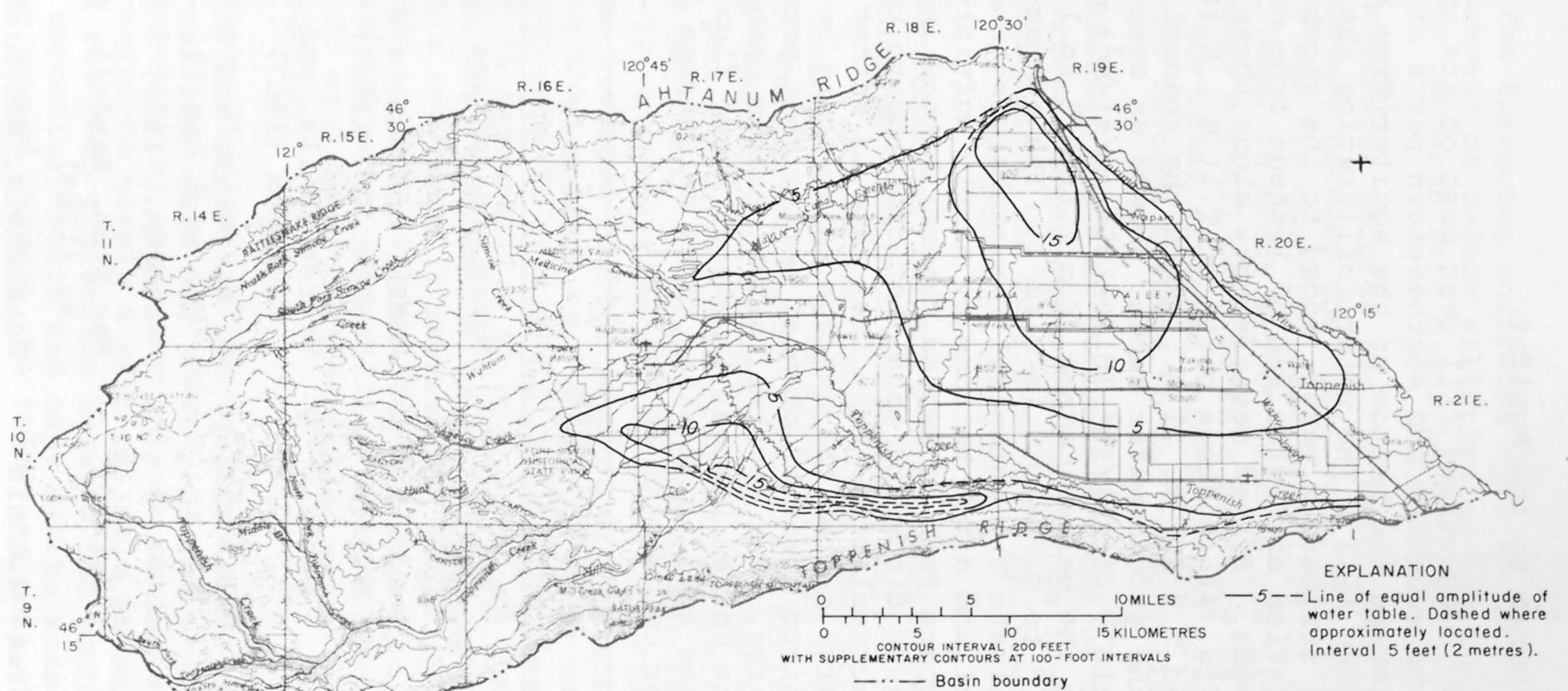

Bose trom 4.5 . Geological Survey

FIGURE 19.--Annual range in water-table fluctuations in the young valley fill and in the unconfined zone of the old valley fill. 
Water enters the young valley fill over most of its upper surface, except in the southern and southeastern parts of the basin, where water enters the bottom of the aquifer from the underlying older valley fill. The water infiltrating the surface is primarily irrigation water, added to the ground water through application on fields and by leakage from canals, ditches, and streambeds. Paired measurements along three reaches of canals (fig. 4) in those parts of T.11 N., R.18 E., T.11 N., R.19 E., and T.9 N., R. 21 E., where the channel bottoms were above the ground-water table, showed an average rate of loss of $1.5 \times 10^{-5}(\mathrm{ft} / \mathrm{s}) / \mathrm{ft}^{2}\left[0.46 \times 10^{-5}(\mathrm{~m} / \mathrm{s}) / \mathrm{m}^{2}\right]$ of channel bottom, with the values ranging from $1.1 \times 10^{-5}$ to $1.7 \times 10^{-5}$ $(\mathrm{ft} / \mathrm{s}) / \mathrm{ft}^{2}\left[0.34 \times 10^{-5}\right.$ to $\left.0.52 \times 10^{-5}(\mathrm{~m} / \mathrm{s}) / \mathrm{m}^{2}\right]$. The average value might be used to evaluate the potential for recharging the aquifer through canal and ditch bottoms by simply multiplying the number by the square feet of wetted channel bottom in an area. However, because ditch and canal bottoms tend to become sealed due to silt accumulation, this loss rate is rather low. In designing a recharge system the average value could be used to determine the minimum areas of channel bottom that provide given rates of recharge. For several natural stream channels in other parts of the United States, in places where flow variations prevent the buildup of silt, rates of seepage loss have been measured or calculated as follows:

\begin{tabular}{|c|c|c|}
\hline River & $\begin{array}{l}\text { Seepage loss } \\
{\left[(f t / s) / f t^{2}\right]}\end{array}$ & Reference \\
\hline $\begin{array}{l}\text { Arkansas River } \\
\text { in Colorado }\end{array}$ & $\begin{array}{l}2.17 \times 10^{-5} \\
2.635 \times 10^{-5}\end{array}$ & Moore and Jenkins (1966) \\
\hline $\begin{array}{l}\text { Little Plover River } \\
\text { in Wisconsin }\end{array}$ & $\begin{array}{l}4.55 \times 10^{-5} \\
6.2 \times 10^{-5}\end{array}$ & $\begin{array}{c}\text { Weeks, Ericson, and } \\
\text { Holt, Jr. (1965) }\end{array}$ \\
\hline Miami River in Ohio & $6.38 \times 10^{-6}$ & $\begin{array}{l}\text { Walton, Hills, and } \\
\text { Grundeen (1967) }\end{array}$ \\
\hline $\begin{array}{l}\text { Walla Walla River in } \\
\text { Washington }\end{array}$ & $1.55 \times 10^{-5}$ & $\begin{array}{l}\text { R. A. Barker and R. D. } \\
\text { Mac Nish (written } \\
\text { commun., 1974) }\end{array}$ \\
\hline $\begin{array}{l}\text { Chemung River in } \\
\text { New York }\end{array}$ & $3.1 \times 10^{-5}$ & $\begin{array}{l}\text { Mac Nish, Randall, and } \\
\mathrm{Ku} \mathrm{(1969)}\end{array}$ \\
\hline $\begin{array}{l}\text { Potowamut-Wickford area } \\
\text { in Rhode Island }\end{array}$ & $2.63 \times 10^{-5}$ & $\begin{array}{c}\text { Rosenshein, Gonthier, } \\
\text { and Allen (1968) }\end{array}$ \\
\hline
\end{tabular}


The foregoing indicates that if methods were employed to prevent or reduce siltation of the channel beds the seepage or recharge rate might be doubled.

Diversion records for the Main Canal show that the difference between the total water diverted from the Yakima River and the quantity passing points of diversion from the Main Canal is about 21,000 acre-ft (26 million $\mathrm{m}^{3}$ ) a year. Although a small part of this quantity is lost to evaporation from the canal surfaces, about 20,000 acre-ft ( 25 million $\mathrm{m}^{3}$ ) is lost through seepage to the young valley fill aquifer.

Another means of evaluating recharge rates is to compare the irrigated acreage with the change in storage in this aquifer during the period March-July, when the young valley fill becomes saturated each year.

Approximately 78,000 acres (316 million $\mathrm{m}^{2}$ ) are irrigated in the area underlain by the young valley fill east of the Main Canal and Harrah Drain. The quantity of water going into storage annually is about 120,000 acre-ft (148 million $\mathrm{m}^{3}$ ), mostly during March-June. This is a minimum estimate because it is based on the assumption that no water is discharged from this part of the aquifer from either drains or subsurface flow; certainly, both do occur. Based on records for the period 1969-72, a comparison of the annual diversion of the Main Canal (which averaged 633,000 acre-ft or 780 million $\mathrm{m}^{3}$ per year during that period) to that diverted up to July 15 (average 356,000 acre-ft or 439 million $\mathrm{m}^{3}$ ) implies that by mid-July about 56 percent $(2.5 \mathrm{ft}$ or $0.76 \mathrm{~m}$ ) of the average annual $4.5 \mathrm{ft} /$ acre application of irrigation water had been made. If this inference is correct, it would indicate that about 200,000 acre-ft $\left(247\right.$ million $\mathrm{m}^{3}$ ) of water had been applied to the 78,000 acres ( 316 million $\mathrm{m}^{2}$ ) and that about 60 percent $(1.5 \mathrm{ft}$ or $0.46 \mathrm{~m})$ of the applied water had infiltrated into the aquifer.

Water also enters the aquifer in its southeastern part (fig. 15) and from the underlying old valley fill aquifer. The quantity of water may only be estimated, however, as no data exist to permit a more reliable accounting. Figure 20 shows the head difference between the young and old valley fill deposits. South and east of the zero line, water is moving upward through the finer sediment that separate the water-bearing zones of the young and old valley fill deposits. 


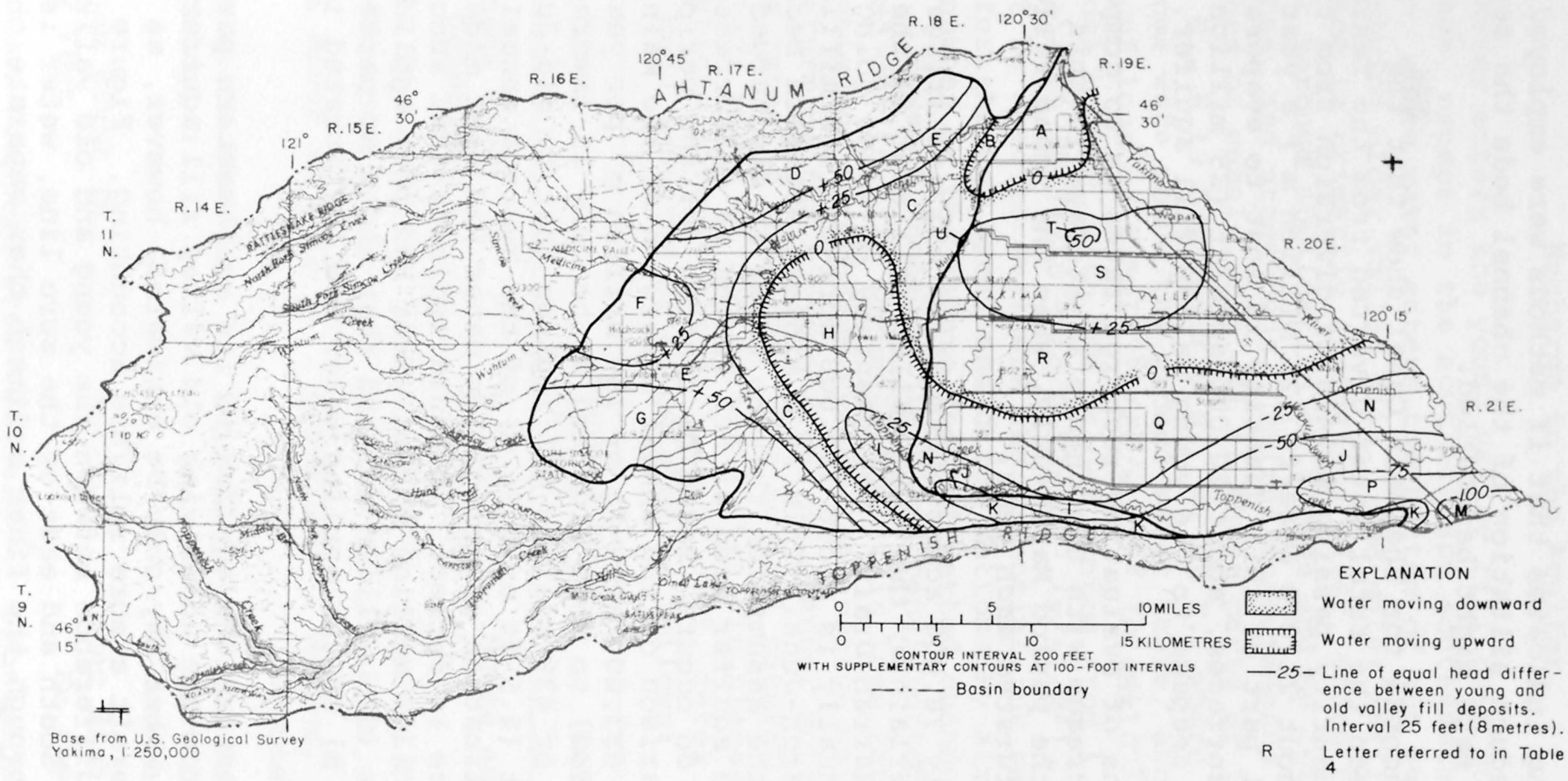

FIGURE 20.--Generalized differences between hydraulic heads in artesian zones of the old valley fill and the average water table shown in figure 17. 
Driller's logs of the deeper wells in the area of the young valley fill indicate that the combined thickness of clay or clayey sediment averages about $75 \mathrm{ft}(23 \mathrm{~m})$ being as much as $100 \mathrm{ft}(30 \mathrm{~m})$ in the northern part of the area and as little as $50 \mathrm{ft}(15 \mathrm{~m})$ in the southeastern corner of the area. Assuming that the vertical conductivity of these clay beds is $0.1 \times 10^{-6}(\mathrm{ft} / \mathrm{s}) / \mathrm{ft}^{2}\left[0.03 \times 10^{-6}(\mathrm{~m} / \mathrm{s}) / \mathrm{m}^{2}\right]--$ near the lower limit of conductivity described by Johnson (1964) as characterizing mixtures of silt and clay--an estimate can be made of the quantity of water moving between the young and old valley fill units.

Table 4 summarizes the volume of water moving vertically between these two aquifers, and shows that the water entering the young valley fill vertically from the old valley fill totals about 84,000 acre-ft (104 million $\mathrm{m}^{3}$ ) per year, with almost all of this water entering the aquifer south of State Highway 220 (Fort Road). An additional 11,000 acre-ft (135 million $\mathrm{m}^{3}$ ) enters the young valley fill from the old valley fill via lateral seepage along their western boundary.

\section{Discharge From the Aquifer}

Once having entered the young valley fill the water moves downgradient until it reaches a point or area of discharge from the aquifer. The configuration of the water-level contours in figure 17 indicate that the general direction of water movement is to the south and southeast, with the primary discharge area from the aquifer being along Toppenish Creek at the foot of Toppenish Ridge. In 1911, the measured discharges of Toppenish Creek near White Swan and at Alfalfa showed a gain of more than 77,000 acre-ft (95 million $\mathrm{m}^{3}$ ) between the two sites. Although some of this was undoubtedly return flow from surface drains, most of that gain represented a discharge from the aquifer. In the area along Toppenish Creek, the proximity of water levels to land surface allows plant roots to tap water directly from the shallow aquifer. Thus, water is removed from the aquifer both by direct discharge to stream channels and by transpiration by vegetation in the area. 
TABLE 4.--Ground-water flow between water-table zones in the young and old valley fill aquifers and artesian zones in the old valley fill aquifer, by areas

\begin{tabular}{lllll} 
Area shown in figure 22 & $\begin{array}{c}\text { Area } \\
(\mathrm{mi} 2)\end{array}$ & $\begin{array}{c}\text { Average } \\
\text { head } \\
\text { differ- } \\
\text { ence(ft) }\end{array}$ & $\begin{array}{l}\text { Thickness clay } \\
\text { layer (ft) }\end{array}$ & $\begin{array}{l}\text { Flow } \\
\text { (acre- } \\
\mathrm{ft} / \mathrm{yr})\end{array}$ \\
\hline
\end{tabular}

Areas where water moves upward to water-

table zones:

In young valley fill:

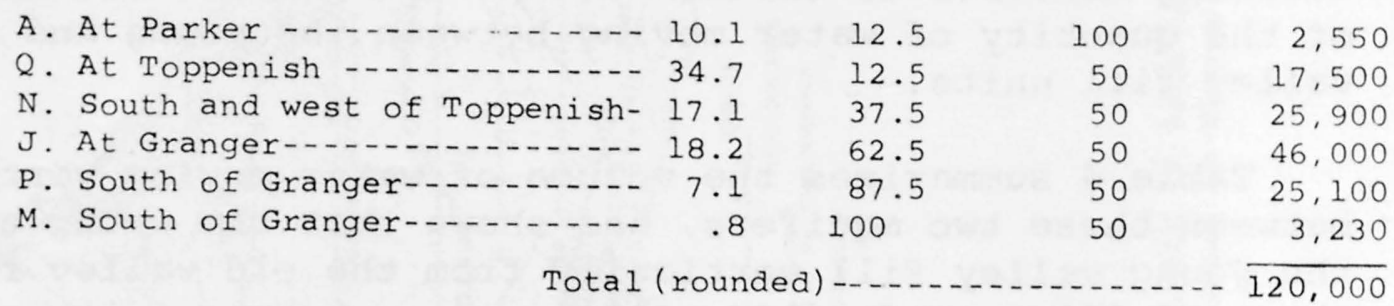

In old valley fill:
B. West of Parker.......... 2.0
12.5
200
252
H. At Brownstown-......... 29.4
12.5
200
3,710
I. South and southeast of
Brownstown-........... 8.1
37.5
200
3,070
K. South of Toppenish Creek--- 3.1
62.5
200
1,960
Total (rounded)

Areas where water moves downward from

water-table zones:

In young valley fill:
R. South and East of Harrah--- 57.4
12.5
100
14,500
S. At Wapato
37.5
100
20,900
T. West of Wapato............ 6
50
100
590
Total (rounded)
36,000

In old valley fill:
U. North of Harrah-......... .2
37.5
200
200
76
C. North and west of Brownstown 27.3
12.5
100
3,440
D. North of the unit \#l pump canal-................. 16.2

$\begin{array}{ll}50 & 100 \\ 37.5 & 100 \\ 12.5 & 100 \\ 50 & 100\end{array}$
16,400
E. At White Swan-..... 25.6
100
19,400
F. West of White Swan-.....- 8.5
100
2,150
G. South of White Swan-..... 25.4
Total (rounded)
25,600
67,000

Note: Formula for calculation.

Flow $\left(\right.$ acre-ft) $=$ area $\left(\right.$ in $\left.f t^{2}\right) x$ average head difference (in $\left.f t\right)$

$$
\times \frac{0.1 \times 10^{-6} \mathrm{ft} / \mathrm{s}}{\text { clay thickness (in ft) }} \times 724 \text {. }
$$


Perhaps the most significant method of discharge at the present time is that which occurs from the artificial drains that web the aquifer surface. When the aquifer becomes saturated by mid-July, any water from irrigation or rainfall in excess of that required for plant growth seeps into these drains. In recent years, the quantity of water leaving these drains averaged about 344,000 acre-ft (424 million $\left.\mathrm{m}^{3}\right)$. No determination can be made at this time of the ratio of the quantity that moved through the aquifer to that leaving the area as surface runoff.

As a result of the difference in heads between the old and young valley fills (fig. 20), some water discharges from the young valley fill in its north-central part to the old valley fill. Table 4 shows this quantity is estimated to be about 36,000 acre-ft $\left(44\right.$ million $\mathrm{m}^{3}$ ) per year.

Another method of discharge from the young valley fill is through pumping from wells; in 1974 about 5,900 acre-ft ( 7.3 million $\mathrm{m}^{3}$ ) was pumped annually: Although this pumpage represents a withdrawal from the aquifer, some pumped water percolates from the land surface back to this aquifer. Of the total pumpage, only that amount used consumptively (evapotranspiration) or exported from the aquifer surface by drains or by the shipment of crops is actually lost from the system.

Another method of discharge from the aquifer is groundwater seepage to the Yakima River. The amount of direct discharge to the Yakima River is much smaller than the discharge to Toppenish Creek, as can be inferred from figure 17. When the aquifer is saturated, the arrows indicating the direction of water movement in the aquifer closely parallel the Yakima River itself, implying there is very little net exchange between the aquifer and the river except in the southeastern corner of the basin where converging arrows imply significant discharge. During the part of the year when the aquifer is less than full, the water in the Yakima River channel moves into the young valley fill, at least in the northernmost two-thirds of its reach along the reservation. The net, yearly exchange of water between the aquifer and the Yakima River is included with the estimated flow from miscellaneous surface drains and totals 97,000 acre-ft (120 million $\mathrm{m}^{3}$ ).

An additional 3,000 acre-ft ( 4 million $\mathrm{m}^{3}$ ) a year is estimated to leave the young valley fill as underflow (beneath the Yakima River) in the southeast corner of the Toppenish Creek basin. 


\section{Present Ground-Water Development}

The present (1974) pumpage from this aquifer is about 5,900 acre-ft $\left(7.3\right.$ million $\mathrm{m}^{3}$ ) annually (table 2). For an aquifer with such a high degree of hydraulic connection with surface-water bodies, high-specific-capacity wells, and a water level so close to land surface, this represents a very low level of development.

A variety of well types withdraw water from this aquifer. Table 3 summarizes the nature of construction and efficiency in terms of specific capacities of the various types of wells. Although the total pumpage from this aquifer is small, the points of withdrawal are numerous. Many domestic water supplies are obtained from this unit. Figure 14 includes information on the aquifers tapped by selected wells.

\section{Potential for Further Development}

Although the water-yielding characteristics of the young valley fill aquifer would permit extensive ground-water development anywhere the aquifer is present, the geometry of the aquifer suggests it would be best utilized by development in the central and southern parts of the aquifer. Stream water presently diverted to areas underlain by the young valley fill is adequate to irrigate its entire surface, although some augmentation by ground water may be necessary due to problems of surface-water distribution. If the present diversion of surface water to this aquifer surface were reduced in order to provide water elsewhere, the reduction could be made up by ground water pumped from the aquifer.

Present irrigation practices satisfy plant needs and prior to mid-July each year there is a surplus of 120,000 acre-ft (148 million $\mathrm{m}^{3}$ ) of water in the northern and central parts of the aquifer. This excess irrigation water goes into storage in the young valley fill.

Although a digital computer model would be required for a more detailed evaluation of the interaction of surfacewater drains and the aquifer, it is reasonable to assume that as much as 120,000 acre-ft (148 million $\mathrm{m}^{3}$ ) could be diverted from the Main Canal to other areas, and this amount of diversion could be replaced by ground-water pumpage to laterals 2, 3, and 4. Properly constructed wells in the young valley 
fill could pump about $1,350 \mathrm{gal} / \mathrm{min}(3 \mathrm{ft} / \mathrm{s})$ or $85 \mathrm{l} / \mathrm{s}$ with about $30 \mathrm{ft}(9 \mathrm{~m})$ of drawdown, and, with a minimum well spacing of one-half mile $(0.8 \mathrm{~km})$ along the laterals, there should be minimal interference problems. As the water levels in this aquifer are currently below the water levels in the laterals, lowering the water levels in the aquifer probably will not significantly increase leakage from the laterals. During the irrigation season water-level declines probably will not exceed $100 \mathrm{ft}(30 \mathrm{~m})$, as under current irrigation practice 60 percent of the applied water in the north-central parts of the young valley fill area seeps into the aquifer. The effect of this management scheme would be to reduce the ground-water outflow to drains. The amount of reduction in drain flow could approach the amount of pumpage.

The good hydraulic connection between the surface water and this aquifer system calls for some caution in water-use planning. Preliminary data from a study of ground-water quality (M. O. Fretwell, oral commun., 1974) shows that concentrations of dissolved nitrogen compounds in this aquifer are higher than in other aquifers in this area, and higher than in similar aquifer units in areas that are less agriculturally developed. Although concentrations of dissolved solids are presently well within the accepted limits of desirable water quality, the potential exists for persistent pesticide and fertilizer compounds to enter the aquifer and locally exceed standards set for these compounds by the Environmental Protection Agency (1972). As this aquifer has great potential for supplying large yields suitable for irrigation use, and because of the presence of suitable soils, the emphasis on development in this part of the area will likely be toward agriculture. Domestic and public supplies could be designed to tap deeper aquifers for their supplies to avoid any future contamination resulting from agricultural practices. 


\section{old Valley Fill}

As shown by the diagrammatic well logs in figure 15, old valley fill (largely comprised of the Ellensburg Formation) is within $50 \mathrm{ft}(15 \mathrm{~m})$ of land surface in the western part of the lowland and overlain by the young valley fill in the eastern part. To the west, it thins abruptly where the basalt forming the uplands rises toward the land surface. Near the center of the lowland of the basin the thickness of the old valley fill may be as much as $1,000 \mathrm{ft}(305 \mathrm{~m})$. This deposit yields water to wells over the entire lowland of the Toppenish Creek basin.

\section{Aquifer Characteristics}

The old valley fill is composed primarily of semiconsolidated silt, sand, gravel and clay of the Ellensburg Formation. The proportions of the various lithologic components of this unit vary widely both vertically and horizontally, as indicated by selected well logs in appendix IV. In the part of the area where the fill is within $50 \mathrm{ft}(15 \mathrm{~m})$ of land surface (fig. 15), the upper part of the aquifer is under water-table (unconfined) conditions. Water in deeper zones in this area and in the area farther to the east--under the young valley fill--is under artesian pressure.

Yields of efficiently constructed wells tapping old valley fill are as much as $1,500 \mathrm{gal} / \mathrm{min}$ (95 l/s), and specific capacities range from 3 to $300(\mathrm{gal} / \mathrm{min}) / \mathrm{ft}[0.6$ to $60(1 / \mathrm{s}) / \mathrm{m}]$ of drawdown for wells that in most cases only partly penetrate the aquifer. An average specific-capacity value for this unit would be misleading as very few wells are open to all the productive zones. Specific capacities of wells open to most of the gravel and sand units in the aquifer probably average about $30(\mathrm{gal} / \mathrm{min}) / \mathrm{ft}[6(1 / \mathrm{s}) / \mathrm{m}]$ of drawdown. 


\section{Water Levels}

The old valley fill has both water-table ana artesian zones with differing water levels. Figure 17 shows average water levels in July and August in the water-table zones where the aquifer is within $50 \mathrm{ft}(15 \mathrm{~m})$ of land surface, and figure 21 shows the water levels in March 1972 in the artesian zones of the aquifer.

There has been some decline in heads in the artesian zones of this aquifer, as observed in well 11/17-1Ql, which had a measured water level of $30 \mathrm{ft}(9.1 \mathrm{~m})$ below land surface in 1961 and almost $89 \mathrm{ft}(27.1 \mathrm{~m})$ below land surface in 1972 . The moderate amount of pumpage from this aquifer is not sufficient to explain the large water-level declines of more than $50 \mathrm{ft}(15 \mathrm{~m})$ in some wells tapping this artesian zone. The declines are most likely due to the pumping from the aquifer in the underlying basalt; this has changed the relation of the original heads in these two aquifers and caused water to move into the underlying basalt. This is discussed further on page 65 .

\section{Recharge to the Aquifer}

The old valley fill receives recharge primarily in its western part, where the water-table zones receive infiltrating water from precipitation and irrigation water applied to the land surface. Of the 298,000 acre-ft ( 370 million $\mathrm{m}^{3}$ ) of water applied to the aquifer surface in this area each year-from precipitation and from surface- and ground-water irrigation--about 193, 000 acre-ft (238 million $\mathrm{m}^{3}$ ) is estimated to be consumed by plants or evaporated from the surface. The remaining water enters the aquifer or runs directly off into surface drains. The water entering the aquifer contributes an estimated 58,000 acre-ft $\left(72\right.$ million $\left.\mathrm{m}^{3}\right)$ per year to recharge entering the lower artesian zones of the aquifer and the remainder is discharged to streams and drains on the surface of the aquifer. Although the quantity of water circulating through the shallow zones of the aquifer to discharge to streams and the quantity of direct surface runoff are not differentiated here, the combined total of the two components is currently about 47,000 acre-ft (58 million $\mathrm{m}^{3}$ ) per year. 


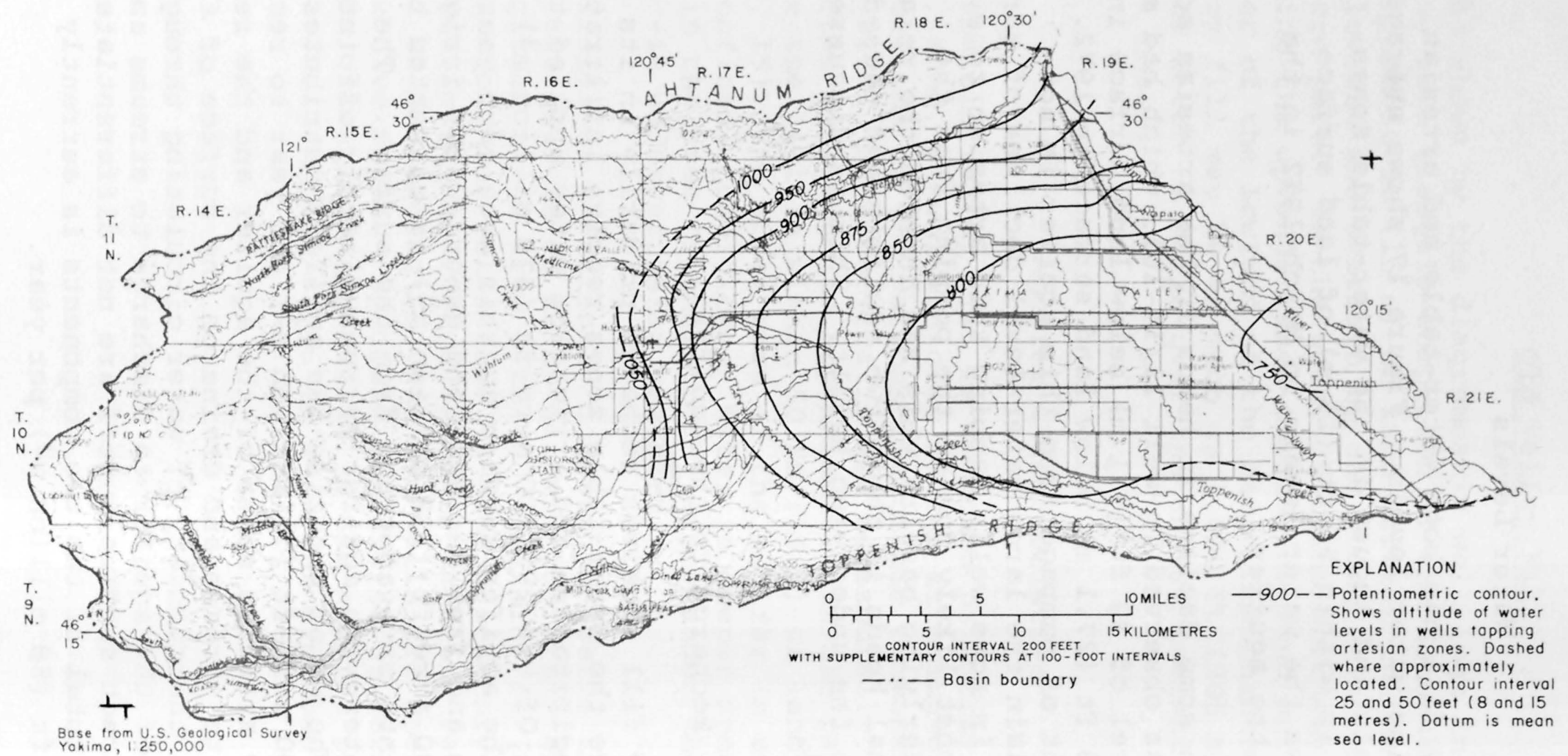

FIGURE 21.--Contours showing water levels in wells tapping artesian zones in the old valley fill, March 1972. 
In the southeastern part of the area the water-level relation between the aquifers in the old valley fill and in the underlying basalt (fig. 22) indicates that recharge enters the old valley fill from the basalt in the area within positive contours. The thickness of the confining layer separating the basalt and old valley fill aquifers ranges from more than $300 \mathrm{ft}(91 \mathrm{~m})$ in Medicine Valley to an estimated $50 \mathrm{ft}$ $(15 \mathrm{~m})$ in the southeastern part of the basin. The thickness of the layer in Medicine valley is inferred from the records of water levels and flow in the Medicine Valley test well $(11 / 16-15 \mathrm{Kl})$. As the test well was being drilled, water levels remained very near land surface (1,285-ft or 391-m elevation), but the yield of the well steadily increased with depth to $355 \mathrm{ft}(108 \mathrm{~m})$. From that depth to $687 \mathrm{ft}(209 \mathrm{~m})$ the water level remained the same and the yield of the well did not change significantly. When the well was at the 687-ft (209-m) depth the water level dropped to $437 \mathrm{ft}(133 \mathrm{~m})$ below land surface, or to an elevation of $848 \mathrm{ft}(258 \mathrm{~m})--a$ level compatible with the heads in the main basalt aquifer east of Medicine Valley. The predominance of fine materials in the old valley fill in the western part of the basin decreases and coarser materials occur toward the east, and the thickness of the confining layer is, thus, estimated to be as little as $50 \mathrm{ft}(15 \mathrm{~m})$ in the southeastern part of the basin. However, no wells penetrate to the basalt in this area at present (1974), hence the thickness of the confining layer can only be estimated.

The hydraulic conductivity of the confining layer can only be estimated as no means of measuring this value are available. Owing to the presence of some dense basalt zones in this confining layer its conductivity was assumed to be one-half that of the confining layer separating the old and young valley fill. Based on these assumptions, table 5 lists the distribution of flow between the old valley fill and the basalt aquifer. The table shows that about 94,000 acre-ft ( 116 million $\mathrm{m}^{3}$ ) per year of recharge enters the old valley fill from the basalt in the southeastern part of the basin. 


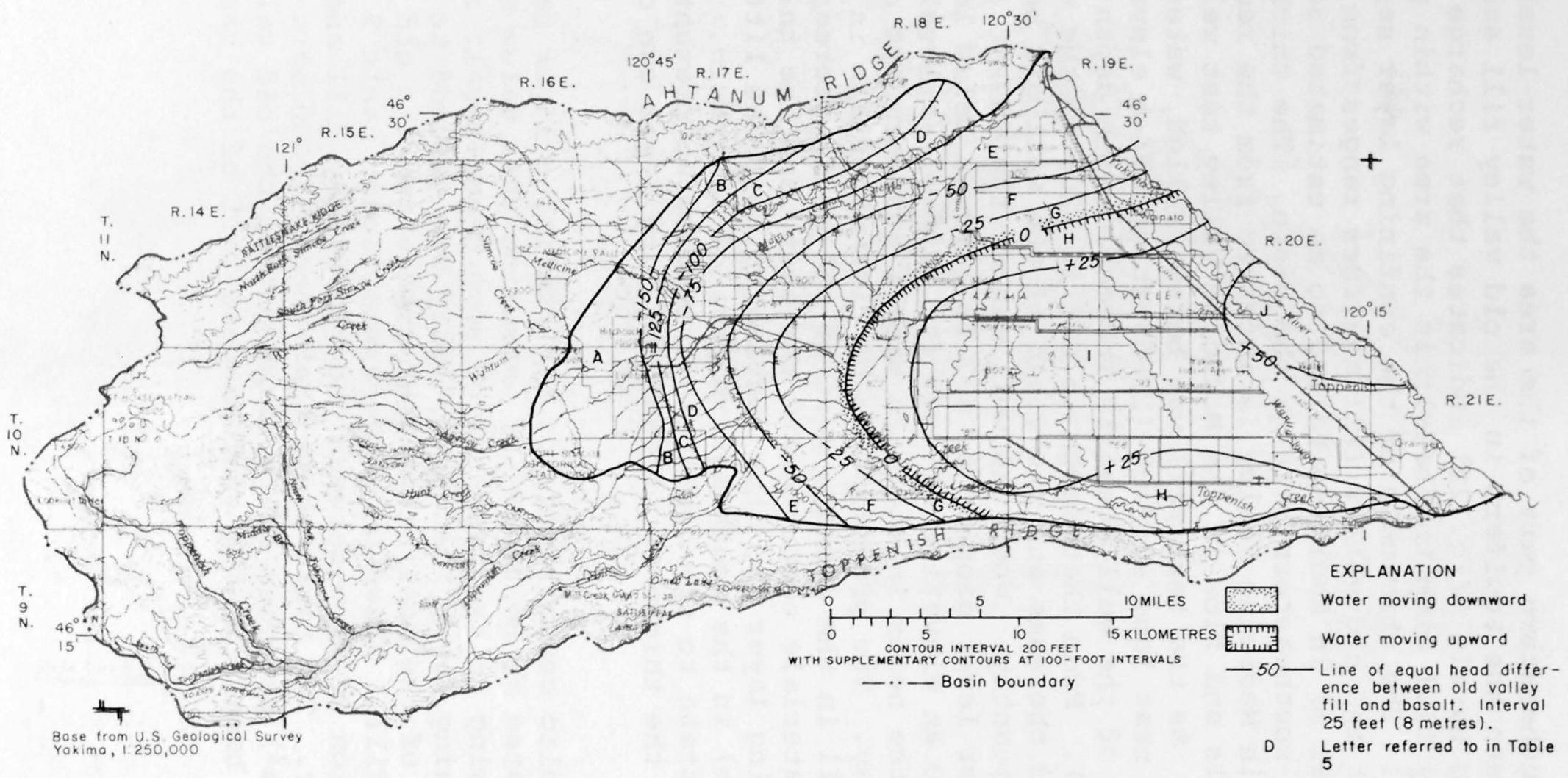

FIGURE 22.--Head differences between aquifers in the basalt and in the old valley fill, March 1972 . 
TABLE 5.--Ground-water flow between the old valley fill and basalt aquifers, by areas

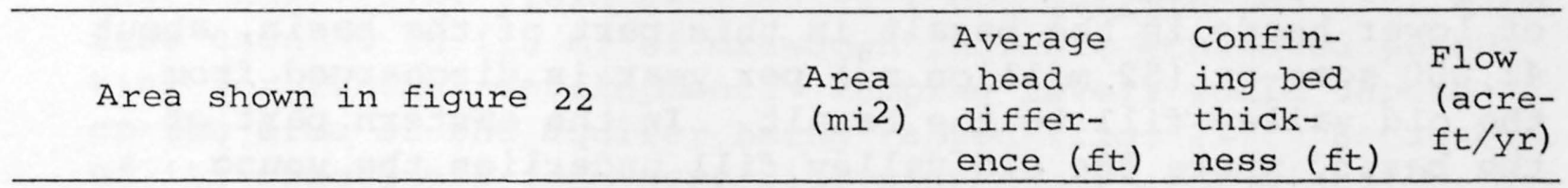

Areas where water is moving

downward:
A. West of White Swan-..-- 23.9
150
300
12,100
B.
7.9
137.5
300
3,650
C. -
112.5
300
5,040
D. -.--do-n 16.6
87.5
300
4,880
E. At White Swan-.... 37.0
62.5
300
7,770
F. At Olney Flat_...... 32.2
37.5
200
6,100
G. At Brownstown-... 25.1
12.5
150
$\underline{2,110}$
Total (rounded)
42,000

Areas where water is moving upward:
$\mathrm{H}$. West of Harrah- 48.5
12.5
100
6,110
I. Harrah-Granger-Toppenish
area-....... 99.5
J. North of Toppenish-_..-- 11.5
37.5
55
50
75,500
Total (rounded)
50
12,800
(19,000

Note: Formula for calculation.

Flow to old valley $f i l l=$ area $\left(f t^{2}\right) \times$ average head difference (in $f t$ ) (acre-ft)

$$
\times \frac{0.5 \times 10^{-7} \mathrm{ft} / \mathrm{s}}{\text { confining bed thickness (in ft) }} \times 724 \text {. }
$$




\section{Discharge from the Aquifer}

In the western part of the basin the old valley fill is being recharged at its upper surface at the same time water is being discharged to the underlying basalt. As a result of lower heads in the basalt in this part of the basin, about 42,000 acre-ft ( 52 million $\mathrm{m}^{3}$ ) per year is discharged from the old valley fill to the basalt. In the eastern part of the basin, where the old valley fill underlies the young valley fill, about 84,000 acre-ft (104 million $\mathrm{m}^{3}$ ) per year discharges vertically from the former to the latter (table 4). An additional 11,000 acre-ft $\left(14\right.$ million $\left.\mathrm{m}^{3}\right)$ is estimated to flow laterally into the young valley fill from the old valley fill where they abut along their common boundary. Also, as indicated by the contours in figure 21 , water is discharged from the old valley fill as underflow (beneath the Yakima River). About 10,000 acre-ft ( 12 million $\mathrm{m}^{3}$ ) per year leaves the Toppenish Creek basin in this manner.

\section{Present Ground-Water Development}

The old valley fill yields approximately 6,500 acre-ft $\left(8\right.$ million $\mathrm{m}^{3}$ ) per year to wells in the basin. About 5,000 acre-ft ( 6 million $\mathrm{m}^{3}$ ) of this pumpage is in the area where this aquifer is overlain by the young valley fill. However, as many of the wells tapping this unit also obtain water from the young valley fill or the basalt, this pumpage must be considered a rough approximation. 
Additional development of the old valley fill aquifer is possible in most of the lowland parts of the basin. Wells which now (1974) yield as much as $1,000 \mathrm{gal} / \mathrm{min}$ (63 1/s) with less than $50 \mathrm{ft}(15 \mathrm{~m})$ of drawdown indicate continued potential for further development. Pumping levels would depend on the area of the aquifer being tapped (fig. 21). Because of its remoteness from surficial sources of contamination this aquifer can provide good-quality waterl that is unlikely to be affected by agricultural or other practices that introduce surficial contaminants. Currently (1974) an estimated 10,000 acre-ft (12 million $\mathrm{m}^{3}$ ) of water per year leaves the basin through this aquifer as underflow eastward beneath and beyond the Yakima River. Pumping in the eastern part of the aquifer could capture part of this discharge and reduce the discharge upward to the young valley fill. In view of the large expected yields and good-water quality, this aquifer represents a desirable water source for municipal and industrial, as well as irrigation, supplies.

\section{Basalt}

Basalt underlies the entire Toppenish Creek basin, being at the surface in the upland parts of the basin and within $50 \mathrm{ft}(15 \mathrm{~m})$ of land surface in the western part of the lowland. The maximum thickness of the basalt is unknown, but the minimum is about 2,000 ft $(610 \mathrm{~m}$ ) in this area (Foxworthy, 1962 ).

$I_{\text {The chemical quality of ground water in the Toppenish }}$ Creek basin is presently (1974) being evaluated. According to data collected in 1959 by Van Denburgh and Santos (1965, p. 90) the chemical analysis of a city of Toppenish municipalsupply well (10/20-9Al), which taps the artesian zone at the 792-863-ft (241-263-m) depth interval in the old valley fill in this area, indicates water of good quality, with a hardness of $42 \mathrm{mg} / \mathrm{l}$ (milligrams per litre), an iron concentration of $0.08 \mathrm{mg} / 1$, and a dissolved-solids concentration of $158 \mathrm{mg} / 1$. 


\section{Aquifer Characteristics}

Yields of wells tapping the basalt range from 45 to 2,200 $\mathrm{gal} / \mathrm{min}(2.8$ to $139 \mathrm{l} / \mathrm{s})$, with specific capacities ranging from less than 1 to $400(\mathrm{gal} / \mathrm{min}) / \mathrm{ft}[0.2$ to $83(1 / \mathrm{s}) / \mathrm{m}]$ of drawdown and averaging about $16(\mathrm{gal} / \mathrm{min}) / \mathrm{ft}[3.3(1 / \mathrm{s}) / \mathrm{m}]$ of drawdown. Water moves through the basalt in fractures and through rubbly interflow zones that occur between successive flow units. The lateral variations in interflow-zone distribution, coupled with the dominance of these zones in terms of water-yielding ability, make it nearly impossible to predict the effect of any single well on adjacent wells. However, the interflow zones are mutually interconnected to such a degree that long-term effects of any stress will be felt over a fairly large area. Long-term pumping from this aquifer has caused declines over a $400 \mathrm{mi}^{2}\left(1,036 \mathrm{~km}^{2}\right)$ area in the Toppenish Creek basin.

The bowl-shaped structure of the basalt in the Toppenish Creek basin is shown by the basalt-surface contours in figure 23, which were developed from a gravity survey by Robbins, Burt, and Gregg (1975).

The northern and southern sides of the basalt structural basin are much steeper than the western side, which slopes upward in the Cascade foothills. The basalt is sharply folded along the Ahtanum and Toppenish Ridges which, with the associated faulting often found in such structures, act as effective barriers to ground-water movement.

A smaller flexure which trends northeastward across the western part of the basin and separates Medicine Valley from the eastern lowlands was the subject of a more detailed study by drilling of the Medicine Valley test well (11/16-15Kl) . This structure is apparently shallow, and although it acts as a barrier to ground-water movement in the upper zones of the basalt, it shows no effect on ground-water movement at depth. The test well showed that the damming effect of the structure does not extend to the deeper zones, and water levels on both sides of the Medicine Valley structures are in close agreement. 


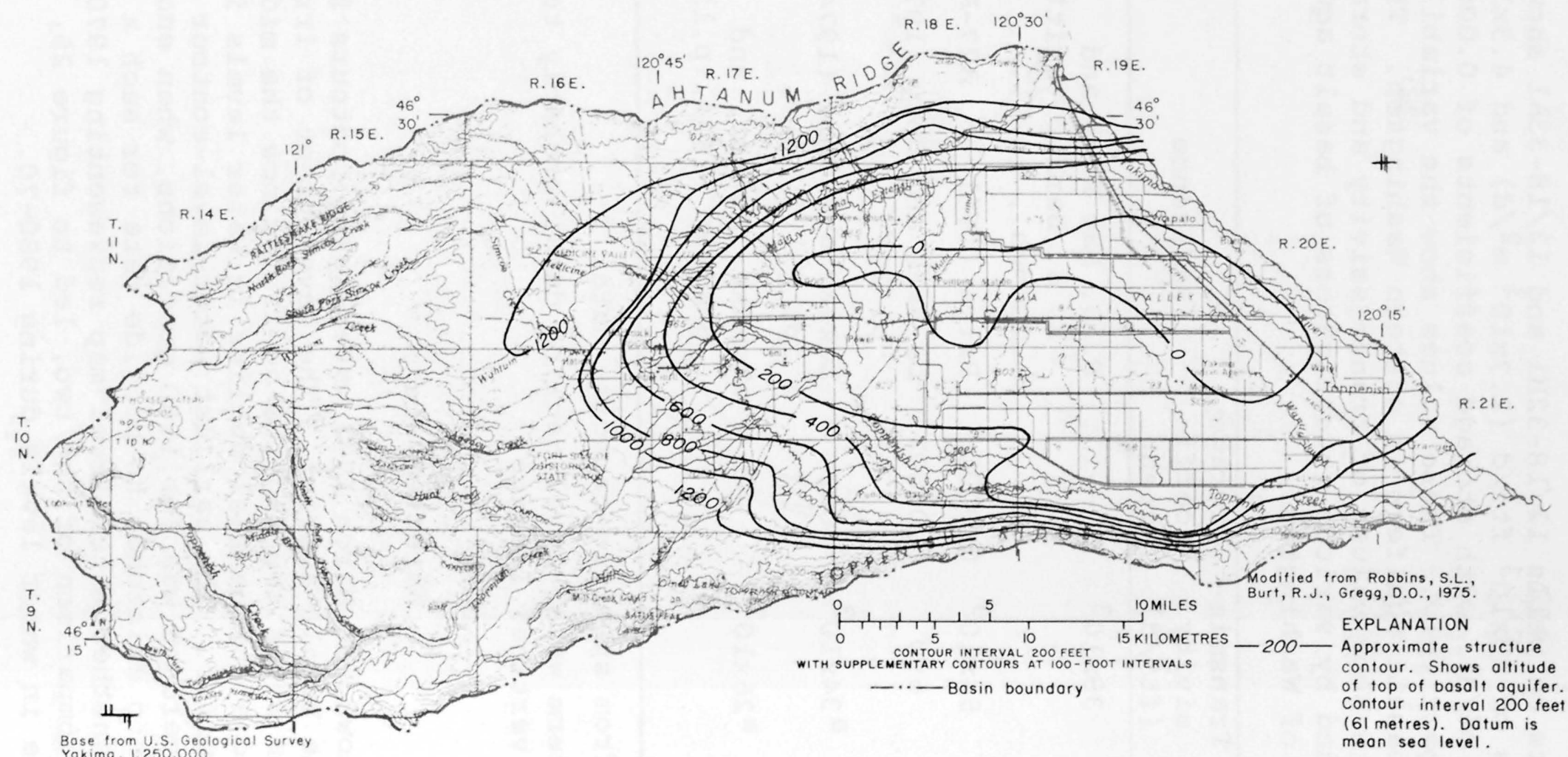

FIGURE 23.--Contours showing the generalized altitude of the upper surface of the basalt aquifer in the Toppenish Creek basin, as determined by gravity and aeromagnetic methods (Robbins and others, 1975). 
Aquifer tests on wells $12 / 18-32 \mathrm{Hl}$ and $12 / 18-33 \mathrm{Al}$ showed transmissivities of $29 \times 10^{3} \mathrm{ft}^{2} / \mathrm{d}\left(2.7 \times 10^{3} \mathrm{~m}^{2} / \mathrm{d}\right)$ and $4.3 \times 10^{3}$ $\mathrm{ft}^{2} / \mathrm{d}\left(0.40 \times 10^{3} \mathrm{~m}^{2} / \mathrm{d}\right)$, with storage coefficients of 0.00006 and 0.0002 , respectively. These values show the variability typical of the basalt aquifers in eastern Washington. The table below lists some values of transmissivity and storage coefficients found by various investigators of basalt aquifers in nearby areas of Washington.

\begin{tabular}{|c|c|c|c|}
\hline Area & $\begin{array}{l}\text { Transmis- } \\
\text { sivity } \\
\left(f t^{2} / d\right)\end{array}$ & $\begin{array}{l}\text { Storage } \\
\text { coeffi- } \\
\text { cient }\end{array}$ & Reference \\
\hline Walla Walla--.- & $38 \times 10^{3}$ & -- & $\begin{array}{l}\text { R. D. Mac Nish and } \\
\text { R. A. Barker (written } \\
\text { commun., 1974). }\end{array}$ \\
\hline Walla Walla-.-- & $54 \times 10^{3}$ & 0.0002 & Price (1961, p. A27-A28) \\
\hline Hanford--.---- & 690 & .00007 & $\begin{array}{l}\text { La Sala and Doty (1971, } \\
\text { p. 39). }\end{array}$ \\
\hline Odessa-......- & $a_{34 \times 10^{3}}$ & b. 002 & $\begin{array}{l}\text { Luzier and Burt (1974, } \\
\text { p. 25). }\end{array}$ \\
\hline $\begin{array}{l}\text { Columbia Basin } \\
\text { Irrigation } \\
\text { Project. }\end{array}$ & $a_{26 \times 10^{3}}$ & -- & $\begin{array}{l}\text { Tanaka, Hansen, and } \\
\text { Skrivan (1974, p.11). }\end{array}$ \\
\hline
\end{tabular}

Estimated from specific-capacity data.

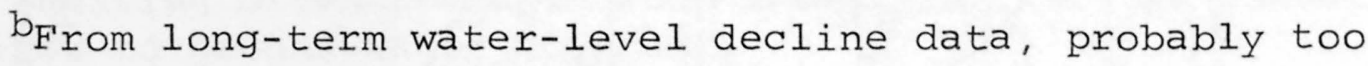
high because of vertical leakage.

\section{Water Levels}

Figure 24 shows the March 1972 water-level contours for wells tapping the basalt aquifer. The development of irrigation water from wells tapping the aquifer since the mid1950's has caused a substantial decline in water levels in parts of this aquifer. The earliest water-level-contour map that could be developed was for 1960 conditions, when enough wells had come into existence to provide data for such a map. Construction of another water-level map representing 1970 conditions, and comparison of the two, led to figure 25, which shows the decline in water levels during 1960-70. 


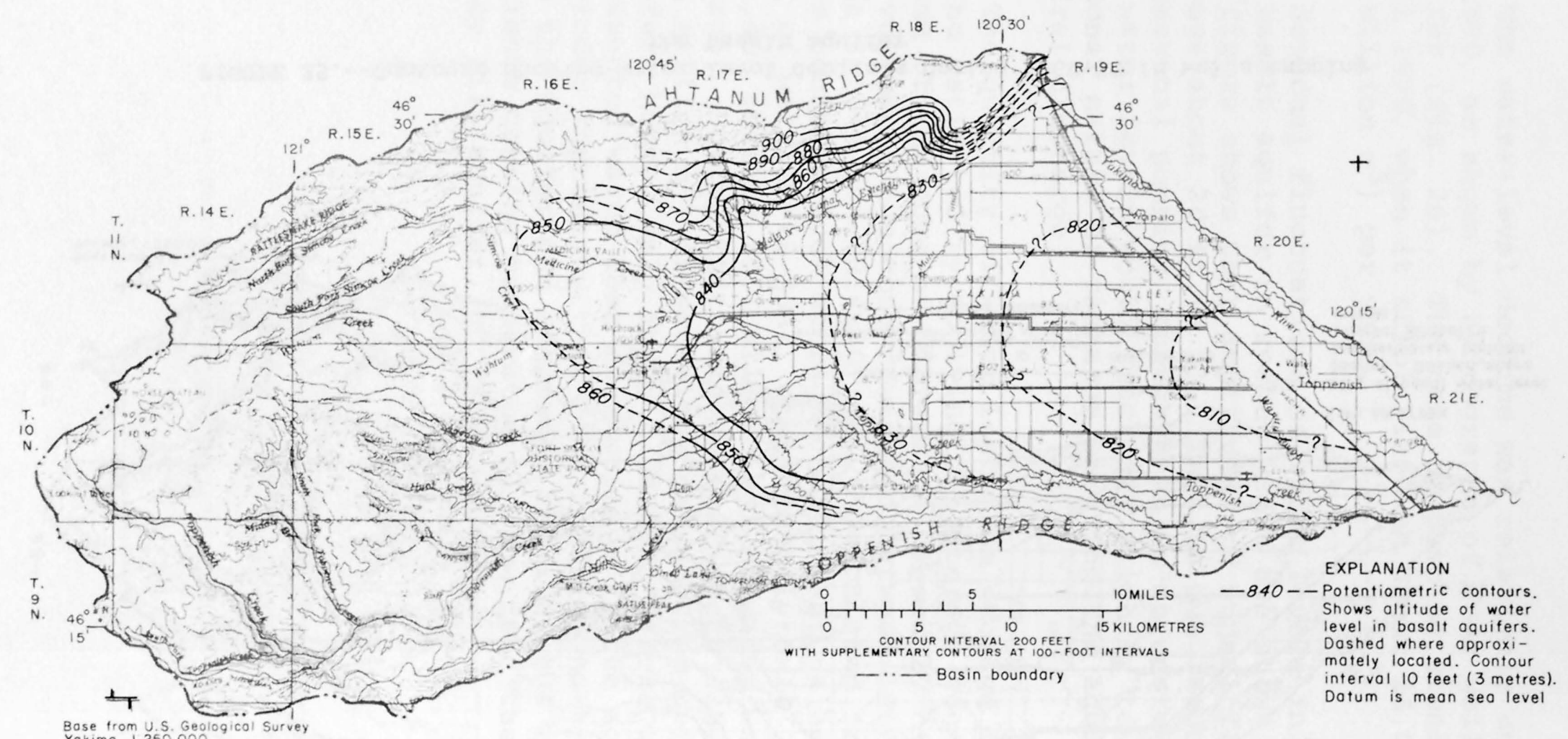

FIGURE 24.--Contours showing water levels in wells tapping basalt aquifers, March 1972. 


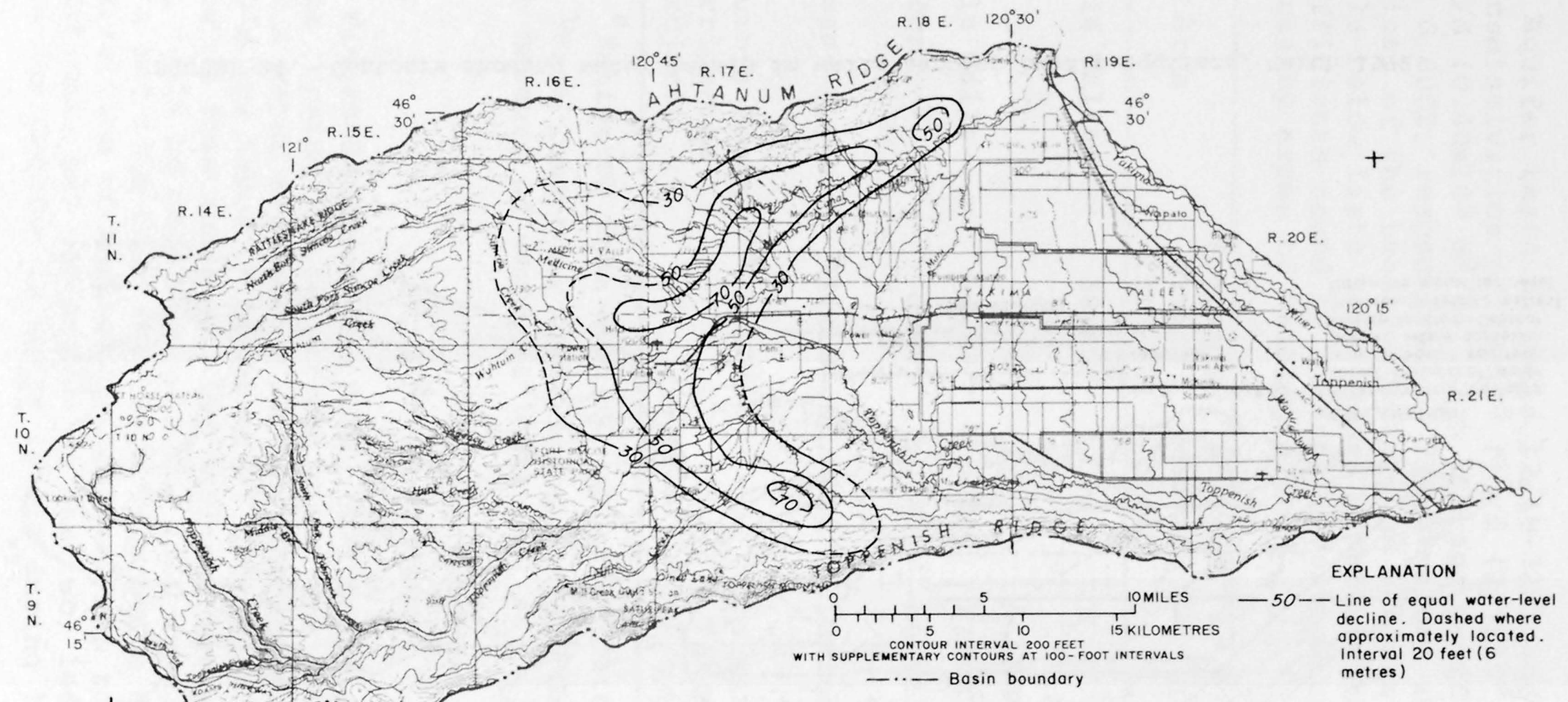

se from U.S. Geologicol Surve

FIGURE 25.--Contours showing water-level declines during 1960-70 in wells tapping the basalt aquifer. 
The water-level decline was relatively uniform from 1956 to 1970, as shown by hydrographs of four wells tapping this aquifer (fig. 26). The rate of pumping steadily increased until 1970, when it stablilized at about 16,000 acre-ft $\left(20\right.$ million $\mathrm{m}^{3}$ ) per year.

Seasonal fluctuations of water levels in wells tapping the basalt aquifer in recent years are shown in figure 27. The figure shows that amplitudes of annual fluctuation average about $20 \mathrm{ft}(6 \mathrm{~m})$. This is due largely to the effects of seasonal pumping, though even in an unstressed situation the water levels would fluctuate slightly to reflect the seasonal nature of recharge entering the aquifer and of natural discharge.

The quantity of water lost from storage in this aquifer may be estimated by applying the storage coefficient to the volume of the cone of depression caused by historic pumpage. The volume of the cone developed between 1960 and 1970 is about $3 \times 10^{11} \mathrm{ft}^{3}\left(8.4 \times 10^{9} \mathrm{~m}^{3}\right)$. Calculated from the larger (more conservative) storage-coefficient value from the pumping test of well 12/18-33Al, approximately $6 \times 10^{7} \mathrm{ft}^{3}\left(17 \times 10^{5} \mathrm{~m}^{3}\right)$ or 1,400 acre-ft ( 1.7 million $\mathrm{m}^{3}$ ) of water was lost from storage. During that same period, about 128,000 acre-ft (158 million $\mathrm{m}^{3}$ ) of water was pumped from wells tapping the aquifer; hence, only about 1 percent of the water pumped represented water lost from storage in the aquifer. The remainder represents that from captured natural discharge from the aquifer and increased recharge due to the increased gradients causing more water to flow from the overlying old valley fill aquifer. 


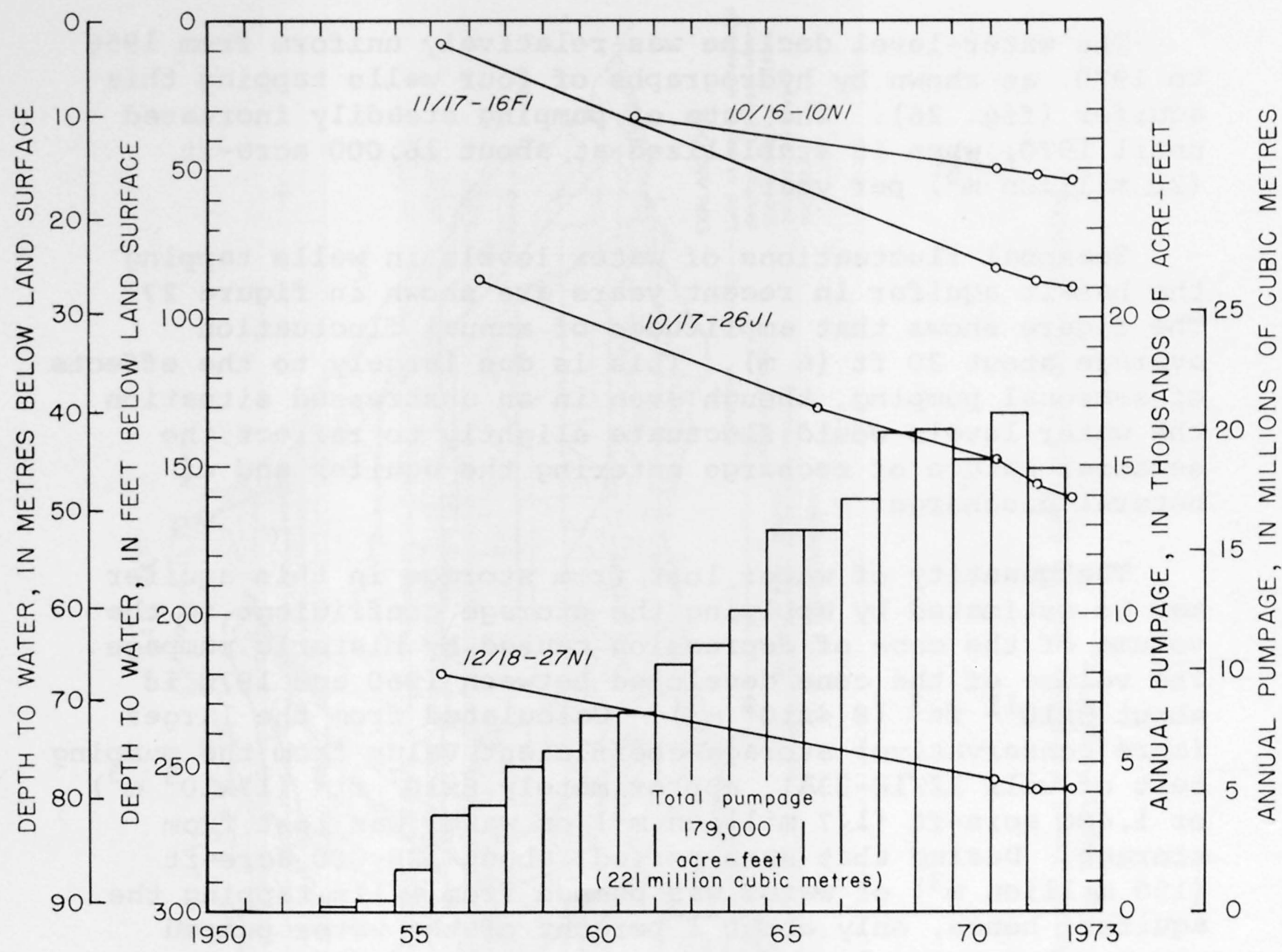

FIGURE 26.--Relationship of spring high-water levels in selected basalt-aquifer wells to annual pumpage, spring 1956 to spring 1973. 


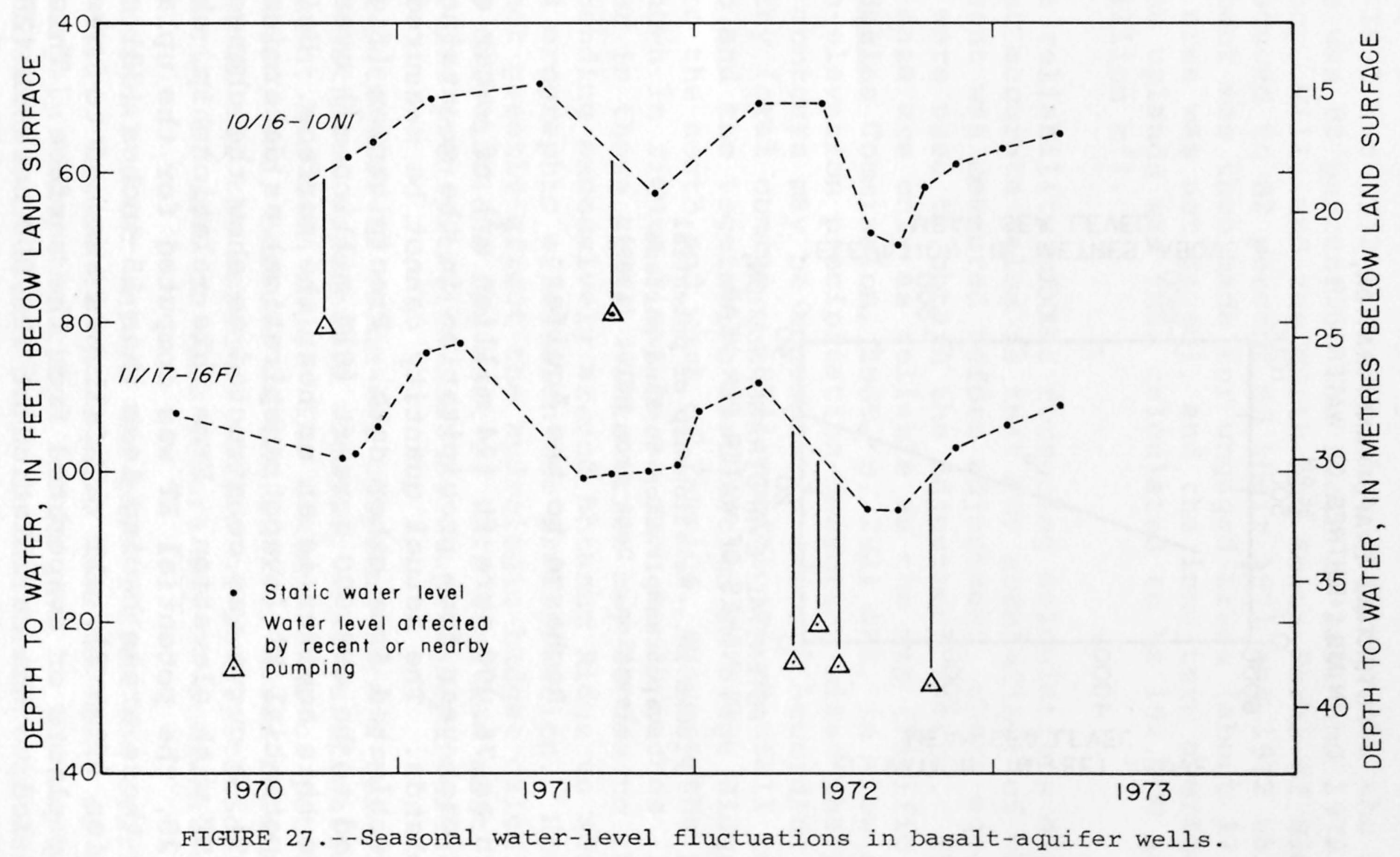




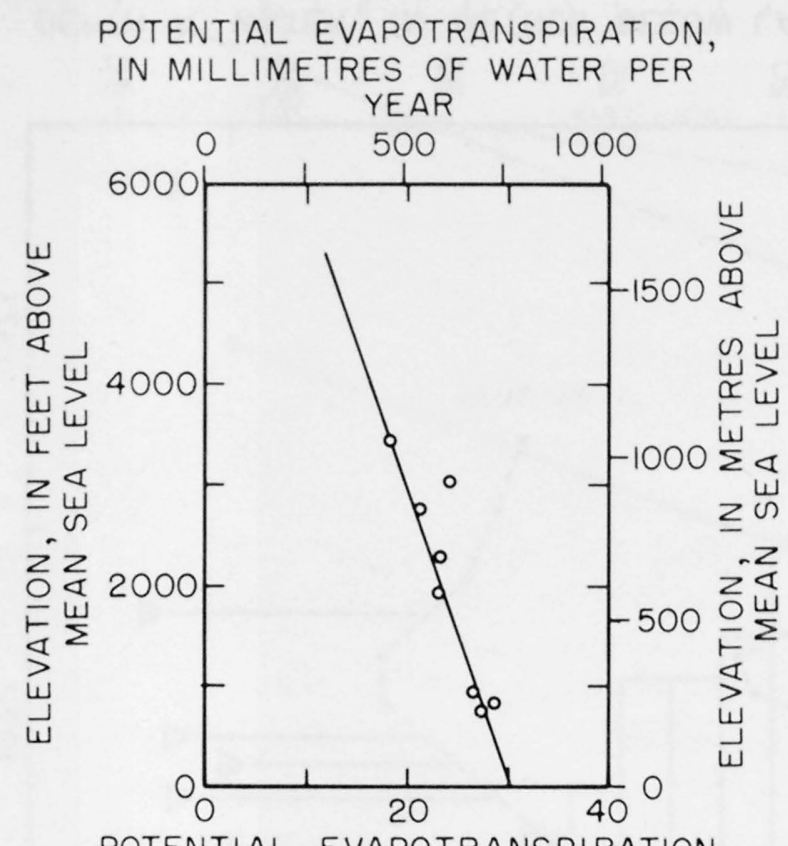

POTENTIAL EVAPOTRANSPIRATION,

IN INCHES OF WATER PER YEAR

FIGURE 28.--Relationship of potential evapotranspiration to land-surface elevation. Data from Hulet (1969).

\section{Recharge to the Aquifer}

As much as 76,000 acre-ft (94 million $\mathrm{m}^{3}$ ) of water enters the basalt each year from precipitation in the mountainous western uplands. The actual quantity cannot be measured but it may be estimated from other data. Precipitation (fig.2) was computed to be 498,000 acre-ft $\left(614\right.$ million $\left.\mathrm{m}^{3}\right)$ over the areas where this aquifer is at or near the surface. Using values of potential ET (evapotranspiration) as determined by Hulet (1969), a curve was constructed to show the change in potential ET with elevation. From this relationship, shown in figure 28, the potential ET was computed for the upland areas. In those areas having less than 15 inches $(381 \mathrm{~mm}$ ) of precipitation (fig. 2), all rainfall was assumed to have been captured by plants or evaporated from the surface. This assumption led to the calculation of 228,000 acre-ft (281 million $\mathrm{m}^{3}$ ) as the excess of precipitation over ET. From streamflow gaging-station records and miscellaneous measurements of ungaged streams in the mountains, the annual discharge from the uplands was calculated to be 152,000 acre-ft (187 million $\mathrm{m}^{3}$ ). This quantity was obtained by comparing the average flow of Toppenish Creek near Fort Simcoe for 1950-70 
to the 1971 and 1972 flows at that station. As the long-term average was 82 percent of the flows in 1971 and 1972, the flows of Agency, Mill, and the North and South Forks of Simcoe Creek were reduced to 82 percent of their 1971 and 1972 values. An adjustment was then made for ungaged areas (about 17 percent of the area was not gaged), and the long-term average discharge from the uplands was thus calculated to be 152,000 acre-ft (187 million $\mathrm{m}^{3}$ ).

The reliability of the foregoing calculations differs. The most accurate value is that for streamflow, of which 83 percent was measured before adjustment, where again measured values were used to obtain the adjustment factor. The precipitation data are only as reliable as the map (Pacific Northwest River Basins Commission, 1969, p. 282) and, in view of the lack of high-elevation precipitation-measuring sites the placement of the contours may be somewhat in error. According to B. L. Foxworthy (oral commun., 1974) unofficial rainfall records at Tampico and the vegetative association on Sedge Ridge, a few miles to the north and west of Tampico, suggest the precipitation shown in figure 2 may be as much as 20 inches $(260 \mathrm{~mm}$ ) in error in these areas. This error may be due to the isohyetal lines bending excessively around Ahtanum Ridge to account for assumed orographic effects on the precipitation. However, it would not greatly affect the hydrologic-budget calculations because calculations for most of this area had most, if not all, of its precipitation lost to evapotranspiration.

The potential-ET value was computed from a formula which has demonstrated reasonable accuracy when verification by measurement has been made. The maximum rate of potential ET was applied, and, because of the limited water-holding capacity of the soil and the seasonal nature of precipitation, the values of potential ET used in this report may be somewhat overestimated.

Additional water enters the basalt from the overlying old valley fill. Figure 22 shows that this movement of water takes place largely along the ridge flanks and in the western part of the lowland area where heads in the basalt aquifer are lower than those in the old valley fill. Table 5 summarizes this recharge by areas of head difference, and shows that the total combined recharge from individual areas of the old valley fill is about 42,000 acre-ft $\left(52\right.$ million $\mathrm{m}^{3}$ ) of water per year. Under natural conditions this recharge is probably smaller, as the declining heads in the basalt aquifer resulting from pumpage, especially in this area, have induced water to move more rapidly into the basalt. 
The configuration of the water-level contours in figure 24 shows that water moves generally eastward in the Toppenish Creek basin. Because the ridge on the east side of Medicine Valley does not impede flow in the deeper zones, about 102,000 acre-ft ( 126 million $\mathrm{m}^{3}$ ) of water per year is moving generally eastward into the lower part of the basin (fig. 24).

\section{Discharge from the Aquifer}

Water leaves the basalt in the Toppenish Creek basin by (1) moving upward into the old valley fill, (2) pumping from wells, and (3) underflow eastward beneath the Yakima River.

In the eastern part of the basin most of the water moves upward into the old valley fill. Figure 22 shows the areas of discharge having positive head difference, and table 5 lists the quantities of water moving in these areas. The total discharge from these areas to the old valley fill is about 94,000 acre-ft (116 million $\mathrm{m}^{3}$ ) per year.

The second most important discharge from the basalt aquifer is through wells, which currently pump about 16,000 acre-ft $\left(20\right.$ million $\left.\mathrm{m}^{3}\right)$ per year from this aquifer.

A smaller amount leaves the Toppenish Creek basin as underflow to the east under the Yakima River, as indicated by the contours in figure 24. The quantity is probably about 8,000 acre-ft ( 9 million $\mathrm{m}^{3}$ ) per year, as estimated from the water budget as the unaccounted outflow.

\section{Present Ground-Water Development}

In 1972 wells tapping the basalt aquifer were distributed in an arc around the western edge of the basin lowland (fig.14). Concentrations of wells along this arc occur in the southwestern part of T.12 N., R.18 E., in the northern half of T.ll N., R.17 E., and in the southeastern part of T.10 N., R.17 E. A small cluster of wells drawing water from both the old valley fill and the upper parts of the basalt is found in the central part of T.10 N., R.16 E. In all, 34 wells obtain all or most of their water from the basalt aquifer, and during the period 1970-72 the annual pumpage averaged about 16,000 acre-ft $\left(20\right.$ million $\mathrm{m}^{3}$ ). 


\section{Potential for Further Development}

Presently the most heavily developed aquifer in the basin, the basalt has had water-level decline in excess of $100 \mathrm{ft}$ $(30 \mathrm{~m})$ in the more heavily pumped areas.

The basalt is highly productive, yielding more than $2,000 \mathrm{gal} / \mathrm{min}(126 \mathrm{l} / \mathrm{s})$ to some wells. However, the distribution of pumpage has not been equal over this aquifer, a factor that undoubtedly has contributed to the large local declines under what would be considered moderate pumpage.

An analysis was performed to project the effects of continued pumping from this aquifer and, thereby, to provide a basis for management decisions regarding the future development of this aquifer.

Because individual basalt wells display unique characteristics representing peculiarities in the aquifer in their immediate vicinity, this analysis was performed on three groups of wells, as shown in figure 14. By dealing with the well groups, a relation between time-drawdown and pumpage was developed to allow projection of declines in the basalt aquifer in response to future pumpage in these areas.

The analytic method used was to determine, for as many time periods as practical, the average rates of drawdown for each period in each group of wells. In some cases, the earliest water level for a well was adjusted to the measurement closest to March by estimating the earlier annual fluctuation from its present annual fluctuation.

For some well groups, where it was possible to calculate average drawdown rates for more than one period prior to 1971, the average drawdown rates of the wells drilled during the first period prior to 1971 was applied to the earlier wells before computing their annual drawdown rates during the earlier period. The resultant values of average drawdown rates over each time period were then divided by the average annual pumping rates for that group over the same time period. This value was then plotted as shown in figure 29, with some scatter (especially in the 1971-73 period for each group) being probably due to short-term variations. However, the points for all groups form a fairly straight line. 


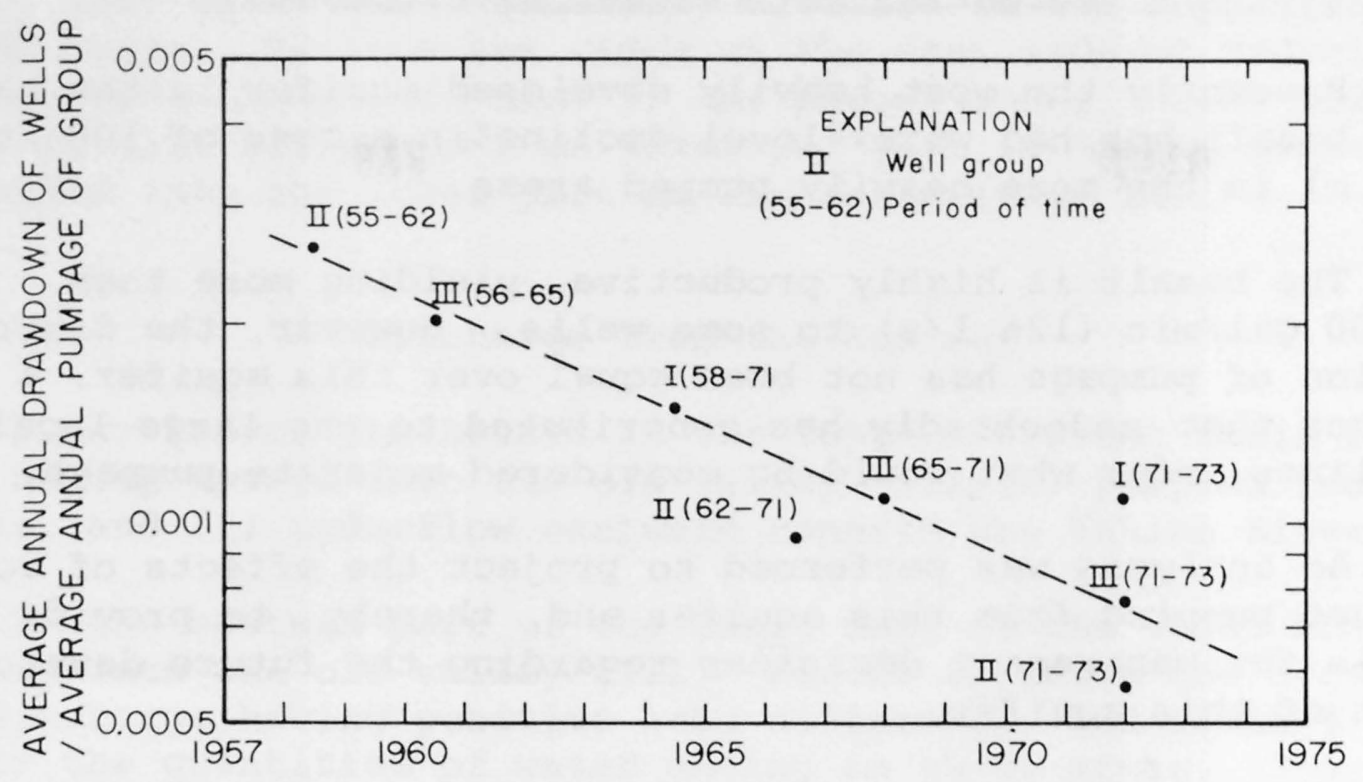

FIGURE 29.--Average annual drawdown per unit pumpage by groups of wells tapping the basalt aquifer in the Toppenish Creek basin.

From this analysis, a nomograph (fig. 30) was prepared that allows the drawdowns to be computed for any year for any chosen value of pumpage. Because the empirical nature of this analysis does not lend itself to accurate projections of extreme values of pumpage, values chosen for projection should be limited to 120 percent of current pumpage in the group, and drawdown projections of more than 5 years should be made with caution.

For the purposes of estimating the costs of pumping water from wells, an analysis of the cost per acre-foot of water was made using an average of the 1974 electrical-power costs of Rural Electrification Administration and Puget Power and Light Co. (These are the major electrical power suppliers to the area.) For the analysis the following assumptions were made:

1. Pumping rate was constant for 6 months.

2. Line pressure was $75 \mathrm{lbs} / \mathrm{in}^{2}\left(5.3 \mathrm{~kg} / \mathrm{cm}^{2}\right)$.

3. Pumping plant efficiency was 53 percent. 


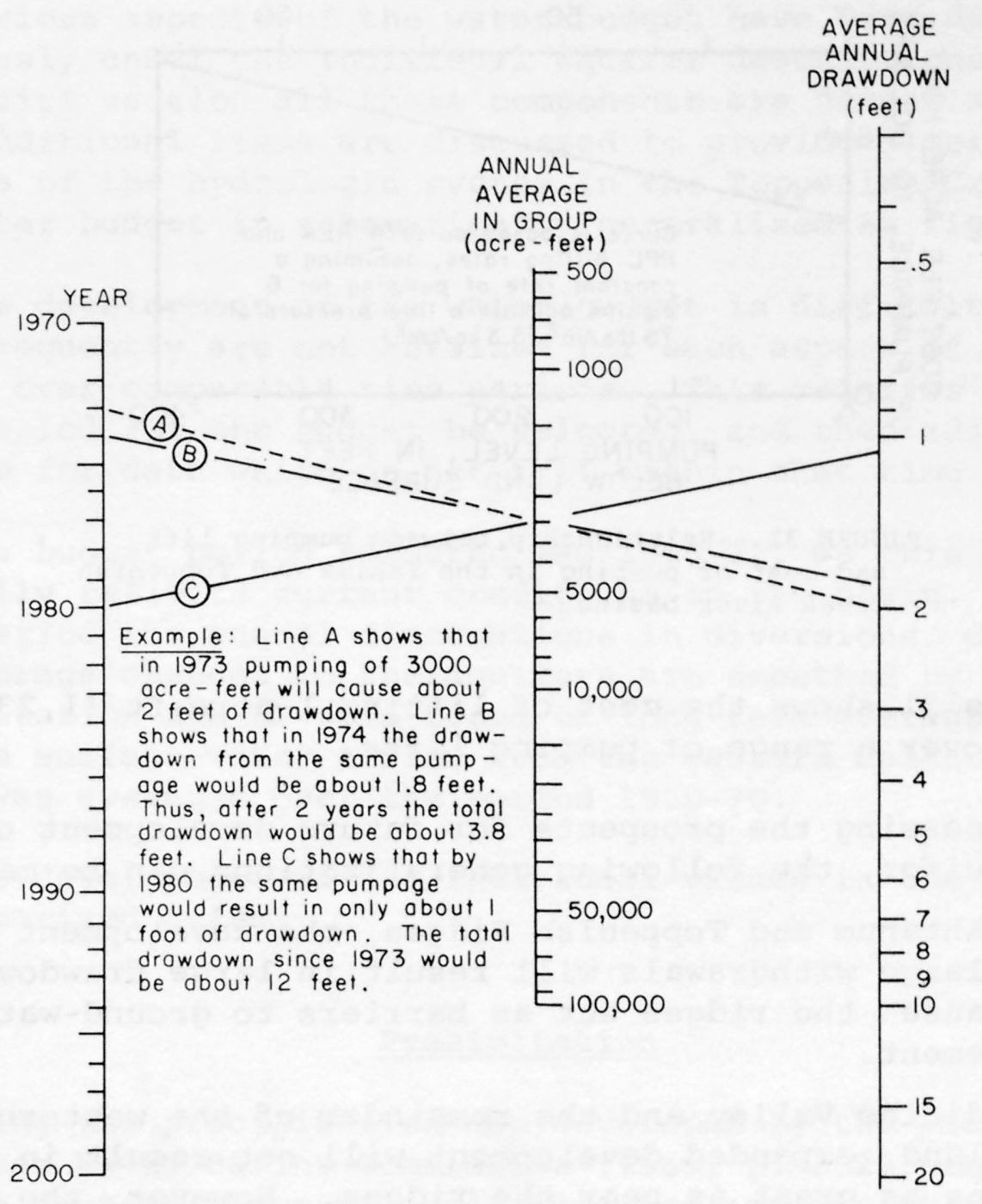

FIGURE 30.--Nomograph for projecting average annual decline of water levels in wells tapping the basalt aquifers. 


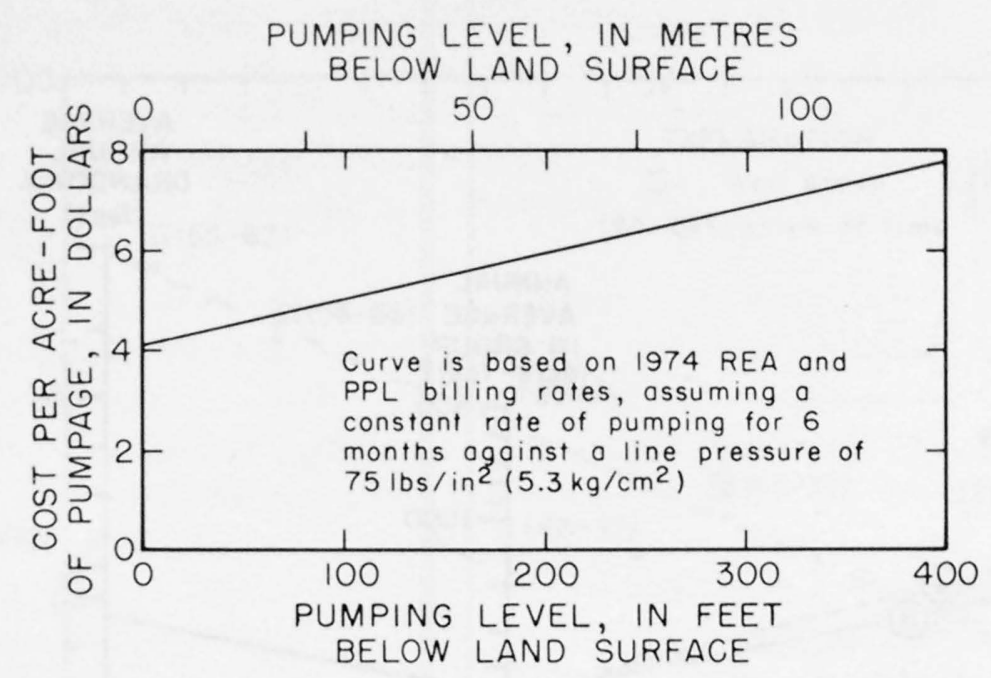

FIGURE 31.--Relationship between pumping lift and cost of pumping in the Yakima and Toppenish Creek River basins.

Figure 31 shows the cost of lifting 1 acre-ft $\left(1,233 \mathrm{~m}^{3}\right)$ of water over a range of pumping lifts.

In assessing the prospects for future development of the basalt aquifer, the following generalizations can be made:

1. Near Ahtanum and Toppenish Ridges, the development of large withdrawals will result in large drawdowns because the ridges act as barriers to ground-water movement.

2. In Medicine Valley and the remainder of the western lowland, expanded development will not result in drawdowns as great as near the ridges. However, the highyield zones in the aquifer are deep, and the water levels in wells tapping these zones are several tens or, at places, hundreds of feet below land surface.

3. In the eastern part of the lowland the basalt aquifer is not presently tapped. Evidence suggests that artesian-pressure heads may be significantly (as much as $150 \mathrm{ft}$ or $46 \mathrm{~m}$ ) above land surface in the southeastern part of the valley. Inasmuch as the basalt surface is generally within 1,000 ft $(305 \mathrm{~m})$ of the land surface, it is within the range of present technology to drill a well in this area that would be invaluable in evaluating this aquifer's potential for producing additional large supplies. 
Various aspects of the water budget have been discussed previously under the individual aquifer descriptions. In this brief section all these components are summarized and some additional items are discussed to provide a more complete picture of the hydrologic system in the Toppenish Creek basin. The water budget is schematically generalized in figure 32 .

The development of the water budget is difficult because data frequently are not obtained for each aspect of the budget over comparable time periods. This requires that a time period for the budget be selected, and then adjustments be made for data which do not fall within that time period.

The budget period selected was $1965-72$, as this period generally reflects current conditions in the basin. Over this period the annual fluctuations in diversions, drains, and storage changes in the aquifers are smoothed by averaging. Precipitation and ET were based on long-term average values, and the surface-water inflow from the western uplands (basalt area) was averaged over the period 1950-70.

The development of the individual values in the budget is summarized below.

\section{Precipitation}

Using the precipitation map developed by the Pacific Northwest River Basins Commission (1969, p. 282), the areas between contour lines were planimetered and the average precipitation in each area was calculated to be as follows:

$$
\begin{aligned}
& \text { Basalt area-......... 498,000 acre-ft } \\
& \text { Old valley fill area--.- 111,000 acre-ft } \\
& \text { Young valley fill area--- 74,000 acre-ft } \\
& \text { Total-..-683,000 acre-ft }
\end{aligned}
$$




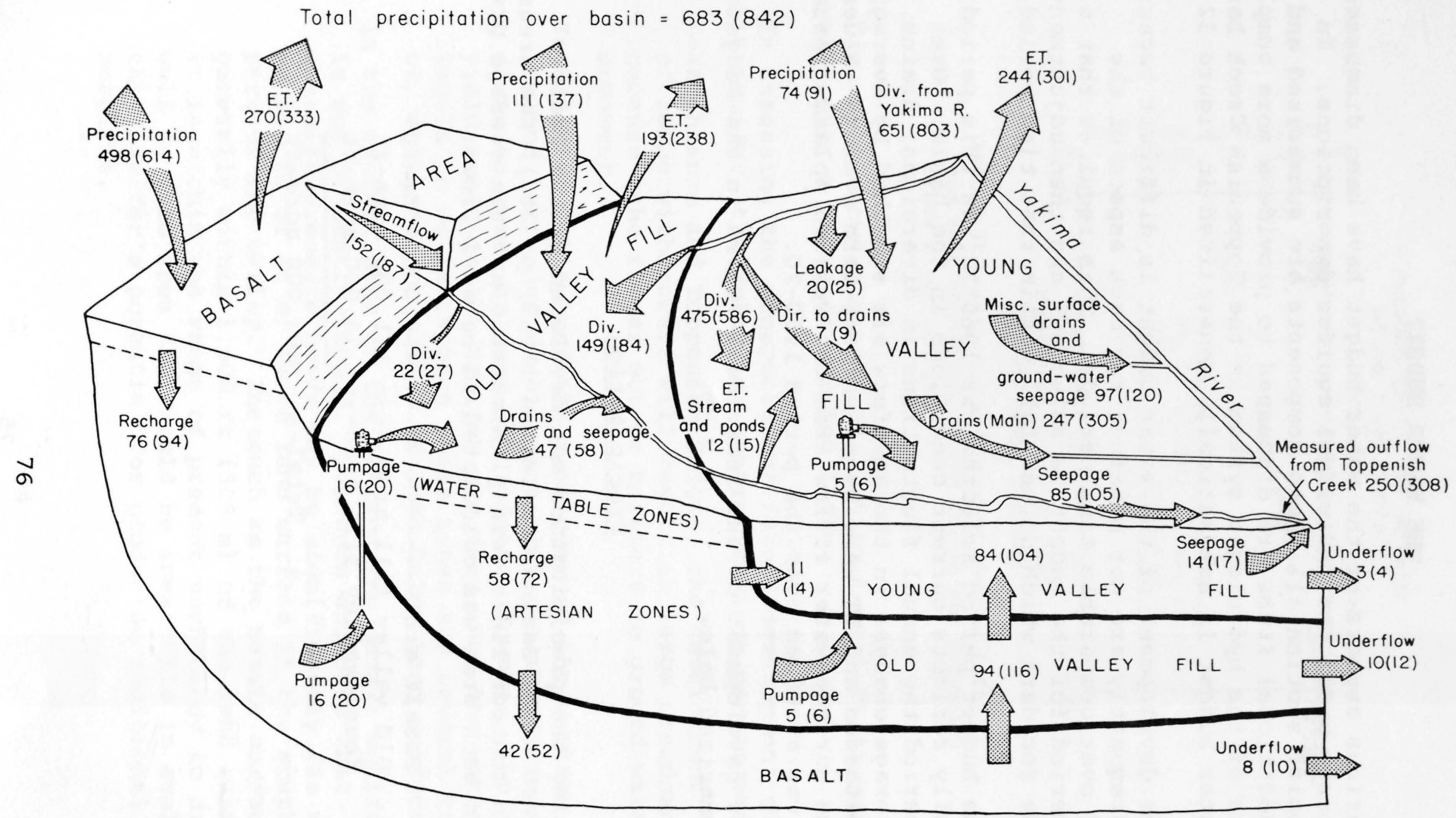

FIGURE 32.--Schematic budget of the hydrologic system in the Toppenish Creek basin. Values are in thousands of acre-feet per year. Values in parentheses are in millions of cubic metres per year. 


\section{Evapotranspiration}

This was computed by the modified Blaney-Criddle formula (U.S. Dept. Agriculture, 1967) for irrigated areas, and for nonirrigated areas the estimate was based on ET figures computed by Hulet (1969).

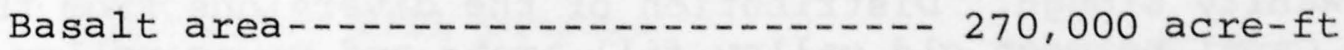
Old valley fill area............ 193,000 acre-ft

(133,000 from irrigated areas)

Young valley fill area-......... 244,000 acre-ft

(222,000 from irrigated areas)

Lakes, ponds, and phreatophyte areas- 12,000 acre-ft

Total--- 719,000 acre-ft

\section{$\underline{\text { Streams }}$}

Flows from the basalt area (uplands) were computed from data for the 1950-70 average flow of Toppenish Creek, the 1971 and 1972 flows of Mill and Agency Creeks, and the flows of North and South Forks of Simcoe Creek as adjusted by comparison with Toppenish Creek for the same years. Ungagedarea contributions (17 percent of total) were computed by the extension of the smaller streams' flows on a per-square-mile basis. Thus, the total streamflow leaving the basalt area (uplands) was calculated to be 152,000 acre-ft (187 million $\mathrm{m}^{3}$ ) per year.

The total surface water leaving the basin in Toppenish Creek during 1965-70, including water diverted to the adjacent Satus Creek basin, averaged 250,000 acre-ft (308 million $\mathrm{m}^{3}$ ) per year. 


\section{$\underline{\text { Diversions }}$}

Based on 1965-72 records of diversion compiled by the BIA, the average annual diversion from the Yakima River into the Toppenish Creek basin during 1965-72 was 651,000 acre-ft ( 812 million $\mathrm{m}^{3}$ ), of which 643,000 acre-ft (792 million $\mathrm{m}^{3}$ ) was via the Main Canal and 8,000 acre-ft ( 10 million $\mathrm{m}^{3}$ ) was via Wanity Slough. Distribution of the diversions from the Main Canal between old valley fill areas and young valley fill areas is based on diversion records provided by the BIA for the year 1971, and is as follows:

$$
\begin{aligned}
& \text { Old valley fill area- } \\
& \text { Young valley fill area---- } 475,000 \text { acre-ft } \\
& \text { [includes } 8,000 \text { acre-ft via Wanity slough] }
\end{aligned}
$$

The remainder of the 651,000 acre-ft (812 million $\mathrm{m}^{3}$ ) diverted from the Yakima River includes 20,000 acre-ft ( 25 million $\mathrm{m}^{3}$ ) lost as seepage to the young valley fill from the Main Canal and 7,000 acre-ft (9 million $\mathrm{m}^{3}$ ) diverted from the Main Canal directly to Harrah Drain.

\section{$\underline{\text { Drains }}$}

This is based on the 1965-72 BIA records of flow from the principal drains from the young valley fill areas. Miscellaneous drains were adjusted from the BIA estimates for 1970 by the proportional differences between the average value and the 1970 values for the main drains.

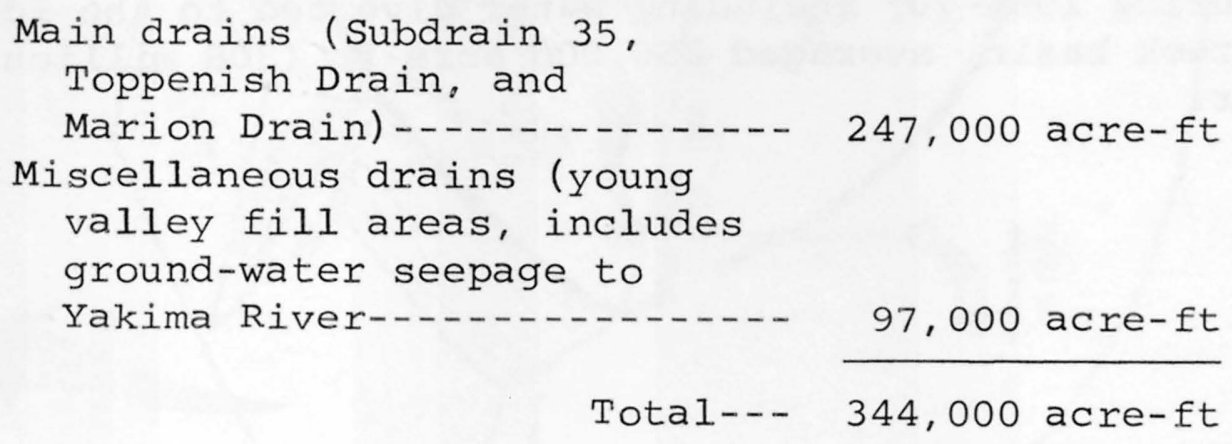




\section{Pumpage}

Values were obtained from records of municipal pumpage and by computing pumpage from individual wells from kilowatthour consumption, using a method described by Luzier and Burt. $(1974$, p. 25,26$)$.

old valley fill pumpage

(in young valley fill areas)-.- 5,000 acre-ft

Basalt pumpage (in old valley-

fill areas)

16,000 acre-ft

Total-- 21,000 acre-ft

\section{Leakage from Main Canal System}

Computed from 1971 records of the diversion to the Main Canal from the Yakima River, less all diversions from the Main Canal, the leakage was about 20,000 acre-ft (25 million $\mathrm{m}^{3}$ ) per year.

\section{Seepage}

Return flow from seepage to the Toppenish Creek channel, computed by balancing the budgets of the old and young valley fill aquifers, was about 85,000 acre-ft (102 million $\mathrm{m}^{3}$ ) per year.

\section{Summary of Water Budget}

A summary of the major components of the water budget follows. The summary omits all those items that involve inter-aquifer or inter-area flows, and only the inflow values-for precipitation and diversion from the Yakima River--and outflow values--for evapotranspiration and underflow from the basin--are included. 
Acre-ft/yr

Inflow:

Precipitation on:

Basalt area (uplands)

498,000

Old valley fill area--.--

111,000

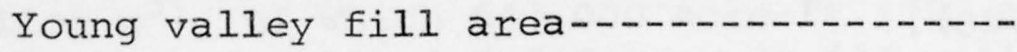

74,000

$\overline{683,000}$

Diversions to:

old valley fill area, from:

Main Canal-....

Local streams-..-...-...-.

149,000

22,000

Young valley fill area, from:

Main Canal and Wanity Slough-..-.--

Main Canal seepage-.-.-.-.-.-.--

Direct diversion to drain-...-..-.-

475,000

20,000

7,000

673,000

Total inflow----

$1,356,000$

Outflow:

Evapotranspiration from:

Basalt area (uplands)

270,000

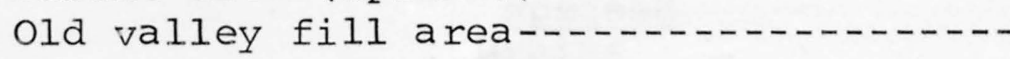

Young valley fill area-.............

Streamflow and ditch drainage from:

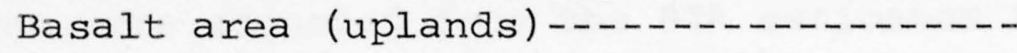

Old valley fill area--.-.-.-.-.-.-.-.

Young valley fill area--.-.-.-.-.-.

Underflow from basin, via:

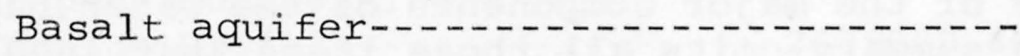

Old valley fill aquifer---.---.---.--

Young valley fill aquifer-...........

193,000

244, 000

707,000

152,000

47,000

429,000

$\mathrm{a} \overline{628,000}$

8,000

10,000

3, 000

21,000

Total outflow--- 1,356,000

${ }^{a}$ Includes 12,000 acre-ft evaparation from lakes, ponds, and streams. 


\section{SUMMARY AND CONCLUSIONS}

The Toppenish Creek basin is underlain by three major aquifers, as follows:

1. Basalt, which underlies the entire basin.

2. Old valley fill, which overlies the basalt in the

lower parts of the basin.

3. Young valley fill, which overlies the old valley

fill in the eastern part of the basin.

All three aquifers are capable of yielding large quantities of water (more than $1,000 \mathrm{gal} / \mathrm{min}$ or $63 \mathrm{l} / \mathrm{s}$ ) to individual wells whose construction is such that the well bore is open to significant thicknesses of saturated aquifer materials.

The basalt and old valley fill have limited potential for increased recharge by management, whereas the young valley fill presents excellent opportunities for management of recharge.

Each of the three aquifers is capable of producing water in sufficient quantity for irrigation or public use. However, the young valley fill is in such close hydraulic connection with the lakes and ponds that agricultural or other cultural practices may cause contamination by persistent chemical compounds and, therefore, this aquifer may not be desirable for public supplies.

Present diversions from the Yakima River and the natural flow of the streams rising in Toppenish Creek basin provide an excess of about 466,000 acre-ft (575 million $\mathrm{m}^{3}$ ) of water that leaves the basin each year. Management of the hydrologic system in the basin could capture some or even most of this excess water. However, capturing most of the excess water and using it for irrigation would accelerate problems of salt buildup in the soils of irrigated acreage. Irrigating all irrigable acreage below the 1,500-ft $\left(457-\mathrm{m}^{3}\right)$ elevation in the basin would require less than 50,000 acre-ft (62 million $\mathrm{m}^{3}$ ) of additional water per year to augment precipitation in the consumptive-use demand of crops on the 32,000 additional acres (130 milition $\mathrm{m}^{2}$ ). Depending on the irrigation method used, a considerably larger quantity of water would be diverted or applied to irrigate the additional acreage; however, the excess over 50,000 acre-ft (62 million $\mathrm{m}^{3}$ ) would remain in the system and would eventually return to the drains. 
Irrigation of additional lands on the south slope of Ahtanum Ridge and the north slope of Toppenish Ridge would most likely be from surface-water sources, as the proximity to ground-water-flow barriers in the ridges, and the remoteness of recharge areas in the basalt aquifer do not create a favorable environment for further development of this aquifer in those two areas.

\section{SELECTED REFERENCES}

Bodhaine, G. L., and Thomas, D. M., 1964, Pacific slope basins in Washington and upper Columbia River basin, pt. 12 of Magnitude and frequency of floods in the United States: U.S. Geol. Survey Water-Supply Paper 1687, $337 \mathrm{p}$.

Environmental Protection Agency, 1972, Water quality criteria 1972: EPA Ecol. Research Series EPA-R3-73-033-March 1973, 594 p.

Flint, R.F., 1938, Origin of the Cheney-Palouse scabland tract, Washington: Geol. Soc. America Bull., v. 49, no. 3, p. 461-523.

Foxworthy, B. L., 1962, Geology and ground-water resources of the Ahtanum Valley, Yakima County, Washington: U.S. Geol. Survey Water-Supply Paper 1598, 100 p.

Hulet, J. C., 1969, Grazing resources inventory, Yakima Indian Reservation, Washington: U.S. Bureau of Indian Affairs Report, $154 \mathrm{p}$.

Johnson, A. L., 1964, Conversion factors and miscellaneous tables: U.S. Geol. Survey open-file report, 19 p.

Kinnison, H. B., and Sceva, J. E., 1963, Effects of hydraulic and geologic factors on streamflow of the Yakima River basin, Washington: U.S. Geol. Survey Water-Supply Paper 1595, $134 \mathrm{p}$.

La Sala, A. M., Jr., and Doty, G. C., 1971, Preliminary evaluation of hydrologic factors related to radioactive water storage in basalt in rocks at the Hanford Reservation, Washington: U.S. Geol. Survey open-file report, $68 \mathrm{p}$.

Longfield, R. J., 1974, Floods of January 1974 in Washington: U.S. Geol. Survey open-file report, 13 p. 
Luzier, J. E., and Burt, R. J., 1974, Hydrology of basalt aquifers and depletion of ground water in east-central Washington: Washington Dept. Ecology Water-Supply Bull. $33,53 \mathrm{p}$.

Mackin, J. H., 1961, A stratigraphic section in the Yakima Basalt and the Ellensburg Formation in south-central Washington: Washington Div. Mines and Geology Rept. Inv. 19, $45 \mathrm{p}$.

Mac Nish, R. D., Randall, A. D., and Ku, H. F. H., 1969, Water availability in urban areas of the Susquehanna River basin: New York Water Resources Comm. Rept. Inv. RI- 7, $23 \mathrm{p}$.

Moore, J. E., and Jenkins, C. T., 1966, An evaluation of the effect of ground water pumpage on the infiltration rate of a semipervious streambed: Water Resources Research, v. 2, no. 4, p. 691-696.

Pacific Northwest River Basins Commission, 1969, Water resources, Appendix V, v.l of Columbia-North Pacific Region comprehensive framework study: Vancouver, Wash., $543 \mathrm{p}$.

Price, C. E., 1961, Artificial recharge through a well tapping basalt aquifers, Walla Walla area, Washington: U.S. Geol. Survey Water-Supply Paper 1594-A, 33 p.

Riggs, H. C., 1968, Some statistical tools in hydrology: U.S. Geol. Survey Water-Resources Inv. Techniques, book 4, ch. Al, 39 p.

---1968, Frequency curves, U.S. Geol. Survey Water-Resources Inv. Techniques, book 4, ch. A2, $15 \mathrm{p}$.

Robbins, S. L., Burt, R. J., and Gregg, D. O., 1975, Gravity and aeromagnetic study of part of the Yakima River basin, Washington: U.S. Geol. Survey Prof. Paper $726-\mathrm{E}$ (in press).

Rosenshein, J. S., Gonthier, J. B., and Allen, W. B., 1968, Hydrologic characteristics and sustained yield of principal ground-water units--Potowomut-Wickford area, Rhode Island: U.S. Geol. Survey Water-Supply Paper 1775, $38 \mathrm{p}$.

Russel1, I. C., 1893, A geological reconnaissance in central Washington: U.S. Geol. Survey Bull. 108, 108 p.

Smith, G. O., 1901, Geology and water resources of a portion of Yakima County, Washington: U.S. Geol. Survey WaterSupply Paper 55, 68 p. 
Smith, G. O., 1903, Description of the Ellensburg quadrangle, Washington: U.S. Geol. Survey Geol. Atlas, Folio 86, 7 p.

Tanaka, H. H., Hansen, A. J., Jr., and Skrivan, J. A., 1974, Digital-model study of ground-water hydrology, Columbia Basin Irrigation Project Area, Washington: Washington Dept. Ecology Water-Supply Bull. 40, 60 p.

[U.S.] Bureau of Indian Affairs, 1973, Irrigation feasibility report, Toppenish-Simcoe Project, Washington [1967 pub. revised]: Portland, Oreg., 102 p.; appendix to report, $77 \mathrm{p}$.

U.S. Department of Agriculture, 1967, Irrigation water requirements: U.S. Soil Conserv. Service Tech. Release 21, 88 p.

U.S. Geological Survey, 1936-65, Surface water records of Washington, 1935-64: Tacoma, Wash., annual reports published for years indicated.

-1966-73, Water resources data for Washington, Part 1, Surface water records, 1965-72: Tacoma, Wash., annual reports published for years indicated.

Van Denburgh, A. S., and Santos, J. F., 1965, Ground water in Washington--its chemical and physical quality: Washington Div. Water Resources Water Supply Bull. 24, $93 \mathrm{p}$.

Walton, W. C., Hills, D. L., and Grundeen, G. M., 1967, Recharge from increased streambed infiltration under varying ground-water-level and stream-stage conditions: Minnesota Univ. [Minneapolis] Water Resources Research Center Bull. 6, 42 p.

Waring, G. A., 1913, Geology and water resources of a portion of south-central Washington: U.S. Geol. Survey WaterSupply Paper 316, 46 p.

Weeks, E. P., Ericson, D. W., and Holt, C. L. R., Jr., 1965, Hydrology of the Little Plover basin, Portage County, Wisconsin, and the effects of water resource development: U.S. Geol. Survey Water-Supply Paper 1811, 78 p. 
A P P E N D I X 
APPENDIX I.--Reduced copies of U.S. Geological Survey 7.5-minute topographic quadrangles, showing areas largely inundated by the flood of January 1974 in the Toppenish Creek basin 


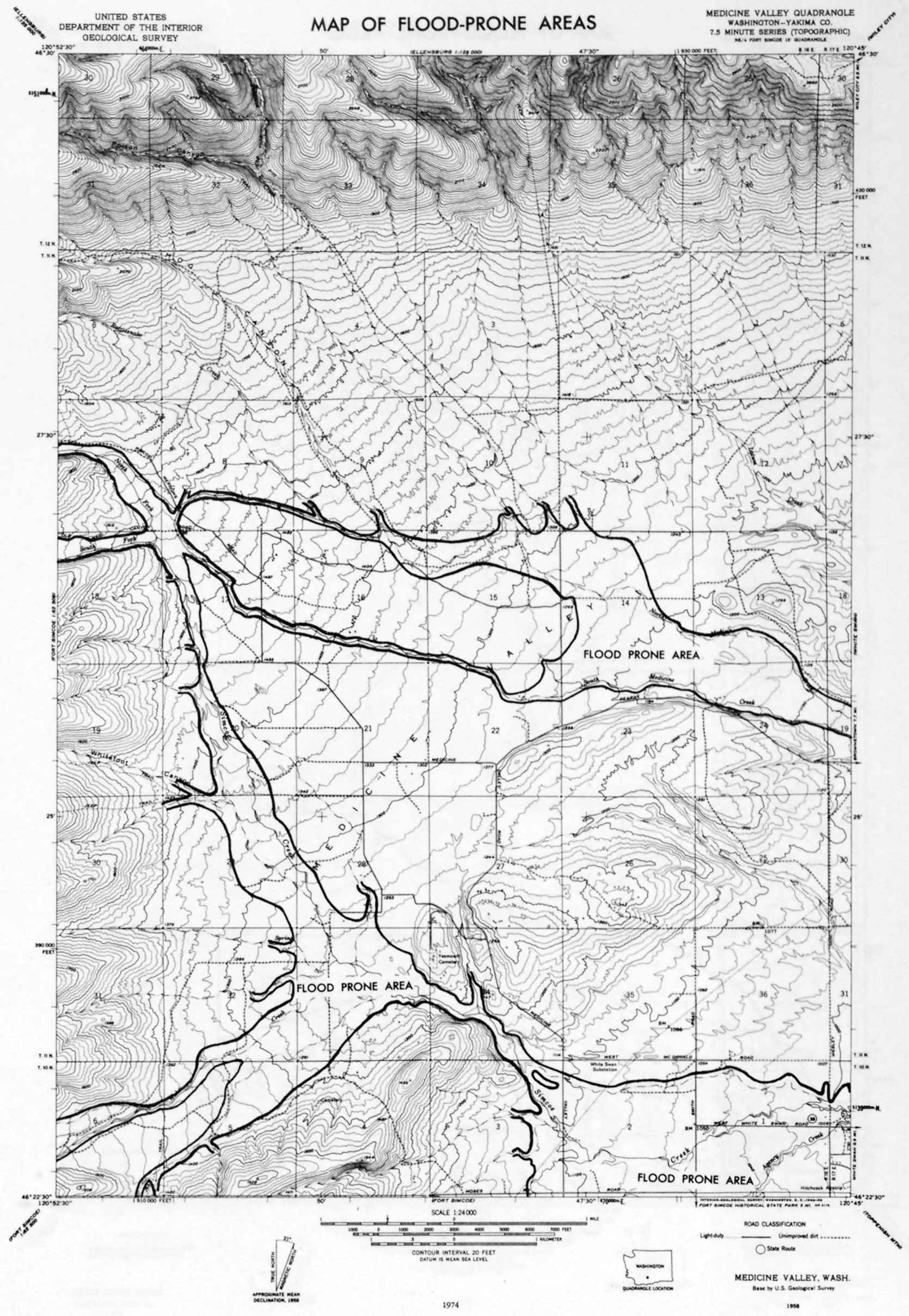




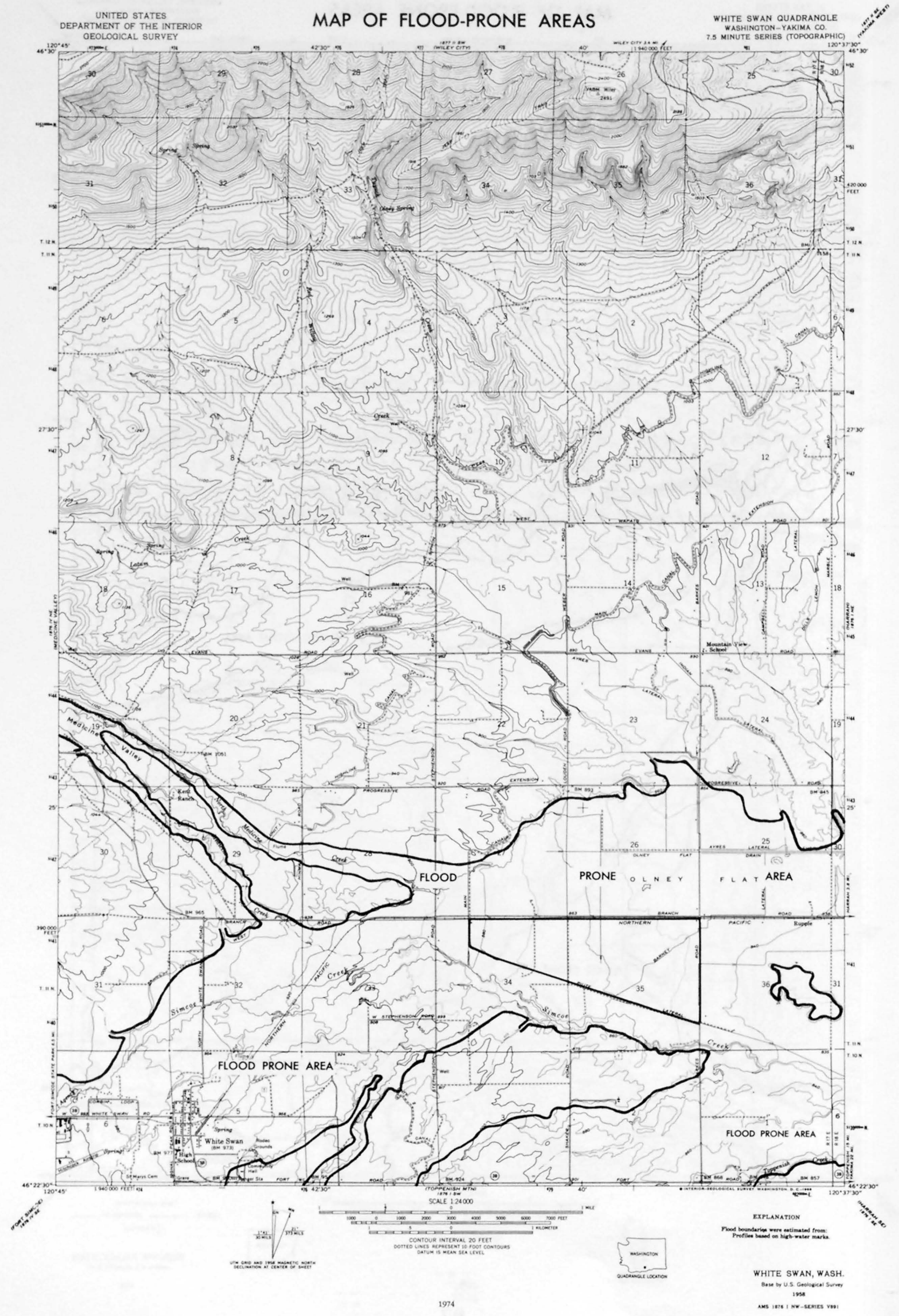




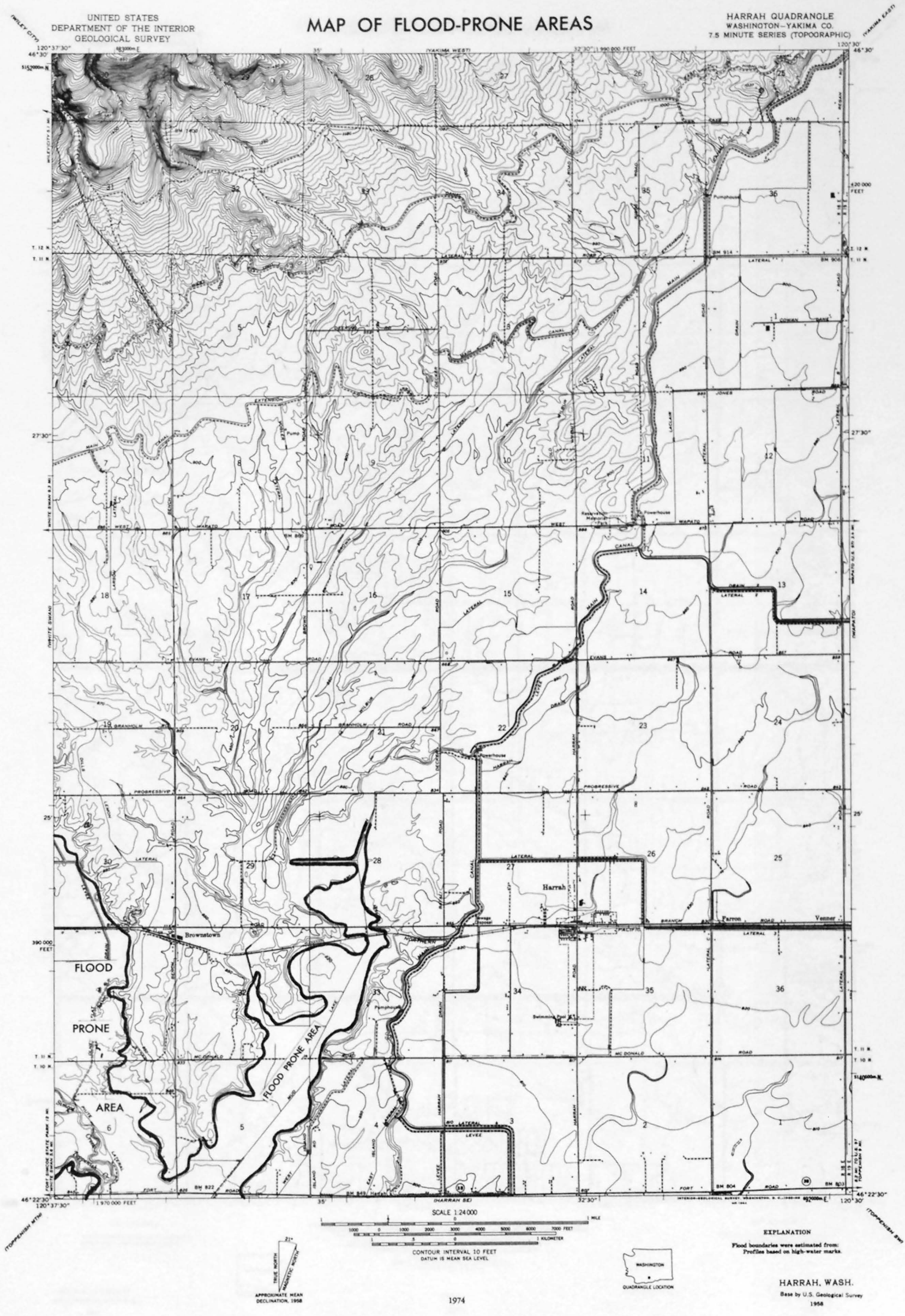




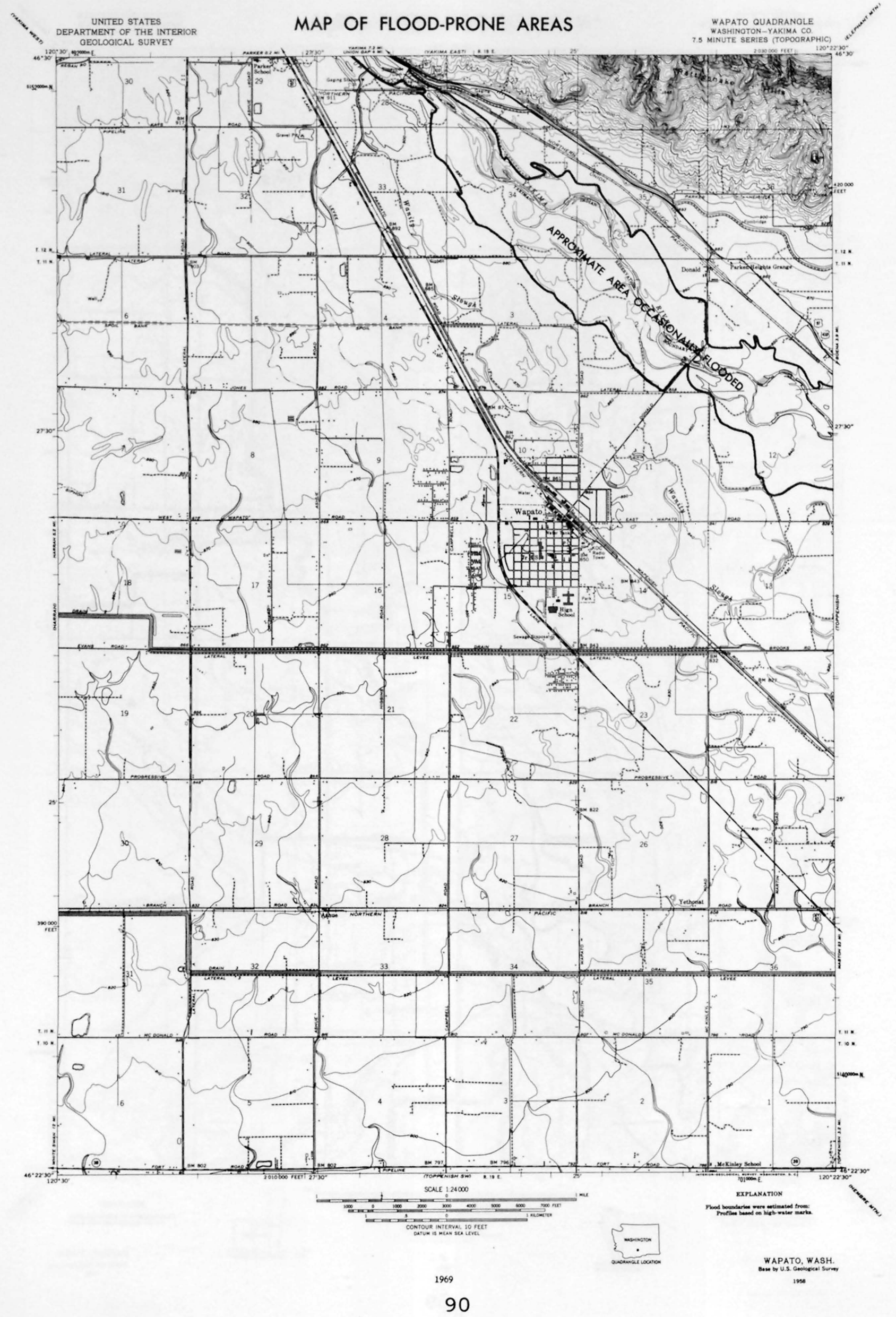




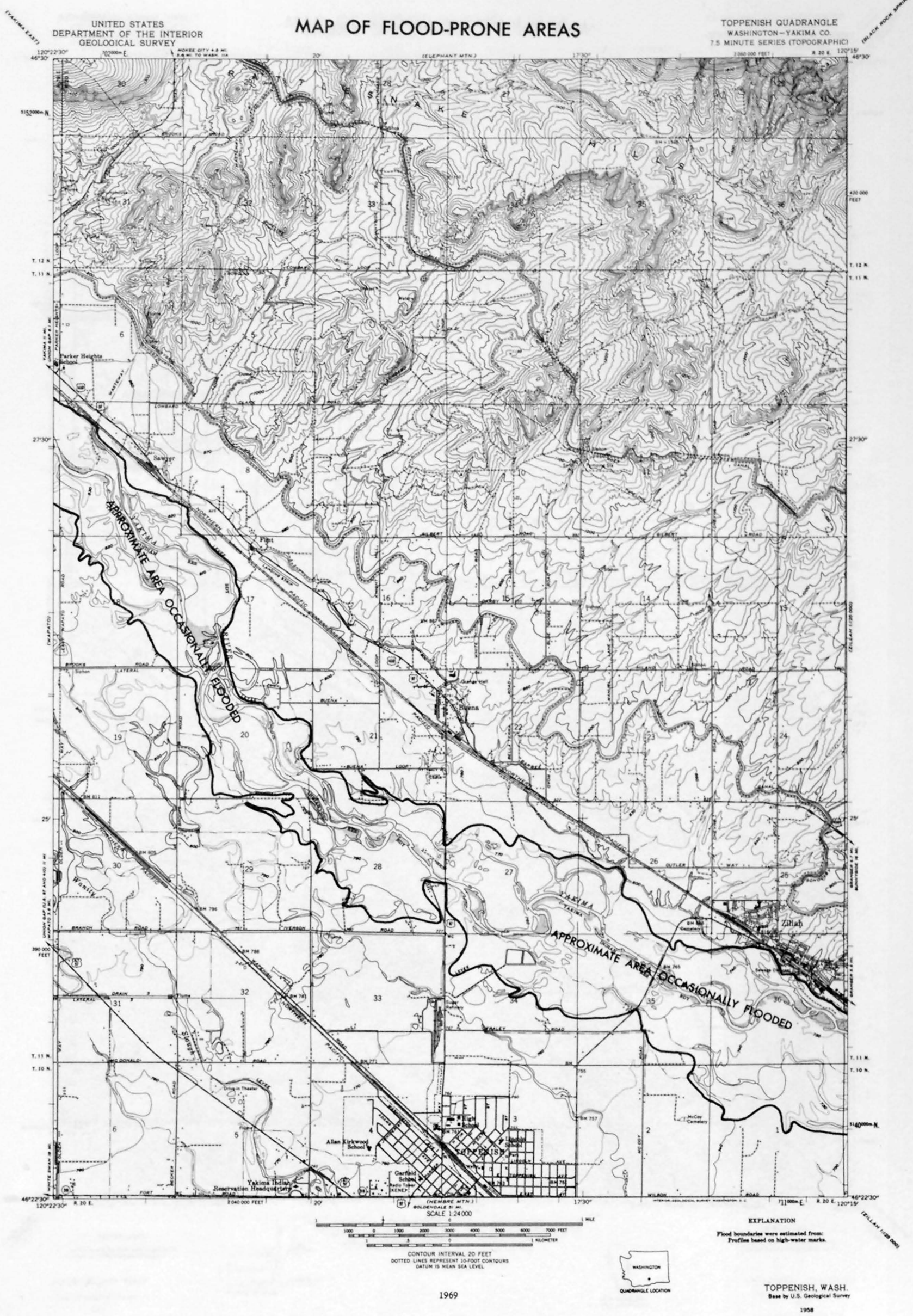




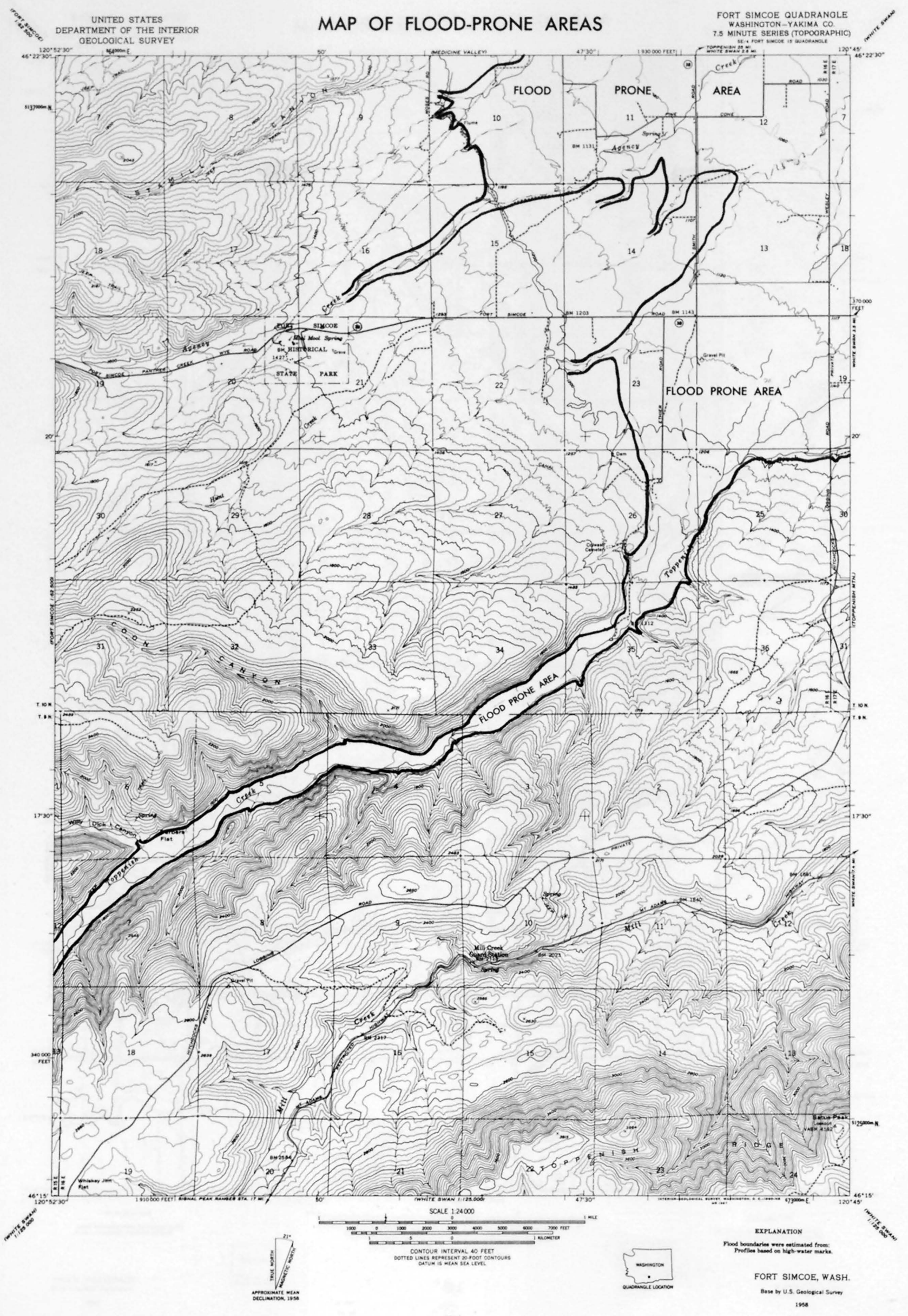




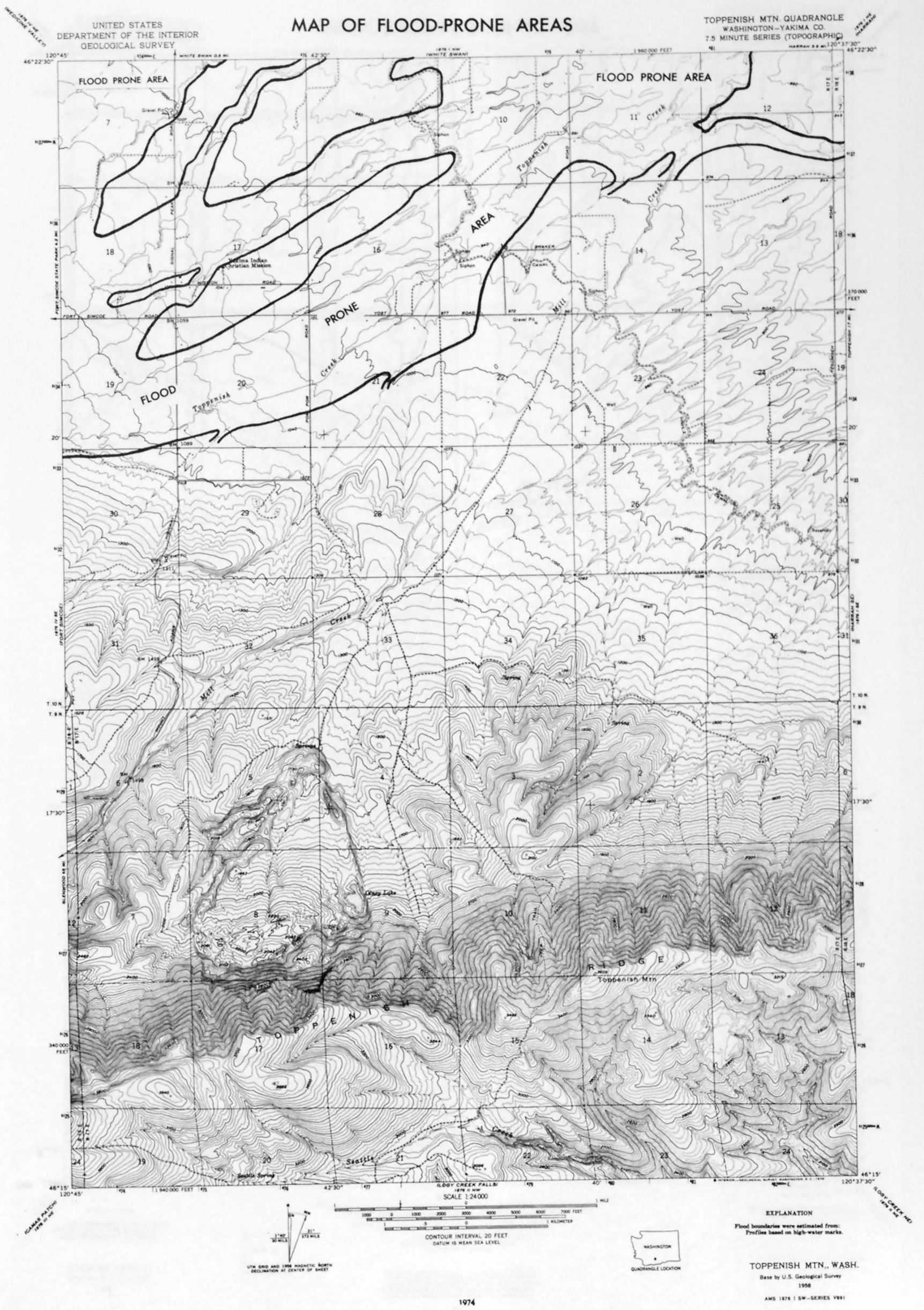




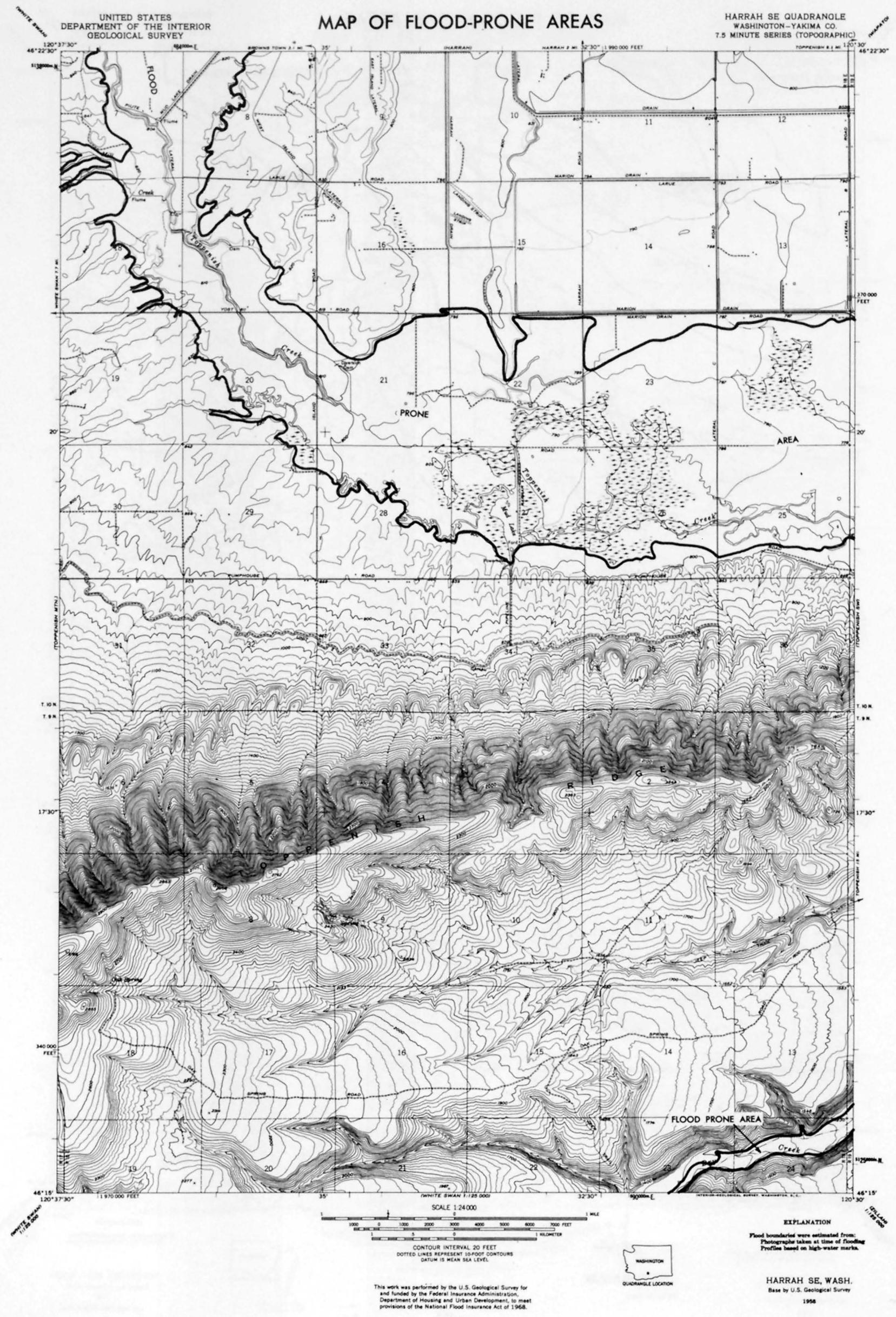




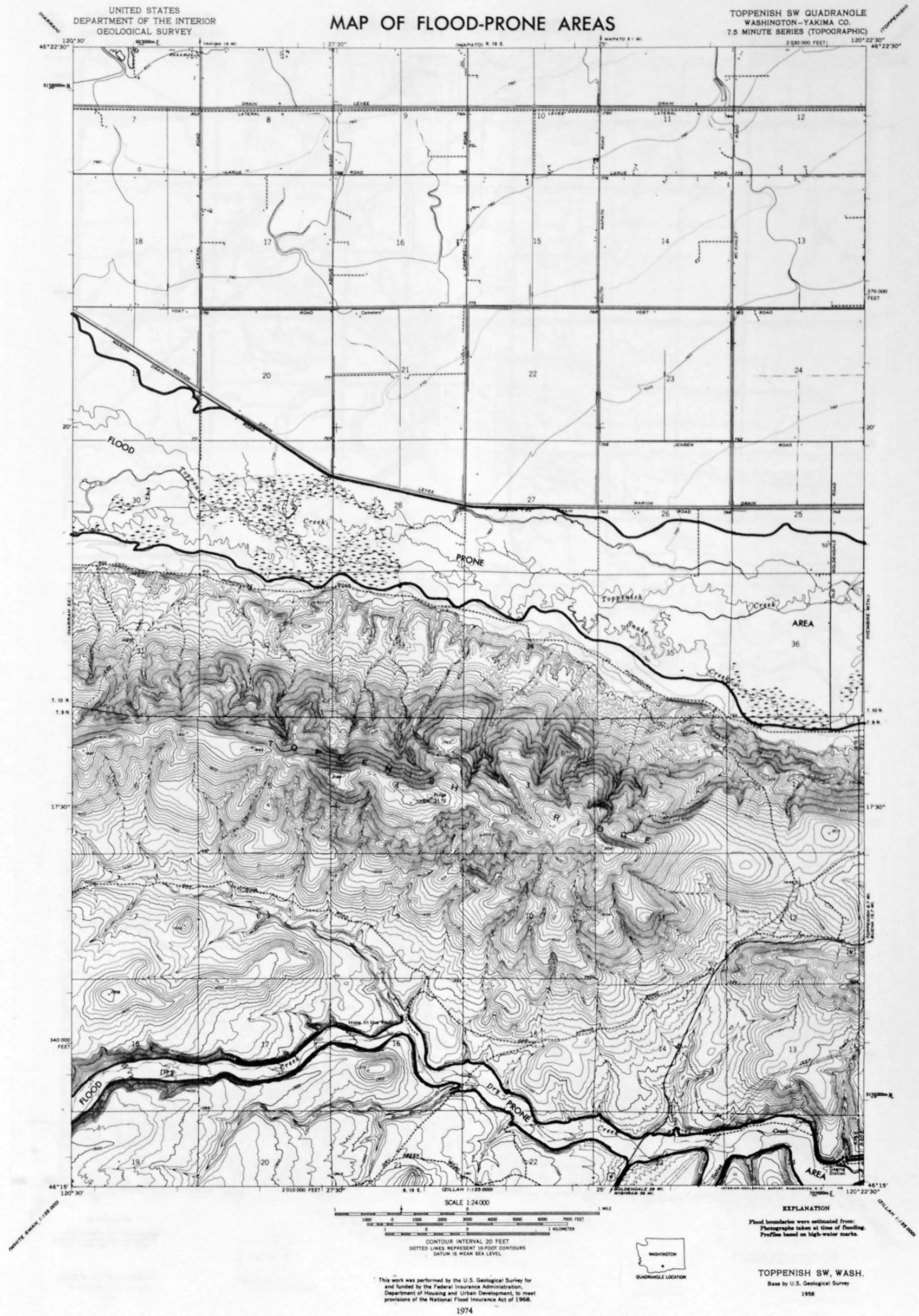




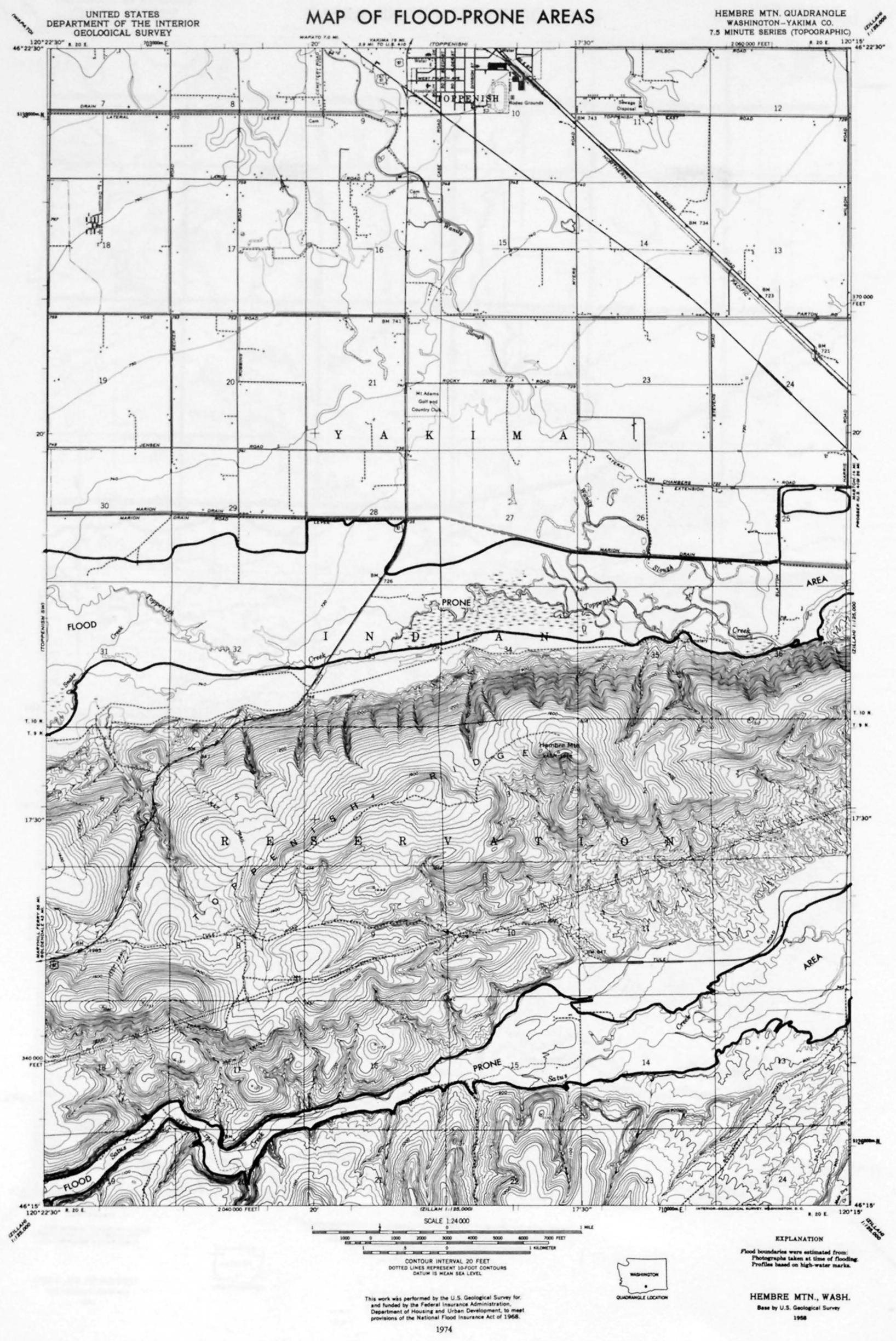


3. UNITED STATES

SE DEPARTMENT OF THE INTERIOR

MAP OF FLOOD-PRONE AREAS

ORANOER QUADRANOLE

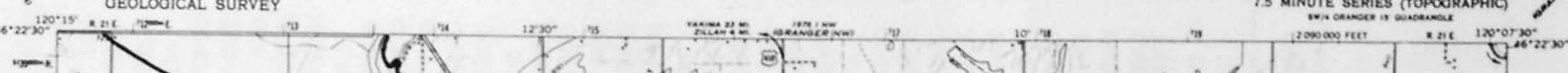

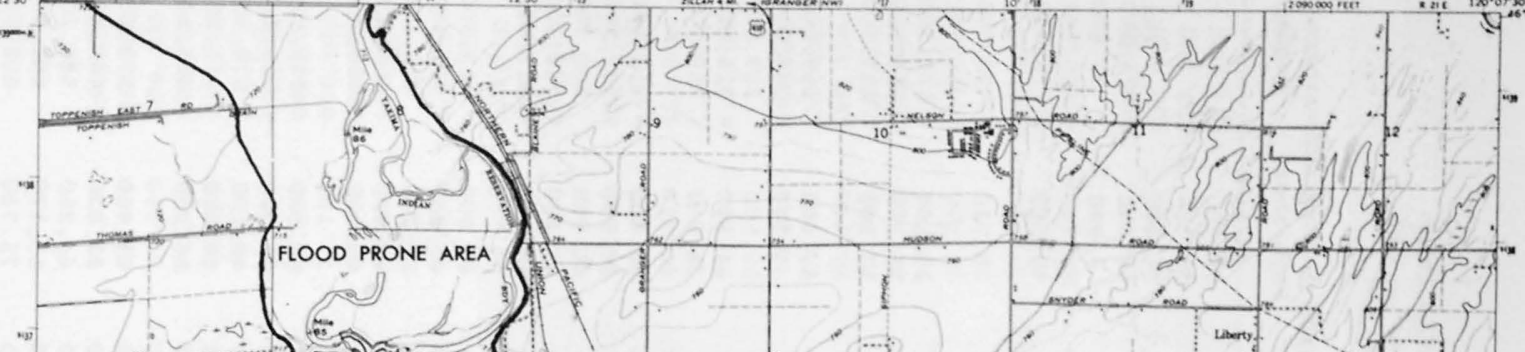

$-9$
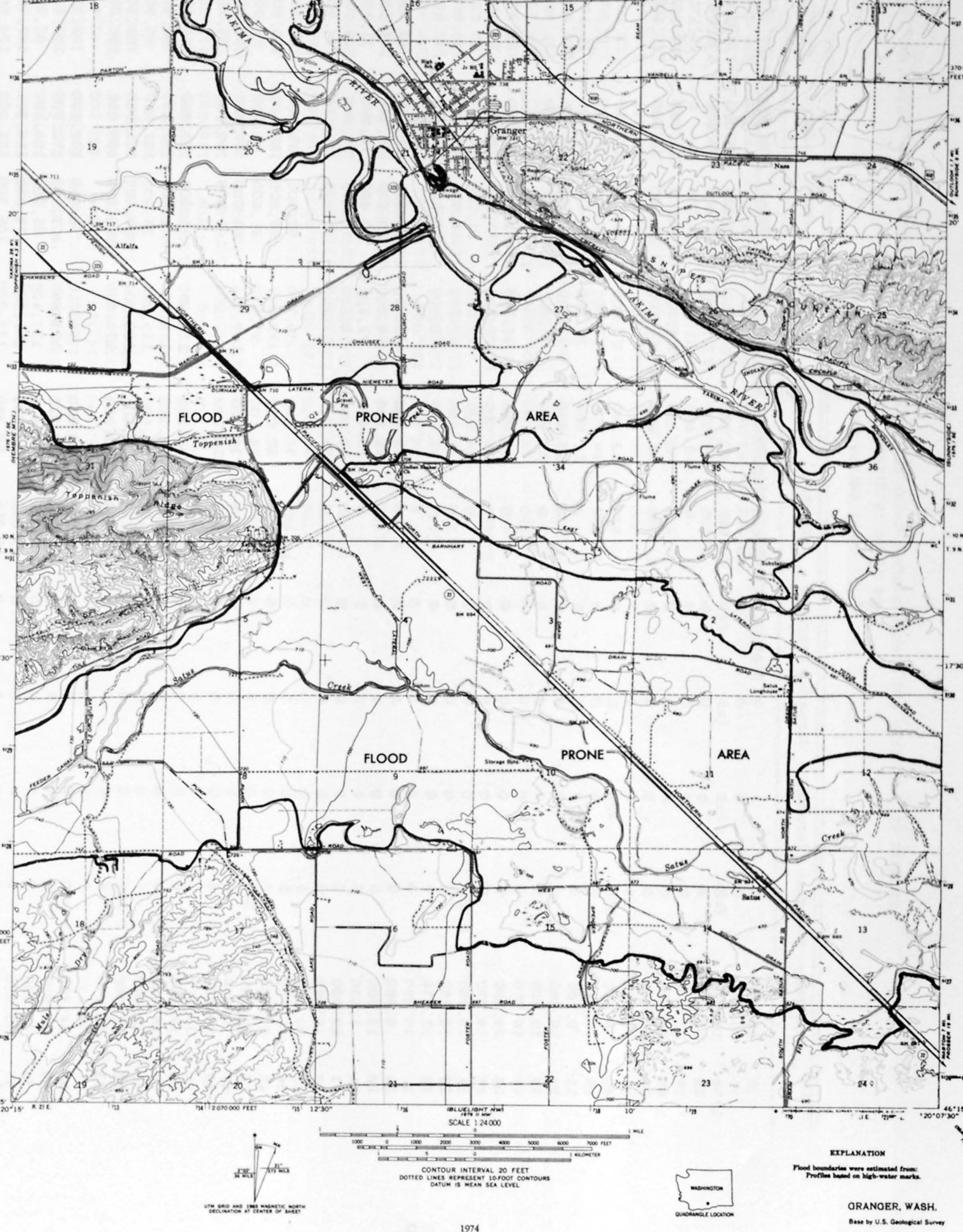
APPENDIX II.--Monthly and annual surface-water discharges at selected sites in the Toppenish Creek basin as shown in figure 4 and listed in table 1

[All values are in acre-feet]

\begin{tabular}{|c|c|c|c|c|c|c|c|c|c|c|c|c|c|}
\hline $\begin{array}{l}\text { Water } \\
\text { Year }\end{array}$ & October & November & December & January & February & March & April & May & June & July & August & September & Annual \\
\hline & & \multicolumn{12}{|c|}{ Station 12503500. Main Canal (New Reservation Canal) near Parker } \\
\hline 1904 & (u) & (u) & (u) & (u) & $(u)$ & (u) & 595 & 1,660 & 2,920 & 5,310 & 4,110 & 4,380 & (u) \\
\hline 05 & 1,490 & 0 & 0 & 0 & 0 & 0 & 0 & 0 & 5,810 & 8,420 & 7,990 & 0 & 23,710 \\
\hline 06 & 0 & 0 & 0 & 0 & 0 & 0 & 2,450 & 11,800 & 10,300 & 0 & 4,170 & 4,940 & 33,660 \\
\hline 07 & 5,440 & 0 & 0 & 0 & 0 & 0 & 0 & 14,400 & 16,100 & 15,700 & 14,100 & 0 & 65,740 \\
\hline 08 & 0 & 0 & 0 & 0 & 0 & 0 & 7,870 & 18,200 & 15,200 & 16,000 & 12,400 & 9,040 & 78,710 \\
\hline 09 & 6,460 & 1,550 & 1,480 & 0 & 0 & 0 & 12,200 & 17,500 & 14,300 & 17,700 & 11,400 & 8,330 & 90,920 \\
\hline 10 & 9,780 & 0 & 0 & 0 & 0 & 0 & 14,900 & 21,300 & 17,600 & 17,000 & 7,870 & 6,130 & 94,580 \\
\hline 11 & 9,780 & 0 & 0 & 0 & 0 & 0 & 17,900 & 22,500 & 23,400 & 21,700 & 15,100 & 10,100 & 120,500 \\
\hline 12 & 9,390 & 0 & 0 & 0 & 0 & 0 & 23,800 & 33,100 & 26,100 & 26,400 & 14,400 & 15,100 & 148,300 \\
\hline 13 & 10,900 & 0 & 0 & 0 & 0 & 0 & 10,800 & 33,800 & 26,900 & 30,600 & 21,400 & 17,100 & 151,500 \\
\hline 14 & 9,780 & 0 & 0 & 0 & 0 & 0 & 25,000 & 35,200 & 31,700 & 30,200 & 26,700 & 10,900 & 169,500 \\
\hline 15 & 4,330 & 0 & 0 & 0 & 0 & 0 & 16,000 & 36,600 & 32,200 & 28,800 & 19,400 & 7,130 & 144,500 \\
\hline 16 & 10,400 & 4,570 & 0 & 0 & 0 & 0 & 20,600 & 43,000 & 37,200 & 31,000 & 33,200 & 19,600 & 199,600 \\
\hline 17 & 7,250 & 0 & 0 & 0 & 0 & 0 & 11,400 & 43,900 & 44,500 & 45,300 & 40,900 & 21,500 & 214,800 \\
\hline 18 & 5,830 & 0 & 0 & 0 & 0 & 0 & 14,600 & 49,400 & 55,900 & 50,000 & 42,600 & 31,800 & 250,100 \\
\hline 19 & 6,660 & 0 & 0 & 0 & 0 & 0 & 23,700 & 67,300 & 59,200 & 57,400 & 60,700 & 36,000 & 311,000 \\
\hline 20 & 13,500 & 0 & 0 & 0 & 0 & 0 & 15,700 & 69,200 & 59,600 & 65,900 & 59,500 & 39,100 & 322,500 \\
\hline 21 & 5,630 & 0 & 0 & 0 & 0 & 0 & 28,400 & 72,600 & 69,400 & 71,900 & 71,900 & 40,900 & 360,700 \\
\hline 22 & 10,900 & 0 & 0 & 0 & 0 & 0 & 11,600 & 76,200 & 79,100 & 79,900 & 69,500 & 41,100 & 368,300 \\
\hline 23 & 6,390 & 0 & 0 & 0 & 0 & 0 & 33,800 & 93,200 & 79,900 & 75,100 & 74,000 & 55,200 & 417,000 \\
\hline 24 & 0 & 0 & 0 & 0 & 0 & 16,300 & 77,400 & 89,100 & 82,900 & 81,800 & 74,300 & 44,000 & 465,800 \\
\hline 25 & 23,400 & 0 & 0 & 0 & 0 & 21,900 & 57,000 & 99,600 & 86,500 & 92,000 & 83,700 & 47,300 & 511,400 \\
\hline 26 & 14,700 & 1,340 & 0 & 0 & 0 & 12,200 & 74,100 & 97,500 & 83,600 & 91,000 & 69,000 & 27,700 & 471,100 \\
\hline 27 & $\begin{array}{l}14,700 \\
0\end{array}$ & $\begin{array}{r}1,040 \\
0\end{array}$ & 0 & 0 & 0 & 3,830 & 39,600 & 104,000 & 83,600 & 97,300 & 88,600 & 49,700 & 466,600 \\
\hline 28 & 9,100 & 0 & 0 & 0 & 0 & 1,540 & 25,400 & 102,000 & 102,000 & 90,900 & 89,700 & 45,600 & 466,200 \\
\hline 29 & 27,200 & 0 & 0 & 0 & 0 & 0 & 52,800 & 115,000 & 95,000 & 97,800 & 94,300 & 60,500 & 542,600 \\
\hline 30 & 24,400 & 11,700 & 0 & 0 & 0 & 6,020 & 83,100 & 112,000 & 96,000 & 98,100 & 85,900 & 47,000 & 564,200 \\
\hline 31 & 19,000 & 0 & 0 & 0 & 1,600 & 35,400 & 85,600 & 115,000 & 84,900 & 102,000 & 88,900 & 46,100 & 578,500 \\
\hline 32 & 27,400 & 7,290 & 0 & 0 & 0 & 7,110 & 63,600 & 118,000 & 97,400 & 103,000 & 93,300 & 54,200 & 571,300 \\
\hline 33 & 31,100 & 0 & 0 & 0 & 0 & 4,400 & 59,800 & 122,000 & 106,000 & 109,000 & 105,000 & 66,900 & 604,200 \\
\hline 34 & 24,900 & 0 & 0 & 0 & 0 & 17,060 & 84,600 & 96,710 & 96,960 & 101,600 & 92,710 & 63,460 & 578,000 \\
\hline 35 & 16,600 & 0 & 0 & 0 & 0 & 10,670 & 95,210 & 124,900 & 103,100 & 111,700 & 103,400 & 81,030 & 646,600 \\
\hline 36 & 26,020 & 0 & 0 & 0 & 0 & 7,070 & 71,430 & 122,400 & 95,960 & 106,100 & 95,940 & 64,250 & 589,200 \\
\hline 37 & 45,670 & 0 & 0 & 0 & 0 & 3,880 & 49,730 & 131,000 & 79,880 & 119,300 & 107,300 & 65,170 & 601,900 \\
\hline 38 & 20,850 & 0 & 0 & 0 & 0 & 6,010 & 58,990 & 123,800 & 105,300 & 111,000 & 104,600 & 71,730 & 602,300 \\
\hline
\end{tabular}




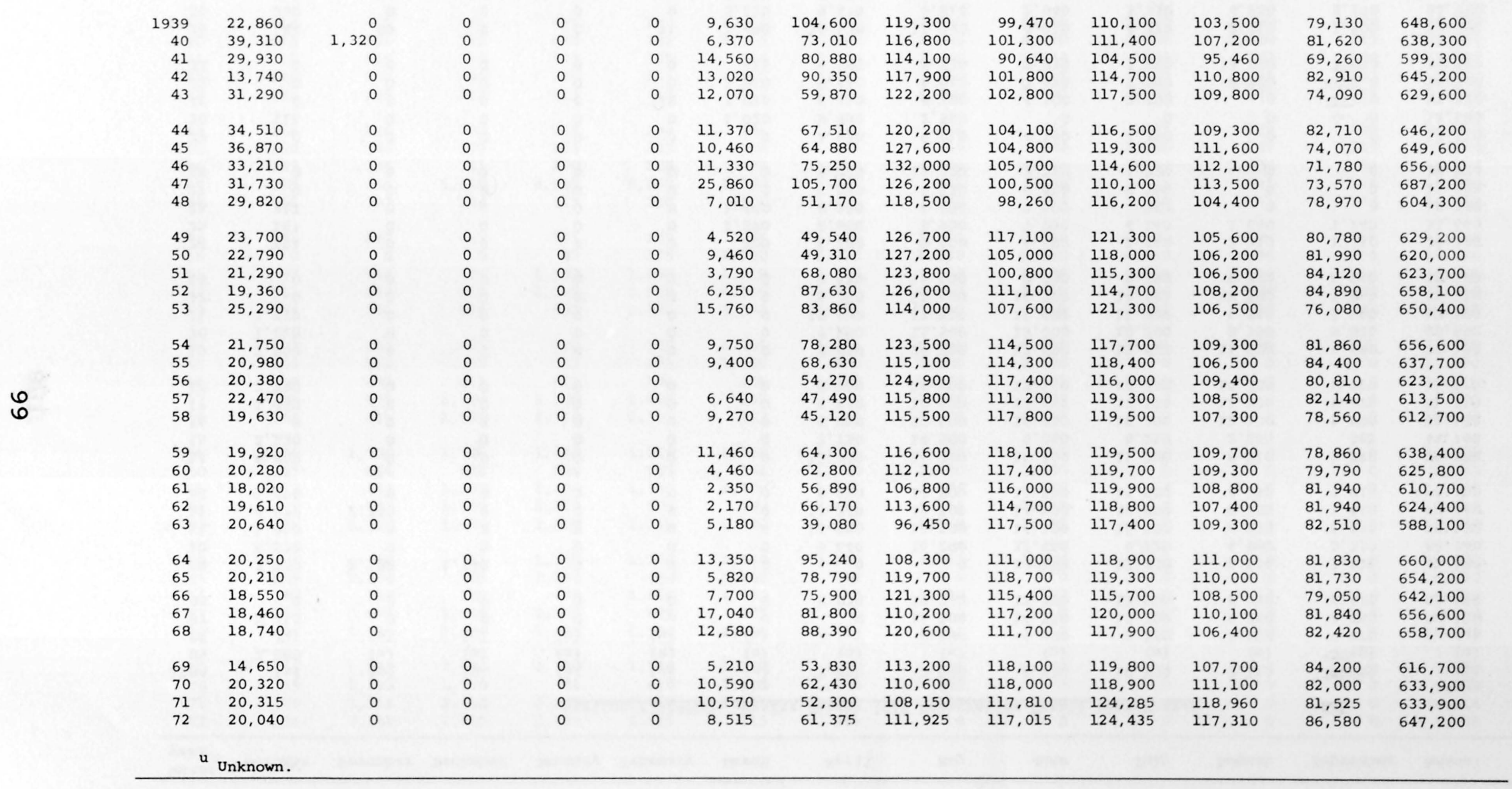


APPENDIX II.--Monthly and annual surface-water discharges at selected sites in the Toppenish Creek basin as shown in figure 4 and listed in table 1--Continued

\begin{tabular}{|c|c|c|c|c|c|c|c|c|c|c|c|c|c|}
\hline $\begin{array}{l}\text { Water } \\
\text { year }\end{array}$ & October & November & December & January & February & March & April & May & June & Juiy & August & September & Annual \\
\hline & & & & $\underline{\text { Stati }}$ & n 125040 & Wani & Slough & d Reserv & on Canal & ear Park & & & \\
\hline 1904 & (u) & (u) & (u) & (u) & (u) & (u) & 2,980 & 7,990 & 8,630 & 10,100 & 9,160 & 5,950 & (u) \\
\hline 05 & 2,680 & (u) & (u) & (u) & (u) & (a) & (u) & (a) & (u) & (u) & (u) & (u) & (u) \\
\hline 06 & (u) & (u) & (u) & (u) & (u) & (u) & (u) & 9,780 & 6,600 & 8,180 & 2,800 & 3,470 & (u) \\
\hline 07 & 2,210 & 0 & 0 & 0 & u & 0 & 0 & 16,200 & 14,700 & 13,300 & 6,460 & 3,240 & 56,100 \\
\hline 08 & 0 & 0 & 0 & 0 & 0 & 0 & 8,030 & 15,700 & 12,300 & 12,500 & 8,730 & 6,430 & 63,690 \\
\hline 09 & 3,720 & 2,500 & 1,740 & 0 & 0 & 0 & 0 & 0 & 13,100 & 12,900 & 6,520 & 3,620 & 44,100 \\
\hline 10 & 5,570 & 0 & 0 & 0 & 0 & 0 & 9,640 & 15,200 & 12,600 & 9,220 & 4,980 & 3,730 & 60,940 \\
\hline 11 & 5,960 & 0 & 0 & 0 & 0 & 0 & 13,800 & 17,500 & 14,100 & 11,300 & 6,520 & 5,950 & 75,130 \\
\hline 12 & 4,970 & 2,340 & 0 & 0 & 0 & 0 & 13,200 & 15,700 & 14,600 & 10,900 & 8,180 & 7,440 & 77,330 \\
\hline 13 & 5,470 & 0 & 0 & 0 & 0 & 0 & 6,950 & 17,800 & 14,500 & 16,500 & 8,360 & 7,910 & 77,490 \\
\hline 14 & 6,460 & 0 & 0 & 0 & 0 & 0 & 12,900 & 16,300 & 15,300 & 11,200 & 8,210 & 5,320 & 75,690 \\
\hline 15 & 2,230 & 0 & 0 & 0 & 0 & 0 & 7,730 & 14,500 & 9,060 & 8,250 & 2,660 & 305 & 44,740 \\
\hline 16 & 0 & 0 & 0 & 0 & 0 & 0 & 9,250 & 17,500 & 16,400 & 10,200 & 12,200 & 5,080 & 70,630 \\
\hline 17 & 1,920 & 0 & 0 & 0 & 0 & 0 & 6,830 & 18,600 & 17,700 & 17,100 & 12,000 & 7,220 & 81,370 \\
\hline 18 & 2,200 & 0 & 0 & 0 & 0 & 0 & 8,000 & 16,400 & 17,200 & 10,700 & 10,300 & 6,720 & 71,520 \\
\hline 19 & 2,700 & 0 & 0 & 0 & 0 & 0 & 8,690 & 20,200 & 17,000 & 12,400 & 11,500 & 5,690 & 78,180 \\
\hline 20 & 1,010 & 0 & 0 & 0 & 0 & 0 & 9,160 & 15,500 & 13,000 & 10,200 & 8,790 & 5,930 & 63,590 \\
\hline 21 & 1,730 & 0 & 0 & 0 & 0 & 0 & 10,900 & 13,700 & 15,600 & 11,900 & 9,350 & 5,500 & 68,680 \\
\hline 22 & 0 & 0 & 0 & 0 & 0 & 0 & 5,350 & 17,600 & 16,200 & 14,400 & 11,700 & 7,860 & 73,110 \\
\hline 23 & 0 & 0 & 0 & 0 & 0 & 0 & 8,520 & 15,500 & 8,000 & 9,980 & 9,320 & 6,960 & 58,280 \\
\hline 24 & 151 & 0 & 0 & 0 & 0 & 208 & 5,290 & 9,400 & 4,600 & 2,460 & 2,310 & 1,350 & 25,770 \\
\hline 25 & 167 & 0 & 0 & 0 & 0 & 1,870 & 6,660 & 9,900 & 7,980 & 4,160 & 1,680 & 1,240 & 33,660 \\
\hline 26 & 311 & 0 & 0 & 0 & 0 & 1,400 & 6,330 & 6,880 & 3,500 & 363 & 0 & 0 & 18,780 \\
\hline 27 & 0 & 0 & 0 & 0 & 0 & 0 & 5,540 & 9,230 & 6,880 & 5,390 & 0 & 0 & 27,040 \\
\hline 28 & 0 & 0 & 0 & 0 & 0 & 0 & 8,020 & 12,300 & 7,220 & 1,280 & 0 & 0 & 28,820 \\
\hline 29 & 0 & 0 & 0 & 0 & 0 & 0 & 4,620 & 9,010 & 4,140 & 4,350 & 0 & 0 & 22,120 \\
\hline 30 & 111 & 0 & 0 & 0 & 0 & 1,020 & 8,490 & 2,560 & 0 & 0 & 0 & 0 & 12,180 \\
\hline 31 & 0 & 0 & 0 & 0 & 728 & 3,920 & 6,610 & 8,780 & 4,100 & 3,380 & 0 & 0 & 27,520 \\
\hline 32 & 0 & 0 & 0 & 0 & 0 & 1,910 & 5,450 & 8,960 & 7,470 & 7,790 & 4,800 & 0 & 36,380 \\
\hline 33 & 0 & 0 & 0 & 0 & 0 & 415 & 6,590 & 8,330 & 2,870 & 3,270 & 4,060 & 1,050 & 26,580 \\
\hline 34 & 184 & 89 & 0 & 0 & 71 & 1,490 & 10,620 & 11,940 & 4,670 & 4,320 & 3,310 & 1,500 & 38,190 \\
\hline 35 & 200 & 0 & 0 & 0 & 0 & 3,210 & 9,470 & 5,810 & 2,940 & 3,730 & 4,220 & 3,170 & 32,750 \\
\hline 36 & 325 & 0 & 0 & 0 & 0 & 1,400 & 8,690 & 10,640 & 3,110 & 1,490 & 922 & 244 & 26,820 \\
\hline 37 & 160 & 0 & 0 & 0 & 81 & 1,950 & 3,320 & 9,090 & 3,330 & 5,570 & 4,480 & 1,220 & 29,200 \\
\hline 38 & 431 & 653 & 417 & 246 & 160 & 269 & 2,310 & 9,410 & 4,140 & 5,090 & 3,090 & 1,480 & 27,700 \\
\hline
\end{tabular}




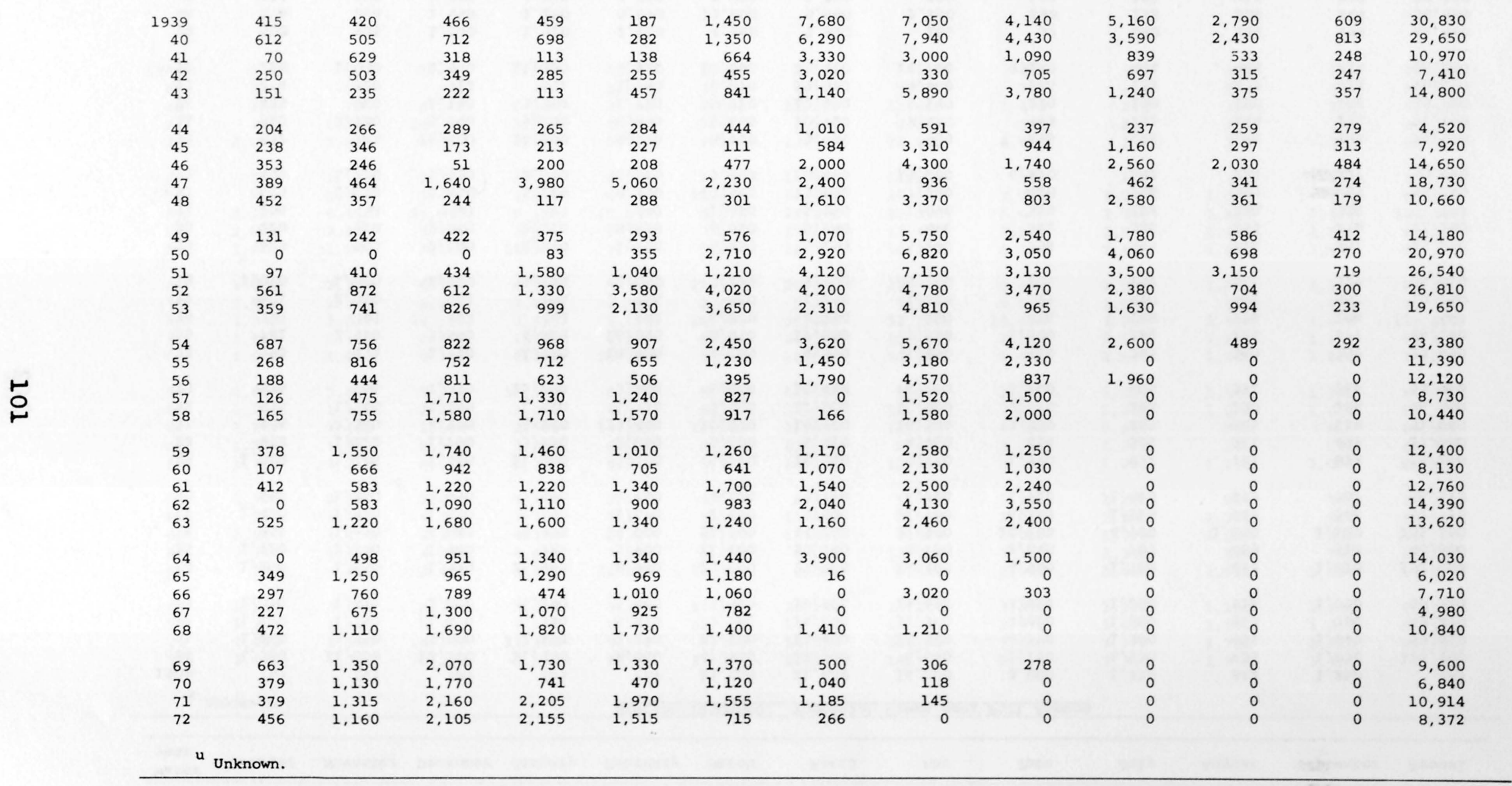


APPENDIX II.--Monthly and annual surface-water discharges at selected sites in the Toppenish Creek basin as shown in figure 4 and listed in table 1--Continued

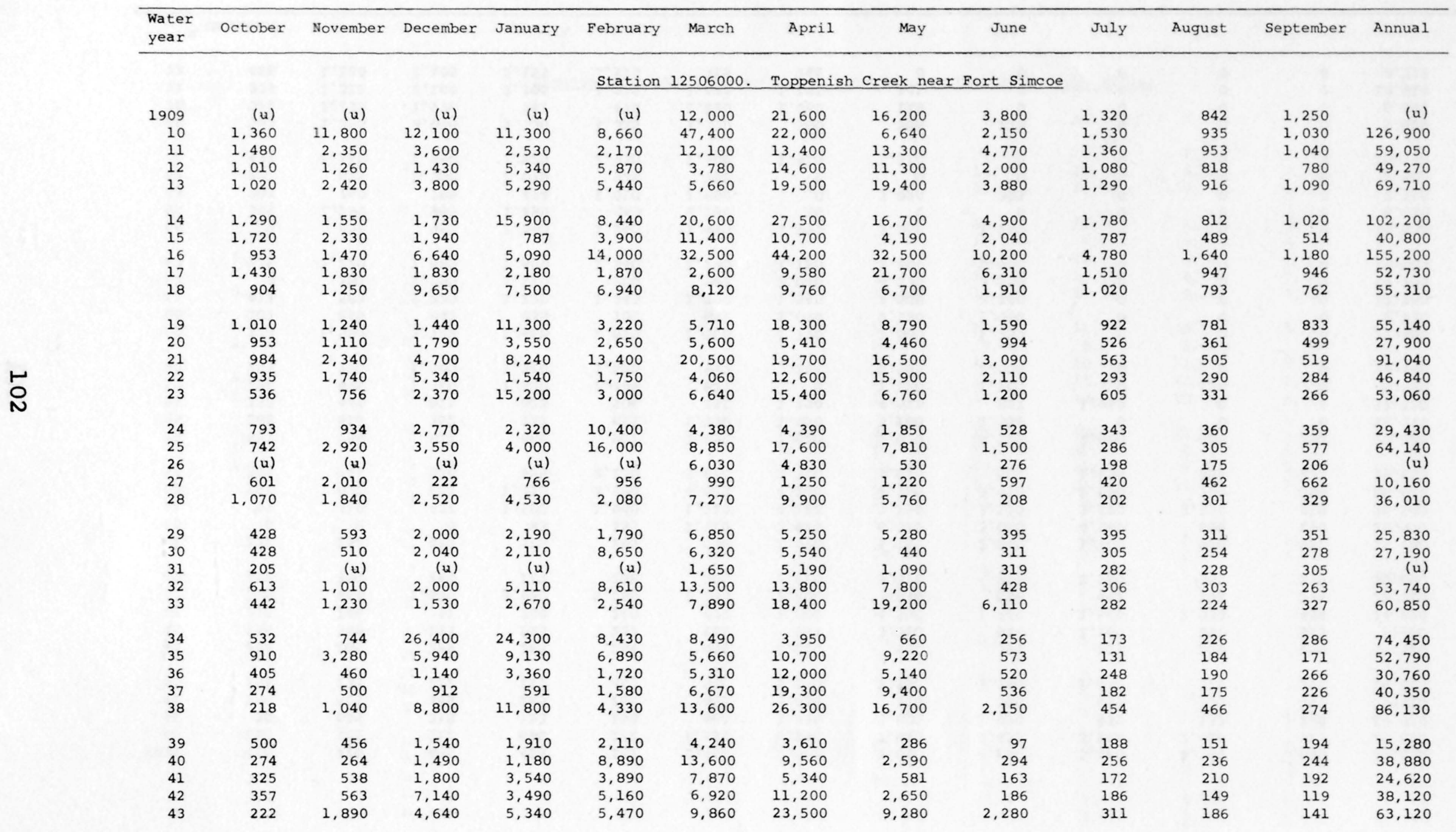




\begin{tabular}{|c|c|c|c|c|c|c|c|c|c|c|c|c|c|}
\hline 1944 & 722 & 980 & 1,170 & 1,030 & 1,080 & 3,000 & 3,170 & 684 & 426 & 228 & 188 & 190 & 12,870 \\
\hline 45 & 300 & 571 & 541 & 780 & 2,980 & 3,690 & 6,160 & 5,000 & 385 & 194 & 179 & 212 & 20,990 \\
\hline 46 & 246 & 744 & 3,330 & 5,160 & 4,000 & 8,060 & 12,500 & 11,400 & 1,400 & 228 & 194 & 222 & 47,480 \\
\hline 47 & 403 & 1,840 & 10,400 & 2,810 & 9,950 & 7,490 & 7,340 & 2,300 & 385 & 218 & 165 & 313 & 43,610 \\
\hline 48 & 2,070 & 1,890 & 2,130 & 4,350 & 7,730 & 7,860 & 13,700 & 20,000 & 4,880 & 321 & 216 & 335 & 65,480 \\
\hline 49 & 748 & 1,500 & 1,745 & 1,141 & 6,320 & 11,000 & 16,800 & 12,900 & 847 & 159 & 141 & 163 & 53,460 \\
\hline 50 & 873 & 1,050 & 1,060 & 1,190 & 6,380 & 10,600 & 12,400 & 15,500 & 7,070 & 2,050 & 1,060 & 988 & 60,220 \\
\hline 51 & 2,120 & 6,660 & 11,900 & 9,130 & 17,500 & 8,870 & 21,200 & 17,300 & 5,640 & 2,350 & 1,530 & 1,420 & 105,600 \\
\hline 52 & 2,060 & 2,480 & 5,400 & 3,600 & 9,370 & 7,190 & 17,800 & 11,400 & 3,930 & 2,010 & 1,430 & 1,340 & 68,010 \\
\hline 53 & 1,400 & 1,800 & 2,260 & 18,500 & 7,950 & 5,860 & 12,700 & 16,300 & 6,060 & 2,440 & 1,620 & 1,440 & 78,330 \\
\hline 54 & 1,880 & 2,390 & 4,140 & 4,370 & 9,160 & 11,900 & 20,800 & 17,000 & 6,010 & 2,500 & 1,660 & 1,500 & 83,310 \\
\hline 55 & 1,920 & 2,320 & 2,220 & 2,210 & 2,390 & 2,840 & 5,230 & 9,770 & 4,300 & 1,630 & 900 & 972 & 36,700 \\
\hline 56 & 1,740 & 3,500 & 13,500 & 7,910 & 5,150 & 16,300 & 35,400 & 32,200 & 10,100 & 3,250 & 1,910 & 1,670 & 132,600 \\
\hline 57 & 1,980 & 2,130 & 2,490 & 1,820 & 3,490 & 8,990 & 13,700 & 11,400 & 2,560 & 1,510 & 1,200 & 1,130 & 52,400 \\
\hline 58 & 1,890 & 1,950 & 3,310 & 5,270 & 15,300 & 9,470 & 13,600 & 14,000 & 3,440 & 1,690 & 1,080 & 1,270 & 72,270 \\
\hline 59 & 1,890 & 3,060 & 3,230 & 11,500 & 5,450 & 9,950 & 13,500 & 8,490 & 3,060 & 1,520 & 1,140 & 1,290 & 64,080 \\
\hline 60 & 1,540 & 1,830 & 2,070 & 2,060 & 4,940 & 8,300 & 12,600 & 10,700 & 3,690 & 1,400 & 1,030 & 1,010 & 51,170 \\
\hline 61 & 1,210 & 2,460 & 1,530 & 3,580 & 14,300 & 11,900 & 12,000 & 11,100 & 4,350 & 1,690 & 990 & 819 & 65,930 \\
\hline 62 & 1,570 & 1,940 & 2,530 & 3,290 & 4,010 & 4,350 & 13,600 & 8,480 & 3,240 & 1,320 & 944 & 722 & 46,000 \\
\hline 63 & 1,780 & 5,210 & 6,670 & 2,320 & 9,320 & 5,930 & 14,100 & 11,400 & 3,050 & 1,780 & 1,290 & 1,070 & 63,920 \\
\hline 64 & 1,300 & 2,590 & 2,050 & 4,250 & 3,660 & 3,230 & 6,410 & 5,550 & 2,920 & 1,280 & 889 & 778 & 34,910 \\
\hline 65 & 932 & 1,160 & 4,550 & 7,770 & 7,110 & 7,860 & 11,800 & 8,550 & 3,070 & 1,590 & 1,320 & 924 & 56,640 \\
\hline 66 & 1,010 & 1,470 & 1,390 & 4,390 & 2,320 & 8,160 & 14,400 & 9,820 & 3,060 & 1,770 & 1,000 & 952 & 49,740 \\
\hline 67 & 952 & 1,920 & 4,920 & 6.630 & 7,640 & 6,660 & 9,030 & 13,900 & 5,110 & 1,720 & 996 & 797 & 60,280 \\
\hline 68 & 710 & 1,430 & 2,430 & 5,500 & 12,800 & 10,400 & 6,020 & 5,540 & 2,040 & $1,0 \cup 0$ & 1,010 & 1,030 & 49,910 \\
\hline 69 & 1,500 & 3,100 & 3,230 & 5,860 & 3,340 & 11,100 & 19,200 & 15,200 & 3,870 & 1,720 & 1,160 & 1,090 & 70,370 \\
\hline 70 & 1,390 & 1,610 & 2,470 & 8,140 & 8,230 & 11,400 & 10,500 & 12,000 & 3,970 & 1,690 & 1,090 & 1,070 & 63,560 \\
\hline 71 & 1,440 & 1,580 & 4,130 & 11,200 & 9,770 & 7,920 & 14,000 & 22,100 & 7,420 & 2,770 & 1,720 & 1,550 & 85,600 \\
\hline 72 & 1,690 & 1,770 & 2,240 & 6,520 & 8,570 & 21,300 & 11,500 & 14,700 & 5,560 & 2,300 & 1,750 & 1,490 & 79,390 \\
\hline
\end{tabular}


APPENDIX II.--Monthly and annual surface-water discharges at selected sites in the Toppenish Creek basin as shown in figure 4 and listed in table 1 --Continued

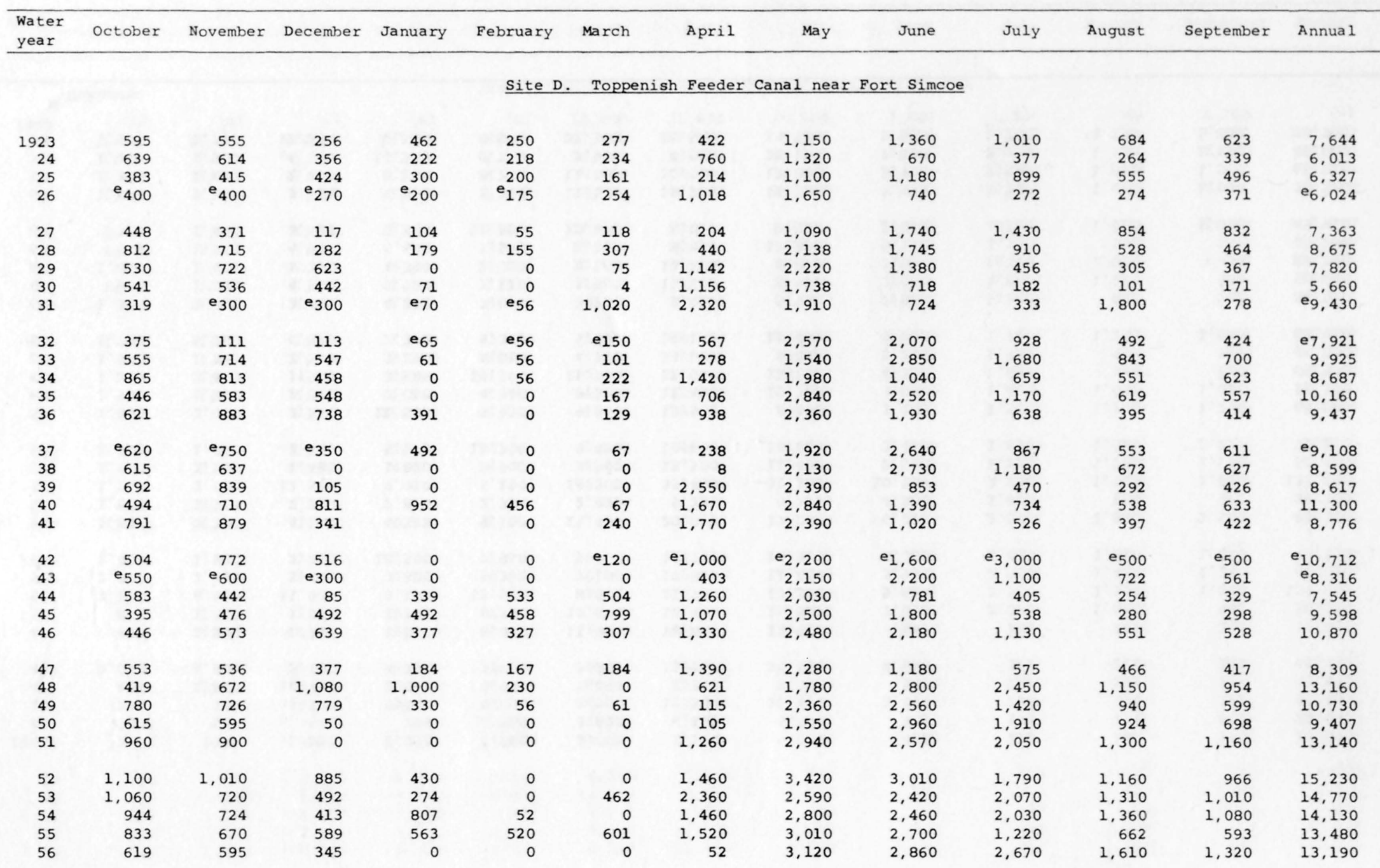




\begin{tabular}{|c|c|c|c|c|c|c|c|c|c|c|c|c|c|}
\hline 1957 & 1,200 & 655 & 664 & 538 & 611 & 785 & 879 & 3,400 & 2,260 & 1,330 & 1,040 & 833 & 14,200 \\
\hline 58 & 1,060 & 807 & 637 & 534 & 314 & 655 & 1,510 & 4,410 & 3,030 & 1,500 & 900 & 873 & 16,230 \\
\hline 59 & 1,100 & 833 & 841 & 839 & 641 & 676 & 1,430 & 4,190 & 2,790 & 1,330 & 958 & 448 & 16,080 \\
\hline 60 & 952 & 1,020 & 1,050 & 1,050 & 978 & 1,080 & 1,970 & 3,330 & 2,620 & 1,260 & 970 & 948 & 17,230 \\
\hline 61 & 1,020 & 581 & 534 & 944 & 593 & 182 & 1,380 & 3,100 & 3,020 & 1,690 & 990 & 736 & 14,770 \\
\hline 62 & 738 & 641 & 536 & 476 & 389 & 430 & 1,860 & 3,110 & 2,480 & 1,320 & 944 & 690 & 13,610 \\
\hline 63 & 1,290 & 1,210 & 1,160 & 1,060 & 795 & 1,010 & 1,450 & 2,960 & 3,050 & 1,780 & 1,290 & 1,070 & 18,130 \\
\hline 64 & 829 & 732 & 821 & 881 & 978 & 1,190 & 2,530 & 3,510 & 2,840 & 1,280 & 889 & 778 & 17,260 \\
\hline 65 & 932 & 476 & 710 & 212 & 258 & 926 & 3,400 & 3,410 & 2,690 & 1,530 & 1,260 & 865 & 16,670 \\
\hline 66 & 589 & 426 & 397 & 264 & 668 & 1,300 & 1,940 & 3,730 & 2,880 & 1,710 & 940 & 893 & 15,740 \\
\hline 67 & 924 & 910 & 869 & 676 & 651 & 2,270 & 2,430 & 3,410 & 3,220 & 1,720 & 996 & 797 & 18,870 \\
\hline 68 & 744 & 464 & 736 & 553 & 282 & 1,540 & 2,780 & 3,100 & 2,000 & 1,000 & 1,010 & 1,030 & 15,240 \\
\hline 69 & 1,080 & 1,030 & 891 & 593 & 472 & 420 & 1,490 & 2,980 & 2,760 & 1,720 & 1,160 & 1,090 & 15,690 \\
\hline 70 & 1,270 & 1,280 & 920 & 708 & 218 & 246 & 2,120 & 3,540 & 3,050 & 1,690 & 1,090 & 1,070 & 17,200 \\
\hline 71 & 1,100 & 678 & 1,430 & 1,330 & 1,030 & 1,180 & 1,600 & 3,600 & 3,220 & 2,770 & 1,720 & 1,550 & 21,210 \\
\hline 72 & 1,690 & 1,430 & 1,350 & 1,260 & 906 & 0 & 1,030 & 3,310 & 3,270 & 2,300 & 1,750 & 1,490 & 19.790 \\
\hline & timate & & & & & & & & & & & & \\
\hline
\end{tabular}

운

Site G. Simcoe Creek Flume near Fort Simcoe

\begin{tabular}{|c|c|c|c|c|c|c|c|c|c|c|c|c|c|}
\hline 1920 & (u) & (u) & (u) & (u) & (u) & (u) & (u) & 123 & 208 & 92.2 & 30.7 & 23.8 & (u) \\
\hline 21 & 0 & 0 & 61.5 & 184 & 278 & 246 & 179 & 492 & 246 & 61.5 & 61.5 & 59.5 & 1,869 \\
\hline 22 & 6.2 & 17.9 & 0 & 0 & 0 & 0 & 11.9 & 307 & 357 & 92.2 & 43.0 & 29.8 & 865 \\
\hline 23 & 24.6 & 6.0 & 0 & 0 & 0 & 0 & 357 & 307 & 268 & 184 & 92.2 & 29.8 & 1,269 \\
\hline 32 & 0 & 0 & 0 & 0 & 0 & 0 & 432 & 518 & 280 & 95.2 & 21.8 & 0 & 1,347 \\
\hline 33 & 0 & 0 & 0 & 0 & 0 & 67.4 & 395 & 571 & 438 & 127 & 53.6 & 39.7 & 1,692 \\
\hline 34 & 37.7 & 0 & 0 & 0 & 0 & 133 & 524 & 210 & 73.4 & 61.5 & 21.8 & 0 & 1,061 \\
\hline 35 & 639 & 0 & 0 & 0 & 0 & 121 & 694 & 799 & 296 & 97.2 & 61.5 & 27.8 & 2,736 \\
\hline 36 & 0 & 0 & 0 & 0 & 0 & 0 & 381 & 712 & 379 & 91.2 & 61.5 & 59.5 & 1,684 \\
\hline 37 & 0 & 0 & 0 & 0 & 0 & 0 & 309 & 825 & 371 & 182 & 75.4 & 59.5 & 1,822 \\
\hline 38 & 61.5 & 59.5 & 0 & 61.5 & 0 & 0 & 113 & 799 & 666 & 222 & 87.3 & 25.8 & 2,096 \\
\hline 39 & 0 & 0 & 0 & 0 & 0 & 15.9 & 494 & 264 & 143 & 75.4 & 61.5 & 49.6 & 1,103 \\
\hline 40 & 0 & 0 & 0 & 0 & 15.9 & 37.7 & 490 & 494 & 216 & 99.2 & 61.5 & 0 & 1,414 \\
\hline 41 & 0 & 0 & 61.5 & 0 & 71.4 & 0 & 476 & 300 & 141 & 65.5 & 61.5 & 23.8 & 1,201 \\
\hline 42 & 0 & 59.5 & 61.5 & 0 & 0 & 0 & 409 & 538 & 284 & 186 & 95.2 & 39.7 & 1,673 \\
\hline 43 & 0 & 59.5 & 61.5 & 61.5 & 55.5 & 61.5 & 69.4 & 609 & 393 & 341 & 169 & 75.4 & 1,956 \\
\hline 44 & 61.5 & 59.5 & 0 & 0 & 0 & 0 & 254 & 270 & 202 & 115 & 61.5 & 11.9 & 1,035 \\
\hline 45 & 0 & 0 & 0 & 0 & 0 & 0 & 159 & 659 & 395 & 171 & 69.4 & 33.7 & $\begin{array}{l}1,487 \\
1\end{array}$ \\
\hline 46 & 0 & 0 & 0 & 0 & 0 & 0 & 73.4 & 613 & 464 & 222 & 83.3 & 59.5 & 1,515 \\
\hline
\end{tabular}


APPENDIX II.--Monthly and annual surface-water discharges at selected sites in the Toppenish Creek basin as shown in figure 4 and listed in table 1--Continued

\begin{tabular}{|c|c|c|c|c|c|c|c|c|c|c|c|c|c|}
\hline $\begin{array}{l}\text { Water } \\
\text { year }\end{array}$ & October & November & December & January & February & March & April & May & June & Jul $_{Y}$ & August & September & Annual \\
\hline 1947 & 61.5 & 59.5 & 61.5 & 61.5 & 55.5 & 61.5 & 315 & 545 & 411 & 151 & 37.7 & 0 & 1,821 \\
\hline 48 & 0 & 0 & 0 & 0 & 0 & 0 & 176 & 657 & 399 & 363 & 204 & 119 & 1,918 \\
\hline 49 & 0 & 119 & 0 & 0 & 0 & 0 & 103 & 633 & 450 & 147 & 83.3 & 35.7 & 1,571 \\
\hline 50 & 0 & 59.5 & 0 & 0 & 0 & 0 & 0 & 639 & 472 & 361 & 186 & 59.5 & 1,777 \\
\hline 51 & 33.7 & 0 & 0 & 0 & 0 & 61.5 & 329 & 791 & 579 & 357 & 135 & 69.4 & 2,356 \\
\hline 52 & 123 & 75.4 & 0 & 0 & 0 & 19.8 & 643 & 996 & 458 & 214 & 81.3 & 0 & 2,611 \\
\hline 53 & 0 & 0 & 0 & 0 & 0 & 428 & 732 & 863 & 422 & 347 & 196 & 121 & 3,109 \\
\hline 54 & 61.5 & 59.5 & 0 & 0 & 0 & 0 & 252 & 936 & 662 & 381 & 188 & 119 & 2,659 \\
\hline 55 & 115 & 59.5 & 0 & 0 & 0 & 0 & 343 & 849 & 734 & 363 & 184 & 179 & 2,827 \\
\hline 56 & 91.2 & 0 & 0 & 0 & 0 & 0 & 357 & 805 & 655 & 407 & 234 & 119 & 2,668 \\
\hline 57 & 123 & 0 & 0 & 0 & 0 & 0 & 288 & 980 & 520 & 284 & 147 & 89.3 & 2,431 \\
\hline 58 & 61.5 & 59.5 & 0 & 0 & 0 & 41.6 & 341 & 960 & 545 & 226 & 91.2 & 59.5 & 2,385 \\
\hline 59 & 61.5 & 59.5 & 0 & 0 & 0 & 430 & 1,140 & 746 & 307 & 163 & 89.3 & 0 & 2,996 \\
\hline 60 & 0 & 0 & 0 & 0 & 0 & 0 & 543 & 1,100 & 718 & 294 & 153 & 89.3 & 2,897 \\
\hline 61 & 61.5 & 0 & 0 & 0 & 0 & 0 & 422 & 1,260 & 855 & 202 & 224 & 89.3 & 3,114 \\
\hline 62 & 61.5 & 0 & 0 & 0 & 0 & 0 & 486 & 1,100 & 722 & 311 & 173 & 89.3 & 2,943 \\
\hline 63 & 61.5 & 0 & 0 & 0 & 0 & 0 & 89.3 & 1,380 & 756 & 319 & 135 & 89.3 & 2,830 \\
\hline 64 & 61.5 & 0 & 0 & 0 & 0 & 105 & 611 & 680 & 783 & 381 & 363 & 179 & 3,164 \\
\hline 65 & 101 & 0 & 0 & 0 & 0 & 107 & 833 & 1,290 & 690 & 349 & 290 & 97.2 & 3,757 \\
\hline 66 & 61.5 & 0 & 0 & 0 & 0 & 0 & 833 & 1,310 & 599 & 260 & 91.2 & 59.5 & 3,214 \\
\hline 67 & 0 & 0 & 0 & 0 & 0 & 341 & 855 & 1,220 & 891 & 387 & 169 & 59.5 & 3,923 \\
\hline 68 & 0 & 0 & 0 & 0 & 0 & 210 & 831 & 918 & 611 & 282 & 91.2 & 69.4 & 3,013 \\
\hline 69 & 0 & 0 & 0 & 0 & 0 & 0 & 528 & 1,430 & 966 & 369 & 179 & 119 & 3,591 \\
\hline 70 & 81.3 & 0 & 0 & 0 & 0 & 0 & 571 & 1,210 & 746 & 262 & 101 & 59.5 & 3,031 \\
\hline 71 & 0 & 0 & 0 & 0 & 0 & 0 & 508 & 1,250 & 1,050 & 415 & 182 & 59.5 & 3,465 \\
\hline 72 & 0 & 0 & 0 & 0 & 0 & 0 & 238 & 1,470 & 1,190 & 405 & 177 & 85.3 & 3,565 \\
\hline $\mathrm{u}$ & Jnknown. & & & & & & & & & & & & \\
\hline
\end{tabular}


Station 12506500. Simcoe Creek below Spring Creek, near Fort Simcoe ${ }^{a}$

\begin{tabular}{|c|c|c|c|c|c|c|c|c|c|c|c|c|c|}
\hline 1909 & (u) & (u) & (u) & (u) & (u) & 3,810 & 3,780 & 3,620 & 750 & 98 & 6 & 2 & (u) \\
\hline 10 & 29 & 1,300 & 2,210 & 7,440 & 3,330 & 23,500 & 6,430 & 2,870 & 470 & 277 & 51.0 & 23.8 & 47,900 \\
\hline 11 & 86.7 & 208 & 338 & 246 & 383 & 1,650 & 2,580 & 2,720 & 1,680 & 203 & 98.4 & 59.5 & 10,300 \\
\hline 12 & 67.6 & 119 & 123 & 2,050 & 4,160 & 2,220 & 4,820 & 3,930 & 375 & 123 & 117 & 59.5 & 18,200 \\
\hline 13 & 117 & 190 & 283 & 1,030 & 1,850 & 1,320 & 6,430 & 5,910 & 869 & 222 & 115 & 85.7 & 18,400 \\
\hline 14 & 419 & 270 & 291 & 8,180 & 5,260 & 7,010 & 7,680 & 2,050 & 220 & 31.4 & 34.4 & 48.8 & 31,500 \\
\hline 15 & 101 & 361 & 231 & 292 & 2,950 & 5,260 & 4,870 & 1,380 & 428 & 136 & 32 & 24 & 16,100 \\
\hline 16 & 33 & 57 & 1,830 & 1,030 & 9,030 & 14,200 & 8,630 & 6,000 & 2,450 & 904 & 288 & 155 & 44,600 \\
\hline 17 & 132 & 225 & 349 & 437 & 410 & 527 & 1,090 & 3,810 & 1,430 & 277 & 100 & 33 & 8,820 \\
\hline 18 & 15 & 35 & 4,860 & 4,960 & 2,710 & 2,470 & 2,770 & 1,540 & 487 & 194 & 64 & 16 & 20,100 \\
\hline 19 & 22 & 80.9 & 186 & 2,940 & 1,970 & 3,110 & 3,840 & 1,910 & 467 & 211 & 76.9 & 30 & 14,800 \\
\hline 20 & 21.5 & 53.6 & 127 & 387 & 542 & 941 & 1,110 & 947 & 189 & 58.4 & 9.2 & 8.3 & 4,390 \\
\hline 21 & 6.1 & 16.7 & 588 & 3,510 & 5,510 & 6,270 & 4,530 & 3,810 & 940 & 199 & 116 & 39.3 & 25,500 \\
\hline 22 & 41.2 & 92.8 & 2,240 & 806 & 733 & 1,660 & 3,360 & 3,870 & 542 & 189 & 67.6 & 9.5 & 13,600 \\
\hline 23 & 12.3 & 54.1 & 129 & 4,460 & 1,230 & 2,830 & 4,020 & 2,490 & 334 & 211 & 55.3 & 30.3 & 15,900 \\
\hline
\end{tabular}

Station 12506300. North Fork Simcoe Creek near Fort Simcoe

\begin{tabular}{|c|c|c|c|c|c|c|c|c|c|c|c|c|c|}
\hline $\begin{array}{r}1971 \\
72\end{array}$ & $\begin{array}{l}324 \\
494\end{array}$ & $\begin{array}{l}371 \\
666\end{array}$ & $\begin{array}{l}541 \\
753\end{array}$ & $\begin{array}{l}3,450 \\
1,970\end{array}$ & $\begin{array}{l}2,570 \\
3,320\end{array}$ & $\begin{array}{l}1,270 \\
5,290\end{array}$ & $\begin{array}{l}2,860 \\
2,420\end{array}$ & $\begin{array}{l}3,550 \\
3,030\end{array}$ & $\begin{array}{l}1,080 \\
1,280\end{array}$ & $\begin{array}{l}440 \\
493\end{array}$ & $\begin{array}{l}274 \\
335\end{array}$ & $\begin{array}{l}350 \\
307\end{array}$ & $\begin{array}{l}17,080 \\
20,360\end{array}$ \\
\hline & \multicolumn{13}{|c|}{ Station 12506330. South Fork Simcoe Creek near Fort Simcoe } \\
\hline 1971 & 232 & 272 & 395 & 1,510 & 1,370 & 934 & 1,760 & 4,680 & 1,200 & 408 & 252 & 307 & 13,320 \\
\hline 72 & 432 & 520 & 609 & 1,020 & 2,880 & 4,200 & 1,560 & 3,990 & 1,190 & 351 & 283 & 228 & 17,260 \\
\hline
\end{tabular}

Station 12506600. Agency Creek near Fort Simcoe

\begin{tabular}{rrrrrrrrrrrrrrr}
1971 & 0 & 45.2 & 201 & 1,030 & 1,740 & 3,190 & 693 & 299 & 74.2 & 13.5 & 0 & 0 & 8,577 & 140 \\
72 & 0 & 75.6 & 469 & 2,140 & 941 & 805 & 1,460 & 835 & 141 & 42.4 & 1.6 & 0 & 6,911 & \\
\hline
\end{tabular}


APPENDIX II.--Monthly and annual surface-water discharges at selected sites in the Toppenish Creek basin as shown in figure 4 and listed in table l-continued

\begin{tabular}{|c|c|c|c|c|c|c|c|c|c|c|c|c|c|}
\hline $\begin{array}{l}\text { Water } \\
\text { year }\end{array}$ & October & November & December & January & February & March & April & May & June & July & August & September & Annual \\
\hline & \multicolumn{13}{|c|}{ Station 12507100 . Mill Creek near White Swan } \\
\hline 1971 & 0 & 9.1 & 205 & 1,590 & 362 & 698 & 607 & 204 & 79.1 & 24.4 & 0 & 0 & 3,779 \\
\hline \multicolumn{14}{|c|}{ Site V. Satus East Lateral (diverts from Toppenish Creek) } \\
\hline 1931 & $e_{2,000}$ & 0 & 0 & 0 & 0 & 845 & 4,370 & 7,141 & 6,393 & 6,232 & 8,487 & 3,497 & e 38,970 \\
\hline 33 & 2,011 & 0 & 0 & 0 & 0 & 0 & 3,150 & 5,361 & 5,790 & 6,716 & 8,716 & 3,713 & 35,460 \\
\hline 34 & 545 & 0 & 0 & 0 & 0 & 333 & 6,082 & 8,075 & 9,959 & 8,352 & 8,924 & 4,824 & 47,090 \\
\hline 35 & 936 & 0 & 0 & 0 & 0 & 0 & 4,985 & 9,112 & 6,391 & 7,240 & 8,680 & 4,171 & 41,520 \\
\hline 36 & 1,861 & 0 & 0 & 0 & 0 & 0 & 3,550 & 8,961 & 4,048 & 7,688 & 9,303 & 4,645 & 40,060 \\
\hline 37 & 2,515 & 0 & 0 & 0 & 0 & 0 & 1,906 & 10,096 & 3,396 & 8,509 & 8,317 & 4,514 & 39,250 \\
\hline 38 & 3,172 & 0 & 0 & 0 & 0 & 0 & 2,061 & 9,707 & 6,194 & 8,529 & 7,781 & 6,609 & 44,050 \\
\hline 39 & 1,236 & 0 & 0 & 0 & 0 & 0 & 6,629 & 7,849 & 7,589 & 7,857 & 7,962 & 7,216 & 46,340 \\
\hline 40 & 2,033 & 0 & 0 & 0 & 0 & 0 & 4,167 & 7,577 & 7,629 & 7,494 & 8,745 & 5,867 & 43,510 \\
\hline 41 & 1,597 & 0 & 0 & 0 & 0 & 0 & 4,505 & 9,317 & 6,621 & 6,680 & 7,093 & 6,542 & 42,360 \\
\hline 44 & 2,723 & 0 & 0 & 0 & 0 & 0 & 3,564 & 9,555 & 5,812 & 7,508 & 8,121 & 7,468 & 44,750 \\
\hline 45 & 3,560 & 0 & 0 & 0 & 0 & 0 & 3,677 & 8,487 & 5,601 & 6,788 & 7,260 & 7,361 & 42,730 \\
\hline 46 & 3,886 & 0 & 0 & 0 & 0 & 0 & 1,795 & 9,906 & 5,921 & 6,960 & 7,277 & 5,439 & 41,180 \\
\hline 47 & 2,832 & 0 & 0 & 0 & 0 & 0 & 7,172 & 7,143 & 7,831 & 7,111 & 7,150 & 6,780 & 46,020 \\
\hline 48 & 2,543 & 0 & 0 & 0 & 0 & 0 & 2,321 & 8,059 & 4,479 & 7,839 & 9,392 & 5,724 & 40,360 \\
\hline 49 & 3,152 & 0 & 0 & 0 & 0 & 0 & 3,463 & 10,354 & 7,273 & 7,537 & 7,462 & 7,158 & 46,400 \\
\hline 50 & 2,547 & 0 & 0 & 0 & 0 & 0 & 3,154 & 9,207 & 4,514 & 8,797 & 8,811 & 5,217 & 42,250 \\
\hline 51 & 1,968 & 0 & 0 & 0 & 0 & 0 & 3,862 & 8,573 & 5,252 & 6,938 & 9,892 & 5,068 & 41,550 \\
\hline 52 & 1,646 & 0 & 0 & 0 & 0 & 0 & 5,395 & 9,691 & 5,726 & 7,389 & 8,676 & 6,710 & 45,230 \\
\hline 53 & 3,705 & 0 & 0 & 0 & 0 & 0 & 4,798 & 7,113 & 4,245 & 7,361 & 9,553 & 5,246 & 42,020 \\
\hline 54 & 4,058 & 0 & 0 & 0 & 0 & 0 & 3,868 & 8,289 & 4,334 & 7,742 & 9,211 & 4,235 & 41,740 \\
\hline 55 & 2,122 & 0 & 0 & 0 & 0 & 387 & 4,893 & 5,851 & 5,300 & 6,776 & 9,919 & 2,918 & 38,170 \\
\hline 56 & 1,682 & 0 & 0 & 0 & 0 & 0 & 2,638 & 7,107 & 4,056 & 7,494 & 9,959 & 3,485 & 36,420 \\
\hline 57 & 1,684 & 0 & 0 & 0 & 0 & 0 & 250 & 6,266 & 7,140 & 8,608 & 7,309 & 4,245 & 35,500 \\
\hline 58 & 809 & 0 & 0 & 0 & 0 & 0 & 153 & 6,627 & 6,768 & 8,049 & 7,686 & 3,777 & 33,870 \\
\hline 59 & 1,751 & 0 & 0 & 0 & 0 & 0 & 2,876 & 6,323 & 6,300 & 7,494 & 7,813 & 3,836 & 36,390 \\
\hline 60 & $e_{1,700}$ & 0 & 0 & 0 & 0 & 0 & 2,535 & 6,869 & 6,321 & 8,733 & 7,985 & 4,659 & e 38,800 \\
\hline
\end{tabular}




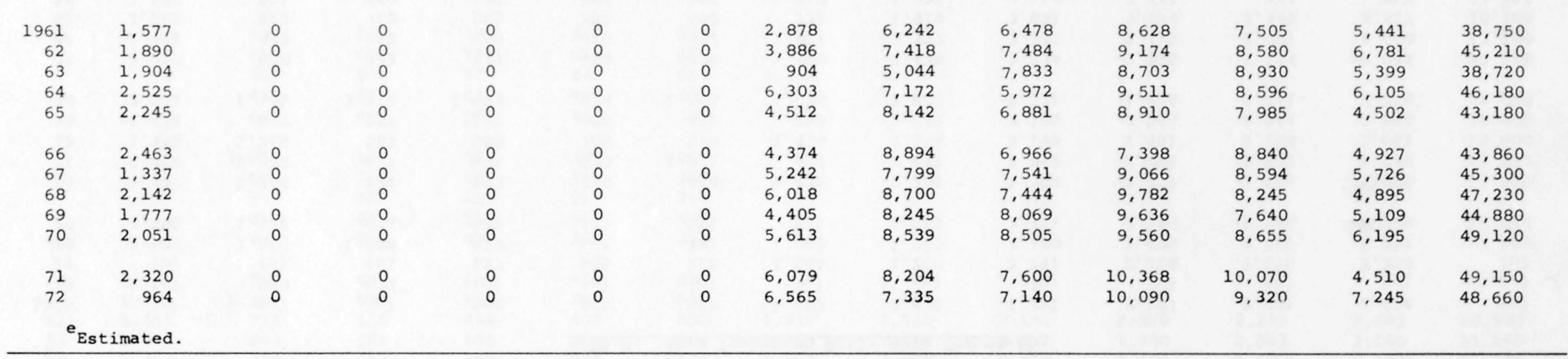

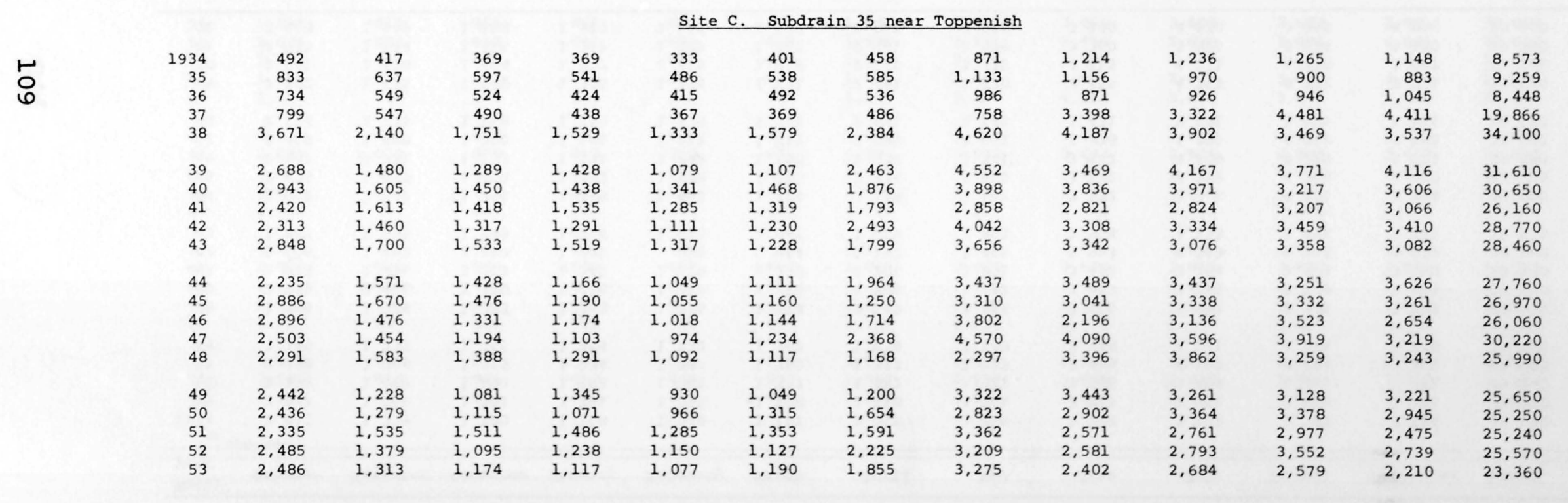


APPENDIX II.--Monthly and annual surface-water discharges at selected sites in the Toppenish Creek basin as shown in figure 4 and listed in table 1--Continued

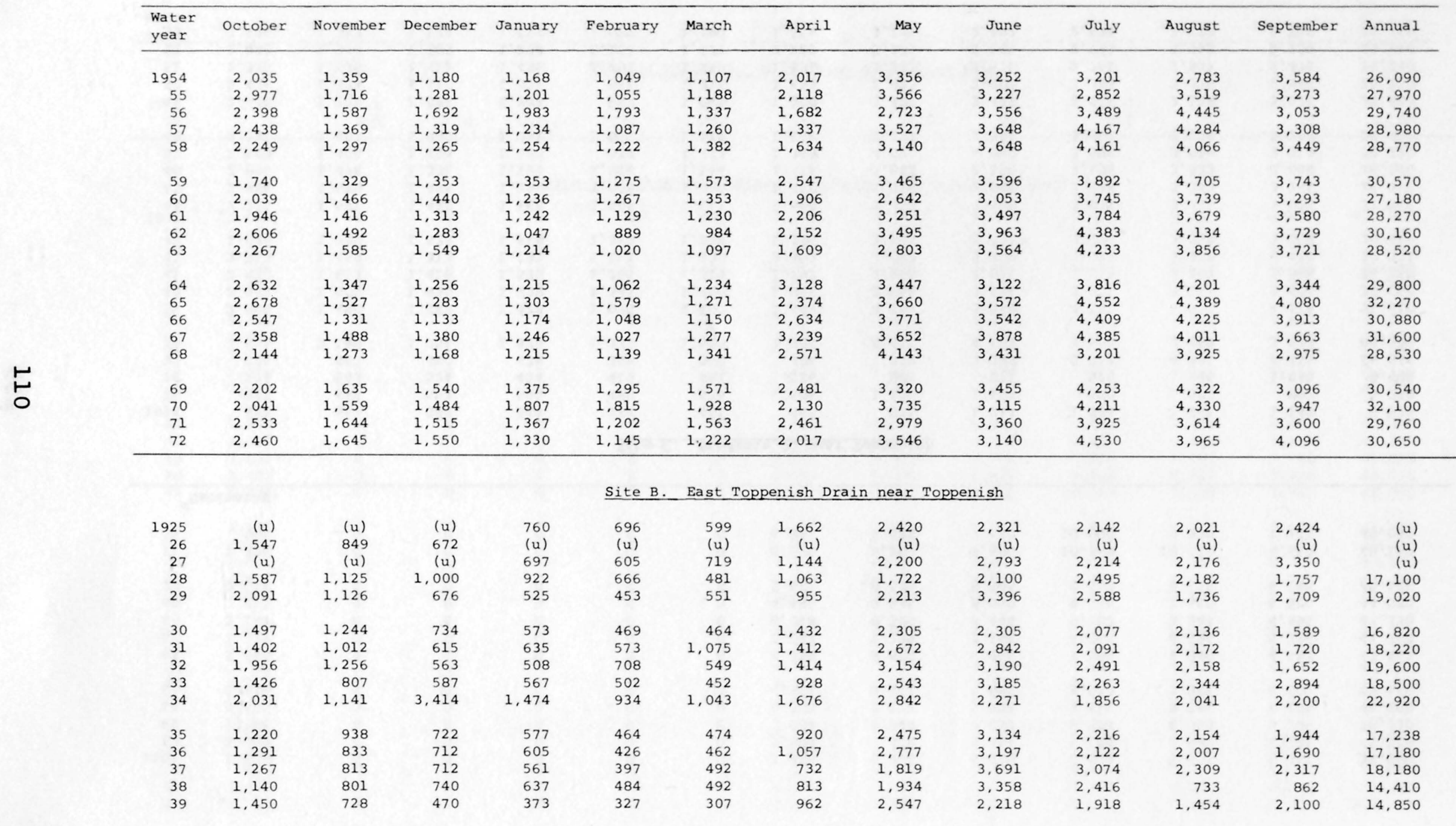




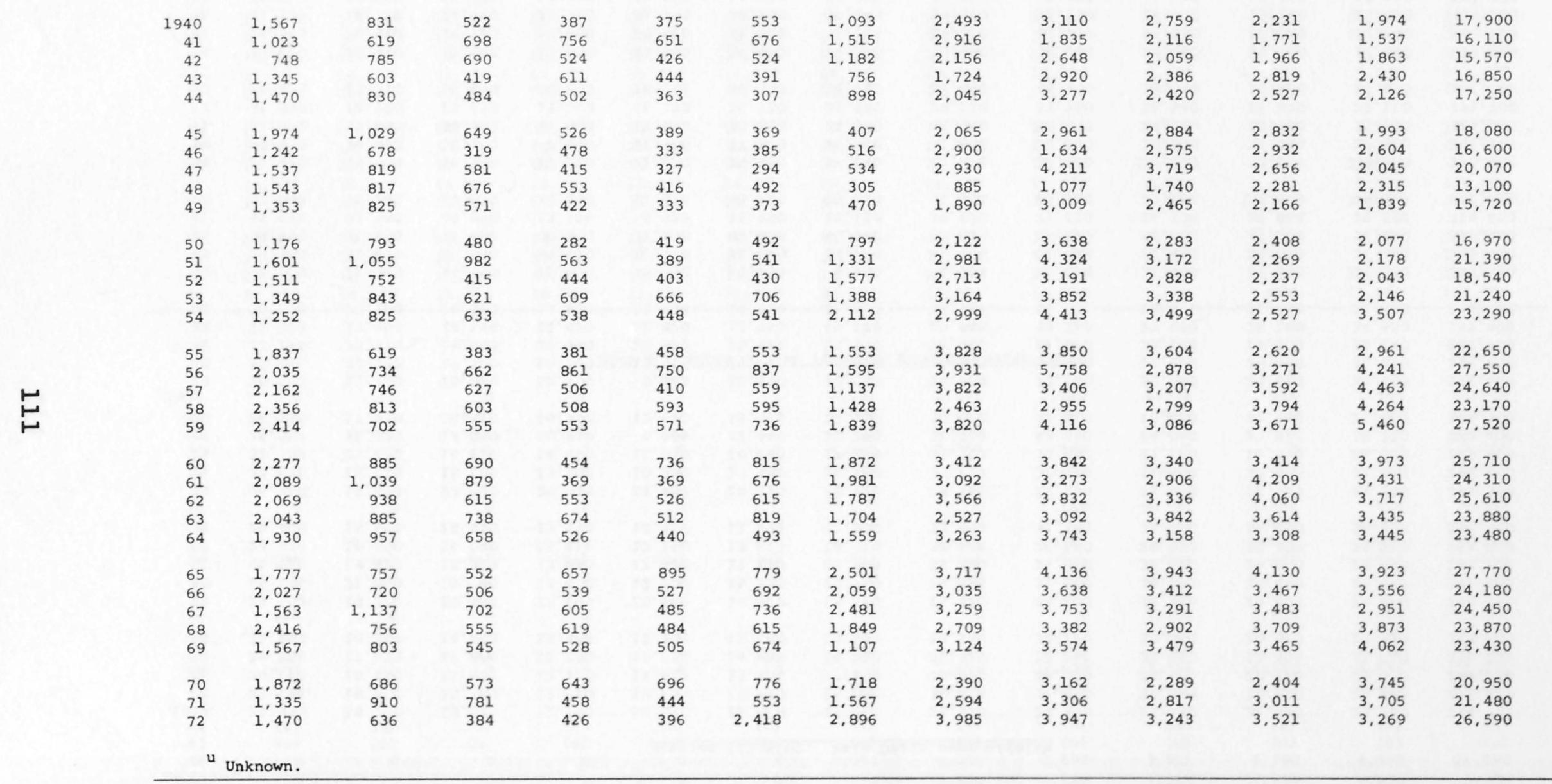


APPENDIX II.--Monthly and annual surface-water discharges at selected sites in the Toppenish Creek basin as shown in figure 4 and listed in table $1--$ Continued

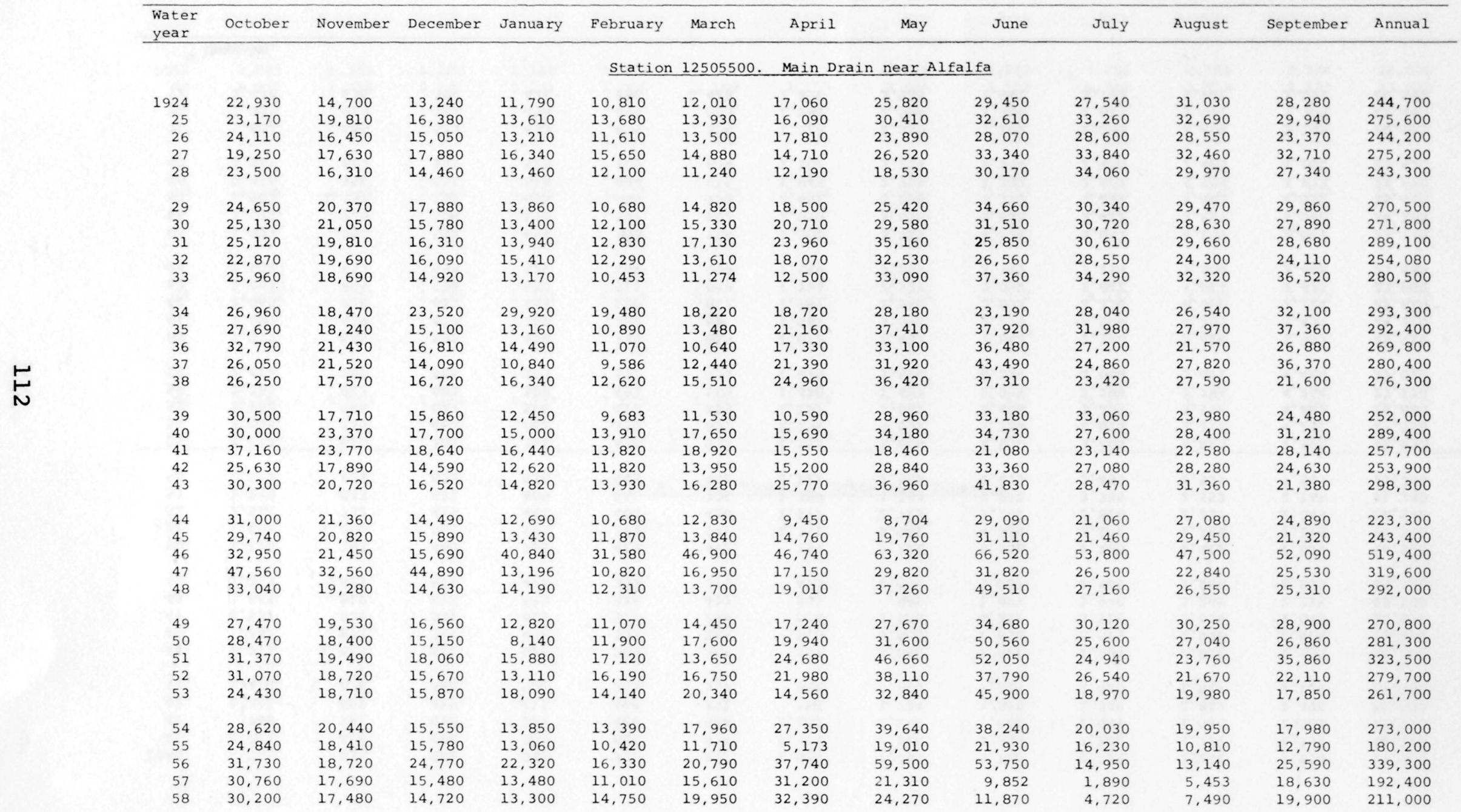




\begin{tabular}{|c|c|c|c|c|c|c|c|c|c|c|c|c|c|}
\hline 1959 & 23,550 & 17,200 & 15,200 & 15,500 & 12,350 & 17,850 & 24,440 & 24,590 & 24,120 & 8,555 & 5,465 & 20,830 & 209,600 \\
\hline 60 & 30.780 & 16,790 & 13,960 & 11,740 & 11,700 & 12,330 & 23,560 & 23,900 & 17.690 & 2,216 & 8,773 & 16,310 & 189,700 \\
\hline 61 & 24,190 & 17,220 & 14,780 & 12,590 & 15,540 & 17,560 & 25,310 & 36,790 & 22,420 & 6,565 & 6,480 & 7,391 & 206,800 \\
\hline 62 & 25,560 & 16,800 & 14,550 & 13,390 & 10,960 & 11,970 & 25,110 & 29,160 & 22,270 & 4,643 & 11,240 & 8,690 & 194,300 \\
\hline 63 & 30,390 & 19,560 & 16,570 & 13,140 & 15,090 & 17,840 & 23,780 & 21,030 & 5,952 & 5,409 & 7,581 & 9,914 & 186,300 \\
\hline 64 & 21,140 & 16,940 & 14,500 & 12,750 & 10,960 & 13,960 & 5,736 & 11,010 & 28,220 & 6,859 & 8,727 & 7,855 & 158,700 \\
\hline 65 & 20,700 & 17,600 & 13,770 & 10,970 & 21,580 & 16,560 & 26,270 & 27,140 & 25,300 & 6,922 & 8,232 & 9,422 & 204,500 \\
\hline 66 & 25,530 & 16,940 & 14,620 & 14,590 & 11,320 & 14,360 & 28,710 & 21,490 & 21,200 & 10,610 & 6.097 & 11,730 & 197,200 \\
\hline 67 & 26,430 & 16,360 & 15,680 & 13,460 & 11,430 & 16,370 & 22,460 & 26,030 & 19,550 & 4,903 & 6,391 & 6,980 & 186,000 \\
\hline 68 & 25,980 & 16,910 & 15,000 & 13,950 & 14,360 & 19,290 & 14,390 & 8,376 & 10,100 & 960 & 11,080 & 18,440 & 168,800 \\
\hline 69 & 24,600 & 16,850 & 15,300 & 13,580 & 12,200 & 19,310 & 32,030 & 40,030 & 20,130 & 2,283 & 3,233 & 7,270 & 206,800 \\
\hline 70 & 22,750 & 16,400 & 15,360 & 19,310 & 17,460 & 20,520 & 25,400 & 19,400 & 14,540 & 2,208 & 4,294 & 8,140 & 185,800 \\
\hline 71 & 17,460 & 16,770 & 15,220 & 19,980 & 15,210 & 14,180 & 16,590 & 25,880 & 24,810 & 4,907 & 4,005 & 12,540 & 187,600 \\
\hline 72 & 20,920 & 16,400 & 15,410 & 14,120 & 12,410 & 31,010 & 24,300 & 18,880 & 19,330 & 6,682 & 6,680 & 11,650 & 197,800 \\
\hline
\end{tabular}

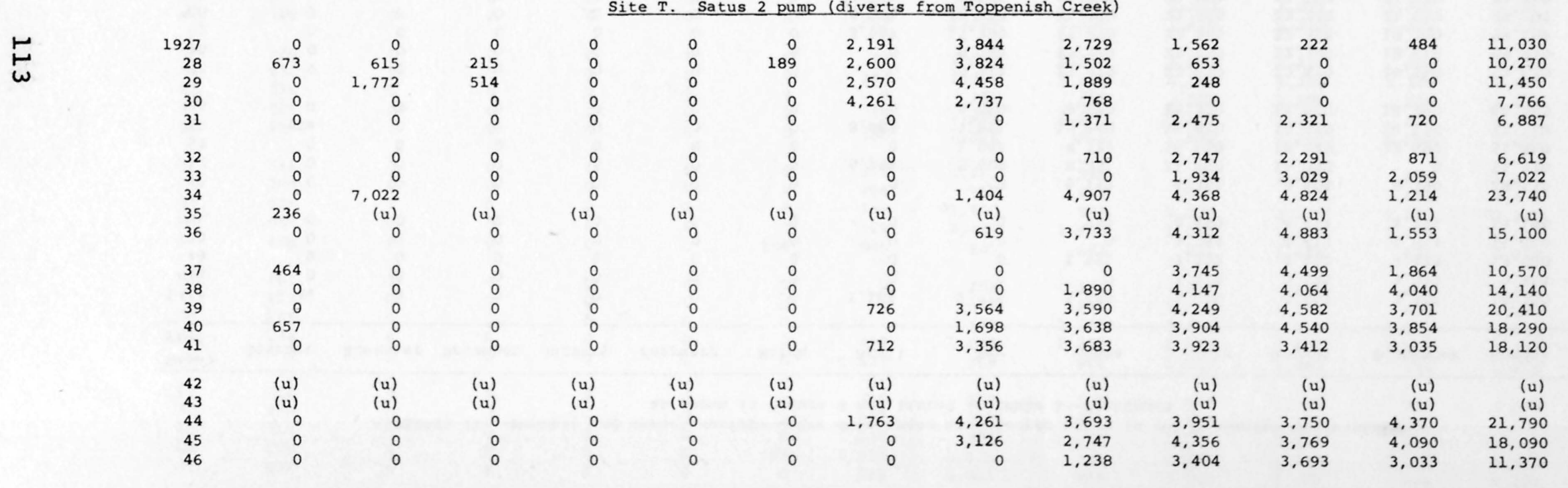


APPENDIX II.--Monthly and annual surface-water discharges at selected sites in the Toppenish Creek basin as shown in figure 4 and listed in table 1--Continued

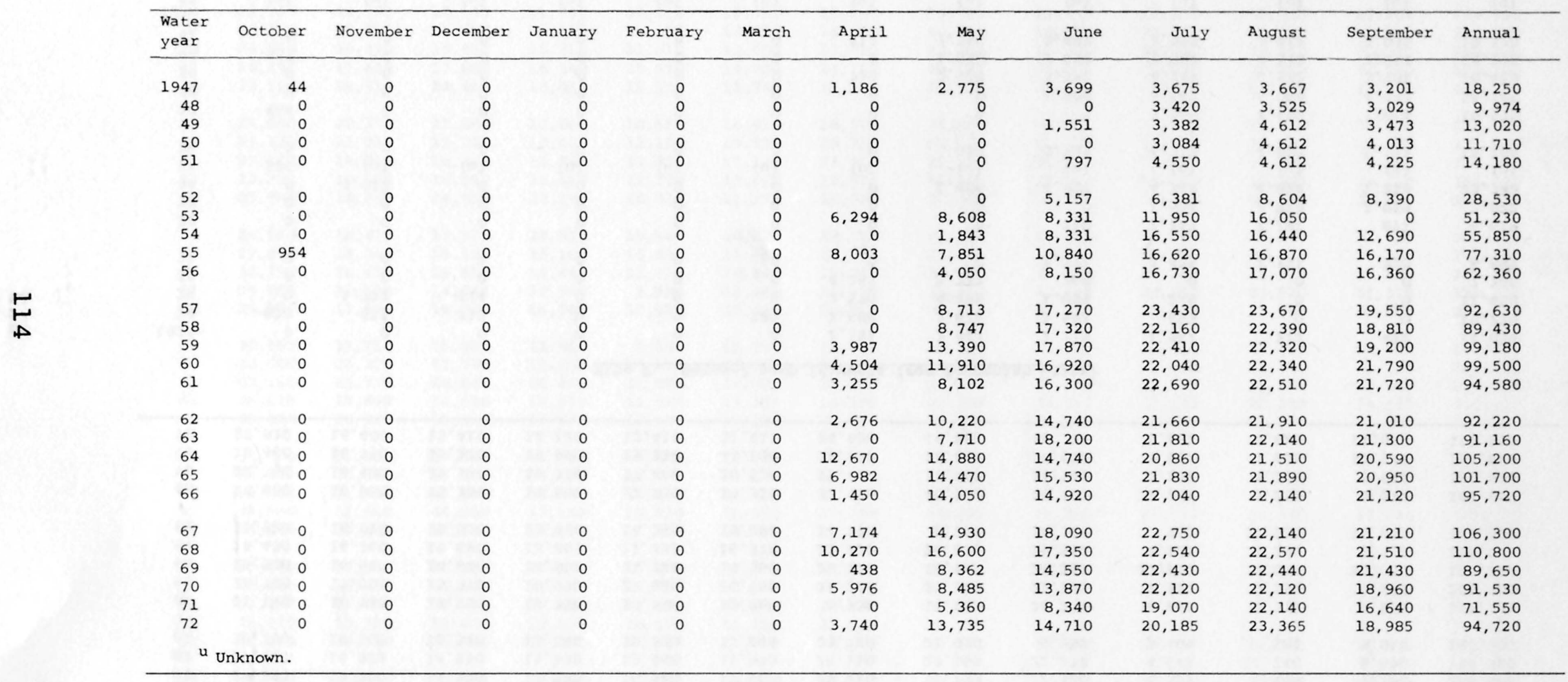


Site U. Satus West Lateral (diverts from Toppenish Creek)

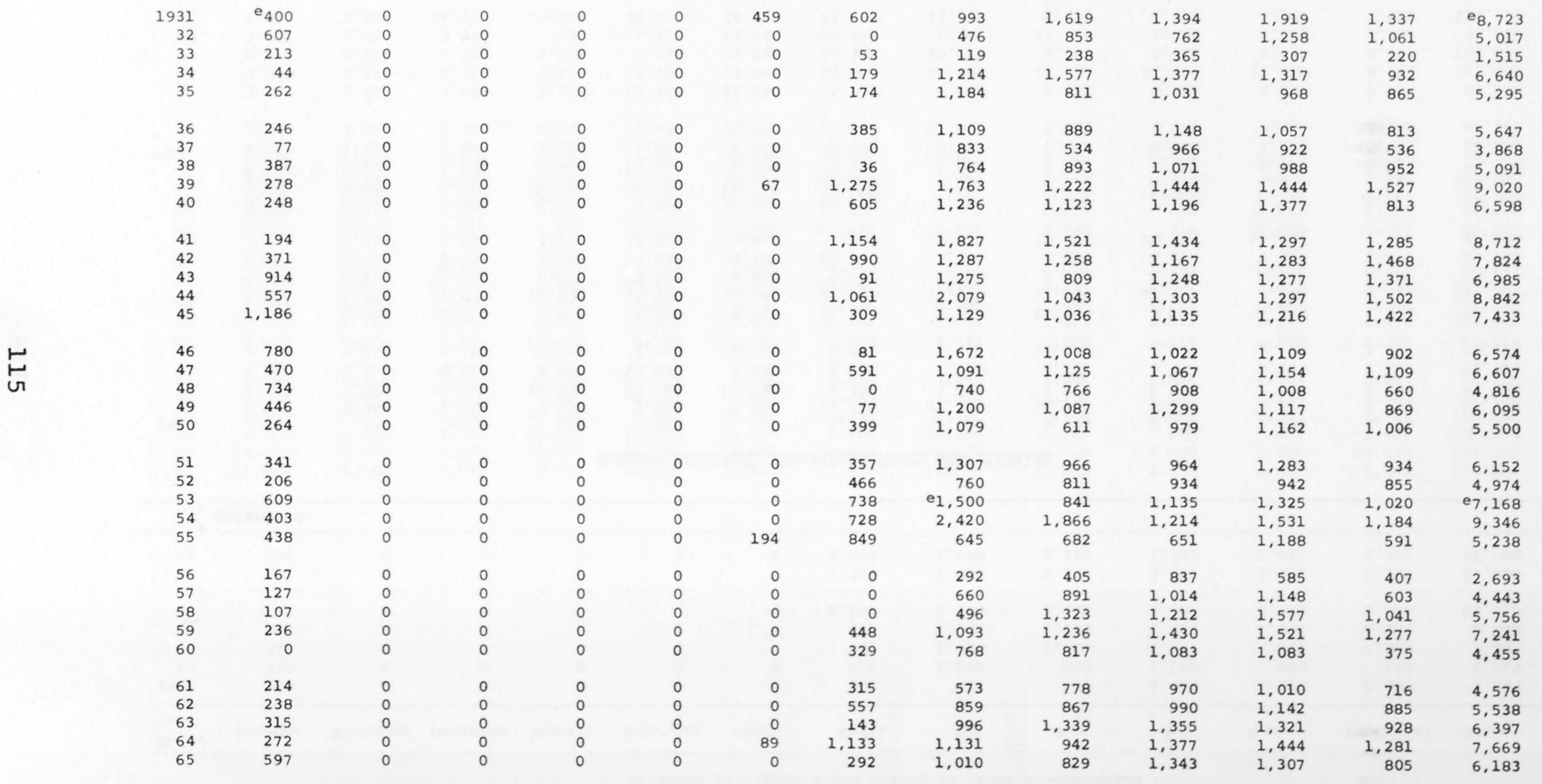


APPENDIX II.--Monthly and annual surface-water discharges at selected sites in the Toppenish Creek basin as shown in figure 4 and listed in table 1--Continued

\begin{tabular}{|c|c|c|c|c|c|c|c|c|c|c|c|c|c|}
\hline $\begin{array}{l}\text { Water } \\
\text { year }\end{array}$ & October & November & December & January & February & March & April & May & June & July & August & September & Annual \\
\hline 1966 & 298 & 0 & 0 & 0 & 0 & 0 & 365 & 875 & 990 & 1,468 & 1,938 & 1,000 & 6,934 \\
\hline 67 & 335 & 0 & 0 & 0 & 0 & 0 & 575 & 1,198 & 950 & 1,129 & 1,490 & 942 & 6,619 \\
\hline 68 & 361 & 0 & 0 & 0 & 0 & 0 & 942 & 1,434 & 1,246 & 1,517 & 1,480 & 1,085 & 8,065 \\
\hline 69 & 295 & 0 & 0 & 0 & 0 & 0 & 476 & 1,093 & 1,291 & 1,452 & 1,311 & 1,031 & 6,949 \\
\hline 70 & 347 & 0 & 0 & 0 & 0 & 0 & 1,236 & 1,630 & 2,125 & 2,186 & 2,095 & 1,426 & 11,050 \\
\hline 71 & 502 & 0 & 0 & 0 & 0 & 0 & 1,763 & 1,980 & 2,335 & 2,281 & 2,458 & 1,335 & 12,650 \\
\hline 72 & 234 & 0 & 0 & 0 & 0 & 0 & 1,405 & 1,589 & 2,285 & 2,366 & 1,855 & 1,265 & 11,000 \\
\hline
\end{tabular}

Station 12507510. Toppenish Creek near Alfalfa

\begin{tabular}{|c|c|c|c|c|c|c|c|c|c|c|c|c|c|}
\hline 1932 & (u) & (u) & (u) & (u) & (u) & (u) & 5,260 & 13,250 & 9,796 & 5,570 & 5,094 & 4,725 & (u) \\
\hline 33 & 5,054 & 2,892 & 2,910 & 3,193 & 2,765 & 5,090 & 13,240 & 22,350 & 15,610 & 5,566 & 4,867 & 5,816 & 89,350 \\
\hline 34 & 6,569 & 3,592 & 14,790 & 26,150 & 13,340 & 9,344 & 4,086 & 4,842 & 2,416 & 4,017 & 2,993 & 3,505 & 95,640 \\
\hline$\vdash$ & 3,634 & 3,300 & 4,046 & 8,914 & 13,270 & 8,440 & 6,968 & 7,718 & 6,143 & 3,977 & 3,747 & 2,763 & 72,920 \\
\hline बே & 2,949 & 3,263 & 3,122 & 3,985 & 2,664 & 8,583 & 6,062 & 5,742 & 13,930 & 3,035 & 2,696 & 2,475 & 58,510 \\
\hline 37 & 4,017 & 2,723 & 2,519 & 1,833 & 3,166 & 6,875 & 16,030 & 6,016 & 14,440 & 3,628 & 4,848 & 5,490 & 71,590 \\
\hline 38 & 2,041 & 2,817 & 3,477 & 16,500 & 11,050 & 28,040 & 24,640 & 17,190 & 12,290 & 12,480 & 7,888 & 8,616 & 147,000 \\
\hline 39 & 4,136 & 3,209 & 2,541 & 2,295 & 2,214 & 2,656 & 5,367 & 5,724 & 3,931 & 6,198 & 6,371 & 4,007 & 48,650 \\
\hline 40 & 2,628 & 2,452 & 2,735 & 2,701 & 4,447 & 21,000 & 15,740 & 4,600 & 4,262 & 5,994 & 9,697 & 9,475 & 85,730 \\
\hline 41 & 3,509 & 2,426 & 2,551 & 4,072 & 4,848 & 9,858 & 9,051 & 10,800 & 12,440 & 10,670 & 14,100 & 7,579 & 91,900 \\
\hline 42 & 3,332 & 2,551 & 3,886 & 4,227 & 8,083 & 10,510 & 11,790 & 7,501 & 6,964 & 7,228 & 5,770 & 6,218 & 78,060 \\
\hline 43 & 2,652 & 2,402 & 3,269 & 4,453 & 9,245 & 10,580 & 28,560 & 9,223 & 9,810 & 6,988 & 7,990 & 5,639 & 100,800 \\
\hline 44 & 4,449 & 3,665 & 2,894 & 2,434 & 2,384 & 2,602 & 5,322 & 7,815 & 5,022 & 7,696 & 6,972 & 8,063 & 59,320 \\
\hline 45 & 4,899 & 2,622 & 1,837 & 2,158 & 2,549 & 2,787 & 6,579 & 9,497 & 9,418 & 8,684 & 7,894 & 7,999 & 66,920 \\
\hline 46 & 2,668 & 2,650 & 2,584 & 6,541 & 5,234 & 10,030 & 11,640 & 11,960 & 7,966 & 8,130 & 9,898 & 5,205 & 84,510 \\
\hline 47 & 3,777 & 2,832 & 9,596 & 3,110 & 10,920 & 11,470 & 5,022 & 8,618 & 6,950 & 6,365 & 4,953 & 7,781 & 81,390 \\
\hline 48 & 3,759 & 3,134 & 2,757 & 4,616 & 10,500 & 13,990 & 12,820 & 17,940 & 22,420 & 11,250 & 11,860 & 8,588 & 123,600 \\
\hline 49 & 8,275 & 4,126 & 3,336 & 2,711 & 7,325 & 23,000 & 18,990 & 10,210 & 6,710 & 5,653 & 5,839 & 4,859 & 101,000 \\
\hline 50 & 3,775 & 2,870 & 3,338 & 7,690 & 5,413 & 23,240 & 15,170 & 8,049 & 13,700 & 4,756 & 4,588 & 3,336 & 95,930 \\
\hline 51 & 4,021 & 4,804 & 16,570 & 17,920 & 38,470 & 18,830 & 20,270 & 11,790 & 9,035 & 5,958 & 4,873 & 2,928 & 155,500 \\
\hline 52 & 3,886 & 3,338 & 5,506 & 4,274 & 17,660 & 11,700 & 10,830 & 5,806 & 4,721 & 6,389 & 7,180 & 7,389 & 88,680 \\
\hline 53 & 7,660 & 2,811 & 3,112 & 19,010 & 15,690 & 9,110 & 4,439 & 12,430 & 11,440 & 6,974 & 3,507 & 4,334 & 100,500 \\
\hline 54 & 4,066 & 2,590 & 2,642 & 3,398 & 10,900 & 18,430 & 14,790 & 9,876 & 13,500 & 4,788 & 6,244 & 12,250 & 93,470 \\
\hline 55 & 9,049 & 3,090 & 2,464 & 3,437 & 2,840 & 4,455 & 5,113 & 7,049 & 8,642 & 9,531 & 8,660 & 11,250 & 75,580 \\
\hline 56 & 3,878 & 3,777 & 19,460 & 27,920 & 15,920 & 30,700 & 35,690 & 22,990 & 13,080 & 5,286 & 2,753 & 4,209 & 185,660 \\
\hline
\end{tabular}




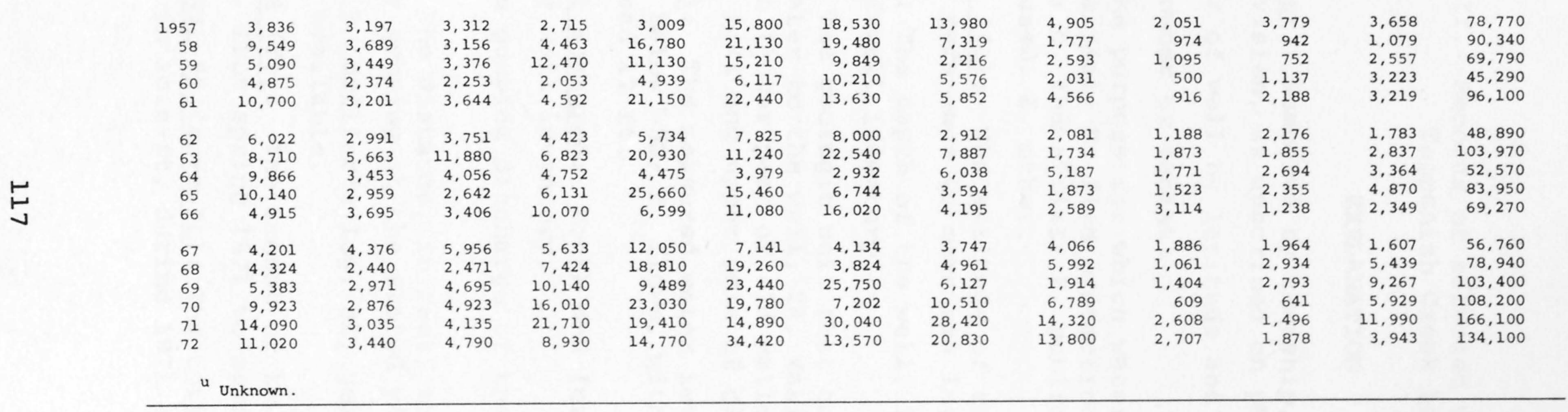


APPENDIX III.--Records of selected wells in the

Toppenish Creek basin

\section{EXPLANATION}

Local well number: Numbered by township, range, section, and 40-acre subdivision, as described on page 9.

Lat-long: Number of well by latitude and longitude.

Owner: Name of owner or tenant.

Use of water: The purpose for which water from the well is used; C, commercial; F, fire protection; H, domestic;

I, irrigation; $N$, industrial; $P$, public supply; S, stock supply; U, unused; $\mathrm{Z}$, other.

Altitude of LSD (ft): The altitude of the land-surface datum, in feet, with reference to mean sea level.

Well depth (ft): The depth of the well, in feet below LSD, at the time of well inventory.

Major aquifer: The geologic unit that contributes the greatest quantity of water to the well; YA, Yakima Basalt; EL, Ellensburg Formation (lower part of old valley fill); $O A$, alluvium (young valley fill and upper part of old valley fill).

Water level (ft): The measured water level of the well, in feet above or below LSD; F, flows, with head unknown;

+12 , flows, head $12 \mathrm{ft}$.

Date water level measured: Month and (or) year of measurement, usually during well inventory.

Yield (gpm): The pumping discharge of the well, in gallons per minute.

Drawdown (ft): The distance, in feet, that the water level was lowered by pumping at the stated yield rate.

Log available: D, driller's log; 3Z, geophysical logs; blank, no log available.

Decline, 1971-73 (ft): The amount of lowering of the water level in feet, from spring 1971 to spring 1973.

2-yr pumpage, 1971-72 (acre-ft): The total quantity of ground water pumped, in acre-ft, during 1971 and 1972 . 
APPENDIX III.--Records of selected wells in the Toppenish Creek basin--Continued

\begin{tabular}{|c|c|c|c|c|c|c|c|c|c|c|c|c|c|}
\hline $\begin{array}{l}\text { LOCAL } \\
\text { WELL } \\
\text { NUMEFR }\end{array}$ & LAT-LONG & OANER & $\begin{array}{c}\text { USE } \\
\text { OF } \\
\text { WATER }\end{array}$ & $\begin{array}{l}\text { ALTI- } \\
\text { TUDE- } \\
\text { OF LSD } \\
\text { (FT) }\end{array}$ & $\begin{array}{l}\text { WELLL } \\
\text { OEPTH } \\
\text { (FT) }\end{array}$ & $\begin{array}{c}\text { MAUOR } \\
\text { AQUIFER }\end{array}$ & $\begin{array}{l}\text { WATER } \\
\text { LEVEL } \\
\text { (FT) }\end{array}$ & $\begin{array}{l}\text { DATE } \\
\text { WATER } \\
\text { LEVEL } \\
\text { MEASURED }\end{array}$ & $\begin{array}{l}\text { YIELD } \\
\text { (GPM) }\end{array}$ & $\begin{array}{l}\text { DRAW } \\
\text { DOWN } \\
\text { (FT) }\end{array}$ & $\begin{array}{l}\text { LOG } \\
\text { AVAIL- } \\
\text { ABLE }\end{array}$ & $\begin{array}{c}\text { Decline, } \\
1971-73 \\
(\mathrm{ft})\end{array}$ & $\begin{array}{l}2 \text {-year } \\
\text { pumpage, } \\
1971-72 \\
(\text { acre-ft) }\end{array}$ \\
\hline $\begin{array}{l}\text { 10N1KEO1CO1 } \\
10 N 1 \text { GEOIDOI }\end{array}$ & $\begin{array}{l}462322 N 1204556.1 \\
462315 N 1204623.1\end{array}$ & $\begin{array}{l}\text { INEZ LEWIS } \\
\text { WRARNHART }\end{array}$ & ${ }_{H}^{H}$ & $\begin{array}{l}1035 \\
1050\end{array}$ & $\begin{array}{r}120 \\
82\end{array}$ & $\begin{array}{l}O A \\
O A\end{array}$ &.$^{7}$ & $5-72$ & 15 & 54 & $=$ & $=$ & $\because=$ \\
\hline $\begin{array}{l}10 N 1 G F 01 H O 1 \\
1\end{array}$ & $4 \curvearrowleft 2301 N 1204513.1$ & MATTEEW JAMES & H & 1006 & $\begin{array}{l}82 \\
54\end{array}$ & $\begin{array}{l}O_{0 A} A \\
O A\end{array}$ & 16 & --63 & $\begin{array}{r}8 \\
10\end{array}$ & $=$ & $=$ & $=$ & $=$ \\
\hline 10N1 GEOZNO1 & $462240 N 1204728.1$ & ALBEHT WATKINS & H & 1103 & 16 & $O_{A}$ & 12 & $4-58$ & $-{ }^{6}$ & -- & -- & -- & -- \\
\hline 10N1GF03NO1 & $462234 N 1204840.1$ & CLYDE RAMSEY & H & 1175 & 179 & $Y_{A}$ & 7 & $9-52$ & 5 & -- & -- & $-\cdot$ & -- \\
\hline $\begin{array}{l}\text { 10N16F05G01 } \\
10 N 16 E 09 \times 01\end{array}$ & $46225 \mathrm{HN} 1205046.1$ & HOGAN & I & 347 & $-\overline{367}$ & YA & 28 & $6-70$ & -- & -- & -- & 3 & 101 \\
\hline $\begin{array}{l}10 N 10 E 09 \times 01 \\
10 N 16 E 10 F 01\end{array}$ & $\begin{array}{l}462158 N 1204920.1 \\
462207 N 1204858.1\end{array}$ & $\begin{array}{l}\text { OSCAP THON } \\
\text { WR PACE }\end{array}$ & I & $\begin{array}{l}1245 \\
1220\end{array}$ & $\begin{array}{l}367 \\
112\end{array}$ & $\begin{array}{l}Y A \\
O A\end{array}$ & $\begin{array}{l}26 \\
10\end{array}$ & $\begin{array}{l}6-70 \\
4-58\end{array}$ & 150 & 130 & $=$ & $\begin{array}{r}4 \\
-2\end{array}$ & 42 \\
\hline $10 N 15 E 10 E 02$ & $462207 \mathrm{~N} 1204850 \cdot 1$ & $\begin{array}{l}\text { NA PACE } \\
\text { POY }\end{array}$ & ${ }^{H}$ & 1220 & 80 & $O A$ & 10 & -- & -- & -- & -- & $\ddot{z}$ & -. \\
\hline 10N1 GE 10J01 & $462157 N 1204744.1$ & RAY BPISHOIS & r & 1140 & 98 & $O A$ & -- & -- & 10 & -- & -- & -. & - \\
\hline 10N1KE 1 ONO1 & $462142 N 1204858.1$ & XH PACE JR & 1 & 1230 & 567 & rA & 33 & $1-53$ & 1300 & 94 & D & 6 & 394 \\
\hline 1ON1GE11CO1 & $\begin{array}{r}462230 N 1204707.1 \\
4650\end{array}$ & JAMES HLODGETT & H & 1080 & -- & $O A$ & 10 & $4-72$ & -- & -- & -- & $\because$ & $\because$ \\
\hline ION1KE $11 K 01$ & $462157 N 1204706.1$ & PHILIP AMRROSE & H & 1110 & 111 & $O A$ & 100 & -63 & 10 & -- & -- & $\because$ & $=$ \\
\hline $\begin{array}{l}\text { ION16E12H01 } \\
10 N 1 G E 12 L 01\end{array}$ & $\begin{array}{l}462214 N 1204513.1 \\
462204 N 1204601.1\end{array}$ & $\begin{array}{l}\text { A SHIPPENTONER } \\
\text { FHED COLFAX }\end{array}$ & ${ }_{H}^{H}$ & $\begin{array}{l}1050 \\
1060\end{array}$ & $\begin{array}{r}43 \\
115\end{array}$ & $\begin{array}{l}O A \\
O A\end{array}$ & $=$ & $=$ & $\begin{array}{l}10 \\
10\end{array}$ & $=$ & $=$ & $\cdots$ & $\overline{-}$ \\
\hline $10 N_{16 E} 15 \mathrm{MO} 1$ & $462100 N 1204856.1$ & LFONADD KUNEKI & $\mathrm{H}$ & 1290 & 125 & $Y_{A}$ & 67 & $4-72$ & 15 & -- & D & -- & -- \\
\hline 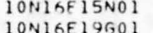 & $462053 N 1204857 \cdot 1$ & LFROY MCLAVEY & I & 1290 & 310 & YA & 65 & $2-55$ & 240 & 119 & -- & -. & 72 \\
\hline $\begin{array}{l}\text { I0N16E19G01 } \\
10 N 16 E 20 F 01\end{array}$ & $\begin{array}{l}46.025 N_{1205147.1} \\
462026 \mathrm{~N} 1205107.1\end{array}$ & $\begin{array}{l}\text { FORT SIMCOE JC } \\
\text { FORT SIMCOF }\end{array}$ & ${ }_{p}^{H}$ & $\begin{array}{l}1550 \\
1500\end{array}$ & $\begin{array}{l}425 \\
305\end{array}$ & $\begin{array}{r}Y A \\
Y A\end{array}$ & 26 & $\begin{array}{l}7-67 \\
6-70\end{array}$ & 60 & $\begin{array}{l}32 \\
80\end{array}$ & $D$ & $\cdots$ & 192 \\
\hline $\begin{array}{l}10 N 16 E 21001 \\
100\end{array}$ & $462041 N 1205008.1$ & FT SIMCOE ST PK & I & 1375 & $\begin{array}{l}305 \\
163\end{array}$ & $r_{A A}$ & -- & $\begin{array}{l}0-10 \\
--\end{array}$ & 340 & --8 & -- & +1 & 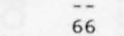 \\
\hline $\begin{array}{l}10 N 16 F 23 D_{01} \\
10 N 16 F 24 F 01\end{array}$ & $462036 N 1204725.1$ & CAROL LAWRENCE & H & 1180 & 131 & YA & - & -- & 10 & -- & 0 & $=$ & $=$ \\
\hline $\begin{array}{l}\text { ION1KE24FO1 } \\
10 N 17 E 02 F 01\end{array}$ & $\begin{array}{l}42024 N 1204558.1 \\
462303 N 1203938.1\end{array}$ & $\begin{array}{l}\text { WA CONST TH CTR } \\
\text { ROSEMARY MCKAY }\end{array}$ & ${ }_{H}^{H}$ & $\begin{array}{r}1160 \\
880\end{array}$ & $\begin{array}{l}216 \\
120\end{array}$ & $\begin{array}{r}Y A \\
O A\end{array}$ &.--88 & $\begin{array}{l}10-72 \\
--\end{array}$ & 60 & $=$ & $\begin{array}{l}D \\
D\end{array}$ & 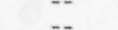 & 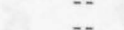 \\
\hline ION17F02M01 & $462256 N 1204004.1$ & LOUISE. JACKSON & $\vec{H}$ & 890 & $\begin{array}{r}120 \\
52\end{array}$ & $O_{O A}$ & -- & -- & $\begin{array}{l}10 \\
10\end{array}$ & $=$ & - & -- & $\cdots$ \\
\hline $10 N 17 E 03001$ & $462 ? 32 N 1204029.1$ & AMOS GRAIG & H & $\begin{array}{l}890 \\
900\end{array}$ & $-a^{52}$ & $\begin{array}{l}O A \\
O A\end{array}$ & 12 & $9-71$ & -- & - & - & - & - \\
\hline $\begin{array}{l}10 N 17 E 04 L 01 \\
10 N 17 F 04 N 01\end{array}$ & $462258 N 1204212.1$ & JOAN FRENCH & H & 940 & $\begin{array}{r}65 \\
55\end{array}$ & $0 \mathrm{~A}$ & $-\overline{34}$ & $\because \overline{5}$ & 10 & $=$ & 0 & $=$ & -. \\
\hline $\begin{array}{l}10 N 17 E 05 F .02 \\
102\end{array}$ & $462301 N 1204343.1$ & VAKIMA FIRE DI & $\mathrm{F}$ & 965 & $--^{55}$ & $\begin{array}{l}O A \\
O A\end{array}$ & -24 & $\begin{array}{l}5-71 \\
--2\end{array}$ & $=$ & $=$ & $=$ & $=$ & $\ldots$ \\
\hline $10 N 17 F 05 L 01$ & $462246 N 12104336.1$ & $\begin{array}{l}\text { OLIVER PIMMS } \\
\text { ROY }\end{array}$ & H & 980 & 142 & $O A$ & 26 & $5-72$ & 9 & 100 & D & .. & -- \\
\hline 10N17F05L02 & & & H & 980 & 59 & $O A$ & 18 & $5-72$ & 10 & 19 & D & $\cdots$ & -- \\
\hline $10 \times 17 F 05 L 03$ & $462249 \mathrm{~N} 1204330.1$ & KEITH CASSAOY & H & 980 & 91 & $O A$ & 18 & $9-72$ & 25 & 19 & 0 & -- & -- \\
\hline $\begin{array}{l}10 N 17 \\
10 N 17\end{array}$ & $\begin{array}{l}46225 \\
46224\end{array}$ & SALLIE LUC & H & 980 & 56 & $O A$ & 7 & $5-92$ & 14 & 14 & -- & $=$ & $\because$ \\
\hline $\begin{array}{l}10 \times 17 E 05 \times 01 \\
10 N 17 F 05 \times 02\end{array}$ & $\begin{array}{l}462240 N 1204350 \cdot 1 \\
462240 N 120349\end{array}$ & WWAN SCHOOL & $\mathrm{F}$ & 977 & 18 & $O A$ & 10 & $5-70$ & 500 & -- & -- & $\because$ & -- \\
\hline $\begin{array}{l}\text { l0N17F } 05 M 02 \\
10 N 17 E 05 M 03\end{array}$ & $\begin{array}{l}462244 N 1204349 \cdot 1 \\
462243 N 1204337: 1\end{array}$ & $\begin{array}{l}\text { W SWAN SCHOOL } \\
\text { N PACIFIC DWY }\end{array}$ & $\begin{array}{l}F \\
u\end{array}$ & $\begin{array}{l}977 \\
955\end{array}$ & $\begin{array}{r}18 \\
757\end{array}$ & $\begin{array}{l}O A \\
Y A\end{array}$ & $\begin{array}{r}9 \\
15\end{array}$ & $\begin{array}{c}5-70 \\
--\end{array}$ & 500 & $\ddot{z}$ & $\bar{D}$ & 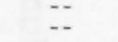 & $\ddot{z}$ \\
\hline 10N17EOSNO1 & $462241 N 1204351.1$ & ESMAN SCMOOL & $\mathrm{F}$ & 977 & 18 & $O A$ & 8 & $5-70$ & 500 & -- & -- & -- & -. \\
\hline $\begin{array}{l}\text { l0N17F05R01 } \\
10 N_{17 F 06 R 01}\end{array}$ & $\begin{array}{l}462535 N 1204313.1 \\
462313 N 1204426.1\end{array}$ & $\begin{array}{l}\text { YAKIMA TRIEE } \\
\text { LFONARD JAMES }\end{array}$ & ${ }_{H}^{\mathrm{H}}$ & $\begin{array}{l}973 \\
990\end{array}$ & $\begin{array}{l}84 \\
43\end{array}$ & ${ }_{0 A}^{O A}$ & 26 & $\begin{array}{l}11-57 \\
--\end{array}$ & $\begin{array}{l}25 \\
10\end{array}$ & $\ldots 0$ & $\therefore$ & $=$ & -- \\
\hline $10 N 17 F 06001$ & $462316 N 1204506.1$ & BOISE CASCAOF & H & 1000 & 242 & $E L$ & 32 & $7-70$ & 80 & -- & 0 & -. & -- \\
\hline $10 N 17 E 06702$ & $402315 N 1204505.1$ & BOISE CASCADE & N & 1000 & 12 & $O A$ & 5 & $6-70$ & -- & 1 & -- & -. & -. \\
\hline 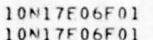 & $\begin{array}{l}462259 N 1204445.1 \\
462305 N 120440\end{array}$ & HENRY FIANDEP & H & 995 & 42 & $O A$ & 32 & -63 & 10 & $=$ & $-\overline{0}+x+3+a$ & - & $=$ \\
\hline $\begin{array}{l}10 N 17 F 06 F 0 ? \\
10\end{array}$ & $462305 N 1204446.1$ & $\begin{array}{l}\text { FPANCIS OLN } \\
\text { JOHN SWAN }\end{array}$ & H & 982 & 60 & $O_{A A}$ & 18 & -63 & $\begin{array}{l}10 \\
10\end{array}$ & -- & $\begin{array}{l}0 \\
0\end{array}$ & $=$ & $\because$ \\
\hline $10 N 17 F 06 F 03$ & $462306 \mathrm{~N} 1204444 \cdot 1$ & WM FI ANDER & $H$ & 995 & 42 & $O A$ & 19 & -63 & 10 & -- & -- & -- & -- \\
\hline $10 N 17 F 00504$ & $462304 \mathrm{~N} 1204430 \cdot 1$ & RUSS NATLAMET & H & 978 & 49 & OA & 30 & -63 & 10 & -- & D & - & $-\cdot$ \\
\hline 10N1 TE06GO & $120442 \mathrm{H} .1$ & 200Ts & H & 980 & - & $O A$ & 9 & $5-71$ & $\because$ & -- & -- & -- & -- \\
\hline $10 \mathrm{~N} 1$ & $4 \times 23$ & MIC & $H$ & $\begin{array}{l}980 \\
975\end{array}$ & 42 & $0 A$ & $-\overline{12}$ & 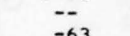 & 10 & $\because$ & -- & -- & -- \\
\hline 10N17E06G03 & $462304 \mathrm{~N} 1204427.1$ & CHARLES FI IANDER & H & 975 & 43 & $O A$ & 12 & -63 & 10 & 12 & -- & -. & -- \\
\hline $\begin{array}{l}10 N 17 F 066.04 \\
10 N 17 F 06 H_{01}\end{array}$ & $\begin{array}{l}462304 N 1204423.1 \\
46225 \times N 1204414.1\end{array}$ & $\begin{array}{l}\text { GEORGE ADAMS } \\
\text { ELMER OLHEY }\end{array}$ & ${ }_{H}^{H}$ & $\begin{array}{l}975 \\
980\end{array}$ & $\begin{array}{l}48 \\
94\end{array}$ & $\begin{array}{l}O A \\
O A\end{array}$ & 18 & -63 & $\begin{array}{l}10 \\
10\end{array}$ & $=$ & $\overline{0}$ & $=$ & $=$ \\
\hline 10N1 TE0SHOZ & $462258 N 1204357 \cdot 1$ & CECELIA ASHUE & H & 975 & 37 & $O A$ & -- & -- & 10 & -- & 0 & -- & -- \\
\hline $\begin{array}{l}10 N 17 E 07 \mathrm{AO} 1 \\
10 \mathrm{N17F07M01}\end{array}$ & $\begin{array}{l}4252000 N 1204420 \cdot 1 \\
462156 N 1204510.1\end{array}$ & $\begin{array}{l}\text { DELMAP OE } \\
\text { BILL ENE: }\end{array}$ & 4 & $\begin{array}{l}1010 \\
1170\end{array}$ & $\begin{array}{l}41 \\
51\end{array}$ & $\begin{array}{l}O A \\
O A\end{array}$ & $\ldots$ & -63 & 10 & $=$ & $=$ & - & $=$ \\
\hline $\begin{array}{l}\text { IONITE } 07 R 01 \\
\end{array}$ & $462140 N 1204355.1$ & JOHN SMAPTLONIT & 4 & 1030 & $\begin{array}{l}51 \\
65\end{array}$ & $O A$ & 24 & $4-72$ & 21 & 25 & 0 & - & - \\
\hline 10N17FOBLO1 & $462159 \times 1204455.1$ & AGNES COOTES & 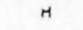 & 1000 & 42 & $O A$ & -- & $9-63$ & 10 & -- & -- & -- & -. \\
\hline
\end{tabular}




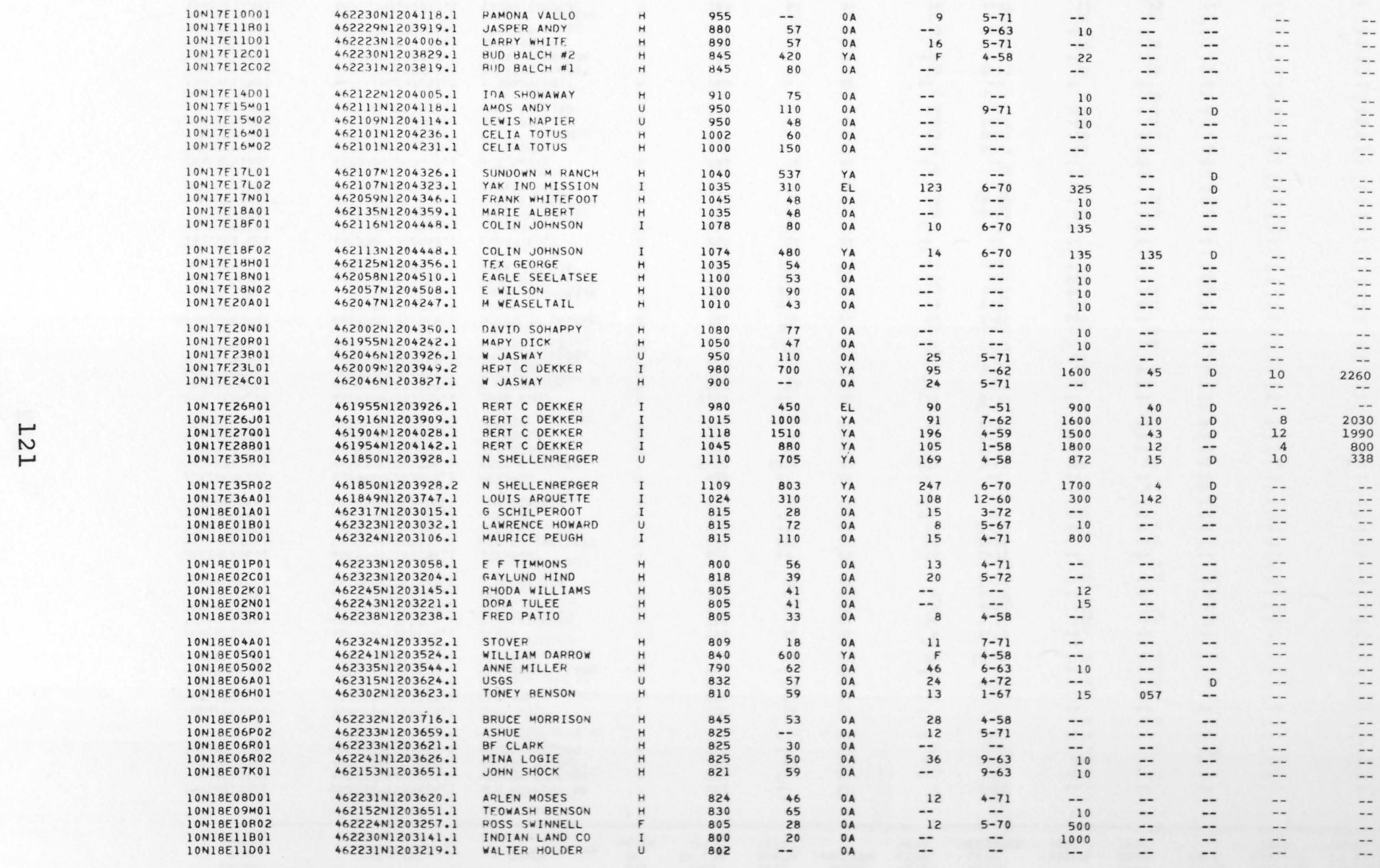


APPENDIX III.--Records of selected wells in the Toppenish Creek basin--Continued

\begin{tabular}{|c|c|c|c|c|c|c|c|c|c|c|c|c|c|}
\hline $\begin{array}{l}\text { LOCAL } \\
\text { NELLL } \\
\text { NUMBER }\end{array}$ & LAT-LONG & OWNER & $\begin{array}{l}\text { USE } \\
\text { OF } \\
\text { WATER }\end{array}$ & $\begin{array}{l}\text { ALTI - } \\
\text { TUDE- } \\
\text { OF LSD } \\
\text { (FT) }\end{array}$ & $\begin{array}{l}\text { WELLL } \\
\text { OEPTH } \\
\text { (FT) }\end{array}$ & $\begin{array}{c}\text { MAUOR } \\
\text { AQUIFER }\end{array}$ & $\begin{array}{l}\text { WATER } \\
\text { LEVEL } \\
\text { (FT) }\end{array}$ & $\begin{array}{l}\text { DATE } \\
\text { WATER } \\
\text { LEVEL } \\
\text { MEASURED }\end{array}$ & $\begin{array}{l}\text { YIELD } \\
\text { (GPM) }\end{array}$ & $\begin{array}{l}\text { DRAW } \\
\text { DOWN } \\
\text { (FT) }\end{array}$ & $\begin{array}{l}\text { LOG } \\
\text { AVAIL- } \\
\text { ABLE }\end{array}$ & $\begin{array}{l}\text { Decliner } \\
1971-73 \\
(\mathrm{ft})\end{array}$ & $\begin{array}{l}\text { 2-year } \\
\text { pumpage, } \\
1971-72 \\
\text { (acre-ft) }\end{array}$ \\
\hline ION1RE $12 A 01$ & $462229 \mathrm{~N} 1203016.1$ & WES MORFORI SR & H & 803 & -- & $O A$ & 7 & $7-71$ &.- & -- & -- & -- & -- \\
\hline $10 N 19 E 12 A 02$ & $462232 N 1203007.1$ & WESLEY MORF ORO & H & 800 & - & OA & -- & -- & $=$ & -- & $=$ & $=$ & $=$ \\
\hline 10N1BE12C01 & $462230 N 1203059.1$ & WILSON CHAPLEY & H & 800 & 67 & $O A$ & 10 & $5-67$ & 10 & -- & -- & -- & -. \\
\hline $\begin{array}{l}\text { 10N1 RE13801 } \\
\text { 1ON18F14J01 }\end{array}$ & $\begin{array}{l}462138 \mathrm{~N} 1203039.1 \\
462110 \mathrm{~N} 1203128.1\end{array}$ & $\begin{array}{l}\text { VELMA PHILIPS } \\
\text { JACK PICE }\end{array}$ & $\underset{H}{H}$ & $\begin{array}{l}790 \\
785\end{array}$ & $=$ & $\begin{array}{l}O A \\
O A\end{array}$ & $-{ }^{1}$ & $=$ & $\because$ & $=$ & $=$ & $=$ & $=$ \\
\hline ION1BE.14J02 & $462102 N 1203128.1$ & JACK RICE & 1 & 785 & 14 & $O A$ & -- & -- & -- & -- & -- & .. &.- \\
\hline 10N18E15L01 & $462103 N 1203323.1$ & AL CAPL & H & 800 & 54 & $O A$ & -- & -- & 15 & -- & -- & -- & - \\
\hline ION1BE18AOI & $\begin{array}{l}462140 N 1203622.1 \\
4\end{array}$ & $\begin{array}{l}\text { USGS } \\
\text { RUP SPORTS EISH }\end{array}$ & $u$ & 820 & 62 & $O A$ & 5 & $4-72$ & -- & -- & $D$ & -- & -- \\
\hline $\begin{array}{l}\text { 10N1BE19J01 } \\
10 N 1 B E 21001\end{array}$ & $\begin{array}{l}462016 N 1203630.1 \\
462046 N 1203458.1\end{array}$ & $\begin{array}{l}\text { BUR SPORTS FISH } \\
\text { LW HEALY }\end{array}$ & u & $\begin{array}{l}840 \\
820\end{array}$ & $\overline{63}$ & $\begin{array}{l}O A \\
O A\end{array}$ & $\overline{28}$ & $11 \overline{-71}$ & $=$ & $=$ & $=$ & $=$ & -- \\
\hline 10N1 AE23A01 & $462046 N 1203136.1$ & OI NEY & $\mathrm{H}$ & 790 & 41 & $O A$ & 9 & $5-71$ & -- & -- & -- & -- & -- \\
\hline $10 N 1$ AE $23 F 01$ & $462032 N 1203214.1$ & O SOCKZEHIGH & $\mathrm{H}$ & 788 & 42 & $O A$ & 16 & $9-71$ & 12 & - & 0 & -- & -- \\
\hline 10N1AE 24401 & $462045 N 1203012.1$ & MARIE NOLF & H & 778 & 63 & $O A$ & 8 & $2-67$ & 10 & 17 & D & -- & -- \\
\hline $\begin{array}{l}\text { 10N18E25001 } \\
10 N 1 \text { QE26DO1 }\end{array}$ & $\begin{array}{l}461954 N 1203161.1 \\
461952 N 1203227.1\end{array}$ & $\begin{array}{l}\text { USGS } \\
\text { R GOLOSMITH }\end{array}$ & $\begin{array}{c}u \\
H\end{array}$ & $\begin{array}{l}786 \\
790\end{array}$ & $\begin{array}{l}62 \\
80\end{array}$ & $\begin{array}{l}O A \\
O A\end{array}$ & 8 & $\begin{array}{l}4-72 \\
5-71\end{array}$ & -- & $\because-$ & 0 & $z$ & $=$ \\
\hline 10N1 RE 26001 & $461904 \mathrm{~N} 1203138.1$ & UNKNOWN & $\mathrm{H}$ & 825 & -- & $O A$ & 15 & $5-71$ & $\ldots$ & -- & -- & -- & -- \\
\hline $10 N 1 B E 27 \mathrm{NOO}$ & $461906 N 1203311.1$ & WAPATI IRR DIST & H & 820 & 180 & $O A$ & $\begin{array}{l}15 \\
25\end{array}$ & $5-71$ & - & - & - & $=$ & $=$ \\
\hline 10N1BE28R01 & $461904 N 1203350.1$ & IJNKNOWN & $u$ & 845 & -- & $O A$ & 17 & $5-71$ & -- & -- & -- & -- & -- \\
\hline $\begin{array}{l}\text { 10N18F29MO1 } \\
\text { ION1BE29NO1 }\end{array}$ & $\begin{array}{l}461927 \mathrm{~N} 1203609.1 \\
461904 \mathrm{~N} 1203608.1\end{array}$ & $\begin{array}{l}\text { UNKNOWN } \\
\text { FRAND SKEELS }\end{array}$ & ${ }_{H}^{H}$ & $\begin{array}{l}855 \\
902\end{array}$ & $-\overline{65}$ & $\begin{array}{l}O A \\
O A\end{array}$ & $=$ & $=$ & $=$ & $=$ & $=$ & -- & $\begin{array}{l}-- \\
--\end{array}$ \\
\hline 10N1 BE 30001 & $461904 \mathrm{~N} 1203650.1$ & UNKNOWN & $u$ & 922 & -- & $O A$ & -- & -- & -. & -- & -- & -- & -- \\
\hline ION1BE31NO1 & $461823 N 1203734.1$ & BERT C DEKKEO & I & 1138 & 1044 & YA & 233 & $8-63$ & 388 & 53 & -- & 7 & 107 \\
\hline $\begin{array}{l}10 N 18 E 32 A 01 \\
10 N 18 E 32 C 01\end{array}$ & $\begin{array}{l}4661902 N 1203506.1 \\
461901 N 1203544.1\end{array}$ & $\begin{array}{l}\text { JIM COSNER } \\
\text { UNKNOWN }\end{array}$ & ${ }_{u}^{H}$ & $\begin{array}{l}860 \\
900\end{array}$ & $\begin{array}{l}90 \\
80\end{array}$ & $\begin{array}{l}O A \\
O A\end{array}$ & $\begin{array}{l}16 \\
33\end{array}$ & $\begin{array}{l}5-71 \\
5-71\end{array}$ & $=$ & $=$ & $=$ & $=$ & $=$ \\
\hline $10 N 1 B E 34 A 01$ & $461901 \mathrm{~N} 1203251.1$ & UNKNOWN & u & 841 & -- & $O A$ & $\begin{array}{l}35 \\
34\end{array}$ & $\begin{array}{l}5-11 \\
6-71\end{array}$ & $=$ & $=$ & $=$ & - & - \\
\hline $10 N 18 E 34 L 01$ & $461834 N 1203312.1$ & JOHN CARL & H & 1090 & - & $O A$ & 117 & $5-71$ & -- & -- & -- & -- & -- \\
\hline $\begin{array}{l}10 N 18 E 36001 \\
10 N 19 E 01 C 01\end{array}$ & $461902 N 1203107.1$ & F WEGMILLER & H & 862 & 93 & OA & & $6-67$ & 10 & -- & -- & -- & -- \\
\hline $\begin{array}{l}\text { 10N19E01CO1 } \\
\text { ION19EO1E01 }\end{array}$ & $\begin{array}{l}462323231202307.1 \\
4623258 N 1202342.1\end{array}$ & $\begin{array}{l}\text { LOTTIE WHITE } \\
\text { ANDREW }\end{array}$ & H & 790 & $\begin{array}{l}64 \\
63\end{array}$ & OA & 14 & $\begin{array}{l}1-67 \\
1-67\end{array}$ & 10 & 008 & $D$ & -- & -- \\
\hline $\begin{array}{l}\text { 10N9EOIEOI } \\
\text { IONIGEOIMOI }\end{array}$ & $\begin{array}{l}46258 \mathrm{~N} 1202342.1 \\
462245 \mathrm{~N} 1202343.1\end{array}$ & $\begin{array}{l}\text { ANDREW LILLIE } \\
\text { ANDREW LILY }\end{array}$ & ${ }_{H}^{H}$ & $\begin{array}{l}790 \\
788\end{array}$ & $\begin{array}{l}63 \\
58\end{array}$ & $\begin{array}{l}O A \\
O A\end{array}$ & $\begin{array}{l}13 \\
14\end{array}$ & $\begin{array}{l}1-67 \\
2-67\end{array}$ & $\begin{array}{l}10 \\
10\end{array}$ & --5 & $\begin{array}{l}D \\
D\end{array}$ & -- & $\overline{-}$ \\
\hline $10 N 19 E 01 N 01$ & $462232 N 1202343.1$ & MCKINLEY GRANGE & H & 786 & 24 & $O A$ & 13 & $1-59$ & 500 & -- & -- & -- & .. \\
\hline ION19EOIPOI & & GOMACHE & H & 781 & $\because$ & $O A$ & 10 & $6-70$ & 10 & -- & -- & -- & -- \\
\hline 10N19E02P01 & $462233 \mathrm{N1202427.1}$ & ERNIE CHAMPEAUX & H & 790 & 60 & $O A$ & -- & -- & 500 & $\ddot{z}+$ & $\cdots$ & $\ldots$ & $\overline{-}$ \\
\hline $\begin{array}{l}\text { ION19E02P02 } \\
\text { ION19E03E01 }\end{array}$ & $\begin{array}{l}462234 \mathrm{~N} 1202424.1 \\
46230 \mathrm{BN} 1202613.1\end{array}$ & $\begin{array}{l}\text { FIRE OISTRICT } 5 \\
\text { TOSH UMEMOTO }\end{array}$ & ${ }_{H}^{F}$ & $\begin{array}{l}790 \\
805\end{array}$ & $\begin{array}{l}22 \\
60\end{array}$ & $\begin{array}{l}O A \\
O A\end{array}$ & $-{ }_{-13}$ & $=$ & 500 & $\ddot{z}$ & 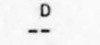 & $=$ & $\overline{-}$ \\
\hline $10 N 19 E 07801$ & $462230 N 1202908.1$ & LARRY COLE & H & 801 & 60 & $O A$ & -- & $=$ & -- & -- & -- & -- & -- \\
\hline iON & 4622 & JOE & H & 80 & 60 & $O A$ & 10 & $4-71$ & -- & -- & -- & -- & - \\
\hline 10N19EOTRO1 & $462140 N 1202858.1$ & RODRICK DAVIS & H & 790 & 61 & $O A$ & 15 & $3-67$ & 10 & -- & -- & -- & -- \\
\hline $\begin{array}{l}\text { 10N19E08NO1 } \\
\text { ION19EOBNOZ }\end{array}$ & $\begin{array}{l}462140 \mathrm{~N} 1202836.1 \\
462140 \mathrm{~N} 1202846.1\end{array}$ & $\begin{array}{l}\text { SHIRLEY MANZANO } \\
\text { HARVEY DAVIS }\end{array}$ & $\underset{H}{H}$ & $\begin{array}{l}790 \\
792\end{array}$ & $\begin{array}{l}62 \\
64\end{array}$ & $\begin{array}{l}O A \\
O A\end{array}$ & $\begin{array}{l}12 \\
14\end{array}$ & $\begin{array}{l}4-10 \\
5-67\end{array}$ & $\overline{10}$ & $=$ & $=$ & $=$ & $=$ \\
\hline 1ON19E11BO1 & $462232 N 1202418.1$ & "t t sauve & H & 790 & 38 & $O A$ & -- & -- & -- & -- & -- & .- & -. \\
\hline $10 N 19$ & 46 & $\mathrm{RCO}$ & H & 78 & 67 & $O A$ & 7 & $6-67$ & 10 & -- & 0 & -- & -- \\
\hline 10N19E11P01 & $462142 N 1202439.1$ & DAVIO MILLER & H & 775 & 69 & $O A$ & 13 & $3-67$ & 10 & -- & -- & -- & $\cdots$ \\
\hline $\begin{array}{l}\text { 10N19E12401 } \\
\text { 1ON19E12001 }\end{array}$ & $\begin{array}{l}462204 \mathrm{~N} 1202342.1 \\
462142 \mathrm{~N} 1202304: 1\end{array}$ & $\begin{array}{l}\text { TEO JOE } \\
\text { MOSE WINNIER }\end{array}$ & ${ }_{H}^{H}$ & $\begin{array}{l}781 \\
775\end{array}$ & $\begin{array}{l}60 \\
64\end{array}$ & $\begin{array}{l}O A \\
O A\end{array}$ & $\begin{array}{l}13 \\
12\end{array}$ & $\begin{array}{l}1-67 \\
2-67\end{array}$ & $\begin{array}{l}10 \\
10\end{array}$ & $\begin{array}{l}6 \\
7\end{array}$ & $\overline{0}$ & $=$ & $=$ \\
\hline $10 N 19 E 12 R 01$ & $462141 \mathrm{~N} 1202231.1$ & K SMARTLOWIT & H & 765 & -- & $O A$ & -- & -- & -- & -- & -- & -- & -- \\
\hline $\begin{array}{l}\text { 10N19E12R02 } \\
\text { ON19E14A01 }\end{array}$ & $\begin{array}{l}462141 \mathrm{~N} 1202229 \cdot 1 \\
462138 N 1202347.1\end{array}$ & $\begin{array}{l}\text { CHESTER WAHAAT } \\
\text { OTTO HALERSON }\end{array}$ & ${ }_{H}^{H}$ & $\begin{array}{l}767 \\
776\end{array}$ & $-{ }_{-61}$ & $\begin{array}{l}O A \\
O A\end{array}$ & --10 & $\begin{array}{l}2-67 \\
--\end{array}$ & $-{ }_{-10}^{10}$ & -216 & $=$ & $=$ & $=$ \\
\hline $\begin{array}{l}10 N 19 E 14 C 01 \\
19\end{array}$ & $462137 N 1202424.1$ & ALEX HESLEY & $\mathrm{H}$ & 777 & 71 & $O A$ & 14 & $2-67$ & 10 & 8 & $=$ & -- & - \\
\hline $10 N 19 F 14 K 01$ & $462107 N 1202406.1$ & TOM ELY & $\mathrm{H}$ & 768 & 69 & $O A$ & 9 & $4-71$ & -- & & -- & -- & - \\
\hline 1ON19E16A01 & $462137 N 1202617.1$ & $\begin{array}{l}\text { LAURA CORPUS } \\
\text { LEUPAS }\end{array}$ & H & 784 & 60 & $O A$ & 16 & $4-67$ & 10 & 15 & -- & -- & $\cdots$ \\
\hline $\begin{array}{l}\text { 10N19E16D01 } \\
\text { 10N19E16J01 }\end{array}$ & & $\begin{array}{l}\text { FELIX RABANAL } \\
\text { ROLAND BRULOTTE }\end{array}$ & $\stackrel{H}{F}$ & $\begin{array}{l}7855 \\
780\end{array}$ & $\begin{array}{l}61 \\
34\end{array}$ & $\begin{array}{l}{ }_{0 A}^{O A} \\
O A\end{array}$ & -7 & $5-70$ & $\begin{array}{l}10 \\
500\end{array}$ & $z$ & $\therefore$ & $\overline{-}$ & $\bar{x}$ \\
\hline $10 N 19917701$ & $\begin{array}{l}462114 N 1202734.1 \\
462105 N 1202834.1\end{array}$ & $\begin{array}{l}\text { MARIE OLNEY } \\
\text { MAURIE PEUGH }\end{array}$ & ${ }_{1}^{H}$ & $\begin{array}{l}783 \\
782\end{array}$ & $\begin{array}{l}75 \\
20\end{array}$ & ${ }_{0 \mathrm{~A}}^{O A}$ & 20 & $4-67$ & 11 & 10 & 0 & - & 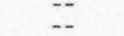 \\
\hline & & & & & & & & & & & & -- & \\
\hline
\end{tabular}




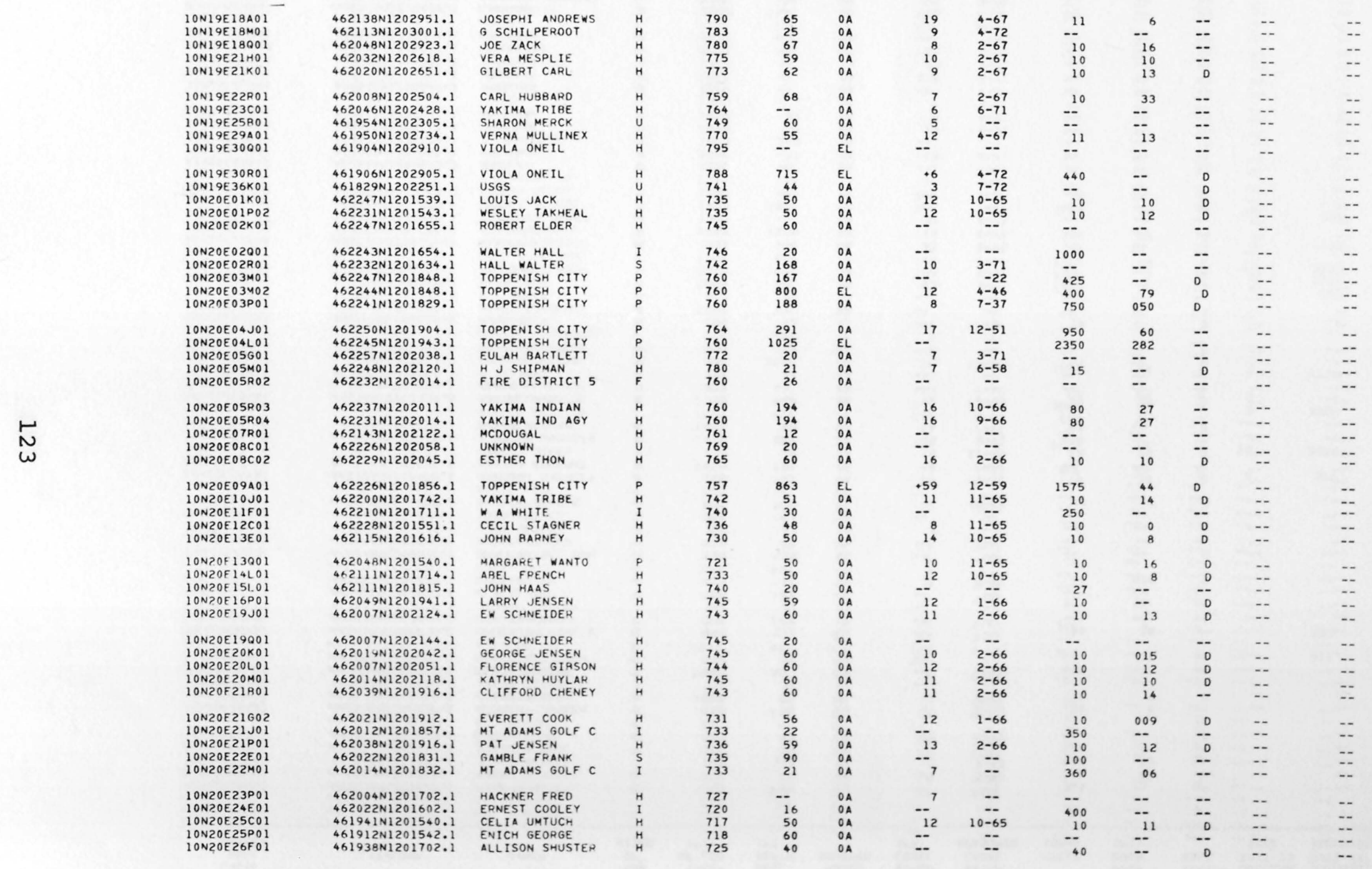


APPENDIX III.--Records of selected wells in the Toppenish Creek basin--Continued

\begin{tabular}{|c|c|c|c|c|c|c|c|c|c|c|c|c|c|}
\hline $\begin{array}{l}\text { LOCAL } \\
\text { NELLL } \\
\text { NUMAER }\end{array}$ & LAT-LONG & OWNER & $\begin{array}{c}\text { USE } \\
\text { OF } \\
\text { WATER }\end{array}$ & $\begin{array}{l}\text { ALTI- } \\
\text { TUDE- } \\
\text { OF LSD } \\
\text { (FT) }\end{array}$ & $\begin{array}{l}\text { MELL } \\
\text { DEPTH } \\
\text { (FT) }\end{array}$ & $\begin{array}{l}\text { MA JOR } \\
\text { AQUIFER }\end{array}$ & $\begin{array}{l}\text { WATER } \\
\text { LEVEL } \\
\text { (FT) }\end{array}$ & $\begin{array}{l}\text { DATE } \\
\text { WATER } \\
\text { LEVEL } \\
\text { MEASURED }\end{array}$ & $\begin{array}{l}\text { YIELD } \\
\text { (GPM) }\end{array}$ & $\begin{array}{l}\text { DRAW } \\
\text { DOWN } \\
\text { (FT) }\end{array}$ & $\begin{array}{l}\text { LOG } \\
\text { AVAIL- } \\
\text { ABLEE }\end{array}$ & $\begin{array}{c}\text { Decline, } \\
1971-73 \\
(\mathrm{ft})\end{array}$ & $\begin{array}{l}\text { 2-year } \\
\text { pumpage, } \\
1971-72 \\
\text { (acre-ft) }\end{array}$ \\
\hline 10N20F.26HOI & $461938 N 1201628.1$ & FILBUR BASEY & I & 723 & 25 & $O A$ & -- & -. & 300 & -- & -- & -- & -- \\
\hline $\begin{array}{l}10 N 20 E 27 A 01 \\
10 N 20 E 2701\end{array}$ & $\begin{array}{l}461953 N 1201751.1 \\
461945 N 1201803\end{array}$ & $\begin{array}{l}\text { FPANK GAMBLE } \\
\text { FRANK GMIE }\end{array}$ & I & 730 & 75 & OA & 1 & $3-62$ & 310 & 46 & -- & -- & - \\
\hline $\begin{array}{l}10 N 20 E 27801 \\
10 N 20 F 28 F 01\end{array}$ & $\begin{array}{l}461945 N 1201803.1 \\
461941 N 1201944.1\end{array}$ & $\begin{array}{l}\text { FRANK GAMBLE } \\
\text { DELBERT CARL }\end{array}$ & I & $\begin{array}{l}725 \\
734\end{array}$ & $\begin{array}{l}110 \\
36\end{array}$ & OA & ${ }^{2}$ & $\begin{array}{l}7-52 \\
---\end{array}$ & 600 & 10 & -- & -- & -. \\
\hline $10 N 20 E 28 R 01$ & $\begin{array}{l}461941 N 1201944.1 \\
461905 N 1201850.1\end{array}$ & $\begin{array}{l}\text { OELAERT CARL } \\
\text { USGS }\end{array}$ & u & $\begin{array}{l}734 \\
725\end{array}$ & $\begin{array}{l}36 \\
43\end{array}$ & $\begin{array}{l}\text { OA } \\
O A A\end{array}$ & $\begin{array}{r}7 \\
12\end{array}$ & $4-72$ & 420 & $--^{4}$ & $\overline{0}$ & 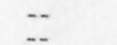 & 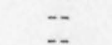 \\
\hline 10N20E29G01 & $461930 N 1202037.1$ & STANLEY JENSEN & $h$ & 738 & 65 & $O A$ & 10 & $2-66$ & 10 & 8 & -- & -- & -- \\
\hline $\begin{array}{l}10 N 20 E 29901 \\
10 N 20 E 29 N 01\end{array}$ & $\begin{array}{l}461938 \times 1202012.1 \\
461911 N 1202120.1\end{array}$ & $\begin{array}{l}\text { OELBERT CARL } \\
\text { CELIA TOTUS }\end{array}$ & $\vec{I}$ & $\begin{array}{l}736 \\
736\end{array}$ & $\begin{array}{l}65 \\
35\end{array}$ & $\begin{array}{l}O A \\
O A\end{array}$ & 11 & $\begin{array}{l}2-66 \\
--\end{array}$ & 10 & 8 & D & - & - \\
\hline $10 N 20 E 30 L 01$ & $461926 \mathrm{~N} 1202211.1$ & JULIA DRURY & I & 741 & -- & $\begin{array}{l}\text { OA } \\
O A\end{array}$ & -- & $4-68$ & 400 & $=$ & $z$ & 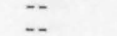 & -- \\
\hline 10N20E32K01 & $461827 N 1202023.1$ & BUR SPORT FISH & H & 740 & 80 & $O A$ & -- & -- & -- & 12 & -- & - & $=$ \\
\hline $\begin{array}{l}10 N 20 E 32 K 02 \\
10 N 20 E 32401\end{array}$ & $\begin{array}{l}461825 \mathrm{~N} 1202033.1 \\
461825 \mathrm{~N} 1202104.1\end{array}$ & $\begin{array}{l}\text { INTERIOR FSWL S } \\
\text { ART GAOLEY }\end{array}$ & $\begin{array}{l}\mathrm{I} \\
\mathrm{I}\end{array}$ & $\begin{array}{l}740 \\
739\end{array}$ & $\begin{array}{r}110 \\
18\end{array}$ & $\begin{array}{l}O A \\
O A\end{array}$ & $=$ & $=$ & 50 & 15 & $=$ & -- & -- \\
\hline $10 N 20 E 32001$ & $461821 \mathrm{N1202036.1}$ & ARTHUR GADLEY & I & 742 & 22 & $O A$ & - & - & $=$ & $=$ & $=$ & 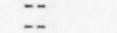 & $=$ \\
\hline $10 N 20 E 33 L 01$ & $451830 N 1201930.1$ & OE CLYOE & H & 745 & 40 & OA & -- & - & $=$ & $=$ & $=$ & 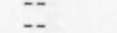 & -- \\
\hline $10 N 20 E 34 F 01$ & $461843 \mathrm{~N} 1201827.1$ & JOHNNY JIM & H & 735 & 41 & $O A$ & 11 & $9-63$ & 40 & 009 & D & - & $z$ \\
\hline $\begin{array}{l}1 \text { ON2OE 35F } 01 \\
1 \text { ON2OE 36BO1 }\end{array}$ & $\begin{array}{l}461846 \mathrm{~N} 1201657.1 \\
461848 \mathrm{~N} 1201530.1\end{array}$ & $\begin{array}{l}\text { BENT BARRELL GUN } \\
\text { MARY SETTLER }\end{array}$ & $\underset{H}{H}$ & $\begin{array}{l}718 \\
718\end{array}$ & $\begin{array}{r}120 \\
40\end{array}$ & $\begin{array}{l}O A \\
O A\end{array}$ & -- & $=$ & $=$ & $=$ & $\therefore$ & $\because$ & $z$ \\
\hline $10 N 20 E 36 G 01$ & $461846 N 1201537.1$ & MARY UMTUCH & H & 718 & 40 & $O A$ & 3 & - & -- & $=$ & $\overline{0}$ & -- & -- \\
\hline $\begin{array}{l}10 N 20 E 36 G 02 \\
10 N 21607001\end{array}$ & $\begin{array}{l}461847 N 1201538.1 \\
4\end{array}$ & MARY UMTUCH & H & 718 & 50 & $O A$ & -- & - & -- & -- & -- & -- & $=$ \\
\hline 10N21E07D01 & $462229 \mathrm{~N} 1201500.1$ & KELLEY GEORGE & ${ }^{\mathrm{H}}$ & 728 & 50 & OA & 11 & $10-65$ & 10 & 10 & D & -- & -- \\
\hline $\begin{array}{l}10 N 21 E 07 \times 01 \\
10 N 21501\end{array}$ & $\begin{array}{l}462203 N 1201423.1 \\
462142 N 120146.1\end{array}$ & $\begin{array}{l}\text { VIRGINI SHIRLEY } \\
\text { YAKIMA }\end{array}$ & $\begin{array}{c}H \\
u\end{array}$ & $\begin{array}{l}723 \\
715\end{array}$ & 61 & $\begin{array}{l}0 A \\
0 A\end{array}$ & 7 & $6-71$ & 10 & 10 & D & $=$ & $=$ \\
\hline $\begin{array}{l}\text { ION21E17701 } \\
\text { ION21F19P01 }\end{array}$ & $461954 \mathrm{~N} 1201436.1$ & $\begin{array}{l}\text { YAKIMA IND NAT } \\
\text { ERNEST JAMES }\end{array}$ & $u^{4}$ & $\begin{array}{l}715 \\
710\end{array}$ & $\begin{array}{l}21 \\
48\end{array}$ & $\begin{array}{l}O_{0 A} \\
0 A\end{array}$ & 14 & $11-65$ & 10 & 10 & $\overline{0}$ & - & $\bar{z}$ \\
\hline $\begin{array}{l}10 N 21 F 21 \mathrm{~F} 01 \\
1001\end{array}$ & $462019 N 1201118.1$ & $\begin{array}{l}\text { CITY OF GRANGEE } \\
\text { CITY GR }\end{array}$ & ${ }_{p}^{H}$ & $\begin{array}{l}710 \\
735\end{array}$ & 207 & $O A$ & 28 & $3-71$ & 400 & -- & -- & -. & $\overline{-}$ \\
\hline IONZIEZBLOI & $461917 N 1201156.1$ & SILAS PETERS & H & 704 & 42 & $O A$ & 4 & -- & 40 & -- & D & - & 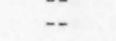 \\
\hline 10N21E29B01 & $461944 N 1201310.1$ & SIMON JOHN & H & 710 & 60 & $O A$ & 12 & $2-65$ & 10 & 10 & D & -- & -- \\
\hline $\begin{array}{l}10 N 21 E 29 F 01 \\
10 N 2133201\end{array}$ & $\begin{array}{l}461942 N 1201326.1 \\
466851 N 1201258.1\end{array}$ & $\begin{array}{l}\text { UNKNOWN } \\
\text { C BEAVERT }\end{array}$ & $u_{4}^{u}$ & $\begin{array}{l}710 \\
704\end{array}$ & $-\overline{24}$ & $\begin{array}{l}0 A \\
0 A\end{array}$ & $=$ & $=$ & -- & $=$ & $\ddot{z}$ & -- & -- \\
\hline $\begin{array}{l}10 N 21 E 32801 \\
10 N 21 F 33801\end{array}$ & $\begin{array}{l}4661851 N 1201258.1 \\
461859 N 1201148.1\end{array}$ & LFNA PHILLIPS & $\mathrm{H}$ & $\begin{array}{l}704 \\
701\end{array}$ & $\begin{array}{l}24 \\
41\end{array}$ & $\begin{array}{l}\text { OA } \\
0 A\end{array}$ & 3 & - & 60 & - & D & $z$ & z- \\
\hline $10 \mathrm{N21E} 33 \mathrm{CO} 1$ & $461855 \mathrm{~N} 1201155.1$ & LENA SOHAPPY & H & 703 & 42 & $O A$ & 5 & -- & -- & -- & D & -- & - \\
\hline $\begin{array}{l}10 N 21 E 34001 \\
10 N 21 E 34601\end{array}$ & $\begin{array}{l}461903 N 1201114.1 \\
461840 N 1201030 .\end{array}$ & $\begin{array}{l}\text { MOSE DICK } \\
\text { JAMES STRONG }\end{array}$ & ${ }_{H}^{H}$ & $\begin{array}{l}700 \\
691\end{array}$ & 42 & $O A$ & $=$ & $=$ & 10 & -- & D & -- & 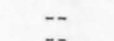 \\
\hline $\begin{array}{l}10 N 21 E 34601 \\
10 N 21 E 35 C 01 \\
10561\end{array}$ & $461855 N 1200936.1$ & $\begin{array}{l}\text { JAMES STRONG } \\
\text { B L WORNELL }\end{array}$ & u & $\begin{array}{l}691 \\
682\end{array}$ & 16 & $\begin{array}{l}O_{0 A}^{A} \\
0 A\end{array}$ & $\bar{z}$ & $\bar{z}+$ & $=$ & $\bar{z}$ & $=$ & $z$ & $=$ \\
\hline $11 N 16508 K 01$ & $462709 \mathrm{~N} 1205046.1$ & UNKNOWN & u & 1550 & $=$ & $O A$ & 12 & $4-71$ & - & - & - & -- & - \\
\hline 11N16E09L01 & $462715 N 12.04954 .1$ & UNKNOWN & H & 1510 & 76 & OA & 32 & $4-71$ & -- & -- & -- & - & -- \\
\hline $\begin{array}{l}\text { 11N16E11P01 } \\
11 \mathrm{~N} 16 E 14 \mathrm{CO} 1\end{array}$ & $\begin{array}{l}462702 N 1204726.1 \\
462651 N 1204716.1\end{array}$ & $\begin{array}{l}\text { UNKNOWN } \\
\text { NORTHOVER }\end{array}$ & $\underset{H}{H}$ & $\begin{array}{l}1301 \\
1280\end{array}$ & $\overline{100}$ & $\begin{array}{l}O A \\
O A\end{array}$ & $\begin{array}{l}41 \\
19\end{array}$ & $\begin{array}{l}4-71 \\
4-71\end{array}$ & $=$ & $=$ & $=$ & z- & z- \\
\hline IINIGE $15 A 01$ & $462651 \mathrm{~N} 1204804.1$ & FLORENCE OLNEY & H & 1320 & -- & $O A$ & 32 & $4-71$ & -- & -- & -- & -- & -- \\
\hline 11N16E15K01 & $462614 \mathrm{~N} 1204803.1$ & $\begin{array}{l}\text { USGS } \\
\text { uSGS }\end{array}$ & $u$ & 1285 & $z$ & EL & -- & $=-$ & -- & -- & 32 & - & -- \\
\hline $11 N 16 F 15 \times 02$ & $462614 \mathrm{~N} 1204803.2$ & USGS & u & 1285 & - & EL & -- & -- & - & -- & 32 & -- & -- \\
\hline $\begin{array}{l}\text { 11N16E15K03 } \\
11 N 16 E 16 P 01\end{array}$ & $\begin{array}{l}462614 \mathrm{~N} 1204803.3 \\
462608 \mathrm{~N} 1204950.1\end{array}$ & $\begin{array}{l}\text { USGS } \\
\text { UNKNOWN }\end{array}$ & $\begin{array}{l}u \\
H\end{array}$ & $\begin{array}{l}1285 \\
1390\end{array}$ & $-\overline{35}$ & $\begin{array}{l}E L \\
O A\end{array}$ & $\overline{13}$ & $\ddot{4=71}$ & $=$ & $=$ & 32 & $=$ & z- \\
\hline IINIGE ITEOI & $462637 \mathrm{~N} 1205120.1$ & $c$ o & H & 1530 & 142 & YA & $\because 0$ & -- & -- & -- & D & -- & -- \\
\hline 11N16E17N01 & $462601 N 1205111.1$ & UNKNOWN & H & 1478 & $\begin{array}{r}45 \\
85\end{array}$ & OA & 19 & $4-71$ & -- & -- & -- & -- & -- \\
\hline 11N16E.20F 01 & $462546 \mathrm{~N} 1205101.1$ & UNKNOWN & H & 1422 & 85 & OA & 9 & $4-71$ & -- & -- & -- & -- & -- \\
\hline $\begin{array}{l}\text { I1N16E20001 } \\
\text { IINIGE2INO1 }\end{array}$ & $462518 N 1205040.1$ & UNKI & H & 1370 & -- & OA & -- & --7 & -- & -- & -- & -- & -- \\
\hline & $\begin{array}{l}462524 \mathrm{~N} \\
462521 \mathrm{~N}\end{array}$ & UN & $H_{H}^{H}$ & 13 & $z$ & OA & 18 & $\begin{array}{l}4-71 \\
4071\end{array}$ & -- & -- & -- & $=$ & $=$ \\
\hline 11N16E21OC & $462521 \mathrm{~N} 1204920.1$ & UNKNOWN & H & 1318 & -- & $O A$ & 23 & $4-71$ & -- & -- & -- & -- & -- \\
\hline $\begin{array}{l}\text { INN16E21002 } \\
11 N 16 E 2 Z R B 1\end{array}$ & $\begin{array}{l}462516 N 1204927.1 \\
462543 N 1204808.1\end{array}$ & $\begin{array}{l}\text { UNKNOWN } \\
\text { UNKNOWN }\end{array}$ & ${ }_{H}^{H}$ & $\begin{array}{l}1318 \\
1262\end{array}$ & $\because$ & $\begin{array}{l}O_{A} A \\
0 A\end{array}$ & 26 & $\begin{array}{l}4-71 \\
--\end{array}$ & $=$ & 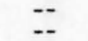 & -- & $z$ & $\bar{z}$ \\
\hline 11N16E2ZG & $462539 N 1204812.1$ & UNKNO & $\mathrm{H}$ & 12 & -- & OA & 10 & -- & -- & -- & -- & -- & -- \\
\hline 11N16E22 & $\begin{array}{l}462534 N 12048 \\
462551 N 12046\end{array}$ & LFONARD ARQUETT & H & 13 & $z$ & $O A$ & 27 & $\begin{array}{l}4-7 \\
4-7\end{array}-7-30$ & -- & -- & -- & -- & -- \\
\hline $\begin{array}{l}11 N 16 E 23 E \\
1 N 16 E 256\end{array}$ & $\begin{array}{l}462551 N 1204 \\
4624461204\end{array}$ & $\begin{array}{l}\text { UNKNOWN } \\
\text { RIL RLOD }\end{array}$ & u & 11 & 525 & $O A$ & $\begin{array}{r}20 \\
180\end{array}$ & $\begin{array}{l}4-71 \\
4-71\end{array}$ & $-\overline{550}$ & $-\overline{149}$ & $\ddot{0}$ & -- & -- \\
\hline $\begin{array}{l}11 N 16 E 256001 \\
11 N 16 E 25 N O 1\end{array}$ & $\begin{array}{l}462446 N 1204332.1 \\
462417 N 1204612.1\end{array}$ & $\begin{array}{l}\text { RILL BLODGETT } \\
\text { JIM HURBARD }\end{array}$ & $\begin{array}{l}1 \\
H\end{array}$ & $\begin{array}{l}1095 \\
1100\end{array}$ & $\begin{array}{r}525 \\
72\end{array}$ & $\begin{array}{l}E L \\
0 A\end{array}$ & $\frac{180}{--}$ & -- & $\begin{array}{r}550 \\
10\end{array}$ & 149 & $\begin{array}{l}0 \\
D \\
D\end{array}$ & 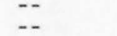 & 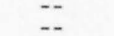 \\
\hline
\end{tabular}




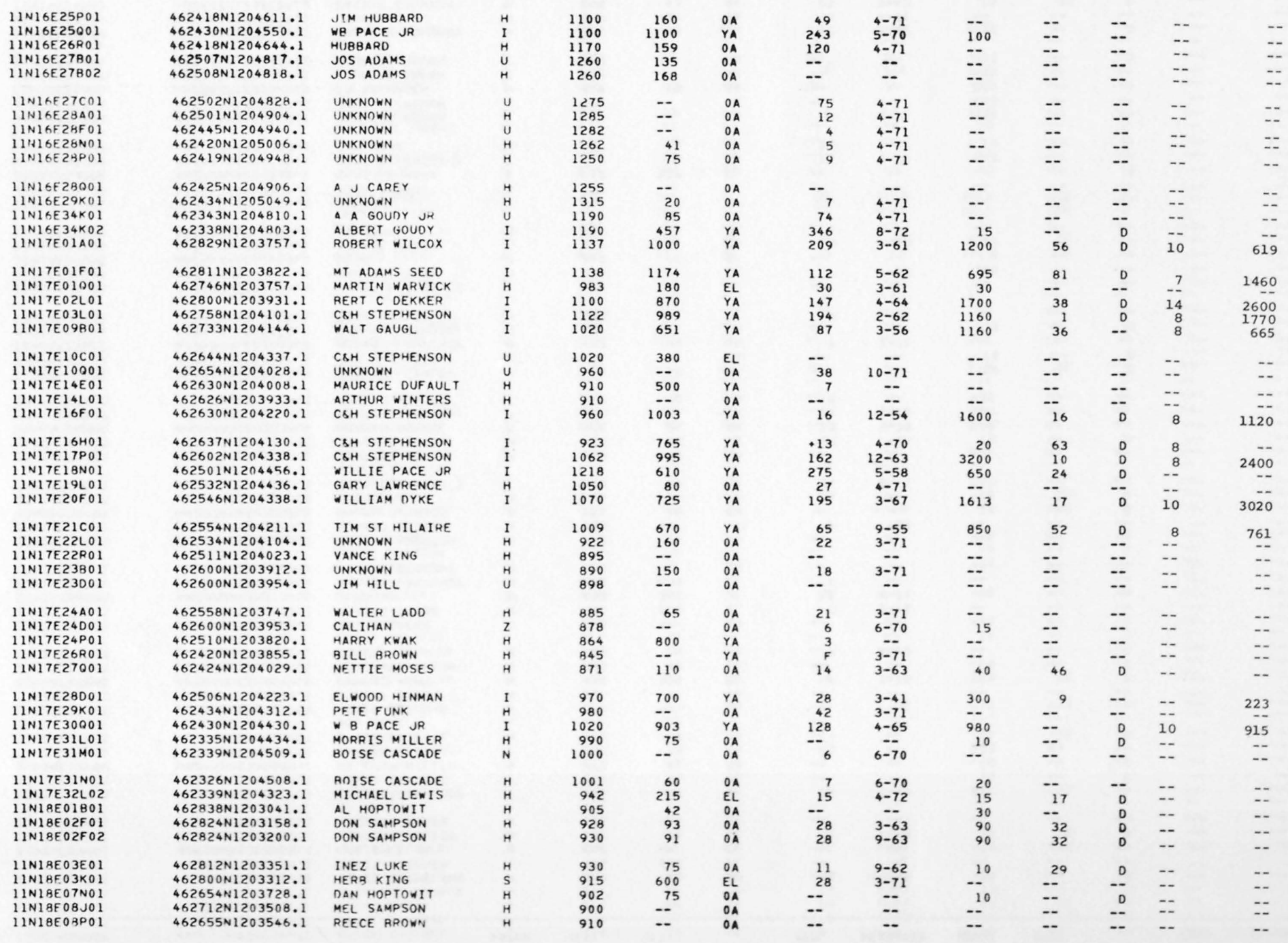


APPENDIX III.--Records of selected wells in the Toppenish Creek basin--Continued

\begin{tabular}{|c|c|c|c|c|c|c|c|c|c|c|c|c|c|}
\hline $\begin{array}{l}\text { LOCAL } \\
\text { WELLL } \\
\text { NUMAER }\end{array}$ & LAT-LONG & OWNER & $\begin{array}{l}\text { USE } \\
\text { OF } \\
\text { WATER }\end{array}$ & $\begin{array}{l}\text { ALTI - } \\
\text { TUDE- } \\
\text { OF LSD } \\
\text { (FT) }\end{array}$ & $\begin{array}{l}\text { WELL } \\
\text { DEPTH } \\
\text { (FT) }\end{array}$ & $\begin{array}{l}\text { MAUOR } \\
\text { AQUIFER }\end{array}$ & $\begin{array}{l}\text { WATER } \\
\text { LEVEL } \\
\text { (FT) }\end{array}$ & $\begin{array}{l}\text { DATE } \\
\text { WATER } \\
\text { LEVEL } \\
\text { MEASURED }\end{array}$ & $\begin{array}{l}\text { YIELD } \\
\text { (GPM) }\end{array}$ & $\begin{array}{l}\text { DRAW } \\
\text { DOWN } \\
\text { (FT) }\end{array}$ & $\begin{array}{l}\text { LOG } \\
\text { AVAIL- } \\
\text { ABLE }\end{array}$ & $\begin{array}{l}\text { Decline, } \\
1971-73 \\
(\mathrm{ft})\end{array}$ & $\begin{array}{l}\text { 2-year } \\
\text { pumpage, } \\
1971-72 \\
\text { (acre-ft) }\end{array}$ \\
\hline $11 \mathrm{N1BE0} 08 \mathrm{RPO}$ & $462655 N 1203512.1$ & NATIE CLEVELAND & H & 880 & 83 & $O A$ & 32 & $12-65$ & 10 & -- & D & $=$ & -- \\
\hline $\begin{array}{l}\text { 11N18E09N01 } \\
11 \text { N1BE09R01 }\end{array}$ & $\begin{array}{l}462656 \mathrm{~N} 1203455.1 \\
462654 \mathrm{~N} 1203355.1\end{array}$ & $\begin{array}{l}\text { MONTE SIEGNER } \\
\text { JOE SHIELDS }\end{array}$ & $\underset{H}{H}$ & $\begin{array}{l}885 \\
902\end{array}$ & 400 & $\underset{E L}{E L}$ & $=$ & $=$ & 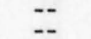 & $=$ & $=$ & $\overline{-}$ & $=$ \\
\hline $11 N 1 B E 1 O E O 1$ & $462732 N 1203349.1$ & ESTHER SPEEDIS & $\mathrm{H}$ & 900 & 75 & ${ }_{O A}$ & 11 & -62 & 10 & 18 & $\overline{0}$ & - & -- \\
\hline IINIBEIIAOI & $462744 \mathrm{N1203122.1}$ & YAKIMA TRIBES & H & 886 & -- & $O A$ & -- & -- & -- & -- & -- & - & -- \\
\hline $\begin{array}{l}11 N 1 B E 12 N 01 \\
11 N 1 B E 12 P 01\end{array}$ & $\begin{array}{l}462654 N 1203117.1 \\
462657 N 1203055: 1\end{array}$ & $\begin{array}{l}\text { STANLEY BRULOTE } \\
\text { HENRY BEAVERT }\end{array}$ & F & $\begin{array}{l}880 \\
875\end{array}$ & 20 & $\begin{array}{l}O A \\
O A\end{array}$ & 13 & $5-70$ & 500 & -- & -- & -- & -- \\
\hline $\begin{array}{l}\text { INIBEILPOI } \\
\text { IINIREISPOZ }\end{array}$ & $462656 \mathrm{~N} 1203059.1$ & $\begin{array}{l}\text { HENRY BEAVERT } \\
\text { *ILLIAM MILLER }\end{array}$ & ${ }_{H}^{H}$ & $\begin{array}{l}875 \\
870\end{array}$ & $\begin{array}{l}44 \\
41\end{array}$ & $\begin{array}{l}O A \\
O A\end{array}$ & $=$ & $=$ & $\begin{array}{l}10 \\
10\end{array}$ & $=$ & $\begin{array}{l}D \\
D\end{array}$ & $=$ & $=$ \\
\hline $\begin{array}{l}11 N 18 E 13 \mathrm{CO} O \\
11 \mathrm{~N} B E 14 \mathrm{EO}\end{array}$ & $462652 N 1203058.1$ & $\begin{array}{l}\text { KEN GASSLING } \\
\text { ANNIF GUYETTE }\end{array}$ & 1 & 835 & 28 & $O A$ & 20 & -- & 500 & $\because$ & $\because$ & $=$ & -- \\
\hline $11 N 18 E 14 E 01$ & $462736 N 1203351 \cdot 1$ & ANNIE GUYETTE & $\mathrm{H}$ & 883 & 52 & $O A$ & 15 & -- & 10 & 15 & D & -- & -- \\
\hline $\begin{array}{l}\text { 11N1BE } 15 \mathrm{NO} 1 \\
11 \mathrm{NIAE} 16 \mathrm{MO} 01\end{array}$ & $\begin{array}{l}462602 N 1203347.1 \\
462621 N 1203450.1\end{array}$ & $\begin{array}{l}\text { ERVIN WEI JOHN } \\
\text { RORERT BROWN }\end{array}$ & ${ }_{H}^{H}$ & $\begin{array}{l}870 \\
865\end{array}$ & $=$ & $\begin{array}{l}O A \\
O A\end{array}$ & $=$ & $=$ & $=$ & $=$ & $=$ & $=$ & $=$ \\
\hline $11 N 18 E 17 B 01$ & $462652 N 1203537.1$ & CONPAD MERT & $\mathrm{H}$ & $\begin{array}{l}865 \\
880\end{array}$ & 625 & EL & $F$ & $7-70$ & 500 & 10 & 0 & - & 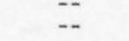 \\
\hline $\begin{array}{l}11 \mathrm{~N} 18 F 17001 \\
11 \mathrm{N1BE} 17002\end{array}$ & $\begin{array}{l}462651 \mathrm{~N} 1203604: 1 \\
462651 \mathrm{~N} 1203621.1\end{array}$ & $\begin{array}{l}\text { VIRGINIA BUENO } \\
\text { USGS }\end{array}$ & $\underset{u}{H}$ & $\begin{array}{l}885 \\
880\end{array}$ & $\begin{array}{l}68 \\
84\end{array}$ & $\begin{array}{l}O A \\
O A \\
O A\end{array}$ & $-{ }_{8}$ & $=-72$ & 10 & $\because-$ & D & -- & -- \\
\hline $11 N 18 E 17401$ & $462637 N 1203508.1$ & RAY POIRFIR & H & 868 & -- & $O A$ & -- & -- & -- & -- & -- & -- & 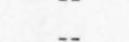 \\
\hline $11 N 18 E 17 L 01$ & $462626 \mathrm{~N} 12036 \mathrm{Cl} 1.1$ & YAKINA TRIBE & u & 875 & 283 & EL & $\mathrm{F}$ & $5-70$ & -- & -- & -- & -- & $=$ \\
\hline $\begin{array}{l}11 N 18 E 1 B E 02 \\
11 N 1 B E\end{array}$ & $\begin{array}{l}462638 N 1203736.1 \\
4652509 N 1203633\end{array}$ & UNKNOWN & $u$ & $\begin{array}{l}895 \\
865\end{array}$ & 260 & EL & 11 & $8-71$ & -- & -- & -- & $=$ & $=$ \\
\hline $\begin{array}{l}11 N 1 R E 20001 \\
11\end{array}$ & $\begin{array}{l}462509 \mathrm{~N} 1203623.1 \\
462554 \mathrm{~N} 1203621.1\end{array}$ & $\begin{array}{l}\text { MARVIN LAWRENCE } \\
\text { WCHILPEROORT }\end{array}$ & $\stackrel{\mathrm{H}}{\mathrm{H}}$ & $\begin{array}{l}865 \\
860\end{array}$ & $\begin{array}{l}580 \\
--\end{array}$ & $\begin{array}{l}E L \\
O A\end{array}$ & $--^{F}$ & $=$ & $=$ & $=$ & $=$ & $=$ & $=$ \\
\hline 11N1REZOE 01 & $462536 N 1203616.1$ & METTY CHRISTEN & H & 862 & 190 & $O A$ & -- & -- & -- & -- & -- & $=$ & -- \\
\hline $\begin{array}{l}11 N 18 F 20001 \\
11 N 18 E 21 F 01\end{array}$ & $\begin{array}{l}462510 N 1203529 \cdot 1 \\
462536 N 1203502.1\end{array}$ & $\begin{array}{l}\text { ALLERT WEGGE } \\
\text { RALPH SAMPSON }\end{array}$ & ${ }_{H}^{H}$ & $\begin{array}{l}850 \\
851\end{array}$ & $-\overline{65}$ & $\overline{O_{A}}$ & $\ldots F$ & -63 & 70 & $=$ & $\overline{0}$ & -- &.- \\
\hline IINIBEZZROI & $462510 N 1203236.1$ & BQONCHEAU & $\mathrm{H}$ & 840 & 49 & $O A$ & 14 & $\ldots$ & 15 & 16 & D & $\ldots$ & - \\
\hline IINIBEZ24DOI & $462600 N 1203104.1$ & FIRE DISTHICT 5 & $\mathbf{F}$ & 860 & 22 & $O A$ & 14 & $8-71$ & 500 & -- & -- & -- & -- \\
\hline 11N1BE24J0 1 & $\begin{array}{l}462534 N 1203010.1 \\
462442 N 1203214: 1\end{array}$ & $\begin{array}{l}\text { RENNETT OLSEN } \\
\text { SARAH CARLSON }\end{array}$ & H & $\begin{array}{l}849 \\
835\end{array}$ & 32 & $\begin{array}{l}O A \\
O A\end{array}$ & $\because$ & $=-$ & - & $=$ & -- & $=$ & -- \\
\hline 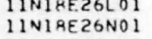 & $\begin{array}{l}462442 N 1203314.1 \\
462426 N 1203234.1\end{array}$ & $\begin{array}{l}\text { SARAH CARLSON } \\
\text { HARPAH SCHOLL }\end{array}$ & $\stackrel{H}{F}$ & $\begin{array}{l}835 \\
830\end{array}$ & $\begin{array}{l}52 \\
24\end{array}$ & $\begin{array}{l}O A \\
O A\end{array}$ & $\begin{array}{l}12 \\
13\end{array}$ & $\begin{array}{r}-65 \\
5-70\end{array}$ & $\begin{array}{r}10 \\
500\end{array}$ & $\because$ & $\therefore$ & $\because$ & $=$ \\
\hline IINIBEZSNOZ & $462426 N 1203228.1$ & HARRAH SCHOOL & F & 830 & 24 & $O A$ & 13 & $5-70$ & 500 & -- & -- & -- & -- \\
\hline IINIAE 26 NO 3 & $462421 \mathrm{N1203234.1}$ & HARRAH SCHOOL & $\mathrm{f}$ & 830 & 20 & $O A$ & 10 & -- & 500 & -- & -- & -- & -- \\
\hline $\begin{array}{l}\text { 11N1BE26001 } \\
11 \text { N1BE28HO1 }\end{array}$ & $\begin{array}{l}462418 N 1203152.1 \\
4 h 2444 N 1203351=1\end{array}$ & $\begin{array}{l}\text { RICHARD FINLEY } \\
\text { TFD PHILLIPS }\end{array}$ & H & 828 & 50 & $O A$ & -- & -- & 10 & -- & 0 & -- & -- \\
\hline $\begin{array}{l}11 N 18 E 29002 \\
1118 E 2\end{array}$ & $\begin{array}{l}424444 N 1203351.1 \\
462507 N 1203603.1\end{array}$ & $\begin{array}{l}\text { TEN PHILLIPS } \\
\text { MARVIN LAWRENCE }\end{array}$ & ${ }_{H}^{H}$ & $\begin{array}{l}831 \\
852\end{array}$ & $\begin{array}{l}51 \\
90\end{array}$ & $\begin{array}{l}O A \\
O A\end{array}$ & $\overline{-}_{7}$ & $3-71$ & -2 & $=$ & - & & $=$ \\
\hline $\begin{array}{l}\text { 11N18F29P01 } \\
11 \mathrm{N1BE} 30 \mathrm{OOH}\end{array}$ & $\begin{array}{l}462417 N 1203600.1 \\
462447 N 1203637.1\end{array}$ & $\begin{array}{l}\text { RENNY RUAEMPTS } \\
\text { DICK BOISSELLLE }\end{array}$ & ${ }_{H}^{H}$ & $\begin{array}{l}852 \\
855\end{array}$ & $\begin{array}{r}70 \\
544\end{array}$ & $\begin{array}{l}O A \\
E L\end{array}$ & $--_{F}$ & $5-71$ & 10 & -- & 0 & -- & -- \\
\hline & & & & & & & & & -- & $\cdots$ & -- & $\cdots$ & -- \\
\hline $\begin{array}{l}\text { 11N1BE30J01 } \\
11 \mathrm{~N} 1 \mathrm{BE} 30 \mathrm{OOO}\end{array}$ & $\begin{array}{l}462433 N 1203624: 1 \\
462421 N 1203641\end{array}$ & $\begin{array}{l}\text { ELMER BOISSELLE } \\
\text { MAURIE ROWE }\end{array}$ & H & 855 & $=$ & $O A$ & $-\bar{c}^{-}$ & $=-6$ & $\overline{300}$ & $=$ & -- & -- & -- \\
\hline $\begin{array}{l}11 N 18 E 32001 \\
1121803001\end{array}$ & $462407 N 1203630.1$ & USGS & u & 840 & -75 & $O A$ & $\ldots$ & 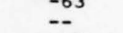 & $\begin{array}{l}300 \\
8\end{array}$ & -- & $=$ & $=$ & $=$ \\
\hline $11 N 1 B E 33 D O 1$ & $462413 N 1203454.1$ & GEORGE HENRY & H & 810 & 54 & $O A$ & 25 & -63 & 12 & - & - & -- & $=$ \\
\hline I INIBE 33 NOI & $462325 N 1203456.1$ & 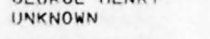 & H & 830 & 56 & $O A$ & 16 & $5-71$ & -- & -- & - & -- & $=$ \\
\hline $\begin{array}{l}\text { 11N1BE34RO1 } \\
11 \mathrm{~N} B E 34 \mathrm{JOO}\end{array}$ & $\begin{array}{l}462415 N 1203254.1 \\
462342 N 1203238.1\end{array}$ & $\begin{array}{l}\text { UNKNOWN } \\
\text { RICK KNIGHT }\end{array}$ & I & $\begin{array}{l}825 \\
823\end{array}$ & $\ldots 17$ & $\begin{array}{l}O A \\
O A\end{array}$ & _-9 & $\begin{array}{l}7-71 \\
--\end{array}$ & $=$ & $=$ & $\because$ & $=$ & $=$ \\
\hline $\begin{array}{l}11 \mathrm{~N} 18 E 34 \mathrm{JO} 01 \\
11 \mathrm{N1} \text { BE } 34 \mathrm{P} 01\end{array}$ & $462328 N 1203314.1$ & CHAS ST MARX & I & 812 & 512 & $E L$ & -- & $=$ & $=$ & $\bar{z}+$ & $\overline{0}$ & - & -- \\
\hline $11 N 1$ SE 35001 & $462411 N 1203235.1$ & FIRE DISTRICT 5 & $\mathrm{~F}$ & 830 & 16 & $O A$ & 15 & $5-70$ & 500 & -- & -- & - & - \\
\hline IINIOE 35 NOI & $462327 \mathrm{~N} 1203233.1$ & EVA HAWK & H & 817 & 64 & $O A$ & 17 & $4-67$ & 10 & -- & -- & -- & -- \\
\hline 1IN1 AE 36D01 & $462411 N 1203107.1$ & MAURICE PEUGH & I & 825 & $=$ & $O A$ & 9 & $8-71$ & 450 & -- & -- & -- & -- \\
\hline $11 N 18$ & $\begin{array}{l}462358 N 12 \\
462340 N 12\end{array}$ & $\begin{array}{l}\text { MAURICE PEUGH } \\
\text { FD }\end{array}$ & I & $\begin{array}{l}824 \\
820\end{array}$ & 7 & OA & -- & & 330 & -- & -- & -- & -- \\
\hline $\begin{array}{l}11 N 1 \text { AE } 36 J 01 \\
\text { IINIBE } 36401\end{array}$ & & $\begin{array}{l}\text { FD BACHMIER } \\
\text { MAURICE PEUGH }\end{array}$ & ${ }_{I}^{H}$ & $\begin{array}{l}820 \\
822\end{array}$ & 19 & $O_{A}^{A A}$ & $=$ & $=$ & $\begin{array}{l}320 \\
600\end{array}$ & $=$ & $=$ & $z$ & $=$ \\
\hline 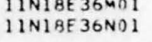 & $\begin{array}{l}462347 N 1203107.1 \\
462334 N 1203107.1\end{array}$ & $\begin{array}{l}\text { MAURICE PEUGH } \\
\text { MAURICE PEUGH }\end{array}$ & $\begin{array}{l}1 \\
1\end{array}$ & $\begin{array}{l}822 \\
819\end{array}$ & $\ddot{z}$ & $\begin{array}{l}O A \\
O A\end{array}$ & $=$ & $=$ & $\begin{array}{l}600 \\
600\end{array}$ & $=$ & $\overline{0}$ & $=$ & $=$ \\
\hline 11N19E0ZLO2 & $462758 N 1202438.1$ & CELIA U JOHNSON & H & 861 & 43 & $O A$ & 12 & $5-62$ & 15 & -- & o & -- & -- \\
\hline $\begin{array}{l}11 N 19 E 03 J 01 \\
11 N 19 E 041101\end{array}$ & $\begin{array}{l}46280301202507.1 \\
462837 N 1202725.1\end{array}$ & $\begin{array}{l}\text { JOHNSSN } \\
\text { CASSIE COLWASH }\end{array}$ & $\mathrm{U}_{\mathrm{H}}$ & $\begin{array}{l}869 \\
895\end{array}$ & $\begin{array}{l}22 \\
43\end{array}$ & $\begin{array}{l}{ }_{0 A}^{O A} \\
{ }_{A}\end{array}$ & $\begin{array}{r}88 \\
23\end{array}$ & $\begin{array}{l}\begin{array}{l}7-71 \\
3-63\end{array} \\
-63\end{array}$ & 15 & 35 & $\overline{0}$ & - & $=$ \\
\hline $\begin{array}{l}11 \mathrm{N1} 9 E 04 \mathrm{HOI} \\
\end{array}$ & $462823 N 1202620.1$ & NINA WOODS & H & 878 & 42 & $O A$ & 8 & $7-62$ & 10 & 11 & D & $=$ & $=$ \\
\hline 11N1 QE 05601 & $462822 N 1202751.1$ & HUDON & I & 895 & 20 & $O A$ & 9 & $8-71$ & -- & -- & -- & -- & -- \\
\hline
\end{tabular}




\begin{tabular}{|c|c|c|c|c|c|c|c|c|c|c|c|c|c|}
\hline $\begin{array}{l}\text { 11N19E05HO1 } \\
11 N 19 E 05 M 02 \\
11 N 19 E 06 F 01 \\
11 N 19 E 07 L 01 \\
11 N 19 E 07 M 01\end{array}$ & $\begin{array}{l}462823 N 1202732.1 \\
462800 N 1202840.1 \\
462822 N 1202936.1 \\
462713 N 1202928.1 \\
462714 N 1202945.1\end{array}$ & $\begin{array}{l}\text { C K VILLLNIANN } \\
\text { UNKNOWN } \\
\text { DICK COWIN } \\
C L \text { \& FRANK } \\
L C \& \text { FRANK }\end{array}$ & $\begin{array}{l}I \\
\text { H } \\
\text { H } \\
\text { I } \\
\text { I }\end{array}$ & $\begin{array}{l}890 \\
892 \\
894 \\
877 \\
877\end{array}$ & $\begin{array}{r}20 \\
-- \\
50 \\
22 \\
25\end{array}$ & $\begin{array}{l}\text { OA } \\
\text { OA } \\
\text { OA } \\
\text { OA } \\
\text { OA }\end{array}$ & $\begin{array}{l}-- \\
--8 \\
--\end{array}$ & $\begin{array}{l}-- \\
8-71 \\
=-71 \\
7--\end{array}$ & $\begin{array}{l}200 \\
-- \\
-- \\
450 \\
450\end{array}$ & $\begin{array}{l}-- \\
=- \\
z- \\
=-\end{array}$ & $\begin{array}{l}=- \\
=- \\
= \\
0\end{array}$ & $\begin{array}{l}=- \\
-- \\
=- \\
--\end{array}$ & $\begin{array}{l}-- \\
-z \\
z-\end{array}$ \\
\hline $\begin{array}{l}\text { 11N19E07N01 } \\
\text { 11N19E0BNO1 } \\
\text { 11N19E08R01 } \\
\text { 11N19E09K03 } \\
\text { 11N19E09R01 }\end{array}$ & $\begin{array}{l}462703 N 1202958.1 \\
462655 N 1202838.1 \\
462565 N 1202733.1 \\
462614 N 1202641.1 \\
462611 N 1202858.1\end{array}$ & $\begin{array}{l}\text { L C \& F FRANK } \\
\text { CLARENCE TAHKEL } \\
\text { CALHOUN } \\
\text { JOHN SMARTLOWIT } \\
\text { JOHN EYLE }\end{array}$ & $\begin{array}{l}\mathrm{I} \\
\mathrm{H} \\
\mathrm{C} \\
\mathrm{H} \\
\mathrm{H}\end{array}$ & $\begin{array}{l}875 \\
874 \\
868 \\
867 \\
864\end{array}$ & $\begin{array}{l}23 \\
51 \\
49 \\
50 \\
49\end{array}$ & $\begin{array}{l}O A \\
O A \\
O A \\
O A \\
O A\end{array}$ & $\begin{array}{l}-4 \\
-- \\
--\end{array}$ & $\begin{array}{l}= \\
=- \\
=-\end{array}$ & $\begin{array}{r}400 \\
10 \\
-- \\
10 \\
10\end{array}$ & $\begin{array}{l}=- \\
=- \\
=- \\
--\end{array}$ & $\begin{array}{c}-- \\
0 \\
0 \\
-0\end{array}$ & $\begin{array}{l}= \\
z- \\
z \\
z\end{array}$ & $\begin{array}{l}z- \\
=- \\
z- \\
--\end{array}$ \\
\hline $\begin{array}{l}\text { 11N19E10A01 } \\
1 \text { NN19E1OBO1 } \\
11 N 19 E 10 H 01 \\
1119 E 10001 \\
11 N 19 E 10002\end{array}$ & $\begin{array}{l}462737 N 1202502.1 \\
462738 N 1202526.1 \\
462731 N 120245.1 \\
462703 N 1202523.1 \\
462705 N 1202524.1\end{array}$ & $\begin{array}{l}\text { YAKIMA TRIBE } \\
\text { YAKIMA TRIBE } \\
\text { ROBERT JIM } \\
\text { WAPATO CITY } \\
\text { WAPATO CITY }\end{array}$ & $\begin{array}{l}P \\
p \\
H \\
P \\
P\end{array}$ & $\begin{array}{l}860 \\
860 \\
859 \\
860 \\
860\end{array}$ & $\begin{array}{l}700 \\
765 \\
41 \\
765 \\
750\end{array}$ & $\begin{array}{l}E L \\
E L \\
O A \\
E L \\
E L\end{array}$ & $\begin{array}{r}32 \\
57 \\
-- \\
30 \\
30\end{array}$ & $\begin{array}{l}7-69 \\
9-69 \\
-- \\
1-65 \\
1-65\end{array}$ & $\begin{array}{r}1520 \\
1266 \\
10 \\
650 \\
1000\end{array}$ & $\begin{array}{r}105 \\
188 \\
--72 \\
95\end{array}$ & $\begin{array}{r}0 \\
0 \\
-0 \\
0 \\
D\end{array}$ & $\begin{array}{l}-- \\
z- \\
--\end{array}$ & $\begin{array}{l}-- \\
=- \\
--\end{array}$ \\
\hline $\begin{array}{l}11 N 19 E 11 F 01 \\
11 N 19 E 13802 \\
11 N 19 E 13 K 01 \\
11 N 19 E 14001 \\
11 N 19 E 15 A 01\end{array}$ & $\begin{array}{l}462721 N 1202424.1 \\
462651 N 1202244.1 \\
462614 N 1202256.1 \\
462652 N 1202442.1 \\
462648 N 1202502.1\end{array}$ & $\begin{array}{l}\text { WALLY SEELAM } \\
\text { WILLIAM MILLER } \\
\text { HOWARD WAMPAT } \\
\text { CAROLINE STRONG } \\
\text { WAPATO CITY }\end{array}$ & $\begin{array}{l}H \\
H \\
H \\
H \\
U\end{array}$ & $\begin{array}{l}853 \\
831 \\
825 \\
852 \\
850\end{array}$ & $\begin{array}{r}42 \\
50 \\
43 \\
43 \\
975\end{array}$ & $\begin{array}{l}O A \\
O A \\
O A \\
O A \\
E L\end{array}$ & $\begin{array}{r}-- \\
14 \\
-- \\
--\end{array}$ & $\begin{array}{l}=- \\
7=71 \\
=- \\
=\end{array}$ & $\begin{array}{r}10 \\
-10 \\
10 \\
300\end{array}$ & $\begin{array}{l}= \\
z- \\
=\end{array}$ & $\begin{array}{c}0 \\
-0 \\
0 \\
0 \\
0\end{array}$ & $\begin{array}{l}z- \\
z- \\
z- \\
z\end{array}$ & $\begin{array}{l}=- \\
=- \\
=- \\
z\end{array}$ \\
\hline $\begin{array}{l}\text { 11N19E15A02 } \\
\text { 11N19E15E01 } \\
\text { 1NN19E16A02 } \\
\text { 11N19E16J01 } \\
\text { 11N19E16RO2 }\end{array}$ & $\begin{array}{l}462648 \mathrm{~N} 1202502.2 \\
462634 \mathrm{N1202503} .1 \\
462652 \mathrm{~N} 1202614.1 \\
462614 \mathrm{~N} 1202621.1 \\
462604 \mathrm{~N} 1202614.1\end{array}$ & $\begin{array}{l}\text { WAPATO CITY } \\
\text { BEAVERT } \\
\text { MINNIE ANDREWS } \\
\text { WILLIAM CLAYTON } \\
\text { CLYDE CALAHAN }\end{array}$ & $\begin{array}{l}U \\
H \\
H \\
H \\
I \\
I\end{array}$ & $\begin{array}{l}850 \\
854 \\
857 \\
850 \\
852\end{array}$ & $\begin{array}{l}-- \\
50 \\
52 \\
52 \\
15\end{array}$ & $\begin{array}{l}E L \\
O A \\
O A \\
O A \\
O A\end{array}$ & $\begin{array}{l}-= \\
=- \\
-- \\
--\end{array}$ & $\begin{array}{l}z \\
z- \\
z\end{array}$ & $\begin{array}{r}714 \\
10 \\
10 \\
-- \\
200\end{array}$ & $\begin{array}{l}30 \\
-- \\
-- \\
--\end{array}$ & $\begin{array}{r}-- \\
0 \\
0 \\
--\end{array}$ & $\begin{array}{l}-- \\
=- \\
-- \\
--\end{array}$ & $\begin{array}{l}-- \\
=- \\
z- \\
--\end{array}$ \\
\hline $\begin{array}{l}11 N 19 E 17 R 01 \\
11 N 19 E 18 P 01 \\
11 N 19 E 19 R 01 \\
11 N 19 E 20001 \\
11 N 19 E 21002\end{array}$ & $\begin{array}{l}462614 \mathrm{~N} 1202736.1 \\
462607 \mathrm{~N} 1202854.1 \\
462510 \mathrm{~N} 120257.1 \\
46518 \mathrm{~N} 1202748.1 \\
462511 \mathrm{~N} 1202650.1\end{array}$ & $\begin{array}{l}\text { WESLEY CALAHAN } \\
\text { JOHN GOOSZHANS } \\
\text { SAM NISHI } \\
\text { ROY HOWAPD } \\
\text { LORENE SOHAPPY }\end{array}$ & $\begin{array}{l}\mathrm{I} \\
\mathrm{I} \\
\mathrm{H} \\
\mathrm{H} \\
\mathrm{H}\end{array}$ & $\begin{array}{l}860 \\
856 \\
840 \\
843 \\
840\end{array}$ & $\begin{array}{l}-- \\
19 \\
26 \\
50 \\
59\end{array}$ & $\begin{array}{l}O A \\
O A \\
O A \\
O A \\
O A \\
O A\end{array}$ & $\begin{array}{c}-- \\
--9 \\
18 \\
17\end{array}$ & $\begin{array}{c}=- \\
9-72 \\
=- \\
2-66\end{array}$ & $\begin{array}{l}600 \\
-- \\
11 \\
10\end{array}$ & $\begin{array}{l}-- \\
-- \\
17 \\
18\end{array}$ & $\begin{array}{c}-- \\
-z \\
-\overline{0} \\
0\end{array}$ & $\begin{array}{l}z- \\
z- \\
z- \\
z\end{array}$ & $\begin{array}{l}=- \\
z= \\
z\end{array}$ \\
\hline $\begin{array}{l}11 N 19 E 22 A 04 \\
11 N 19 F 22 . J 01 \\
11 N 19 E 23001 \\
11 N 19 E 24 F 01 \\
11 N 19 E 24 R 01\end{array}$ & $\begin{array}{l}462511 \mathrm{~N} 1202858.1 \\
462533 \mathrm{~N} 1202500.1 \\
462509 \mathrm{~N} 12020404.1 \\
462535 \mathrm{~N} 1202322.1 \\
462509 \mathrm{~N} 1202229.1\end{array}$ & $\begin{array}{l}\text { JAMES SHIKE } \\
\text { DORIS SIMPSON } \\
\text { EDNA SCCNAWAH } \\
\text { UNKNOWN } \\
\text { DUANE CLARK }\end{array}$ & $\begin{array}{l}H \\
H \\
H \\
H \\
H\end{array}$ & $\begin{array}{l}837 \\
832 \\
822 \\
821 \\
808\end{array}$ & $\begin{array}{r}51 \\
48 \\
51 \\
-- \\
41\end{array}$ & $\begin{array}{l}O A \\
O A \\
O A \\
O A \\
O A\end{array}$ & $\begin{array}{l}=- \\
=- \\
-- \\
16\end{array}$ & $\begin{array}{l}z \\
z- \\
z \\
z\end{array}$ & $\begin{array}{r}10 \\
10 \\
10 \\
-10\end{array}$ & $\begin{array}{l}=- \\
=- \\
= \\
=\end{array}$ & $\begin{array}{c}0 \\
0 \\
-\because \\
-0\end{array}$ & $\begin{array}{l}-- \\
z- \\
-- \\
--\end{array}$ & $\begin{array}{l}= \\
=- \\
=- \\
=\end{array}$ \\
\hline $\begin{array}{l}11 N 19 E 26 A 01 \\
11 N 19 E 26 C 01 \\
11 N 19 E 27002 \\
11 N 19 E 27 H 01 \\
11 N 19 E 28 B 01\end{array}$ & $\begin{array}{l}462507 N 1202347.1 \\
462506 N 1202436.1 \\
462508 N 1202556.1 \\
462447 N 1202505.1 \\
462504 N 1202641.1\end{array}$ & $\begin{array}{l}\text { BEN OUGH } \\
\text { SUSAN SMATTIE } \\
\text { CALVIN CHARLEY } \\
\text { ALLEN JAY } \\
\text { WILFRED YALLUP }\end{array}$ & $\begin{array}{l}H \\
H \\
H \\
H \\
H\end{array}$ & $\begin{array}{l}818 \\
826 \\
833 \\
822 \\
838\end{array}$ & $\begin{array}{l}46 \\
50 \\
50 \\
35 \\
51\end{array}$ & $\begin{array}{l}O A \\
O A \\
O A \\
O A \\
O A\end{array}$ & $\begin{array}{l}=- \\
=- \\
=- \\
16\end{array}$ & $\begin{array}{l}z \\
z \\
z\end{array}$ & $\begin{array}{c}15 \\
10 \\
-- \\
-10\end{array}$ & $\begin{array}{l}=- \\
=- \\
= \\
19\end{array}$ & $\begin{array}{r}0 \\
0 \\
-\therefore \\
-0\end{array}$ & $\begin{array}{l}z- \\
z- \\
=- \\
--\end{array}$ & $\begin{array}{l}= \\
=- \\
= \\
=\end{array}$ \\
\hline $\begin{array}{l}11 N 19 E 28 B 02 \\
11 N 19 F 28 J 02 \\
11 N 19 E 29001 \\
11 N 19 E 30 D 01 \\
11 N 19 E 30 J 01\end{array}$ & $\begin{array}{l}462507 N 1202636.1 \\
462442 N 1202616.1 \\
462426 N 1202759.1 \\
462508 N 1202952.1 \\
462437 N 1202848.1\end{array}$ & $\begin{array}{l}\text { JUL IA SOHAPPY } \\
\text { BOB BEAM } \\
\text { N HERNANOEZ } \\
\text { FAIRBANSS DOUG } \\
\text { EP GAILAN }\end{array}$ & $\begin{array}{l}H \\
H \\
H \\
I \\
H\end{array}$ & $\begin{array}{l}838 \\
828 \\
833 \\
840 \\
835\end{array}$ & $\begin{array}{r}51 \\
22 \\
120 \\
8 \\
32\end{array}$ & $\begin{array}{l}\text { OA } \\
0 A \\
0 A \\
O A \\
O A\end{array}$ & $\begin{array}{l}24 \\
-- \\
=- \\
--\end{array}$ & $\begin{array}{l}4-72 \\
-- \\
-- \\
--\end{array}$ & $\begin{array}{l}12 \\
-- \\
500 \\
--\end{array}$ & $\begin{array}{l}-{ }^{3} \\
-- \\
--\end{array}$ & $\begin{array}{l}0 \\
-\because- \\
--\end{array}$ & $\begin{array}{l}z- \\
z- \\
z\end{array}$ & $\begin{array}{l}= \\
=- \\
= \\
=\end{array}$ \\
\hline $\begin{array}{l}\text { 11N19E30NO1 } \\
\text { IIN19E3ODO1 } \\
11 N 19 E 31 M 01 \\
11 N 19 E 32 M O 1 \\
11 N 19 E 32 H 01\end{array}$ & $\begin{array}{l}462419 \mathrm{~N} 1202945.1 \\
462419 \mathrm{~N} 1202939.1 \\
462348 \mathrm{~N} 1203001.1 \\
462345 \mathrm{~N} 1202834.1 \\
462334 \mathrm{~N} 1202732.1\end{array}$ & $\begin{array}{l}\text { INDIAN RANCHES } \\
\text { RF CLARK } \\
\text { JOHN WINTERS } \\
\text { L RIPLFY } \\
\text { JULIA SETTLER }\end{array}$ & $\begin{array}{l}C \\
H \\
H \\
H \\
H\end{array}$ & $\begin{array}{l}830 \\
828 \\
820 \\
822 \\
815\end{array}$ & $\begin{array}{l}69 \\
38 \\
40 \\
62 \\
60\end{array}$ & $\begin{array}{l}O A \\
0 A \\
0 A \\
0 A \\
0 A \\
O A\end{array}$ & $\begin{array}{l}9 \\
-- \\
14 \\
10\end{array}$ & $\begin{array}{c}11-69 \\
-- \\
-- \\
4-67 \\
4-67\end{array}$ & $\begin{array}{l}850 \\
\because- \\
11 \\
10\end{array}$ & $\begin{array}{l}32 \\
-- \\
14 \\
12\end{array}$ & $\begin{array}{l}= \\
z \\
z \\
=\end{array}$ & $\begin{array}{l}-z \\
z- \\
-z \\
-=\end{array}$ & $\begin{array}{l}= \\
=- \\
= \\
--\end{array}$ \\
\hline $\begin{array}{l}11 N 19 E 33001 \\
11 N 19 E 34001 \\
11 N 19 E 34 M 01 \\
11 N 10 E 34 D 01 \\
11 N 19 E 35 A 01\end{array}$ & $\begin{array}{l}462416 \mathrm{~N} 1202724.1 \\
462413 \mathrm{~N} 1202600.1 \\
462348 \mathrm{~N} 1202611.1 \\
462328 \mathrm{~N} 1202459.1 \\
462413 \mathrm{~N} 1202347.1\end{array}$ & $\begin{array}{l}\text { LF ZWIESLER CO } \\
\text { CLARENCE KAHAMA } \\
\text { PEDRO BATIN } \\
\text { MENRY TAKKEAL } \\
\text { ELTON KRUEGER }\end{array}$ & $\begin{array}{l}\mathrm{H} \\
\mathrm{H} \\
\mathrm{H} \\
\mathrm{H} \\
\mathrm{H}\end{array}$ & $\begin{array}{l}830 \\
820 \\
818 \\
805 \\
810\end{array}$ & $\begin{array}{l}27 \\
65 \\
64 \\
57 \\
12\end{array}$ & $\begin{array}{l}\text { OA } \\
0 A \\
0 A \\
0 A \\
O A\end{array}$ & $\begin{array}{l}-- \\
10 \\
16 \\
18 \\
--\end{array}$ & $\begin{array}{l}-- \\
5-67 \\
4-67 \\
4-67 \\
--\end{array}$ & $\begin{array}{r}-10 \\
11 \\
10 \\
300\end{array}$ & $\begin{array}{l}-- \\
-- \\
31 \\
13 \\
--\end{array}$ & $\begin{array}{r}-- \\
0 \\
-0\end{array}$ & $\begin{array}{l}z= \\
z- \\
z\end{array}$ & $\begin{array}{l}= \\
z \\
z\end{array}$ \\
\hline
\end{tabular}


APPENDIX III.--Records of selected wells in the Toppenish Creek basin--Continued

\begin{tabular}{|c|c|c|c|c|c|c|c|c|c|c|c|c|c|}
\hline $\begin{array}{l}\text { LOCAL } \\
\text { WELLL } \\
\text { NUMRER }\end{array}$ & LAT-LONG & OWNER & $\begin{array}{l}\text { USE } \\
\text { OF } \\
\text { WATER }\end{array}$ & $\begin{array}{l}\text { ALTII- } \\
\text { TUDE- } \\
\text { OF LSD } \\
\text { (FT) }\end{array}$ & $\begin{array}{l}\text { WELL } \\
\text { DEPTH } \\
\text { (FT) }\end{array}$ & $\begin{array}{c}\text { MA OOR } \\
\text { AQUIFER }\end{array}$ & $\begin{array}{l}\text { WATER } \\
\text { LEVELL } \\
\text { (FF) }\end{array}$ & $\begin{array}{l}\text { DATE } \\
\text { WATER } \\
\text { LEVEL } \\
\text { MEASURED }\end{array}$ & $\begin{array}{l}\text { YIELD } \\
\text { (GPM) }\end{array}$ & $\begin{array}{l}\text { DRAW } \\
\text { DOWN } \\
\text { (FT) }\end{array}$ & $\begin{array}{l}\text { LOG } \\
\text { AVAIL- } \\
\text { ABLE }\end{array}$ & $\begin{array}{l}\text { Decline, } \\
1971-73 \\
(\mathrm{ft})\end{array}$ & $\begin{array}{l}\text { 2-year } \\
\text { pumpage, } \\
1971-72 \\
(\text { acre-ft) }\end{array}$ \\
\hline $11 N 19 E 35601$ & $\begin{array}{l}462402 N 1202420.1 \\
46327 N 120243\end{array}$ & ALVIN PINKHAM & H & 812 & 61 & $O A$ & 19 & $3-67$ & 10 & $=$ & $\therefore$ & $=$ & $z$ \\
\hline $\begin{array}{l}11 \mathrm{~N} 19 \mathrm{3} .35 \mathrm{NON} 1 \\
11 \mathrm{~N} 19.36001\end{array}$ & $\begin{array}{l}462327 N 1202443.1 \\
462326 N 1202304.1\end{array}$ & $\begin{array}{l}\text { DAVE GREER } \\
\text { EVERYBODY SAM }\end{array}$ & $\underset{H}{H}$ & $\begin{array}{l}802 \\
790\end{array}$ & $\begin{array}{r}100 \\
56\end{array}$ & $\begin{array}{l}O A \\
O A\end{array}$ & $\overline{13}$ & $1-67$ & 10 & 1 & $\overline{0}$ & -. & -. \\
\hline $\begin{array}{l}11 N 19636001 \\
11 N 19 F 36002\end{array}$ & $462326 \mathrm{~N} 1202256.1$ & INA WHITE & H & 790 & 60 & $O_{A}$ & 14 & $1-67$ & 10 & -- & -- & - & $=$ \\
\hline 11N20E07H01 & $462719 \times 1202133.1$ & SNO KIST & $\mathrm{N}$ & 831 & 165 & $O A$ & 9 & $3-71$ & -- & -- & -- & -- & -- \\
\hline 11 N20E19001 & $\begin{array}{l}462558 \mathrm{~N} 1202222.1 \\
462523 \mathrm{~N} 202209\end{array}$ & $\begin{array}{l}\text { BILL ROOT } \\
\text { CELIA POHNSON }\end{array}$ & $U_{H}$ & & 39 & $O A$ & 11 & $=$ & $\begin{array}{l}10 \\
10\end{array}$ & $=$ & $\begin{array}{l}0 \\
D\end{array}$ & $=$ & $=$ \\
\hline $\begin{array}{l}11 N 20 E 19 L 01 \\
11 N 20 E 27 C 01\end{array}$ & $\begin{array}{l}462523 N 1202209 \cdot 1 \\
462500 N 1201810.1\end{array}$ & $\begin{array}{l}\text { CELIA P JOHNSON } \\
\text { FRANK RICHES }\end{array}$ & ${ }_{H}^{H}$ & $\begin{array}{l}810 \\
775\end{array}$ & $\begin{array}{r}41 \\
125\end{array}$ & $\stackrel{O A}{A}_{0 A}$ &.-12 & $=$ & -.10 & $=$ & $\begin{array}{c}0 \\
-\end{array}$ & $=$ & $=$ \\
\hline 11 N20E27001 & $462506 \mathrm{~N} 1201839.1$ & INKLER & I & 775 & 582 & EL & $=$ & $=$ & $\because$ & -- & $=$ & -- & -- \\
\hline IINZOE.ZRPOI & $462417 N 1201902.1$ & MARY SCOTT & H & 780 & 47 & $O A$ & -- & -- & 15 & -- & D & -- & -- \\
\hline 11 N20E 31001 & $462414 \mathrm{~N} 1202225.1$ & RAMONA JAMES & H & 790 & 51 & $O A$ & 13 & $12-65$ & 10 & 7 & D & -- & -- \\
\hline 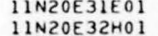 & $\begin{array}{l}4625358 N 1202255.1 \\
462356 N 1202016.1\end{array}$ & $\begin{array}{l}\text { MELVIN MILLER } \\
\text { RONE }\end{array}$ & ${ }_{H}^{H}$ & $\begin{array}{l}790 \\
780\end{array}$ & 50 & $\begin{array}{l}O A \\
O A\end{array}$ & $\begin{array}{l}14 \\
11\end{array}$ & $\begin{array}{r}12-65 \\
4-71\end{array}$ & 10 & $--^{4}$ & 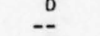 & $=$ & $=$ \\
\hline 1 INZOE $32 N 01$ & $462335 N 1201949.1$ & SADIE LONG & H & 780 & 49 & $\begin{array}{l}O A \\
O A\end{array}$ & 12 & $1-66$ & 10 & 9 & D & $=$ & $=$ \\
\hline 1 IN20E $33 \mathrm{JNOI}$ & $462339 N 1201853.1$ & USI SUGAR CO & N & 767 & 225 & $O A$ & -- & -- & 1200 & -- & -- & - & - \\
\hline $\begin{array}{l}11 \mathrm{~N} 20 \mathrm{E} 33 \mathrm{~J} 02 \\
1 \text { IN2OE } 33 \mathrm{NO} 3\end{array}$ & $\begin{array}{l}462348 N 1201856.1 \\
462325 N 1201949.1\end{array}$ & $\begin{array}{l}\text { USI SUGAR CO } \\
\text { VICTOR LADDROUT }\end{array}$ & $\underset{H}{N}$ & $\begin{array}{l}767 \\
770\end{array}$ & $\begin{array}{r}262 \\
50\end{array}$ & $\begin{array}{l}O A \\
O A\end{array}$ & $-\overline{13}$ & $2--6$ & $\begin{array}{r}1650 \\
10\end{array}$ & $\overline{13}$ & $\overline{0}$ & $=$ & $=$ \\
\hline 1 IN2OE $34 E 01$ & $462349 \mathrm{~N} 1201845.1$ & USI SUGAR CO & $\hat{N}$ & 767 & 260 & $O A$ & -- & $-\infty$ & 2300 & -- & -- & -- & - \\
\hline 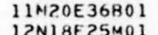 & $\begin{array}{l}462412 N 1201529.1 \\
46294201203198\end{array}$ & TOWN OF ZILLAH & $\mathrm{p}$ & $\begin{array}{r}950 \\
\end{array}$ & 281 & $O A$ & 113 & $\begin{array}{l}3-71 \\
5-62\end{array}$ & $-\overline{60}$ & $=$ & $=$ & $z$ & $=$ \\
\hline $12 \mathrm{~N} 18 E 25 M 01$ & $462954 N 1203118.1$ & HELEN WINKELMAN & I & 1030 & 303 & EL & 95 & $5-62$ & 60 & -- & & & \\
\hline $\begin{array}{l}\text { 12N1BE27G01 } \\
12 \mathrm{N1BE27HO1}\end{array}$ & $\begin{array}{l}463007 N 1203311.1 \\
463008 N 1203237.1\end{array}$ & $\begin{array}{l}\text { HANSEN FRUIT } \\
\text { HANSEN FRUIT }\end{array}$ & $\begin{array}{l}\mathrm{I} \\
\mathrm{I}\end{array}$ & $\begin{array}{l}1145 \\
1120\end{array}$ & $\begin{array}{l}1000 \\
1020\end{array}$ & $\begin{array}{l}Y A \\
Y A\end{array}$ & $\overline{230}$ & $\ddot{3-68}$ & 2100 & $\overline{310}$ & $\begin{array}{l}0 \\
D\end{array}$ & $\begin{array}{l}6 \\
4\end{array}$ & $\begin{array}{l}2320 \\
1220\end{array}$ \\
\hline 12N1BE27NOI & $462935 N 1203342.2$ & DENNIS CAFFREY & I & 1135 & 600 & $\hat{Y A}$ & 220 & $2-56$ & 400 & 78 & D & 1 & 489 \\
\hline 12N18E27P01 & $462933 N 1203238.1$ & HANSEN FRUIT & I & 1052 & 1109 & $Y A$ & 157 & $10-57$ & 850 & 66 & D & - & -- \\
\hline 12N1AE $31 R 01$ & $462842 \mathrm{~N} 1203635.1$ & RAY ST CLAIR & I & 1105 & 1573 & YA & 209 & $4-65$ & 1100 & 244 & D & 6 & 1170 \\
\hline $\begin{array}{l}\text { 12N18E332H01 } \\
12 \mathrm{N1BE} 32 \mathrm{LO} 01\end{array}$ & $\begin{array}{l}462907 N 1203511.1 \\
462854 N 1203554.1\end{array}$ & $\begin{array}{l}\text { MT ADAMS SEEO } \\
\text { RAY ST CLAIK }\end{array}$ & $\stackrel{I}{I}$ & $\begin{array}{l}1130 \\
1058\end{array}$ & $\begin{array}{l}1176 \\
1252\end{array}$ & $\begin{array}{l}Y A \\
Y A\end{array}$ & $\begin{array}{l}216 \\
158\end{array}$ & $\begin{array}{l}2-65 \\
4-64\end{array}$ & $\begin{array}{l}695 \\
220\end{array}$ & $\begin{array}{r}81 \\
119\end{array}$ & $\begin{array}{l}D \\
D\end{array}$ & $\begin{array}{r}12 \\
8\end{array}$ & 1460 \\
\hline $12 \mathrm{~N} 1 \mathrm{QE} 33 \mathrm{AAO}$ & $462930 N 1203355.1$ & HERBERT NYRERG & I & $\begin{array}{l}1185 \\
1185\end{array}$ & 953 & $O A$ & 210 & $\begin{array}{r}4-64 \\
4-69\end{array}$ & $\begin{array}{r}2200 \\
1400\end{array}$ & 126 & $\begin{array}{l}0 \\
0\end{array}$ & -8 & $25 \overline{2}$ \\
\hline $\begin{array}{l}\text { 12N18E33801 } \\
12 \mathrm{~N} 18 \mathrm{BE} 35 \mathrm{HO} 01\end{array}$ & $\begin{array}{l}462929 \mathrm{~N} 1203411.1 \\
462909 \mathrm{~N} 1203120.1\end{array}$ & $\begin{array}{l}\text { MT ADAMS SEED } \\
\text { DON PATTERSON }\end{array}$ & $\stackrel{\mathrm{I}}{\mathrm{H}}$ & $\begin{array}{r}1143 \\
952\end{array}$ & $\begin{array}{r}1091 \\
141\end{array}$ & $\begin{array}{l}Y A \\
O A\end{array}$ & 264 & $1-68$ & 1180 & 67 & -- & -8 & -- \\
\hline $12 N 19 E 29801$ & $463016 N 1202757.1$ & NO PAC RR & u & 923 & 25 & $O A$ & -- & -- & -- & -- & -- & -- & -- \\
\hline 12N19E29 & 46295 & ALBA SH & H & 920 & 73 & $O A$ & 18 & $4-63$ & 40 & 2 & 0 & -- & -- \\
\hline 12N19E29K01 & $462955 N 1202749.1$ & $\begin{array}{l}\text { MARLEY ORCHARDS } \\
\text { SECEYS }\end{array}$ & H & 918 & 305 & EL & 18 & $3-71$ & 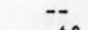 & -- & -- & -- & -- \\
\hline $\begin{array}{l}\text { 12N19E32C01 } \\
12 N 19 E 32 C 02\end{array}$ & $\begin{array}{l}46293001202808.1 \\
462929 N 1202823.1\end{array}$ & $\begin{array}{l}\text { CECIL JAMES } \\
\text { JIMMY ANDERSON }\end{array}$ & ${ }_{H}^{H}$ & $\begin{array}{l}912 \\
912\end{array}$ & $\begin{array}{l}160 \\
160\end{array}$ & $\begin{array}{l}E L \\
E L\end{array}$ & $\begin{array}{l}20 \\
20\end{array}$ & $\begin{array}{l}3-63 \\
3-63\end{array}$ & $\begin{array}{l}40 \\
40\end{array}$ & $\begin{array}{r}010 \\
10\end{array}$ & $\begin{array}{l}D \\
D\end{array}$ & $=$ & $\begin{array}{l}-- \\
--\end{array}$ \\
\hline 12N1 OE З2MO1 & $462901 N 1202842.1$ & FREO HOPTOWIT & h & 907 & 42 & $O A$ & A & $7-62$ & 10 & 2 & D & -- & -- \\
\hline 12N19E32N01 & $462841 N 1202844.1$ & RICHARD HOWARD & H & 913 & 42 & $O A$ & -- & $=-$ & 30 & - & D & - & -- \\
\hline $\begin{array}{l}\text { 12N19F33K01 } \\
12 \mathrm{~N} 19 \mathrm{EE} 35001\end{array}$ & $\begin{array}{l}462900 N 1202642.1 \\
462921 N 1202454.1\end{array}$ & $\begin{array}{l}\text { HELEN JIM } \\
\text { GLEN RASMUSSEN }\end{array}$ & $\stackrel{H}{I}$ & $\begin{array}{l}890 \\
880\end{array}$ & $\begin{array}{r}42 \\
141\end{array}$ & $\begin{array}{l}O A \\
O A\end{array}$ & $\begin{array}{r}8 \\
16\end{array}$ & $\begin{array}{l}5-62 \\
3-71\end{array}$ & $-{ }_{-}^{10}$ & $--^{9}$ & $\therefore$ & $=$ & -- \\
\hline
\end{tabular}


APPENDIX IV.--Logs of selected wells in the Toppenish Creek basin

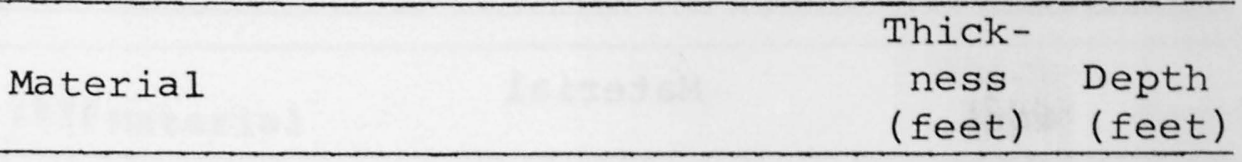

10/16-10N1. W. B. Pace, Jr. Drilled by

Bill Ludwig, 1953; deepened by Henry Bach, 1961.

Soft drilling, water at 34 and $80 \mathrm{ft}$

Rock, water at 275 and $340 \mathrm{ft}$

Rock, honeycombed-....

Rock, hard-...

Rock, broken, water-..-

Rock, hard-.......

Basalt, solid, black-1..-

Rock, broken, black-...

Rock, solid, black-.......

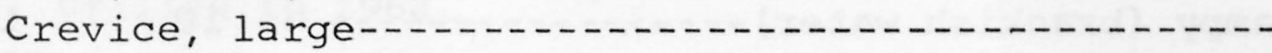

242

100

23

95

15

4

46

5

30

7
242

342

365

460

475

479

525

530

560

567

10/16-19G1. Fort Simcoe Job Corps. Drilled by Ralph Cassell, 1966.

Boulders..............................................

Gravel, cemented, some boulders (10 gal $/ \mathrm{min})$-...--

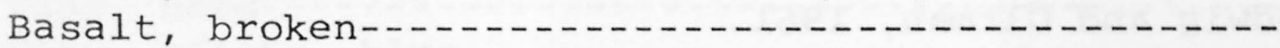

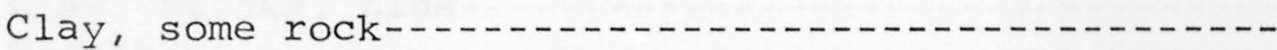

Basalt, black, water on top-...

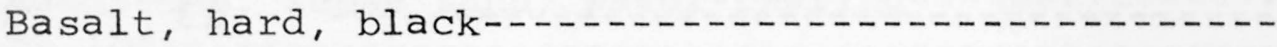

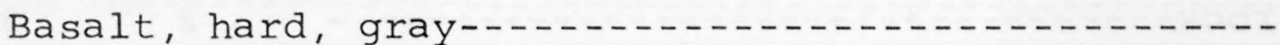

Basalt, gray-........

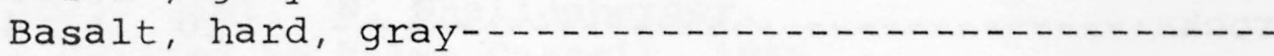

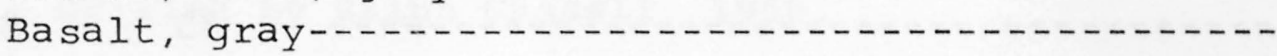

Basalt, hard, gray-n

Basalt, gray-1...

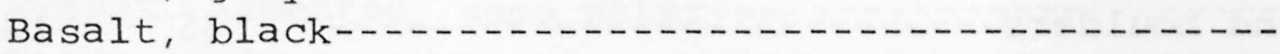

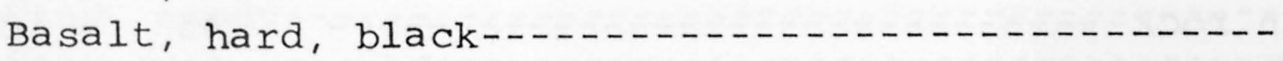

Basalt, gray--

No $\log$

$\begin{array}{rr}23 & 23 \\ 11 & 34 \\ 16 & 50 \\ 15 & 65 \\ 10 & 75 \\ 5 & 80 \\ 25 & 105 \\ 6 & 111 \\ 14 & 125 \\ 7 & 132 \\ 13 & 145 \\ 7 & 152 \\ 7 & 159 \\ 3 & 162 \\ 18 & 180 \\ 245 & 425\end{array}$


APPENDIX IV.--Logs of selected wells in the Toppenish Creek basin--Continued

\begin{tabular}{lcc}
\hline Material & $\begin{array}{c}\text { Thick- } \\
\text { ness } \\
\text { (feet) }\end{array}$ & $\begin{array}{c}\text { Depth } \\
\text { (feet) }\end{array}$ \\
\hline
\end{tabular}

10/16-23D1. Carol Lawrence.

Drilled by Henry Bach, 1963.

Soil-1...

Gravel and boulders-.....

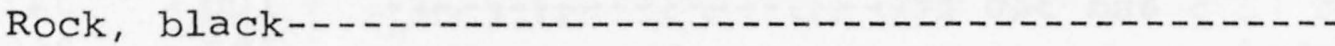

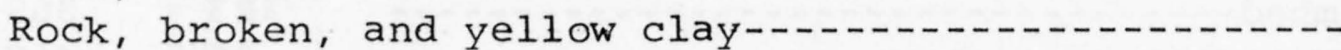

Basalt-.........

$\begin{array}{rr}1 & 1 \\ 41 & 42 \\ 9 & 51 \\ 33 & 84 \\ 47 & 131\end{array}$

10/17-6D1. Boise Cascade Co.

Drilled by John Riebe, 1969.

Soil, silty, swampy (brackish water)-_.........- 1818

Rock, decomposed, and boulders; some water-1.-.-.-- $167 \quad 185$

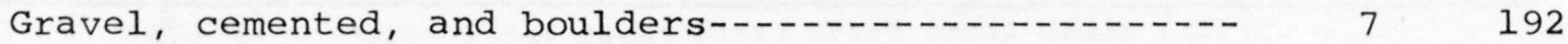

Clay, hard, brown, and boulders-.............. $31 \quad 223$

Basalt, broken, with sand, gravel and clay (water)--- 6229

Rock, decomposed, cemented gravel, clay and boulders- $13 \quad 242$

10/17-17L2. Yakima Indian Mission.

Drilled by Ludwig and Oltman, 1961.

Soil-10

15

15

Boulders-1...

13

28

Clay, and loose rock-1.-.

Boulders-............

Clay, and loose rock-1.-

Rock and clay-..-

Clay, muddy-..-...-

Rock, broken, some water-1...

Clay, gravel, and boulders-1.-.-

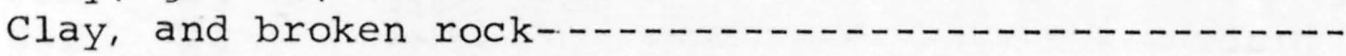

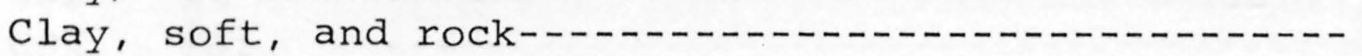

Boulders and gravel, water-bearing-_.................

Shale, soft-1...

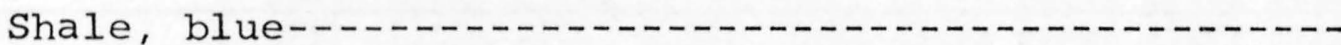

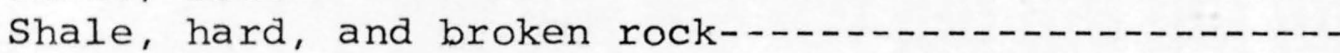

Clay, sticky, blue-1...

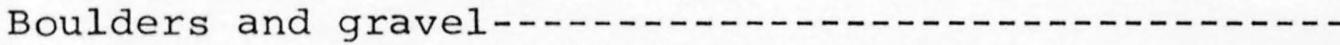

(continued)

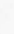
2 1 84 . 
APPENDIX IV.--Logs of selected wells in the Toppenish Creek basin--Continued

\begin{tabular}{ccc}
\hline & Thick- \\
Material & ness Depth \\
& (feet) (feet)
\end{tabular}

10/17-17L2.--Continued

Shale, gray-.....

Boulders and gravel, and a little sand and water----

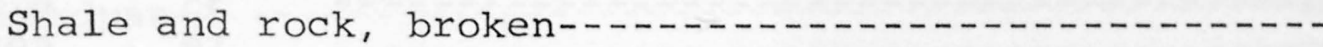

Rock, soft_......

Rock, hard-.....

Rock, water-bearing-

Rock, hard-........

$\begin{array}{rr}15 & 275 \\ 7 & 282 \\ 5 & 287 \\ 3 & 290 \\ 7 & 297 \\ 10 & 307 \\ 3 & 310\end{array}$

10/17-23L1. B. C. Dekker.

Drilled in 1962 .

Dirt-1..

13

13

Unrecorded material; water at 75 ft-......

Clay and rock-...-

79

92

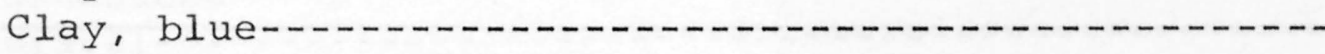

32

124

Clay, brown, and gravel; water-bearing-......

21

145

Clay and rocks--.-.-.-.-.-

30

175

Clay, hard-...-.-.-.-

33

208

Clay, sticky, blue--

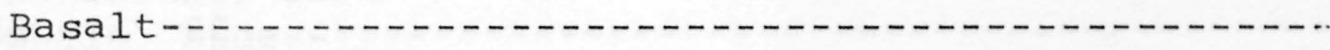

Sandstone, loose sand; water-bearing-...-.

No log-...-...-.

116

72

324

$60 \quad 456$

244

700

10/17-35B1. N. Shellenberger.

Drilled by Ralph Cassell, 1958.

Soil- - - - -

Gravel, cemented, some water

Clay, sandy--.--

Clay--- - - - - - - - -

Gravel cement-..-

Clay-- - - - - - - - - -

Sinale, blue---

Basalt-......-.

Shale, green--

Basalt

(continued)

$\begin{array}{rr}4 & 4 \\ 76 & 80 \\ 13 & 93 \\ 32 & 125 \\ 35 & 160 \\ 69 & 229 \\ 11 & 240 \\ 35 & 275 \\ 6 & 281 \\ 204 & 485\end{array}$


APPENDIX IV.--Logs of selected wells in the Toppenish Creek basin--Continued

\begin{tabular}{ccc} 
Material & $\begin{array}{c}\text { Thick- } \\
\text { ness }\end{array}$ & $\begin{array}{c}\text { Depth } \\
\text { (feet) }\end{array}$ \\
\hline
\end{tabular}

10/17-35B1.--Continued

Basalt, seamed, with clay-...- $20 \quad 505$

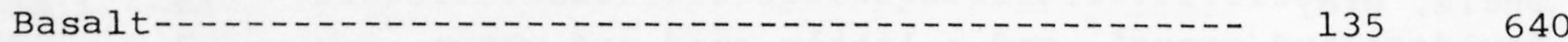

Basalt, broken-... 35675

Basalt, porous-_... $18 \quad 693$

Basalt, broken-_. 12

10/18-25D1. U.S. Geological Survey.

Drilled by U.S. Geological Survey, 1972 .

Loam, silty, clayey, brown--

Clay, silty, grayish-brown-_... $12 \quad 14$

Cobbles in matrix of silty clay-...- 317

Clay, silty, and cobbles-........................ 13

Cobbles, cemented in places-.... 32

10/19-11Hl. R. Comenout.

Drilled by Henry Bach, 1967 .

Soil-

Sand, gravel-......... 33 35

Sand, packed, and yellow clay-...... $30 \quad 65$

Sand, and gravel-_... 2

10/19-17Hl. Marie Olney.

Drilled by Henry Bach, 1967 .

Soil-_.

Sand and gravel-.... $35 \quad 39$

Sand, hard-packed-_..-

Sand, silty, fine-...... $17 \quad 71$

Sand, coarse-...... 45 
APPENDIX IV.--Logs of selected wells in the Toppenish Creek basin--Continued

\begin{tabular}{|c|c|c|}
\hline Material & $\begin{array}{c}\text { Thick- } \\
\text { ness } \\
\text { (feet) }\end{array}$ & $\begin{array}{l}\text { Depth } \\
\text { (feet) }\end{array}$ \\
\hline $\begin{array}{l}\text { 10/19-30Rl. Viola O'Neil. } \\
\text { Drilled by N. C. Jannesen Co, }\end{array}$ & & \\
\hline Soil-n--n- - - - & 4 & 4 \\
\hline Hardpan--n- & 26 & 30 \\
\hline Gravel-n- & 25 & 55 \\
\hline Shale, soft-n- & 195 & 250 \\
\hline Soapstone, yellow & 20 & 270 \\
\hline Clay, yellow & 10 & 280 \\
\hline Sandstone, gray-n-n & 25 & 305 \\
\hline Gravel-n- & 30 & 335 \\
\hline Shale, blue-n-n- & 60 & 395 \\
\hline Shale, soft-n- & 80 & 475 \\
\hline 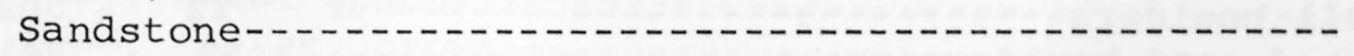 & 10 & 485 \\
\hline Shale, soft-n- & 20 & 505 \\
\hline Shale, gray---n-n-n-n & 15 & 520 \\
\hline 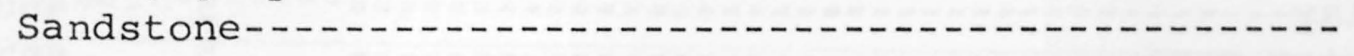 & 5 & 525 \\
\hline Gravel------ & 10 & 535 \\
\hline 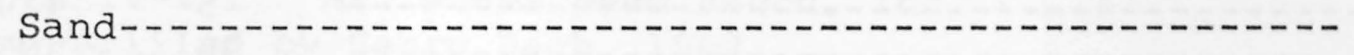 & 20 & 555 \\
\hline Shale, brown & 4 & 559 \\
\hline Shale, soft-n-n-n-n-n & 16 & 575 \\
\hline Sandstone, dark & 15 & 590 \\
\hline Shale, blue-n- & 12 & 602 \\
\hline Shale, brown-..- & 3 & 605 \\
\hline Shale, blue-n- & 35 & 640 \\
\hline 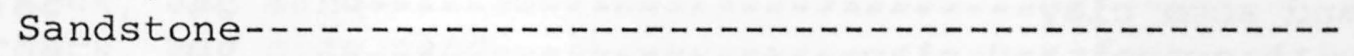 & 25 & 665 \\
\hline Shale, and fine sand-n- & 20 & 685 \\
\hline Sandstone, Iime sealer- & 30 & 715 \\
\hline
\end{tabular}

10/20-3M2. City of Toppenish.

Drilled by A. A. Durand, 1946.

Soil-0.-10

Gravel-1..-

Gravel and clay-..-

Gravel, coarse--

Gravel and clay-...

Gravel-...-

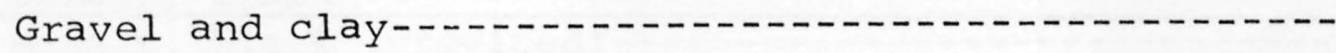

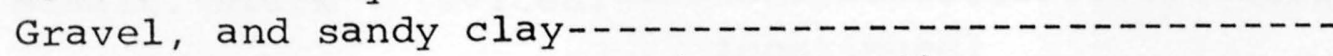

(continued)

$\begin{array}{rr}2 & 2 \\ 40 & 42 \\ 5 & 47 \\ 5 & 52 \\ 5 & 57 \\ 7 & 64 \\ 27 & 91 \\ 20 & 111\end{array}$




\section{APPENDIX IV.--Logs of selected wells in the Toppenish Creek basin--Continued}

$\begin{array}{ccc} & \text { Thick- } \\ \text { Material } & \text { ness } & \text { Depth } \\ & \text { (feet) (feet) }\end{array}$

10/20-3M2.--Continued

Gravel, coarse--Gravel, and sandy clay Gravel and sand

Gravel, and sandy clay-..... Gravel, coarse-Boulders and clay
Clay, sandy Clay, sandy-Sand, hard, and sandstoneClay, pink-1and and Clay, and small boulders--.-.-. Gravel, cemented, and boulders..... Sand, clay, and gravel-... Gravel and clay--

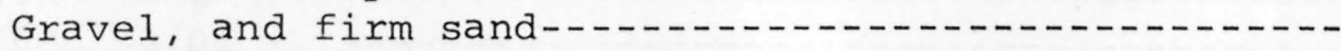
Sand, firm--.-.-Clay, yellowSand and gravel--.-Gravel, cemented, hard, and sand-..... Gravel, and firm sand-...... Gravel, cemented, hard, and sand-... Clay, yellow-... Sand, firm, and some claySand, hard, with gravel and clay-..... Sand and gravel-.... Clay, yellow-.... Clay, blue, with some rock-... Sand, firm, and a little clayClay, blue-..... Sand, firm, and gravelClay, blue-... Clay, blue, and gravel-... Gravel, and fine sand-... Sand, gray-...Sand and gravel-...

\begin{tabular}{rr}
5 & 116 \\
21 & 137 \\
7 & 144 \\
9 & 153 \\
7 & 160 \\
60 & 220 \\
35 & 255 \\
5 & 260 \\
25 & 285 \\
5 & 290 \\
12 & 302 \\
39 & 341 \\
116 & 457 \\
3 & 460 \\
5 & 465 \\
5 & 470 \\
35 & 505 \\
12 & 517 \\
13 & 530 \\
15 & 545 \\
5 & 550 \\
13 & 563 \\
24 & 587 \\
20 & 607 \\
3 & 610 \\
10 & 620 \\
10 & 630 \\
80 & 710 \\
30 & 740 \\
2 & 742 \\
3 & 745 \\
30 & 775 \\
1 & 776 \\
6 & 782 \\
18 & 800 \\
& \\
\hline 5 &
\end{tabular}


APPENDIX IV .--Logs of selected wells in the Toppenish Creek basin--Continued

\begin{tabular}{|c|c|c|}
\hline Material & $\begin{array}{c}\text { Thick- } \\
\text { ness } \\
\text { (feet) }\end{array}$ & $\begin{array}{l}\text { Depth } \\
\text { (feet) }\end{array}$ \\
\hline $\begin{array}{l}\text { 11/16-25Gl. Bill Blodgett. } \\
\text { Drilled by Henry Bach, } 1971 .\end{array}$ & & \\
\hline Soild-- & 5 & 5 \\
\hline Gravel, cemented- & 130 & 135 \\
\hline Clay, sticky, gray & 43 & 178 \\
\hline Sand and rock, water-bearing & 12 & 190 \\
\hline Clay, hard, and sand & 70 & 260 \\
\hline Sand and rock, water-bearing & 18 & 278 \\
\hline Clay, soft, yellow & 24 & 302 \\
\hline Clay, brown- & 18 & 320 \\
\hline Clay, sticky, yellow & 40 & 360 \\
\hline Clay, brown & 40 & 400 \\
\hline Clay, hard, green & 10 & 410 \\
\hline Sand, coarse, brown & 5 & 415 \\
\hline Sand, coarse, green & 103 & 518 \\
\hline Basalt-n- & 7 & 525 \\
\hline
\end{tabular}

11/17-1F1. Mt. Adams Seed Ranch, Inc.

Drilled by Henry Bach, 1962 .

Soil

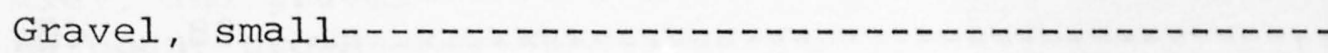

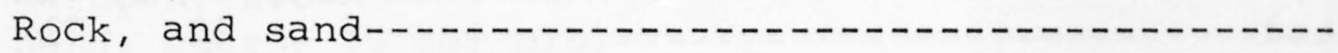

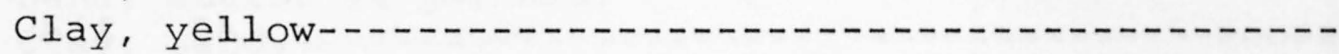

Rock, and sand-------n---

Rock, and gray sand--.--

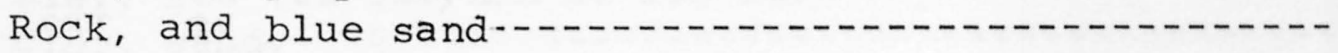

Clay, sticky, blue------------------------------

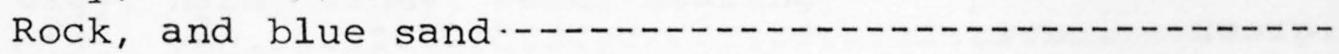

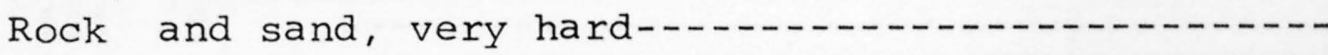

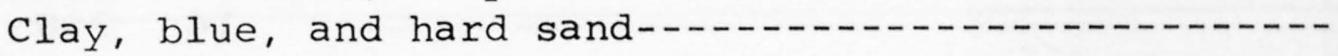

Rock and sand, very hard-.--

Sand and clay, blue----------

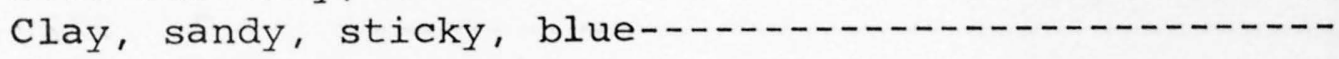

Sand, heaving-----

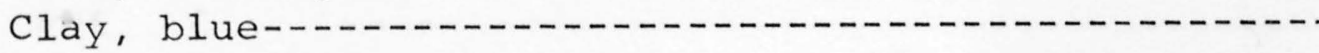

Basalt, gray--------

Basalt, black--------n-

Basalt, black (creviced) -

(continued)

$\begin{array}{rr}14 & 14 \\ 2 & 16 \\ 23 & 39 \\ 71 & 110 \\ 35 & 145 \\ 43 & 188 \\ 136 & 324 \\ 8 & 332 \\ 125 & 457 \\ 27 & 484 \\ 5 & 489 \\ 12 & 501 \\ 16 & 517 \\ 10 & 527 \\ 28 & 555 \\ 48 & 603 \\ 56 & 659 \\ 100 & 759 \\ 5 & 764\end{array}$


APPENDIX IV .--Logs of selected wells in the Toppenish Creek basin--Continued

$\begin{array}{ccc}\text { Material } & \text { Thick- } \\ & \text { ness } & \text { Depth } \\ \text { (feet) (feet) }\end{array}$

11/17-1F1.--Continued

Basalt, hard, black-...-

Basalt, black (creviced)

Basalt, black-.-.-.

Basalt, black (creviced)

Rock, black-.....

Rock, black (creviced)

Rock, black--.--

Basalt, black-.......

Basalt, broken, black-...

Shale, sandy, broken--...

Basalt, broken, black-...

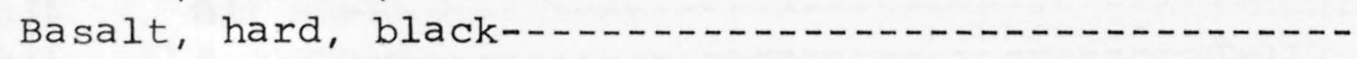

Basalt, broken, black-..

$\begin{array}{rr}107 & 871 \\ 4 & 875 \\ 6 & 881 \\ 6 & 887 \\ 5 & 892 \\ 10 & 902 \\ 84 & 986 \\ 76 & 1,062 \\ 45 & 1,107 \\ 8 & 1,115 \\ 29 & 1,144 \\ 1 & 1,145 \\ 29 & 1,174\end{array}$

11/17-17P1. C. and H. Stephenson.

Drilled by Henry Bach, 1963.

Topsoil and small gravel-

Gravel--.----

Clay, brown-...

Gravel, cemented--

Clay and sandstone--...

Gravel, water-bearing-

Clay and sandstone--

Clay, brown-...

Clay, sandy--

Clay, sticky, green-1...

Clay, gray--

Clay, brown-....

Clay, green--..-

Clay, brown--

Clay, gray-...

Clay, green--

Clay, brown--.-.-.-

Clay, sandy, green--

Sand--.-

Basalt, black-.-

Basalt, broken, black-..

Basalt, brown-

(continued)

$\begin{array}{rr}18 & 18 \\ 2 & 20 \\ 28 & 48 \\ 23 & 71 \\ 43 & 114 \\ 2 & 116 \\ 43 & 159 \\ 28 & 187 \\ 14 & 201 \\ 15 & 216 \\ 8 & 224 \\ 14 & 238 \\ 19 & 257 \\ 8 & 265 \\ 7 & 272 \\ 34 & 306 \\ 3 & 309 \\ 18 & 327 \\ 4 & 331 \\ 12 & 343 \\ 39 & 382 \\ 4 & 386\end{array}$


APPENDIX IV.--Logs of selected wells in the Toppenish Creek basin--Continued

\begin{tabular}{ccc}
\hline & Thick- \\
Material & ness Depth \\
& (feet) (feet) \\
\hline
\end{tabular}

11/17-17P1.--Continued

Basalt, black-... $16 \quad 402$

Basalt, broken, black, water-bearing-_-_.-. $32 \quad 434$

Basalt, broken, caving, black-..-..- 139573

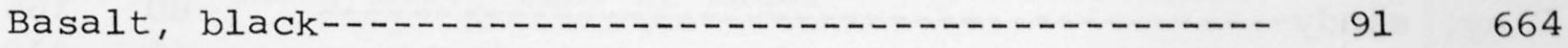

Basalt, broken, black-..- $26 \quad 690$

Basalt, black-... 999

Basalt, càving, black-1 12711

Clay, green and gray-...- 84795

Basalt, black-... 12807

Basalt, honeycombed, black-188 995

11/17-32L2. Michael Lewis.

Drilled by C. Bach, 1972 .

Soil-

Hardpan--------

$15 \quad 15$

520

Clay, sandy--.-- $11 \quad 31$

Hardpan, sandy, green-_. 78

Hardpan, brown- 75

Clay, and gravel-_... 50

Hardpan, brown-.. $22 \quad 72$

Sand, coarse (4 gal/min)

Clay, sandy-..- 60

Clay, brown-.... $45 \quad 125$

Clay, red (29 gal/min at $135 \mathrm{ft})$

Clay, sandy-..... $30 \quad 185$

Clay, hard, sandy, water-bearing-............... 10195

Clay, red-............... 20215 
APPENDIX IV .--Logs of selected wells in the Toppenish Creek basin--Continued

\begin{tabular}{ccc}
\hline & Thick- \\
Material & ness & Depth \\
& (feet) (feet) \\
\hline
\end{tabular}

11/18-17B1. Conrad Hert. Drilled in 1930.

Dirt--

Sand, dirty-..-

$\begin{array}{rr}30 & 30 \\ 30 & 60 \\ 25 & 85 \\ 80 & 165 \\ 65 & 230 \\ 35 & 265 \\ 8 & 273 \\ 33 & 306 \\ 30 & 336 \\ 34 & 370 \\ 25 & 395 \\ 29 & 424 \\ 5 & 429 \\ 96 & 525 \\ 20 & 545 \\ 20 & 565 \\ 60 & 625\end{array}$

Clay, rocky--.--

Clay, sandy--.-.-.-

Rock, broken, and clay-...

Clay, tough, gray--...-

Soapstone, brown--....

Sandstone, brown-.....

Clay, sandy, brown--...-

Sandstone, gray-

Clay, sticky, blue-..-.

Saridstone, blue---

Sand, loose-.....

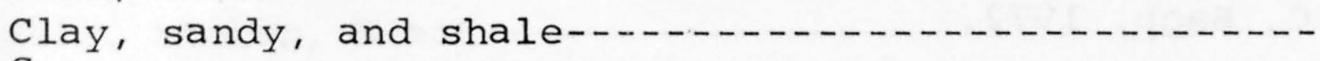

Clay, sticky, brown-.....

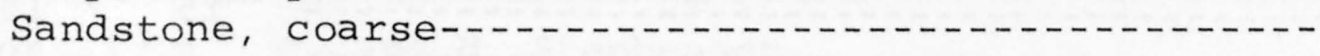

Shale, and clay with sand streaks-.-...

11/18-34P1. C. P. St. Marx.

Soil-

Gravel, coarse-....

Boulders-...-

Clay-.-.

Sandstone--

Boulders and clay-....

Sandstone-1.-

Sand-- -

Clay--.-- - - - - - - -

Clay and sand-.-.-.

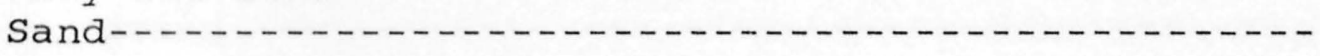

Shale, soft, loose-....

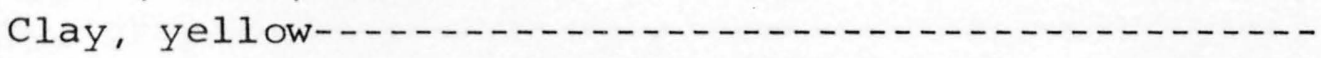

Shale, blue----

Sandstone, hard-..-

Gravel-....-

Shale-...........-.

Sand, some water

(continued)

$\begin{array}{rr}3 & 3 \\ 123 & 126 \\ 6 & 132 \\ 4 & 136 \\ 15 & 151 \\ 14 & 165 \\ 90 & 255 \\ 4 & 259 \\ 50 & 309 \\ 43 & 352 \\ 5 & 357 \\ 50 & 407 \\ 15 & 422 \\ 40 & 462 \\ 6 & 468 \\ 9 & 477 \\ 15 & 492 \\ 5 & 497\end{array}$


APPENDIX IV.--Logs of selected wells in the Toppenish Creek basin--Continued

\begin{tabular}{cc}
\hline & Thick- \\
Material & ness Depth \\
& (feet) (feet) \\
\hline
\end{tabular}

11/18-34P1.--Continued

Sand and rock-..-

Sand, more water-..........

Sand and rock, heavy flow of water.......

$6 \quad 503$

$4 \quad 507$

$5 \quad 512$

11/19-10B1. Yakima Tribe.

Drilled by Smith \& Son, 1969.

Sand, compact, and gravel with cobbles-......... $5 \quad 5$

Sand, cemented, and gravel with cobbles-.....

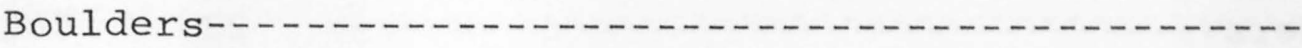

Sand, and gravel, with cemented layers-......

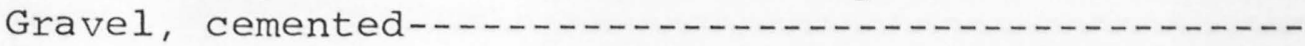

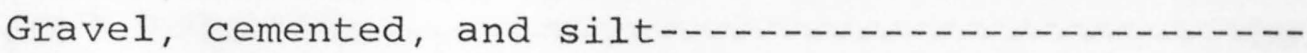

Sand, cemented, and gravel-

Sand, compact, with gravel and clay-......

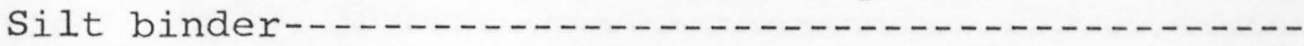

Sand, cemented, and gravel-.....

Sand, and gravel, with clay binder...............

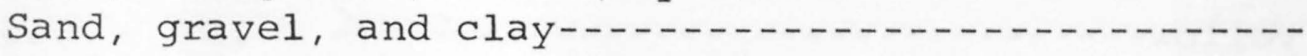

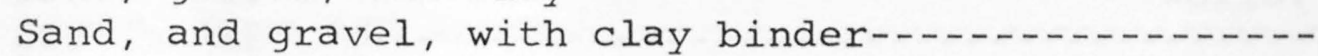

Clay, sticky, brown-....

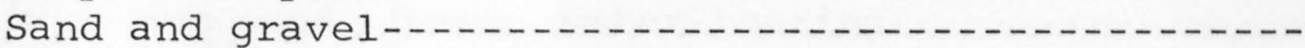

Sand, and gravel, with clay binder.......

Clay, sticky, brown, and sand and gravel-..-...-.-

Clay, blue-...

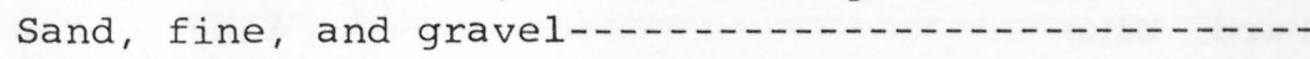

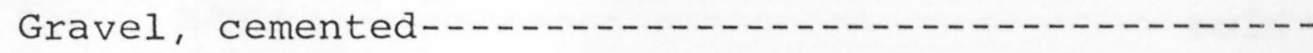

Sand, fine, with bits of shale or clay-.........-

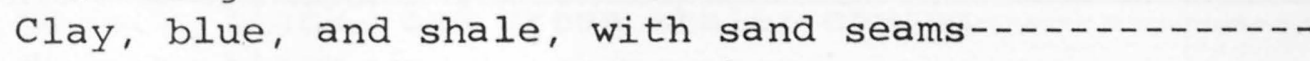

Sand, and gravel, water-bearing-....... 
APPENDIX IV.--Logs of selected wells in the Toppenish Creek basin--Continued

\begin{tabular}{ccc}
\hline Material & Thick- \\
& ness & Depth \\
(feet) & (feet) \\
\hline
\end{tabular}

11/19-15Al. City of Wapato.

Drilled by $\mathrm{N}$. C. Jannesen Co., 1946.

Grave 1-

36

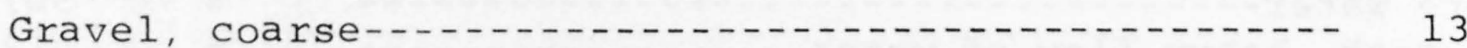

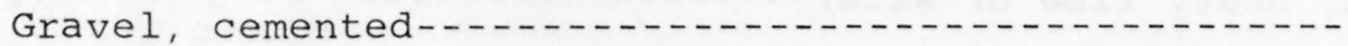

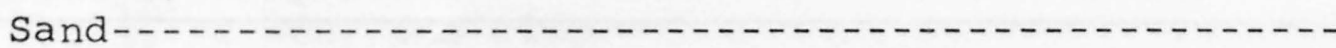

Gravel, cemented--

Gravel, and loose boulders, water-bearing-........

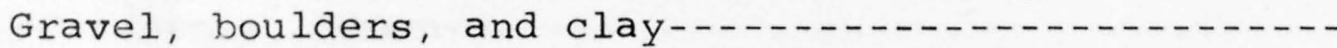

Clay and boulders-.........

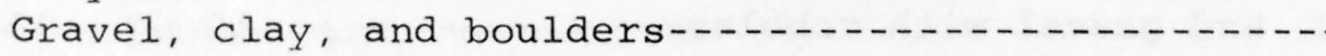

Clay and boulders

Gravel, cemented-...

Clay, yellow--.-.-.-.-

Gravel, cemented

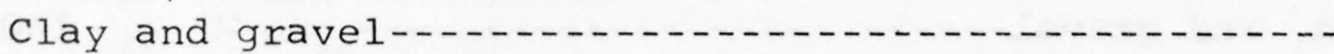

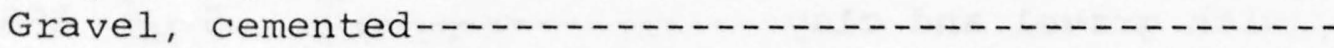

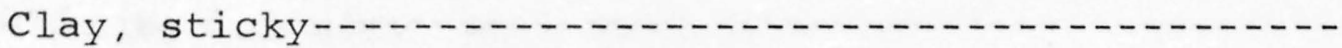

Gravel, cemented

Clay, sticky-..-...-

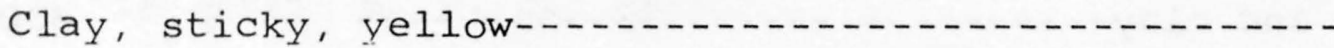

Clay, sandy-..-

Clay, sticky-.-.

Sand, loose-.......

Sand, brown, and gravel-...

Sand, brown-.....

Clay, yellow--.-

Clay, blue-

Sand, blue, water-bearing-...

Shale, sandy, hard, blue-.....

Shale, sticky, blue-...

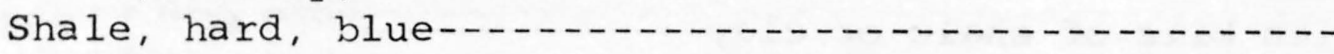

Sand, loose, gray-...
16

2

102

12

28

36

18

23

86

5

48

8

13

6

38

35

15

15

4

15

20

17

11

34

49

125

137
36

49

65

67

169

181

209

245

263

286

372

377

425

433

446

452

490

525

540

555

559

574

594

611

622

656

705

830

967

973

$2 \quad 975$ 
APPENDIX IV.--Logs of selected wells in the Toppenish Creek basin--Continued

\begin{tabular}{ccc}
\hline & Thick- \\
Material & ness Depth \\
& (feet) (feet) \\
\hline
\end{tabular}

11/19-21Q2. Lorene Sohappy.

Drilled by Henry Bach, 1966.

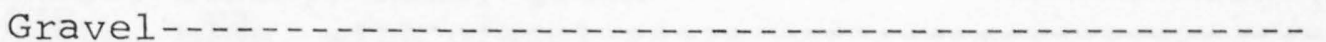

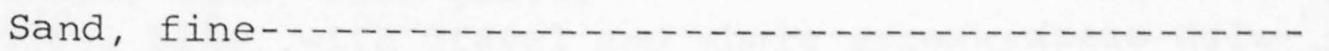

20

20

Sand, coarse, and gravel

12/18-27Hl. Hansen Fruit Co.

Drilled by Dilley Drilling Co., J.968.

Soil-1-1-

$\begin{array}{rr}8 & 8 \\ 10 & 18 \\ 47 & 65 \\ 7 & 72 \\ 43 & 115 \\ 20 & 135 \\ 20 & 155 \\ 20 & 175 \\ 15 & 190 \\ 20 & 210 \\ 10 & 220 \\ 13 & 233 \\ 12 & 245 \\ 8 & 253 \\ 21 & 274 \\ 6 & 280 \\ 15 & 295 \\ 27 & 322 \\ 8 & 330 \\ 24 & 354 \\ 21 & 375 \\ 189 & 564 \\ 11 & 575 \\ 2 & 577 \\ 5 & 582 \\ 5 & 587 \\ 3 & 590 \\ 34 & 624 \\ 16 & 640 \\ 110 & 750\end{array}$

(continued) 
APPENDIX IV.--Logs of selected wells in the Toppenish Creek basin--Continued

Material $\begin{array}{cc}\text { Thick- } \\ \text { ness } \\ \text { (feet) }\end{array} \quad \begin{gathered}\text { Depth } \\ \text { (feet) }\end{gathered}$

12/18-27H1.--Continued

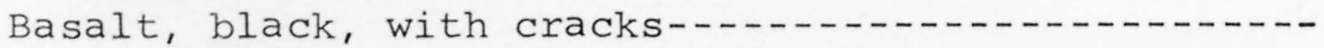

$\begin{array}{rr}3 & 753 \\ 57 & 810 \\ 3 & 813 \\ 13 & 826 \\ 25 & 851 \\ 5 & 856 \\ 25 & 881 \\ 14 & 895 \\ 1 & 896 \\ 9 & 905 \\ 33 & 938 \\ 4 & 942 \\ 5 & 947 \\ 11 & 958 \\ 25 & 983 \\ 7 & 990 \\ 1 & 991 \\ 10 & 1,001 \\ 17 & 1,018 \\ 2 & 1,020\end{array}$

Basalt, black-..-

Basalt, black, with crack

Basalt, black-....-.-

Clay, blue, and black basalt

Basalt, black-.-.-.-.-.

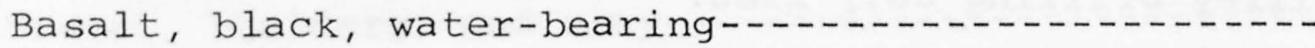

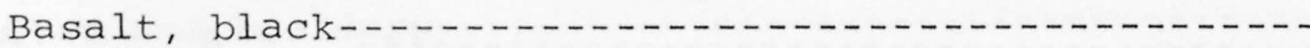

Basalt, black, few cuttings, water-bearing-.-.-.-.

Basalt, black- gray-

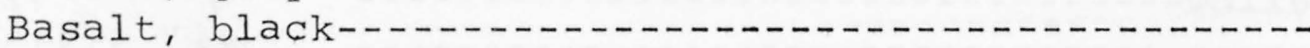

Few cuttings, water clear.....

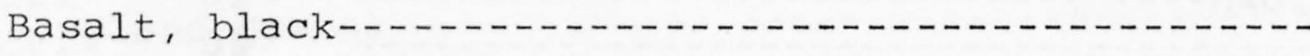

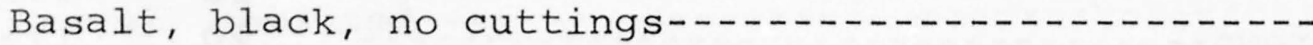

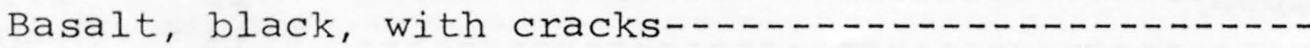

Basalt, black-.......

No cuttings, water clear-

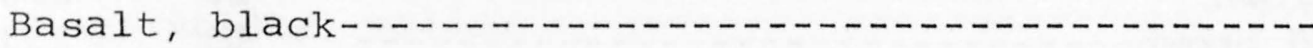

1,020

12/18-32Ll. Ray St. Clair.

Drilled by Ralph Cassel, 1964.

Topsoil-.............

Sand, clay, and yellow shale

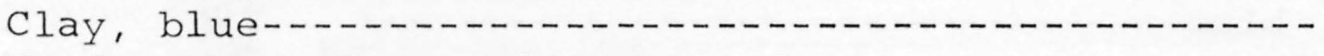

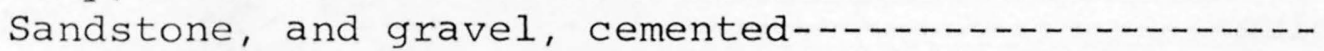

Rock and gravel, cemented-.....................

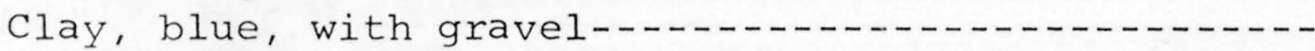

Clay, blue--------

Clay, blue, with sand-...-

$10 \quad 225$

Sand, compacted-.....

$15 \quad 240$

Clay, blue-.-.-.-.-...-.

10

250

Shale, hard, with gravel-..-.-.

Clay, green, with shale-n-...

Shale, hard, with gravel-...-

clay, green, with shale-....

$70 \quad 335$

$5 \quad 340$

$45 \quad 385$

(continued) 
APPENDIX IV.--Logs of selected wells in the Toppenish Creek basin--Continued

\begin{tabular}{ccc}
\hline & Thick- \\
Material & ness Depth \\
& (feet) (feet)
\end{tabular}

12/18-32L1.--Continued

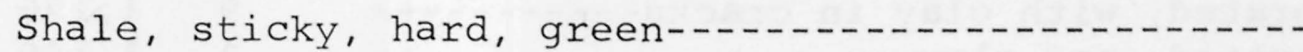

25

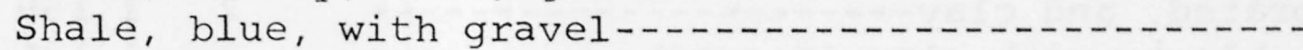

Clay, blue, with gravel and shale streaks-..-...-.-

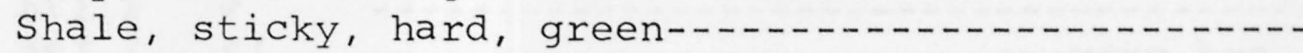

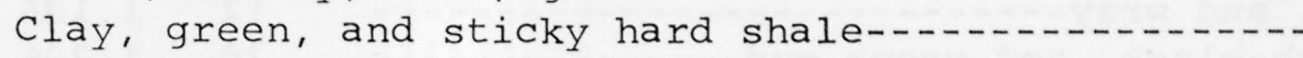

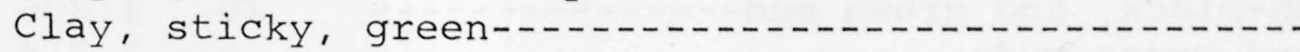

Sand, runny-..-

Clay, green-.......

Sandstone and sand formation-...

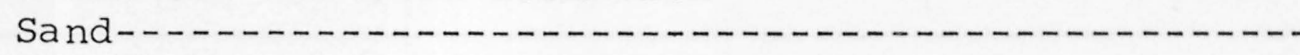

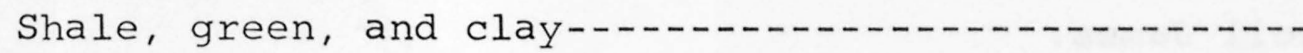

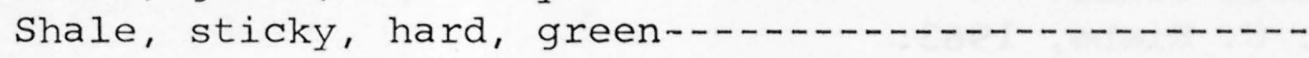

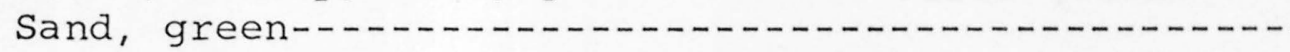

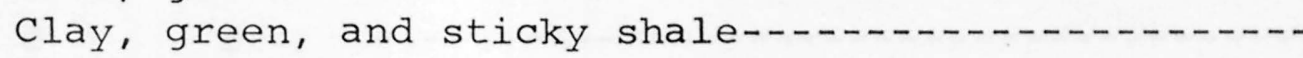

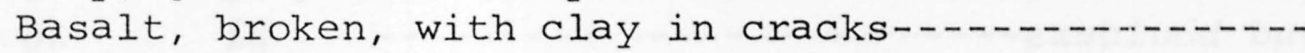

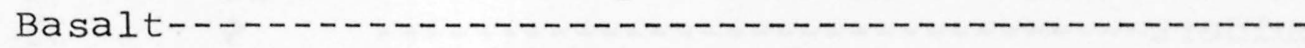

Basalt, gray-..........

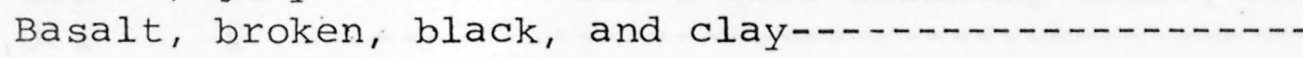

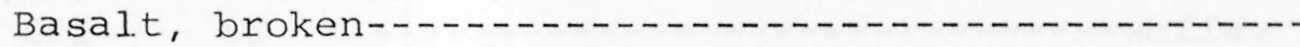

Shale, and basalt, deteriorated-...

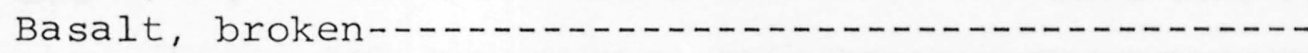

Basalt, broken, deteriorated--..-.-.-.

Basalt, broken, deteriorated, and clay-..-...-.

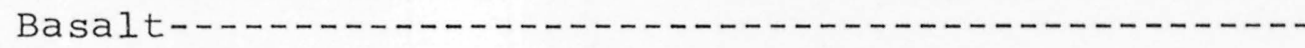

Basalt, gray-----.---.--

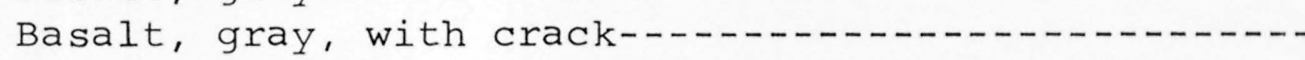

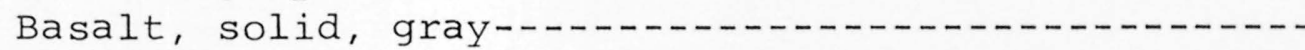

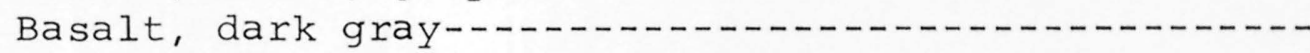

Basalt, solid, gray-

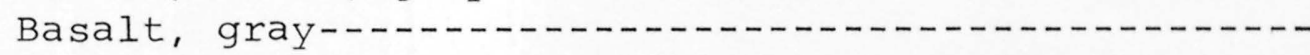

Basalt, black-...-...-

Basalt, gray--.-.-.-.

Basalt, gray and black-..

Basalt, black-.-.-.-.

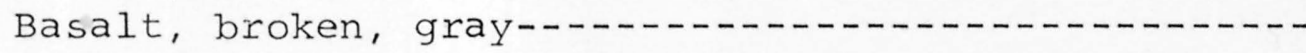

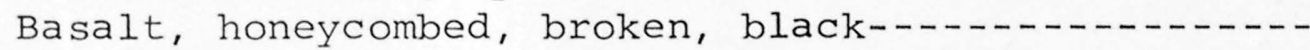

Basalt, broken, black-....

Basalt, hard, gray--

Basalt, black-..-...-.

(continued)
20

$40 \quad 470$

$25 \quad 495$

$15 \quad 510$

$2 \quad 512$

$8 \quad 520$

$5 \quad 525$

$31 \quad 556$

$19 \quad 575$

$25 \quad 600$

$8 \quad 608$

$10 \quad 618$

$22 \quad 640$

$2 \quad 642$

$8 \quad 650$

$30 \quad 680$

$22 \quad 702$

$13 \quad 715$

$15 \quad 730$

11741

19760

$22 \quad 782$

$40 \quad 822$

$20 \quad 842$

$2 \quad 844$

$14 \quad 858$

$10 \quad 868$

25893

22915

$20 \quad 935$

751,010

81,018

271,045

451,090

121,102

201,122

231,145

21,147 
APPENDIX IV .--Logs of selected wells in the Toppenish Creek basin--Continued

\begin{tabular}{ccc}
\hline Material & Thick- \\
ness & Depth \\
(feet) (feet)
\end{tabular}

\section{2/18-32L1.--Continued}

Basalt, deteriorated, with clay in cracks-.-...-.-

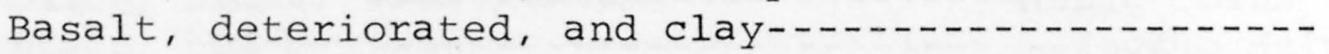

Basalt, broken, blocky with clay in cracks-.......

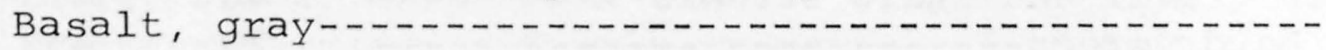

Basalt, coarse, and gray- Basalt, creenish-black, and green mud

Basalt, gray, and green mud-...

Basalt, broken, black, and clay
Basalt, solid, black

$\begin{array}{rr}9 & 1,156 \\ 2 & 1,158 \\ 7 & 1,165 \\ 9 & 1,174 \\ 12 & 1,186 \\ 20 & 1,206 \\ 8 & 1,214 \\ 26 & 1,240 \\ 12 & 1,252\end{array}$

12/19-32Cl. Cecil James.

Drilled by J. C. Riebe, 1963.

Soil, rocky----

Sand, gravel, and boulders-

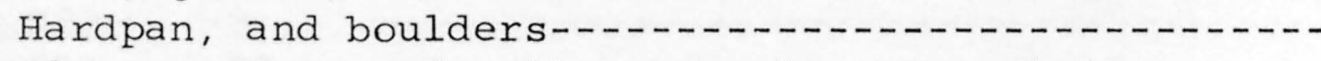

Clay, rotten, and yellow granular clay shale------

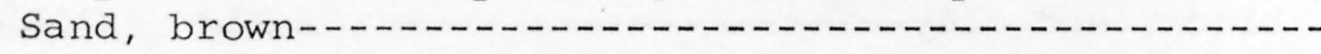

Clay, granular, yellow-

$\begin{array}{rr}5 & 5 \\ 21 & 26 \\ 9 & 35 \\ 93 & 128 \\ 2 & 130 \\ 23 & 153 \\ 7 & 160\end{array}$

Clay, dark gray, and sand- 